

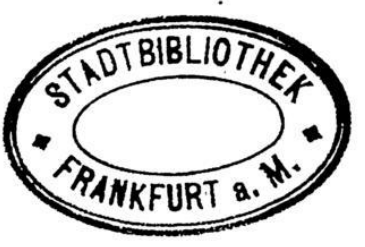




\section{THE JOURNAL OF A JEWISH TRAVELLER}




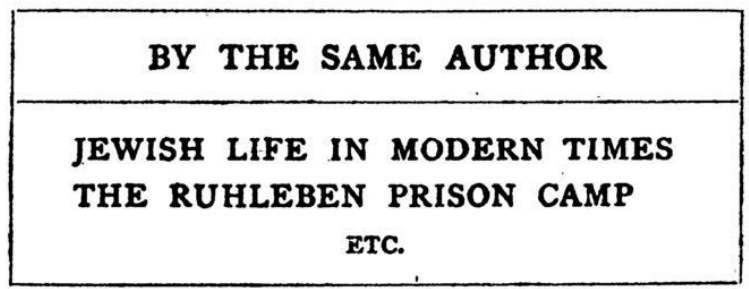




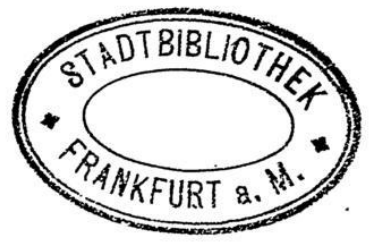




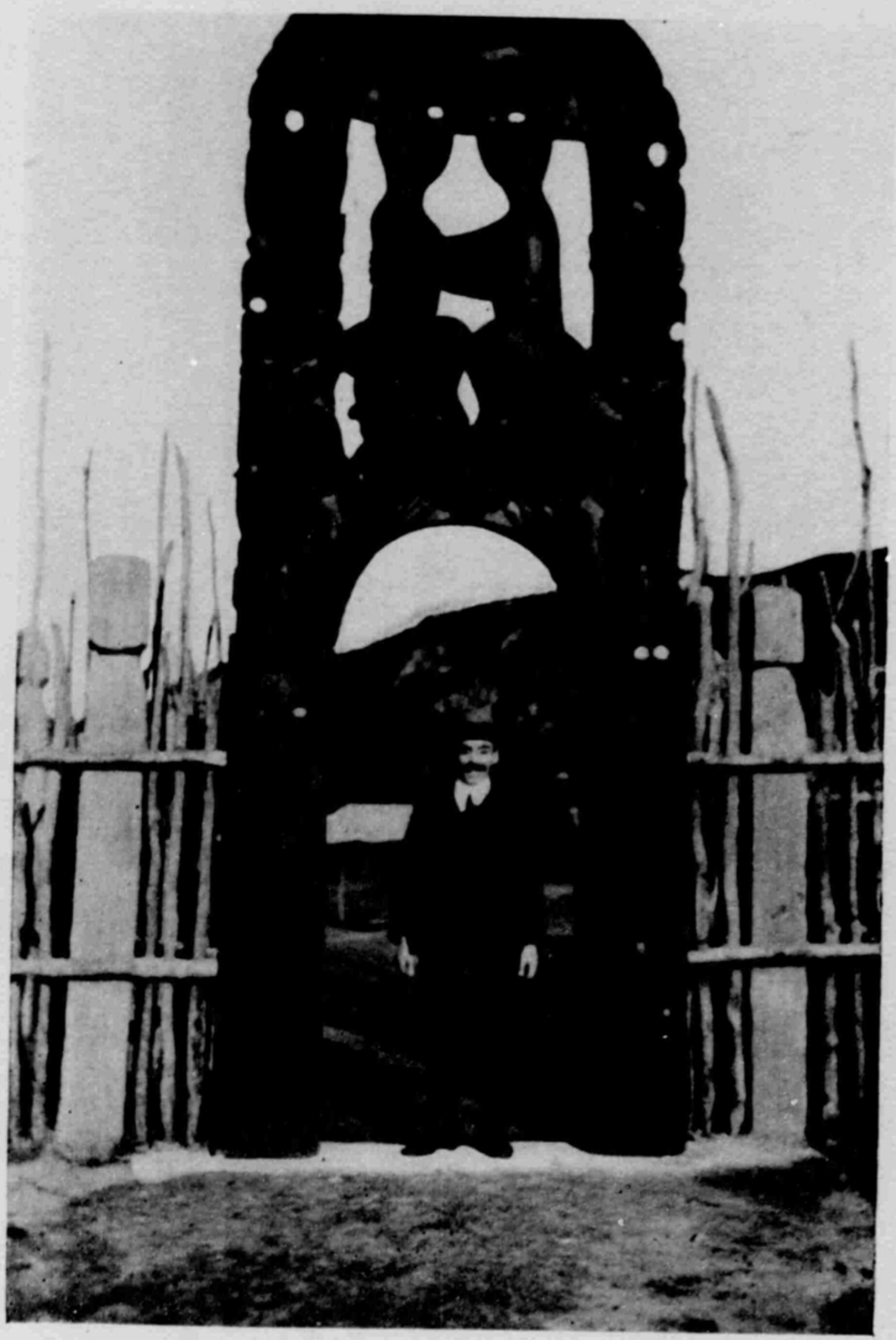

ENTRANCE TO MAORI MODEI. CAMP, NEAK ROTORUA (N.Z.). 


\section{THE JOURNAL OF A} JEWISH TRAVELLER BY ISRAEL COHEN WITH THIRTY-ONE ILLUSTRATIONS FROM PHOTOGRAPHS AND A MAP

\section{LONDON}

JOHN LANE THE BODLEY HEAD LIMITED

$$
\begin{aligned}
& 344 . \\
& 4760
\end{aligned}
$$


First Published in 1925

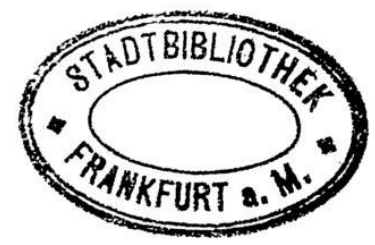

$52 / 172 \times 2$

Made and Printed in Great Britain at

The Mayflower Press, Plymouth. William Brendon \& Son, Led. 
To

MY WIFE 
As a shepherd seeketh out his flock in the day that he is among his sheep that are scattered, so will I seek out My sheep; and I will deliver them out of all places whither they have been scattered in the day of clouds and thick darkness. And I will bring them out from the peoples, and gather them from the countries, and will bring them into their own land; and I will feed them upon the mountains of Israel, by the strearns, and in all the habitable places of the country.

EzEKIEL XXXIV. 12-13.

Wand'ring from clime to clime, observant strayed, Their manners noted, and their states surveyed.

Popz's " ODYsSEy." 


\section{PREFACE}

7 HIS is the story of a pilgrimage that was undertaken between the spring of 1920 and the spring of I92I to the Jewish communities of

1 Australasia, India and the Far East. It was the first journey of its kind ever made by a Jew to the settlements of Israel in those far-off regions, and its impelling cause was an event of unique significance in the history of the Jewish people. For its purpose was to expound the import of the Balfour Declaration, that pregnant creation of the Great War, and to invoke material support for its practical realization. In the pursuit of this exacting task I was able to observe and study the conditions of the various Jewries in which I sojourned, communities of which comparatively little is known but which present a wealth of interest both to those who are curious about the vicissitudes of the Jewish people as well as to the student of contemporary civilization. In the course of a track of thirty thousand miles I noted repeated illustrations of the phenomenon so familiar in the Western world, that whilst the Jews are inevitably influenced in many ways by their environment, they are nevertheless strong and creative enough to impose upon it an impress of their own. Whether in the British dominions of Australia and New Zealand, the Crown colonies of Hongkong and Singapore, the Oriental countries of China and Japan, Java and India, or the cosmopolitan cities of Shanghai and Manila, the Jews have rendered no small service to the cause of progress in the varied domains of pioneer colonization, international commerce and good government. But devoted though they are to their native or adopted vii 
land, they cherish, for the most part, a deep and inextinguishable sentiment for the cradle of their nation, as manifested in their response to the mission it was my honour to discharge.

It was from the Land of Israel that I set out on my pilgrimage, in order to acquire the knowledge, the local colour and the inspiration wherewith to stimulate and perchance to fire my expectant audiences; and it was there, after a space of nine months, that my journeyings came to a close. The wonderful panorama of the world, from the Red Sea to the Yellow Sea, from Manchuria to the Antipodes, that I witnessed in the interval; the succession of adventures and experiences through which I passed, the impressions, reflections and emotions aroused by the places that I visited and the people with whom I spoke, the characters, oddities and freaks of fortune upon which I chanced, the instances of faith and self-sacrifice, of prosperity and suffering, of humour and pathos, even of doubt and disillusion, that chequered my path-these I have sought to portray with all fidelity as a contribution to the study of the destinies of Jewry.

I. C.

December, 1924. 


\title{
CONTENTS
}

\author{
CHAPTER I
}

THE PIONEERS' PILGRIMAGE

From Trieste to Alexandria-Youthful pioneers-Survivors of the Lemberg pogrom-Arrested by Czechs-A Hebrew visaA girl enthusiast-The Pinsk outrage-A pre-war settlerSongs of exile and redemption .

\section{CHAPTER II}

IMPRESSIONS OF JERUSALEM

Through the Sinai Desert-The Ludd junction-The situation of Jerusalem-In quest of a Jewish shrine-The Wailing WallLack of a Jewish impress-A natural history museum-The

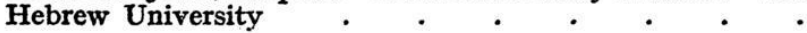

\section{CHAPTER III}

THE JUDEAN COLONIES

The oases of Palestine-The road to Petach Tikvah-A selfgoverning community - Rishon-le-Zion - Imprisoned by Djemal Pasha-The origin of the Arab agitation- " Lovers' Iane"-A tour through wine-cellars-A Christmas celebration underground-Mr. Chesterton and facts-Football at Nes-Zionah-The plantations of Rehoboth-An inequitable fiscal system .

\section{CHAPTER IV}

\section{FROM PORT SAID TO FREMANTLE}

Through Suez Canal-Memories of the Red Sea-Weathering a monsoon-Praying for "Jews and infidels" at ColomboNews from the Cocos Islands-A message from the Rabbi of Perth.

\section{CHAPTER V}

\section{THE PERTH CAMPAIGN}

A duty on Zionist flags-A Jewish war memorial-Palestinian imigrés-The Town Hall meeting-Municipal receptionMy first appeal-The first $£$ rooo-Lunch at Parliament House-Benno Moiseiwitsch and John Lawson-A congregational ball .

$$
\text { ix }
$$




\section{CHAPTER VI}

ACROSS THE AUSTRALIAN DESERT

A welcome at Kalgoorlie-Through Nullarbor Plain-Some aborigines-An Irishman to the rescue of a German priestOther fellow-passengers-The Jews of Adelaide-Links with Sir Moses Montefiore-A Jewish Premier-Colonel Gawler •

\section{CHAPTER VII}

\section{MEMORIES OF MELBOURNE}

A popular anthem-An ex-remittance man-General Sir John Monash-" Australia will be there!"-Justice Isaacs-Canvassing contributors-The Shepparton colony-A professor's history-"Billy" Hughes . . . . . .

\section{CHAPTER VIII}

\section{EXPERIENCES IN SYDNEY}

The Montefiore brothers-Jewish politicians-The importance of harmony-At the Millions Club-At the University-A pulpit address-Sir Walter Davidson-Tantalizing applause -Pianoforte scholarships for Palestine . . . .

\section{CHAPTER IX}

\section{AUCKLAND JEWRY}

Jewish mayors-The Nathan family-A successful appeal-A civic reception-Jewish miners-The first New Zealander to enter Palestine-The Plunket nursing system-A dramatic poet .

\section{CHAPTER $\mathrm{X}$}

AMONG THE MAORIS

The Terraces of-Rotomahana-A region of geysers and springsIntelligent guides-Symbolism of Maori art-The influence of education-A dancing display- "A penny for a haka!" A Polish immigrant

\section{CHAPTER XI}

\section{WINDY WELLINGTON}

Successful Russian Jews-More Nathan families-An old schoolfellow-A veteran journalist-A Town Hall meeting-The Chief Justice-The Prime Minister quotes Ezekiel 


\section{CHAPTER XII}

IN SOUTH ISLAND

The struggle of Judaism-Jews in the Fiji Islands-A Jewish Prime Minister-From Christchurch to Tiberias-The Dunedin community-Mr. Lucien Wolf's brother .

\section{CHAPTER XIII}

\section{EXCURSIONS AND ALARUMS}

A visit to Masterton-A perilous journey-The Castleberg family -A New Year celebration-The Dominion Parliament-A shipping dispute-British-Israelites . . . .

\section{CHAPTER XIV}

\section{SYDNEY REVISITED}

A war-time melodrama-An embarrassing situation-An unexpected climax - A Barmecide feast-At Tattersall's ClubVisit to the Speaker-"Civilization and the Jews"- "What about Bolsheviks ?" . . . . . . . .

\section{CHAPTER XV}

THE MINOR COMMUNITIES OF AUSTRALIA

A gathering in Geelong-A venerable admirer of Harry LauderReceptions at Ballarat-Mayoral welcome at NewcastleBrass band at Brisbane-The Russian Synagogue-British Israelites again-A would-be Messiah-A silent audienceA Sabbath symposium-A sentimental Cantor-The Tango Maru-Adieu, Australia. . . . . .

\section{CHAPTER XVI}

THE PHILIPPINES.

Within the Barrier Reef-The Jews of Townsville-A stay at Thursday Island-Crossing the Equator-Natives diving for coins-Luxuriant Zamboanga-An exile from Syria-The Jews in Manila-A candid colonel-Canvassing an audienceA synagogue promoter-An unconventional meeting-A tremendous name-An ominous sciene . . . .

\section{CHAPTER XVII}

\section{HONGKONG}

A successful Jewish Governor-A Western Rabbi-The Jewish Recreation Club-The romance of the Sassoons-Bagdad the home of the Far Eastern communities-A sacred scroll from Nanking - Sir Ellis Kadoorie-A travelling circus-Envoys from the Holy. Land 


\section{CHAPTER XVIII}

\section{SHANGHAI}

Enterprising American Jews-A story about Sir Joseph LyonsAlong the Whangpoo-A cosmopolitan community-An orthodox stronghold-A student of the Cabbala-Oriental loaves-Levantine cookery-A fugitive from Kashgar-The survivals of the Kai-Feng-Fu colony-A Sabbath serviceA rickshaw problem-Economic depression-A palatial residence-Welcoming the Rabbi-A varied throng - The synagogue of Nagasaki-No Chinaman of the Jewish faithGenerous donations-Chin-chin joss ?-A handsome shrineAn expiatory well-An ambitious club-A Yiddish theatre :

\section{CHAPTER XIX}

\section{JAPAN}

A striking salutation-The Inland Sea-Fugitives from Russia -A social club-The Jews in Kobe-Judeo-Japanese marriages-A visit from a police official- "Where is this Palestine ?" -The Yokohama community-The Immigrants' Hostel-An interview with the police-Zionism and Bolshevism-A discouraging meeting-In quest of funds-A miserly banker-An interesting missionary-Links with Jerusalem and with Disraeli-A news agency report-Annoying visitors-The British Embassy at Tokyo-The charm of Kyoto-The Hon. Mrs. Gordon-The lost Ten Tribes-The Prince of Wales-A meeting in Kobe-The detective at Shimonoseki .

\section{CHAPTER XX}

\section{MUKDEN}

Travelling through Korea-The walls of Mukden-A Jewish home -Traders in furs-A Christian Zionist-A Bundist-Ghosts of the past

\section{CHAPTER XXI}

\section{THE CITY OF HARBIN}

Changchun Station-A phenomenal city-Intense cold-A varied population-Ex-prisoners of war-A centre of insecurityVictims of poverty-High prices-" Timber Town "-The pursuit of pleasure-Adventurers and mountebanks . .

\section{CHAPTER XXII}

\section{HARBIN JEWRY}

Origin and condition of the Jewish population-A medium of communication throughout Siberia-Vigorous communal vitality-Saturday night discussions-Sabbath service-Reb 
Yossel-Would-be settlers in Palestine-Jewish ex-prisoners

of war-The "Gymnasium "-A Palestinian conferenceChinese censorship-Mongolian delegates-An indefatigable enthusiast-A select gathering-A generous response-A strange ruse-At the Commercial Club-A midnight symposium .

\section{CHAPTER XXIII}

\section{TIENTSIN}

The journey from Mukden-An early welcome-The ConsulGeneral-The foreign settlements-In quest of Jewish nationality-A wedding procession-Serenading an AmericanThe Gordon Hall-A thé dansant-A heated discussion

\section{CHAPTER XXIV}

\section{PEKING}

My travelling companion-A sumptuous hotel-The British Legation-Interview with Sir Beilby Alston-An enterprising Russian Jew-The Inner and Outer Cities-The Temple of Heaven

\section{CHAPTER XXV}

THE STRAITS SETTLEMENTS

An American geologist's adventure-A Jewish commercial traveller-Christian missionaries-A quaint hotel-Jews in Singapore-Two synagogues-Mr. Menasseh Meyer-A patriarchal domain-Some unfounded complaints-Stipendiary worshippers-A Sabbath breakfast-A drawing-room meeting-A munificent donation-Canvassing support-Links with Bagdad-Wandering Jews-Lack of spiritual leader-Raffling sacred books-Want of charity organization-The Myrtle Club-Visit to Penang-A commentator's prophecy . .

\section{CHAPTER XXVI}

\section{JAVA}

On board the Melchior Treub-A deputation at Batavia-A sceptic in pyjamas-At the Theosophical Hall-The Dutch Jews -Religious indolence-Bagdadi Jews-Sephardim at Bandoeng-The Chinese New Year-Public dinner at Sourabaya -Marriages with natives-A sad apostate-Collecting at Semarang-A misunderstood speech-A Russian refugeeAn art exhibition-An operatic company-Back to Batavia -Jewish fellow-travellers-A quasi-patriarchal story-Wan-

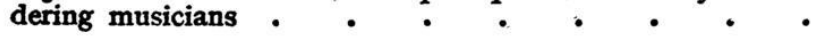




\section{CHAPTER XXVII}

\section{RANGOON}

A trilingual community-An endowed synagogue-The Schwedagon Pagoda-An unpromising prelude-A significant number-An entertaining raconteur-A coterie of bookmakers-A story about Crete-A treacherous tide-A lucky

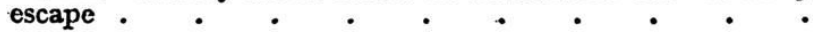

\section{CHAPTER XXVIII}

\section{Calcutra}

Along the Hoogli-History of the community-A Rajah's favourite-Three synagogues-Local pride-Various offeringsA curious rite-A private " 200 " - An old acquaintance-A man with Messianic pretensions-Quaint proposals-At synagogue on Sabbath-Oriental obeisance-A remarkable Ark-Memorial tablets-A second address-A strange adventure-Visits to schools . . . . . . .

\section{CHAPTER XXIX}

\section{BOMBAY}

The journey to Agra - " Shields of David "-The Taj Mahal-The sights of Delhi-A demonstrative welcome-A popular meeting-Professor Patrick Geddes-At the Cowasji Jehangir Hall-The Sassoons-A distinguished baronet-A unique tram-ticket-The origin of the Bene Israel-" Saturday oilpressers "-A brilliant military record-A social gatheringA public meeting - The Jacob Sassoon Free School-Refugees from Anatolia-A Judeo-Persian song-Legal bigamy-The Bene Israel school-Persian carpet-dealers-The underground community of Meshed-The Maharaja of PatialaThe new Viceroy-A lecture in the Red Sea

\section{CHAPTER XXX}

\section{PALESTINE REVISITED}

"Occupied enemy territory"-The evolution of the National Home-A Hebrew efflorescence-Haluzim at work-The Dilb settlement-Various projects-Building of houses-Technical Institute and University - School activity-An intellectual entertainment- $A$ colloquy in a cafe-The impotence of Eastern Jewry-The Arab problem-Praying for Zion .

Postscript .

INDEX

280 


\section{ILLUSTRATIONS}

Entrance to MaORI MOdel CAMp, Near Rotorua frontispiece HalUzim ON THE HRLOUAN IMMIGRANTS' CAMP AT JAFFA . $\quad . \quad \cdot \quad \cdot \quad \cdot 8$ JAFFA ROAD, JERUSALEM $\quad$ • $\quad$ •

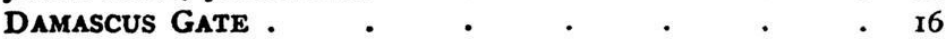
Avenue of Palms, Rishon-le-Zion . $\quad$. $\quad$. $\quad 24$ PIONeERS' Camp, Near PoOls of Solomon . . . 24 THE HON. JUSTICE ISAACS Lieut.-General Sir John Monash . . . . 50 The Hon. Daniel levy, Spraker New South Wales . 64 Mr. George Judah Cohen, Sydney . $\quad$ • $\quad$. $\quad$. 64 SYNAGOGUE AT AUCKLAND $. \quad . \quad \cdot \quad \cdot \quad \cdot 70$ MAORI WOMEN WASHING IN HOT SPRINGS . . . 70

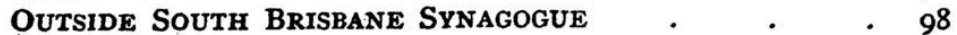
Members of Ballarat Jewish Community $\quad \cdot \quad \cdot 98$

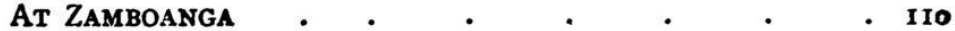
Colonkl JOSEPH N. WOLFSON, MANILA . . . 110 SYNAGOGUR AT HONGKONG $\quad$. $\quad$. $\quad$. $\quad . \quad$. 132 "TASHLICH" Well, ShanghaI $\quad . \quad$. $\quad . \quad$. 132 RABBIS OF HARBIN AND CHITA $\quad . \quad$. $\quad . \quad$. 168 HOTEL MODIRNE, HARBIN $\quad . \quad$. $\quad$. $\quad . \quad$. 168 Summer Palace, Pexing $\quad . \quad$. $\quad$. $\quad$. $\quad$. 186 Gordon Memorial Hall, Tientsin . . . . . 186 Mr. Menasseh Meyer, Singapore . . . . . 200 Mr. MeYer's Synagogue $\quad . \quad$. $\quad . \quad$. $\quad$. 200

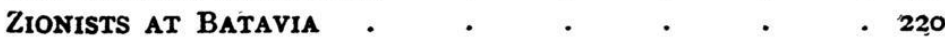
Malay huts at Penang.$\quad$..$\quad \cdot \quad \cdot 220$ WELCOME WITH GARLANDS AT BOMBAY . . . 250 FAcsimile Message of Meshed JeWS . . on p. 265

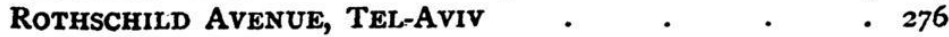
AT THE WESTERN WALL, JeRUSALEM. . . . 276 MAP ILlUSTRATING AUTHOR'S ITINERARY . . End Paper

(The illustrations are, with few exceptions, from photographs taken by the Author.)

$\mathbf{x v}$ 


\section{THE JOURNAL OF A JEWISH TRAVELLER}




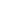




\section{THE JOURNAL OF \\ A JEWISH TRAVELLER}

CHAPTER I

THE PIONEERS' PILGRIMAGE

MONG my fellow-passengers on board the
Helouan, on which I sailed from Trieste to
Alexandria, the poorest seemed to be a band
of young Jews who travelled steerage. Their hand, and it became slighter still in the course of the voyage, for it consisted largely of cheap provisions which they had bought for the journey. They ranged in age from twenty to thirty ; they were sturdy and muscular, most of them with tanned faces, and all with straight backs. But one of the group, although tall enough for twenty, was only sixteen, a retiring, bashful lad in a Cossack-like garb-high boots, shirt buttoned close round the throat, and wide breeches with a thin red stripe down the side. And another member of the group was a girl-short, robust, and with sunburnt face. They sought no comforts on board the vessel, nor did they study the relative merits of cabins with port-holes or without. They sat where they could during the day, and at night they stretched themselves out on deck, beneath the star-lit sky, where they slept as soundly as on a bed of down. But one of them in turn was always awake for an hour, to watch over his comrades and over their 


\section{THE JOURNAL OF A JEWISH TRAVELLER}

common possessions, though their appearance certainly offered little temptation to any potential pilferer. The rota of watchmen, with their names all in Hebrew, and the hours of duty fixed, was posted on one of the funnels.

Outwardly the poorest of all the passengers, they were inwardly the richest and happiest, for they had left behind them the lands in which they had suffered and were sailing to the land of their dreams. They came mostly from Poland and Galicia, where, ever since the end of the war, they had found no peace and had thus resolved to shake off the dust of their unnatural mothercountry. From the glorious red-letter day when they had first heard of England's historic promise concerning their ancestral land they had patiently awaited the signal for their return, and meanwhile they had prepared themselves for the new life before them by working in small groups on different farms.

"But we could wait no longer," said a sturdy youth to me, as we stood in the rear of the vessel, gazing across the blue, rippling waters of the Mediterranean. "We got tired of waiting and decided to get to Palestine as best and as soon as we could-as Haluzim. ${ }^{1}$ Our journey was anything but easy, but we were determined. We were warned of the difficulties and privations we should undergo if we came unexpected, but nothing could be so bad as the conditions we have left behind. Several of us have come from Lemberg, where the daily persecution of Jews still goes on, though not so violently as in the days of the pogroms. We are students, but the University is closed to us. So we went to work on a Jewish farm some miles away, and our hands that were formerly used only to a pen or a test-tube can now handle a spade and a scythe with the utmost ease. Our labour was good enough to be rewarded, and so, with frugal living, we were able to save something for the cost of our journey. Our employer was sorry when we left, for he found us better workers than the ignorant

\section{Pioneers.}


Ruthenian peasants whom he engaged, and he asked us to send him successors as good."

"But how were you able to get to Trieste ?" I asked.

" Ah, that is a long story," responded another member of the group who gathered round. "I belonged to the self-defence militia in Lemberg during the pogrom, so the Poles were not willing to facilitate my journey. Well, we went without visas, and some even without passports, and as we had to avoid frontier gendarmes and other disagreeable obstacles, we did a good part of our journey on foot. Never shall I forget our climb across the Carpathians: that was a tramp! We were tempted at many a spot on the road to begin singing the Hatikvah to cheer us up, but were afraid we should attract the attention of the guards. One or two of us got passports at Teschen. You have heard of, Teschen. It is a most convenient place just now, as there is a plebiscite going on to decide whether it shall belong to the Poles or to the Czechs, and so, of course, it is the easiest thing in the world there for anybody to get a Polish or Czechish passport, as both nationalities welcome you."

" But some of us were not so lucky as that," observed a broad-shouldered young fellow, whose spectacles and ascetic face told of the studious days he had lived. " Four of us who had no passports were arrested on the frontier by the Czechs, who kept us in prison for a couple of weeks. They called us jestingly Palestinichki, because we said we wished to go to Palestine. They made us do the most menial and filthy work. Still, we got away, and it was an adventure. After that we came to a place in Bohemia, not far from Pressburg, and whilst three of us worked-and worked hard too-on a farm, the fourth used to go to Pressburg, to get our papers in order and attend to our affairs in general. You see, we worked already like a little co-operative society."

"Still, that does not explain how you got to Trieste," I remarked. 


\section{THE JOURNAL OF A JEWISH TRAVELLER}

"Through Vienna, of course," replied the ex-member of the Lemberg self-defence corps. "We got a Jewish visa."

"A Jewish visa ?" I repeated in astonishment.

" Just look at this," he replied, and, opening out his well-thumbed passport, he showed me the Hebrew endorsement of the Zionist Palestine Office in Vienna, written across one of the familiar Herzl stamps of the Jewish National Fund. "But of course this Zionist visa would not be enough without the British visa, though without it we should not have got the British visa."

"Yes, we are beginning to live in Messiah's times," remarked a fair-haired youth. "I was born and brought up in Holland, far from Jewish influence and surroundings. But during the last four months I have worked on the land with many other young Jews, training for the cultivation of our own land. There are about forty pioneers altogether, including a few girls, who are now training in Holland, in two or three different centres." And then he added, with a look of pride: "I speak Hebrew too, though a few months ago I could not even say a Beracha."1

"Ah," continued the pioneer from Lemberg, "if you only knew the wave of enthusiasm that is now passing over the Jews, especially the young Jews, in Eastern Europe. If you only knew of the envy with which the younger ones at home saw us leave, and how they promised soon to be ready to follow us. For us Palestine is the only redemption. In many cases parents who can't go themselves are trying to prevent their children from going, as they don't wish to lose them. More than one young friend of mine has been tied to the bed at night by his father so that he might not escape. But all these attempts to stop us only increase our determination. I know a young girl, still under twenty, of a rich family in Lemberg, who made up her mind to go to Palestine, so her parents took her photograph to the authorities and begged them not to give her a pass-

1 Blessing. 
port. She therefore got somebody else's passport, pawned some of her jewellery, and reached Vienna. There, as she was without money, she went to an aunt for assistance, but the aunt had already received a telegram from the parents begging her not to help the girl in her intention, but to send her home. But the girl would not listen to the idea of returning home, so at last her parents relented and the happy girl was enabled to complete her journey to Palestine."

" Perhaps I shall meet her there," remarked a comely but rather pensive and bashful girl, who had hitherto remained silent.

"Are you also going to work on the land ?" I asked, looking at her frail figure.

"No, I am going to prepare a home for my parents. I come from Pinsk, where life has now become a torture under the Poles. Several of the thirty-five Jews who were massacred there last year by the Polish soldiery were personal friends of mine. Yes, I have bitter memories of my native town. And, oh, the journey from Pinsk to Warsaw! Never shall I forget it. The poor Jews were abused, assaulted, and robbed all the way-on the road or in the train, it was all the same. I had more annoyance and suffering on that short journey from Pinsk to Warsaw than on the whole of my long travel from Warsaw to Trieste. And the Poles are such a cultured people!"

"That is why I also came away," interjected a lean and haggard elderly Jew, clutching his grizzled beard with his right hand. "I went back to Cracow to see my children. But do you think I would wait until the Poles had plucked out my beard ? May they not live to such a day!"

"And what will you do in Erez Israel?"1 I asked, surveying his weak and stunted figure.

"What I did before. I lived there before the war too." "But how ?" I continued.

1 Land of Israel. 


\section{THE JOURNAL OF A JEWISH TRAVELLER}

"Learned and lived from the Halwkati":

3

"And drank too a little, Reb Leibush," jestingly interposed one of the young men.

"Nu, for Kiddush" and Havdoloh" a poor Jew must drink a little," retorted the greybeard.

The pioneers had touched upon one of the weakniesses

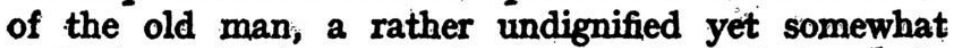
pathetic and picturesque representative of the early settlers in the Holy Land, whom they frequently bantered about his foible.

"But don't think," said one of the more serious members of the group, "that we are going simply as fugitives from persecution, for then we should go to other countries where all comforts and conveniences are ready. No, we are willing to work in the sweat of our brow, for we wish to help to rebuild our land, our longneglected land."

They were a joyous and courageous band, that group of pioneers, full of strength and hope, and with a look of triumph in their keen eyes. During the day they discussed the happenings of the past and the plans they had formed for the near future, and when night came down upon the sea, and the steerage was steeped in darkness, they gathered round and sang Hebrew songs with a lusty refrain. At first their songs were of the days of oppression and exile they were leaving behind, of the poverty and pathos of the Ghetto and all its old-world piety-songs of ineffable sadness, in a hauniting minor key. But soon they burst forth into a robust and lilting chorus, proclaiming the redemption of the Land of Israel and heralding the dawn of a new and glorious age. And as their strong young voices, in resonant concord, floated in bold crescendo across the sea I could hear in them not only the accent of the pioneers but the march of the conquerors.

1 Charity fund contributed by Jews outside Palestine.

2 Benediction on the eve of Sabbaths and festivals.

- Benediction on the termination of Sabbaths and festivals. 


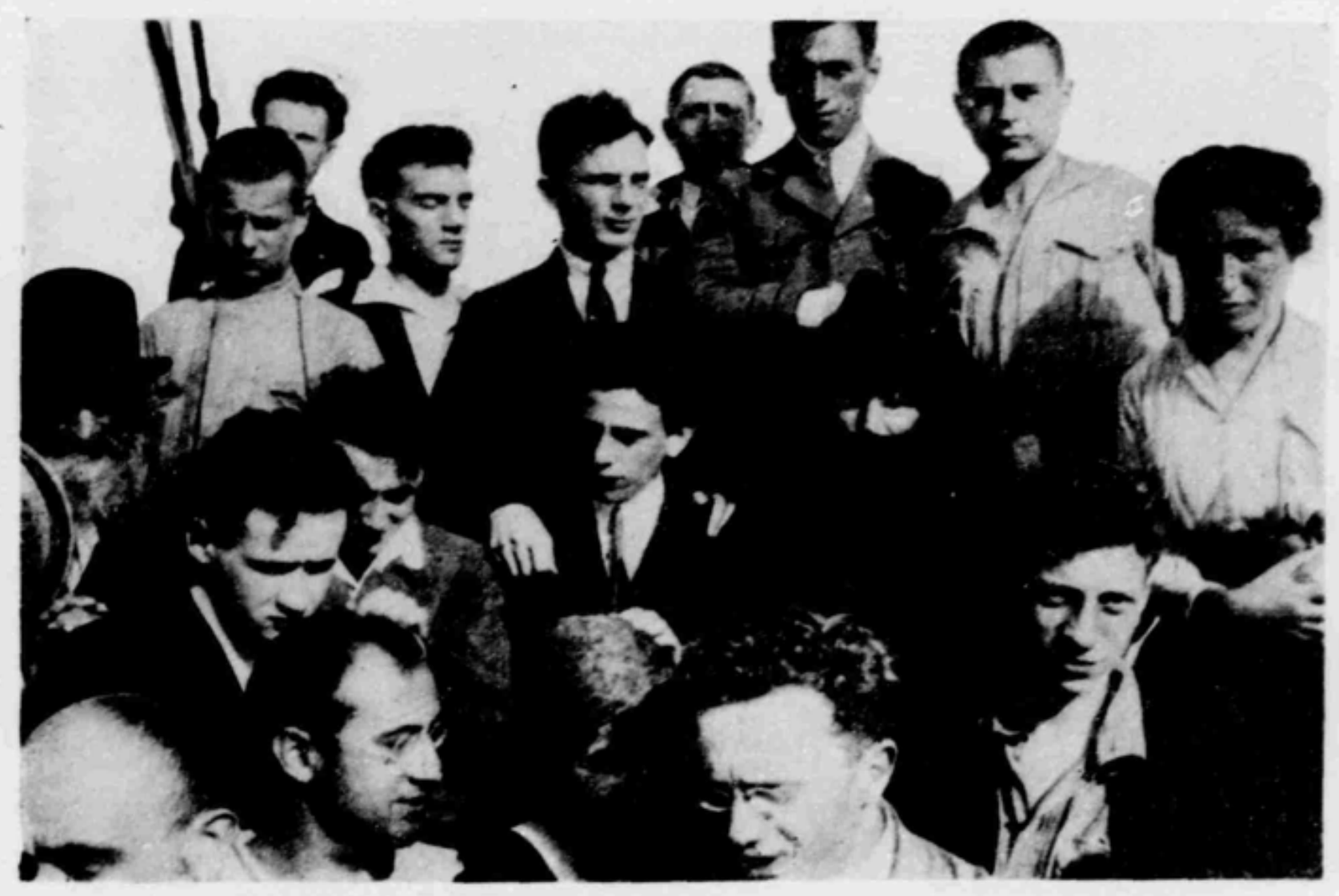

HALUZIM ON THE HELOUAN

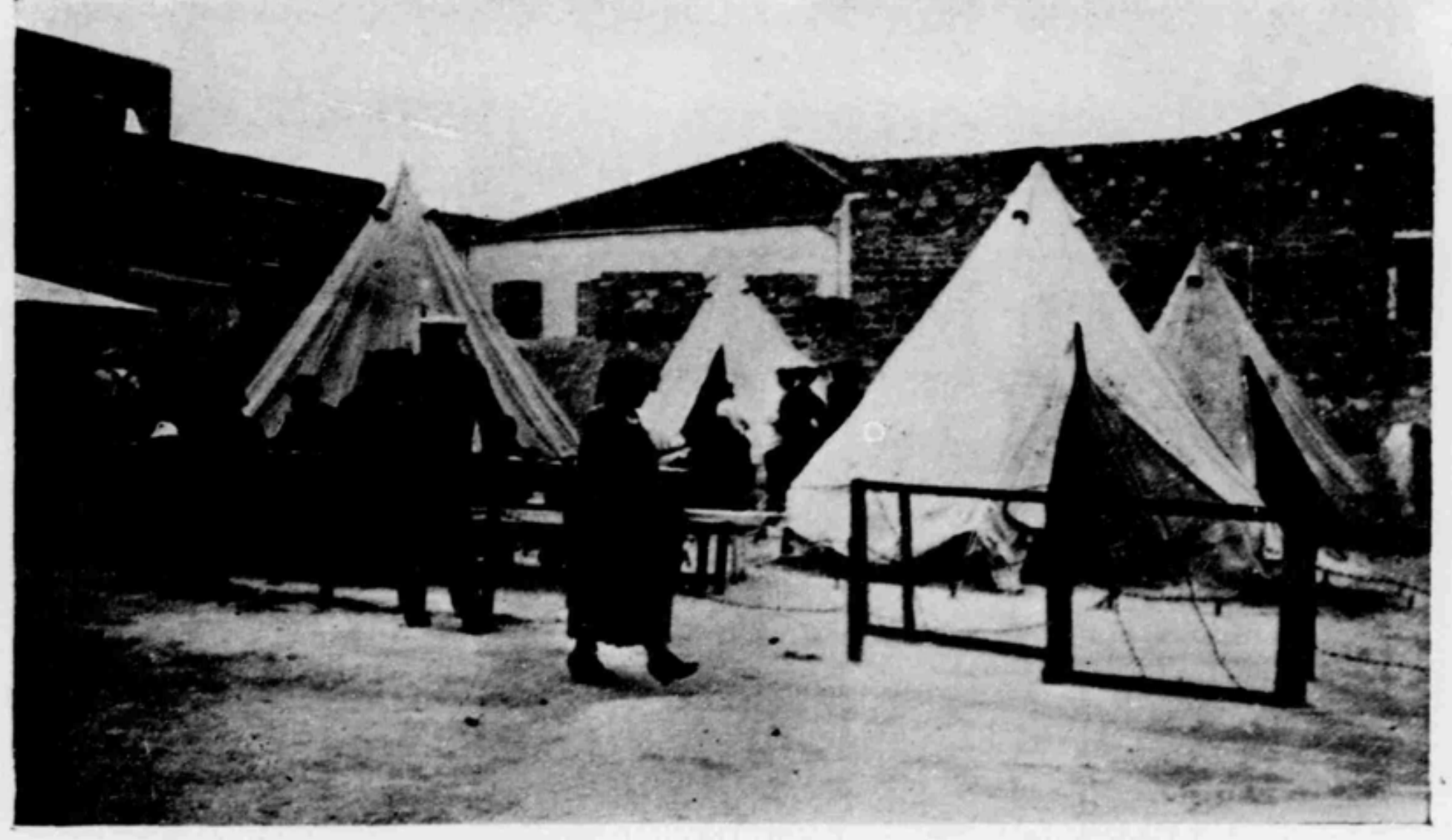

IMMIGRANTS' CAMP AT JAFFA 


\section{CHAPTER II}

\section{IMPRESSIONS OF JERUSALEM}

\section{I}

HE Children of Israel took forty years to travel from Egypt to Palestine. Their modern descendants can accomplish the journey in less than a day; yet, spoiled and pampered by contemporary comforts, they may murmur on the way perhaps more than the foot-weary hosts that were led forth by Moses. For though you can leave Cairo in the evening in an up-to-date train, in which you can dine satisfactorily, and even slumber undisturbed in the sleeping-car which halts overnight at the frontier station of Kantara, you are brought early next morning into the heart of the Sinai Desert, and as you gaze at the vast sandy waste through which the British Army has laid the track on which you are travelling you may slowly and imperceptibly feel a certain misgiving. For hour after hour you pass through an arid, treeless expanse, which is apparently limitless on the one side, whilst bounded on the other by the Mediterranean coast, not far from which the line runs for many miles. For hour after hour you see naught but fine, soft whitish sand, plains of sand, hillocks of sand, and undulating valleys of sand, as far as human vision can reach, until the eye begins to tire and the throat to feel parched.

The journey is interrupted for a few moments at Rafa, where there is a primitive station, and at Gaza, where Samson wrought damage among the Philistines in the hoary days of old, and British projectiles wrought still greater damage a couple of years ago. Everywhere is 
the same arid, barren, monotonous prospect, void of trees or flowers, of fields or meadows, with not even a pond or rivulet to slake in imagination the thirst of the weary traveller. So, despite the oppressive heat, there may gently steal over you a faint tremor as you hesitatingly put to yourself the question: "Is this, indeed, then the Promised Land ? Is this the land once flowing with milk and honey?" The question is inevitable, but it, should not be put so soon lest it be answered falsely. The physical convenience of reaching Jerusalem from Egypt by land is counterbalanced by the moral ordeal of sustaining one's faith through the wilderness. Those who approach it from the sea are spared this trial of faith, for, though tossed about in the boat that brings them to the Jaffa strand, they soon behold beneath the deep-blue sky the leafy. avenues and the picturesque rows of trim white stone houses of Tel-Aviv, created by Jewish hands on the very spot that, but ten years ago, was likewise a bare sandy waste.

But there is another trial soon in store. It is the change at Ludd and the completion of the journey to the Holy City in a train that combines simplicity with discomfort. Before the war Ludd was little more than a name. Now it is a tumultuous, all-important junction. But the offices, stores, refreshment rooms, all are low wooden barracks. The red sandy platform, exposed to the heavens, swarms with a motley, perspiring throng: military officers in sun helmets, nurses in white dresses and straw hats, Galician Jews in long gaberdines, Arab women and children squatting on the ground against the wall, venerable Sheikhs and black-veiled Egyptian women, Europeans and Americans of varied type and accent, all jostled by Arab porters, who seem to carry on their backs as much as an English porter can wheel on his truck. But you seek in vain for a stationmaster or anybody wearing a uniform suggestive of such a functionary. Then you realize that this is still a military railway, and a stalwart non-commissioned officer advises you how to get your 
luggage together and proceed on the final stage of your journey. ${ }^{1}$ The clerk in charge of the luggage-van speaks a medley of tongues, flitting lightly from English to French, from Arabic to Hebrew, with the practised ease of a polyglot professor; and then you find yourself and all your belongings deposited in the train that will bear you, after waiting half an hour, to the Holy City. Most of the carriages in it are small, with a plain wooden bench on one side, though you will probably be too deeply. intent upon the scenery to feel the hardness of the seat.

The train starts moving, before you are aware, without any apparent signal, and for the next three hours you are borne up a steady incline, with frequent gradual curves and occasional halts, along a road that runs partly through plains, with a view of increasing vegetation the higher you rise. At the wayside stations clamorous Arab boys offer huge melons at a shilling each, cutting them open first, if you wish, to prove their fitness ; and after you have refreshed yourself with the fruit you patiently await the arrival in the Holy City. Even in summer the sun begins to set here soon after six, and as you drive away from the bustling station you see the quiet city bathed in a flood of pale golden light, which quickly fades into dusk.

Jerusalem is a city of unique and multifarious charm, quite apart from all its wealth of sacred sites and historic associations. To measure it by the standards of any Western city were to attempt the unreasonable, for its beauty lies not in imposing buildings or spacious boulevards, in leafy avenues or magnificent parks, but in its radiant colouring, its picturesque grouping and its melancholy desolation. The white stone of its walls and houses gleams brightly in the sunlight, and from many a coign of vantage you enjoy a glorious vista of terraced hills, dappled with red-roofed houses and clumps of trees,

1. Written in 1920. 
I2 THE JOURNAL OF A JEWISH TRAVELLER

spreading before you in amphitheatre form, and unblemished even by a puff of smoke.

The ancient city, starting from the Jaffa Gate, is bound to lure you, despite its smells and its slippery cobble paths; but as you walk through its native bazaars, descending a step at almost every yard, and threading your way through the chaffering crowd, you feel that these are but slums of a more romantic and picturesque order, and that not here-not in these congested, insanitary hovels, from which the light of day is often hermetically shut off-can the New Jewry arise. The ancient city should remain, cleansed and purified; but no matter how deeply steeped in sacred memories, no matter how heavily charged with pious aspirations, it cannot, as it exists to-day, form the home of a healthy generation that seeks to produce still healthier generations in the days to come. But beyond the confines of the ancient city, beyond the lofty massive walls that still engirdle it, new quarters can, and must be built, fit for the pioneers of the Jewish Commonwealth.

The most splendid view in the ancient city is that which embraces the Mosque of Omar-surely the most magnificent shrine in the whole land-and the neighbouring smaller Mosque of Aksa, which rear themselves aloft upon a flat and spacious site like a plateau, the old Temple area, visible to all the winds. But should you seek a Jewish shrine, should you ask where are the prayers and hymns of Israel offered, you are led first to one and then to another synagogue, neither of which can claim an antiquity of even a hundred years, and both of which are so completely hidden away in narrow alleys that they must be sought with cunning and determination. In no other city that I know has the lax Jew so legitimate an excuse for not attending public worship. All the great cities of the West have an imposing Jewish sanctuary: Cairo, Alexandria and Rome, to name three of the nearest communities, each have a grand and monumental synagogue that can claim equality with 
the buildings around it; but the home of prophets and psalmists, the centre from which the Law and the Word of God are to go forth, does not possess a single Jewish fane with the least pretensions to magnitude of structure or nobility of design. And yet Jerusalem has re-echoed for so many decades with the passionate supplications of hosts of pietists, of those who came here for no other purpose but to pray-and die. But for their prayers they wished no ornate pile of marble and gold, with far-stretching aisles and stained glass windows, and the uplifting strains of a rich-throated choir; they wished for naught but the grim, solid remnant of the ancient Temple, before which they could daily beat their breasts in abject contrition.

There, one Friday afternoon, before the setting of the sun, I saw a group wrapt in prayer, standing close to the Western Wall. I had always conceived this ruin as situated in a large open space reminiscent of the courts of the Temple, and I was surprised and disappointed to find that it formed just one side of a narrow blind alley. The approach is also through narrow alleys, crooked and cobbled, with old men and women, bleareyed and ragged, squatting like Arabs on the ground against the walls, and holding out their withered hands, with the ceaseless whine: "Gibt Zedokah! Schenkt a Nedovah!"1 The approach is rendered disagreeable further by its being surrounded entirely by poor Arab houses whose inmates at times indulge in abuse of the devout worshippers, seeking to interrupt their prayers. Only the five lowest tiers of the Wall, containing the largest blocks of stone, are believed to be genuine survivals of the second Temple; but even they reach far above the heads of the tallest worshipper, and the most critical research into the composition of the ruin will leave unaffected the piety that gathers before it. And even though the Galuth ${ }^{2}$ is at an end for all who wish to end it, and the Land of Israel is open to its scattered
1 "Give charity! Give alms!".
2 Exile. 


\section{I4 THE JOURNAL OF A JEWISH TRAVELLER}

people, the Wall is still frequented daily, is still made the recipient of fervid petitions, albeit they seem to have diminished in passion with the increasing prospect of the national resettlement. But though no more plaints or confessions should ever be uttered before it, it will always remain a singular and sacred link with the venerated past, a symbol of national endurance and impregnable faith; and it should therefore be preserved in a worthy manner. The Arabs who dwell within its shadow should be provided with more comfortable and attractive dwellings beyond the ancient walls, and then their dark ugly hovels that disfigure the vicinity should be ruthlessly rased to the ground.

Nor are these the only things that call for destruction, for in various parts of the old city there are heaps of rubbish and rubble, daily growing into hillocks, which should be swept away completely, leaving suitable sites for a useful building or health-giving garden. What a splendid field for the inspired architect, for the townplanner with the gift of imagination, who will transform the city of Zion, with its dismal hovels, its reeking alleys and its patches of desolation, into a place that shall truly answer its description of aforetime: " beautiful in situation, the joy of the whole earth!" Beautiful, indeed, is the city from afar, above all from the Mount of Olives, whence your eyes can sweep over the whole peaceful, picturesque country as far as the Dead Sea ; it can and should be made beautiful also when seen close at hand. And its streets should all be given and bear names, so that the unwitting stranger in quest of a friend's hoùse should not be led astray by police hiding their local ignorance under the veneer of oracular authority. 1

\section{3}

Half of the Jews in Palestine live in Jerusalem, yet is there less of a Jewish impress on the life and complexion of the capital than in other towns with fewer Jews, and

1 The naming of the streets has since been carried out to some extent. 
still less than in any colony. True, most of the shops in the principal thoroughfares bear Hebrew names, and the little red letter-boxes are painted with a Hebrew as well as an English and Arabic designation, and there are two Hebrew dailies and still more weeklies and monthlies, and thousands of Jews-many of them in Oriental flowing robes-live in separate quarters, whilst most of them, especially the younger generation, speak only Hebrew. But all the big dominating buildings belong to the Gentiles. The vast, fortress-like hospice of the Russians, the lofty ornate hospital of the Italians, the large convents, schools and what-not of the French, all ostensibly devoted to some fine cause of humanity, though erected originally with an ill-concealed political motive-they all dwarf into insignificance the few structures of any pretensions that are in Jewish ownership. The Rothschild Hospital, efficiently equipped though it is, or the Bezalel School, with its precious creative work, cannot compare with the monumental edifices that have been raised in the interests of other nations.

Either we have been content too long only to pray for Zion, imagining perchance that some day a Messianic wand would conjure mansions and temples, parks and palaces, out of the dust, or else we lacked the political influence, the generous State resources, with which other nations have firmly established themselves here. But the omissions of the past can now all be made good. Those who so fervently and repeatedly pray for the rebuilding of " Jerusalem, the Holy City, speedily in our days" can now demonstrate the sincerity of their entreaties by handsomely contributing to the cost of rebuilding. But, oh, let the buildings be of more pleasing style than those dull, gloomy, barrack-like dwellings, in which are pent the pious dependents, with their numerous progeny-may they ever increase!-of the various Halukah conventicles!

There is a splendid collection, systematically arranged and classified, of all the fruits, flowers and trees of the 


\section{I6 THE JOURNAI OF A JEWISH TRAVELLER}

country, of its fossils and mineral deposits; of its birds, insects and snakes. Apart from its scientific value the collection has a practical importance, for it shows how large and luscious the fruits of Palestine can grow and how well they can be preserved-a science undreamt of by the Arabs. The collection has been organized by the Agricultural Department of the Zionist Executive and is inadequately housed in a few ill-lighted rooms, already overcrowded with their instructive exhibits. When will some minor Rockefeller of the Jewish people establish and endow a Natural History Museum that shall be worthy of the land of Israel ? A beginning is being made with the installation of a Jewish National Library in premises quite unequal to the importance of such an institution. When will some minor Carnegie arise in our midst and enrich the Holy City with a fitting treasurehouse for the literature of Israel and of all nations ? When will the vaunted People of the Book vindicate its traditional title by raising a dignified mansion for its traditional lore in the land of the Book ?

And, above all, when will the Hebrew University begin to emerge from the realm of ideas into that of reality? By a wonderful stroke of inspiration this was the first Jewish institution whose foundations were laid after the issue of the epoch-making Declaration by Mr. Balfour. The ceremony proclaimed that it was not by might but by the spirit that the Jewish Commonwealth would be built up, and from all over the world arose prans to the wisdom and justice of the grand conception. But two years have passed, no further constructive step has been taken, and the foundation stones are beginning to look quite lonely. The question has, indeed, been often considered, and an elaborate plan has been devised for a noble and palatial academy which shall arise on Mount Scopus, with a magnificent outlook upon the city and upon the whole of the surrounding country. The plan has been worked out with some detail in regard to the disposition and design of the halls of the various 



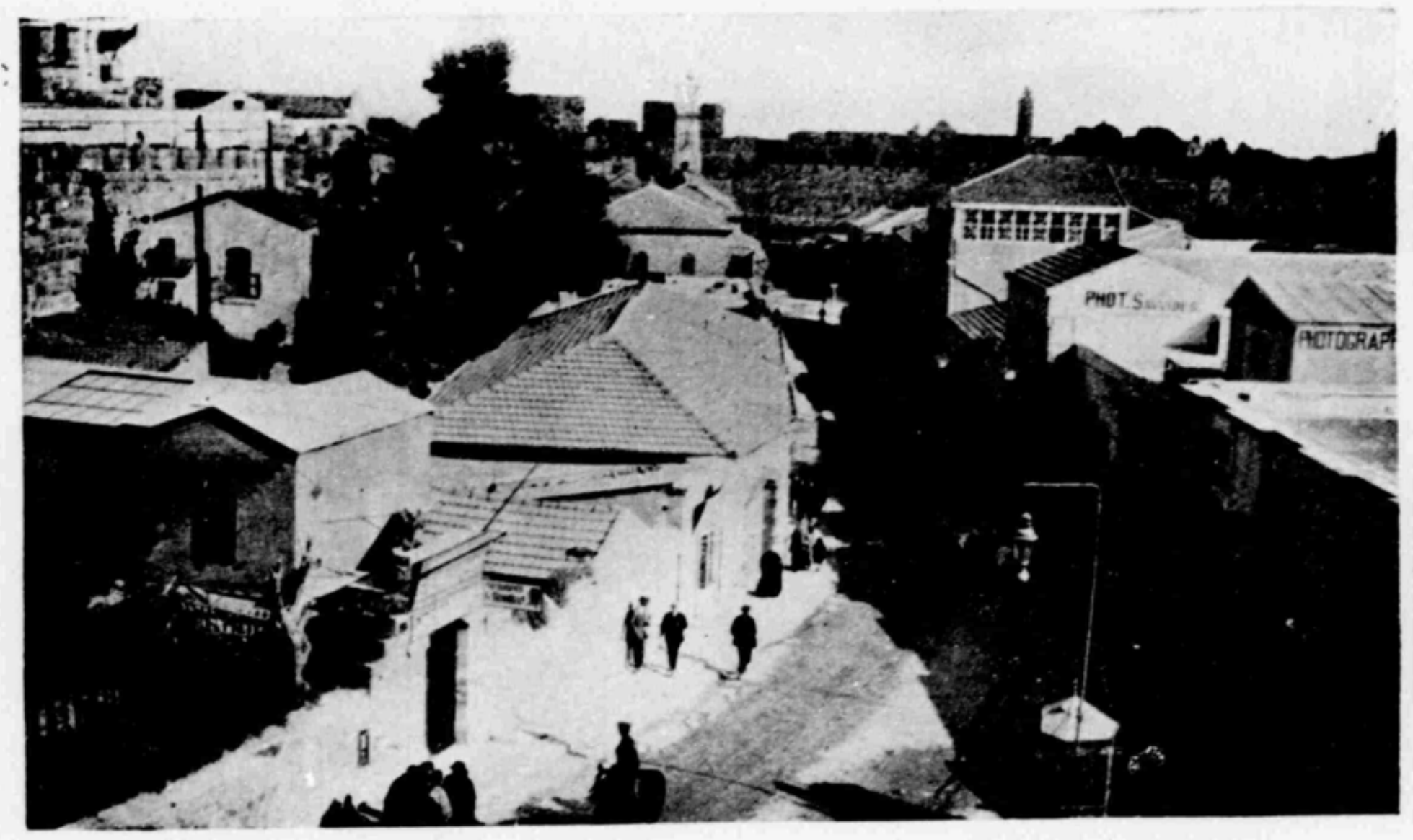

JAFFA ROAD, JERUSALEM

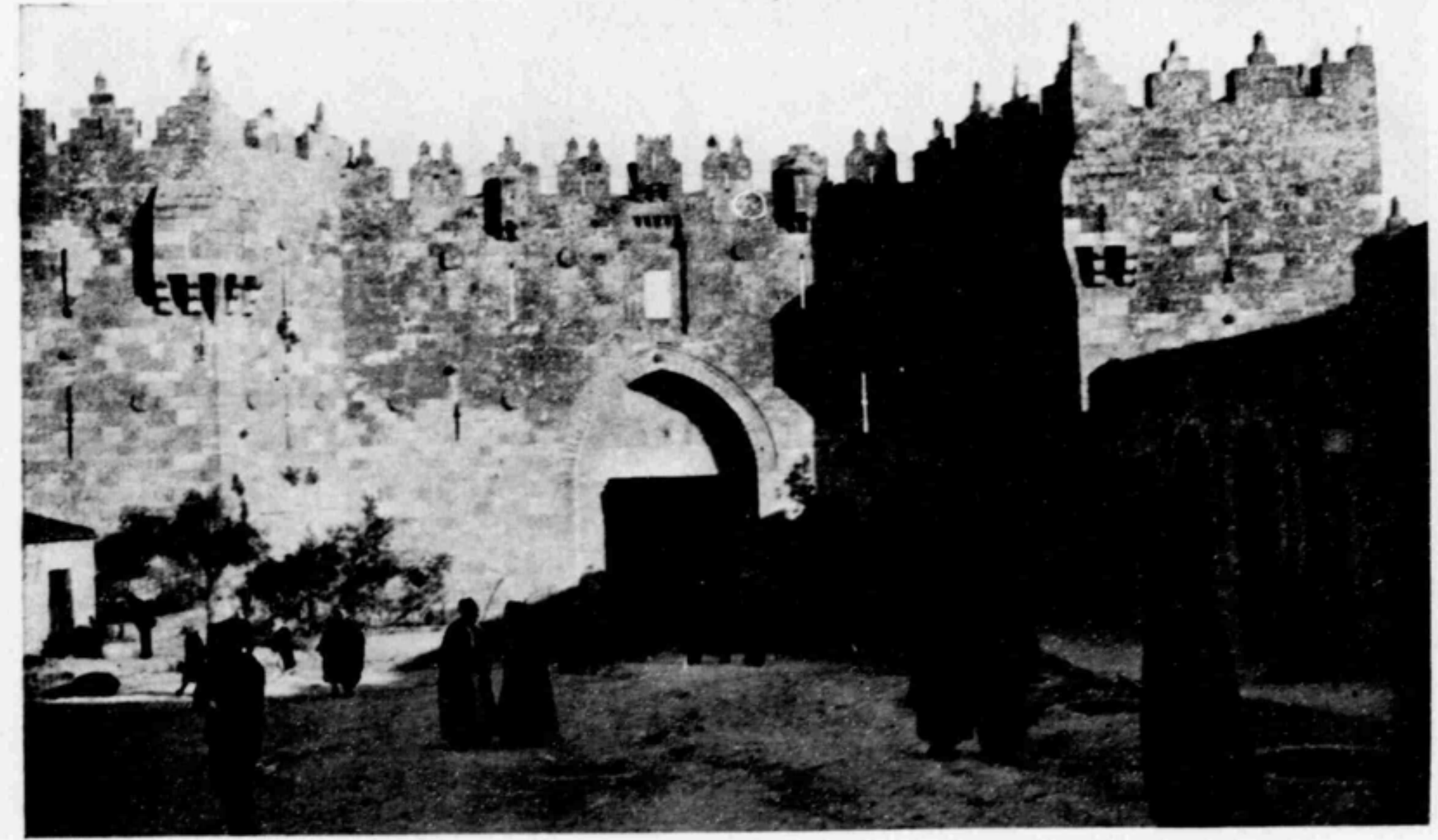

DAMASCUS GATE 
Faculties, and provides for the making of a new road that shall run from the city to the University. But the estimated cost of executing the plan is high, and so, for the present, it is perforce hung up. But there is an alternative scheme for the conversion of the house of Sir John Gray Hill, which is included in the bigger plan, into a provisional academy of scientific research and Hebrew learning, the nucleus of the great University of our dreams. It would, indeed, be a misfortune if this more modest proposal were also held up for lack of money. This is surely an object upon which all should unite, be they swayed by political convictions, or moved by religious sentiments, or prompted solely by humanistic aspirations. A University for Jerusalem was acclaimed years ago, even by those who set their faces against the national resettlement of Palestine, as a crowning work for the hands of modern Jewry. ${ }^{1}$ Will modern Jewry be as resolute and generous in action as it is fertile in ideas, or is it willing to be written down as unworthy of the glorious opportunities before it ? All those who so solemnly declare, "If I forget thee, $O$ Jerusalem, may my right hand forget its cunning," when will they give freely of the fruits of their cunning so that Jerusalem shall be not only remembered but redeemed ? And all those who perfervidly protest, "Next year in Jerusalem!" when will they make a sacrifice for its restoration, so that when they do see it "next year" they shall find it in very truth " beautiful in situation, the joy of the whole earth."

1 See Postscript at the end. 


\section{CHAPTER III}

\section{THE JUDEAN COLONIES}

HE Jewish colonies have been described as the oases of Palestine, a description that seems to imply that the rest of the country is desert. Much, only too much, of the country is indeed bare, through centuries of neglect and devastation; but there are also large areas under Arab cultivation, yielding corn, fruit and vegetables. The Arab plantations, however, as I saw them on the road from Jaffa to Ludd, and again from Haifa to Tiberias, present a rather sorry and forlorn appearance, still reminiscent, as regards the methods of their cultivation, of Biblical times. The Arab planter sows his plot of land with his own hands, and then rears upon it a skimpy booth of branches, as pictured in one of the visions of Isaiah, wherein he daily sits and watches, sheltered from the sun, until his crop is ready for ingathering. These small, isolated plantations make for stagnation and monotony, and produce only a minimum yield. Not so the Jewish colonies, which represent the collective effort of an energetic group, bent not only upon providing sustenance for themselves individually, with the aid of up-to-date methods, but also upon developing all the phases of communal life. For the Jew is a gregarious animal, and in the Palestinian colonies this quality has manifested itself in its finest and most fructifying form. But for these rural settlements, which now have a history of more than forty years, one might perhaps still doubt whether we could again make the land flourish, in spite of the prosperous Jewish farmsteads of Argentina and 
the United States. But these Jewish rural communes, created without experience and developed amid difficulties, afford the surest guarantee that Jewish hands can again make the Land of Israel flow with milk and honey.

\section{I}

The first colony that I visited was the first that was established, namely, Petach Tikvah. Its early history is a record of endurance, privation and disaster, for its founders were stricken down by the fever of the neighbouring marshes and were compelled at first to abandon their endeavours. But soon afterwards they returned to the task and triumphed, and Petach Tikvah became one of the largest and most flourishing colonies. It covers an area of nearly 8000 acres, and a few years ago it had a population of 4500 ; but it suffered seriously during the war, and its inhabitants, through various causes, have diminished by a third. For one month it was the head-quarters of the Turkish Army, and for eight months the head-quarters of the British Army, whilst for an even longer period it was exposed to the shells from both sides.

There is no train to Petach Tikvah from anywhere. ${ }^{1}$ There is only a diligence from Jaffa, which runs at fixed hours and at a leisurely pace, and as my time was severely limited I did the journey in a motor-car. I was told that the approach to the colony was rather sandy, but I did not appreciate what this meant until we reached the outskirts. Bad as the road was in many places, it suddenly disappeared altogether in a flood of soft, yielding sand. The car could go no further, and the chauffeur advised us (I was accompanied by an official of the Tel-Aviv community) to proceed on foot and send a couple of Arabs to his assistance. We ploughed our way along in the sand for at least a quarter of an hour before we reached the house of the elderly colonist to whose built.

1 A railway connecting Petach Tikvah with Jaffa has since been 
guidance I was recommended, and after he had sent the required aid to the stranded chauffeur he related to us the experiences of the colony during the war.

"Why is there no proper road to this colony?" I asked.

"For the same reason that there is no proper road to the other colonies," was the answer. "Because the Turks had no desire to improve the conditions of the country. We wished to make a road ourselves, although it would have cost us $£ 20,000$; but we had first to obtain the permission of the Turkish authorities, and as that would have cost us another $£ 40,000$ we had to abandon the idea. The question of transport is very serious. Our yield of oranges before war amounted to 400,000 cases, besides 300 tons of almonds and an equal quantity of grapes. All this has to be conveyed to Jaffa by camels for export-a very slow and unsatisfactory method. It, therefore, occurred to us that it would be much better to carry our products by boat on the River Audja, but when this proposal was made to the Turkish authorities there was a cry of indignant astonishment: 'What! The Jews want to have a fleet!' So nothing could be done. But now I am happy to hear that Baron Edmond de Rothschild has generously undertaken to build the road, and the Government has promised to build a railway."

Our guide conducted us through a part of the plantations and showed us the far-reaching groves of oranges and almonds, of grapes and olives, as well as the woods of eucalyptus that have been planted to stamp out the malaria and to provide much-needed timber. The entire plantations cover an area of 26,000 dunam, ${ }^{1}$ apart from 4000 dunam occupied by houses and gardens. The colonists had finished their day's work and were seated in their doorways or standing about in groups in the streets. We visited the communal pharmacy (a wellstocked and well-arranged store), the school, the syna-

1 A dunam is equal to a fourth of an acre. 
gogue, and the public hall, all institutions administered by the elected council, which enjoys the fullest autonomy.

There are two governing bodies, a central executive and a supreme council, the former being subject to the latter, though they are elected on a different basis. The executive, consisting of seven persons, are chosen by the 1300 electors of both sexes above the age of twentyone, and then the executive conduct the election of the supreme council of forty-five, who are appointed by the nine different parties or groups of the colony, such as the landowners, the labourers, the almond-growers and so forth. It seems a rather complicated system, but I was assured that it works well. The executive meet every week, whilst the chairman, vice-chairman and treasurer are in permanent session. These three officials, owing to their multifarious and arduous duties, are henceforth to be paid. We found them, on our visit to the public hall, busily employed in counting up the donations given by the colonists in the Week of Redemption: they informed us joyfully that $£ 9000$ had been subscribed. Public security, which means protection against Arab raiders or robbers, is maintained by a body of ten armed watchmen, whose number during the orange harvest is increased to thirty. There is a school containing a thousand pupils, boys and girls, besides an agricultural school with twenty-six pupils. The total value of the colony's products before the war was $f 80,000$ a year: now there is every prospect of a considerable increase.

Our chauffeur decided to avoid the sandy track on our return journey and so struck out along a good hard road, - which we fondly hoped would continue all the way to Jaffa. But we had scarcely driven more than ten minutes than we found ourselves, with the darkness thickening, in a narrow path with the branches of the trees hanging so low that we had to hold our hats in front of our eyes to protect them from injury. Nor was it easy to do this, for the car bumped over so many stray clumps and hollows 
that we were frequently jolted out of our seats. And then we came to a little ditch before which our driver stopped just in the nick of time, and it required much patience, ingenuity and energy before we arrived safely on the other side. But our hindrances were not yet over, for we next came among a flock of sheep whom we had no desire to slay, and were then impeded by a scared jackal, who persisted in running for some hundreds of yards straight ahead of our car, despite our united shouts, until finally impelled to flee to one side. The second route proved altogether much worse than the first, and when, upon reaching our destination, I learned the amount of the fare, I offered up a silent prayer for the immediate construction of a railway or at least of an electric tramway from Jaffa to Petach Tikvah.

\section{2}

The next day I drove to Rishon-le-Zion, probably the most famous of all the colonies by reason of its plentiful production of wine. Although its name implies that it was the first colony to be established, its foundation followed that of Petach Tikvah, and it is smaller in area than the latter, having only I4,000 dunam under cultivation. I had a note of introduction to Mr. David Lubman, who has been head of the colony for fifteen years, and by a happy coincidence, when I reached the big square in front of the synagogue, his son was the first person of whom I inquired the way. Mr. Lubman was at Rishon throughout the period of the war, with the exception of the month that he spent in the Jaffa prison with the other members of the council of the colony. Their imprisonment, by order of Djemal Pasha, was due to the discovery that espionage had been carried on in the interests of the British Army. One young Jew of Rishon who had been proved guilty was hanged in Damascus, and all the members of the Rishon council were threatened with a similar doom. Prayers for their release were offered up daily by a number of women, 
who poured forth passionate lamentations among the tombstones of the cemetery, until at last, after four weeks of despair and suspense, the liberated men returned to the colony and were welcomed with transports of joy.

Before this disquieting episode took place, Rishon had basked in the favour of Djemal Pasha, who was greatly pleased with its progress and prosperity. He placed at the disposal of the Jewish settlers 20,000 dunam of dunes between the colony and the coast for the purpose of afforestation, but after 500 dunam had been planted with eucalyptus, firs and pines, and Djemal Pasha had fled northward, the effendis protested to General Bols, who ordered the work to be stopped.

"The whole of the Arab agitation against the Jewish settlement in Palestine," remarked Mr. Lubman, " began with our cultivation of the dunes. The Arabs would do nothing with the land themselves, but were loud in their complaints that the Jews were taking it away. The Arabs have created nothing, they have only destroyed, especially the trees, which we have now to replace. On the other hand, they are benefiting greatly from our doctors. Many of them still believe in the power of charms and cameos, and if they have an injury they burn their skin round the affected part to heal it. The Arabs have no sense of communal solidarity such as we have : their bourgeois class exploit the poor just like feudal lords. The effendis spend much money upon fine horses, but you will seldom find any books in their houses. But as for the Arab people as a whole they are good and friendly, and I believe we shall get on well with them."

During the war the house of Mr. Lubman was a favourite resort of many British and Australian officers, and he spoke with pride of the friendship they had formed with the members of his family.

After an appetizing meal, during which we drank the celebrated local wine, Mr. Lubman's son conducted me to the famous "wine-cellars." The way led through a beautiful avenue of palms, familiarly known as "Lovers' 


\section{THE JOURNAL OF A JEWISH TRAVELLER}

Lane," which formed the picturesque setting of the banquet given to the members of the Zionist Commission soon after their first arrival in the country. There were few things that I saw in Palestine owing their existence to Jewish effort that impressed me so profoundly with the potentialities of the resettlement as that stately avenue of palms. It was a testimony to the efficient husbandry of the despised Russian Jew, and it was a thing of beauty.

There was an air of bustle in the wine-cellars, as active preparations were being made for the vintage that would be gathered the following month. The cellars, which are the third largest of their kind in the world, cover a huge area, and even a cursory inspection occupies a great deal of time. There are a. vast number of barrels and vats of various sizes, ranged side by side like rows of sombre houses, and many of which seemed to me as large as, if not even larger than the famous Heidelberg vat. We descended by a staircase into the very bowels of the earth, lighting our way with a shaded candle, and passed through narrow gloomy lanes flanked by gigantic square chambers, of which there are altogether 200. Everywhere there were workmen repairing the barrels, cleaning? the vats, or overhauling the machinery, and often perched at such a height that they looked just like flies on a jampot. Situated in the heart of these mammoth " cellars" is a palatial hall, which could probably contain the Queen's Hall of London and leave a margin around for: wheeled traffic. It was in this hall that 6000 British and Australian soldiers were entertained to a Christmas feast a few weeks after the Armistice. It must have been a banquet reminiscent of the days of Ahasuerus, The wine flowed in abundance, and, although "none did compel," the warriors drank until they could no longer distinguish between friend and foe.

At length we ascended the staircase and emerged into daylight, and then I was shown the distillery for the decoction of various liqueurs, and likewise the laboratory in which everything produced in these "cellars" was 


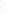




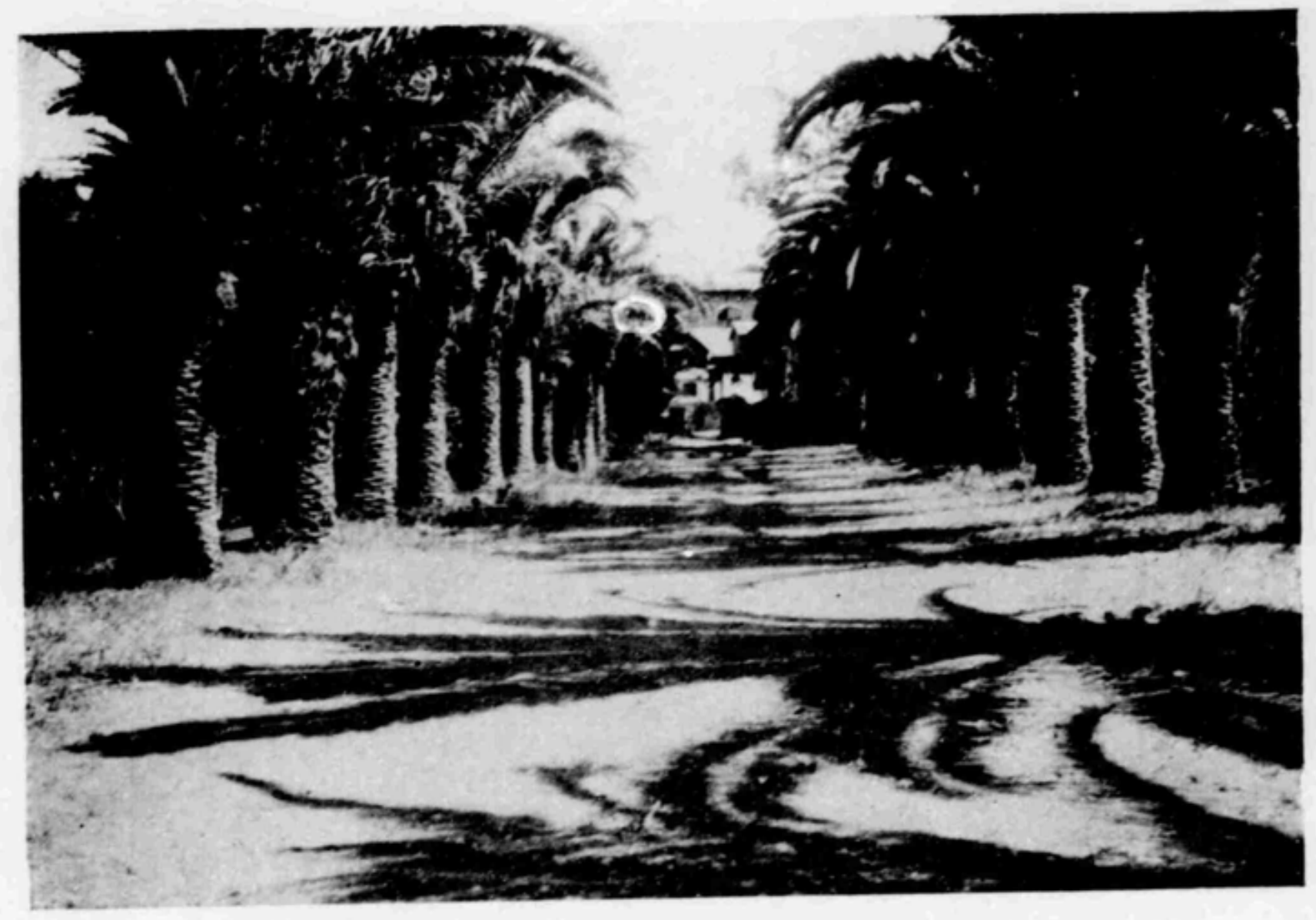

AVENUE OF PALMS, RISHON LE-ZION

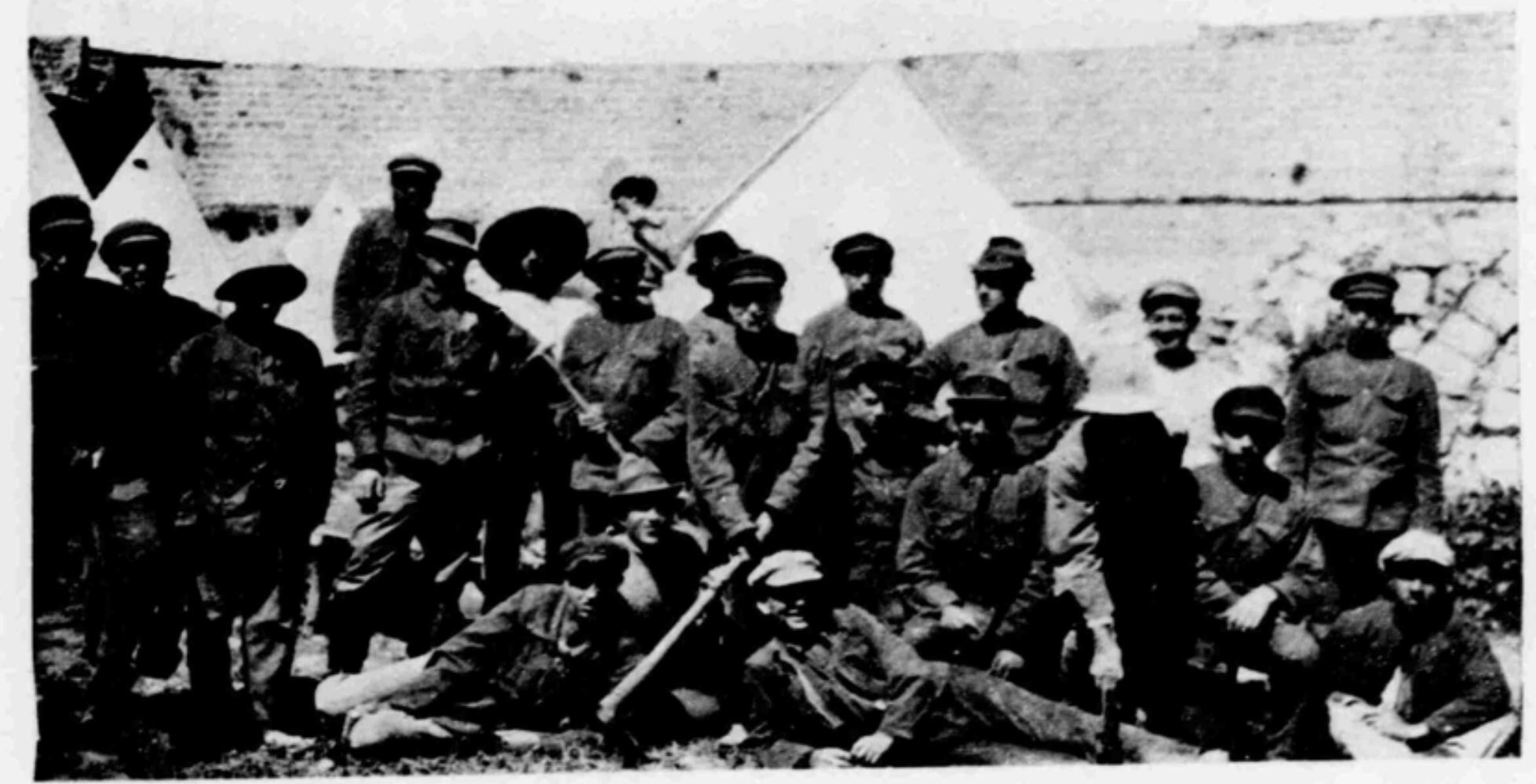

PIONEERS' CAMP, NEAR POOLS OF SOLOMON 
subjected to careful tests. Meanwhile the manager, Mr. Meyerovitch, had returned to the office, and he forthwith regaled me with some details about the business side of this great concern. During the harvest season, from June to August, 200 men were employed, and close upon 40,000 hectolitres of wine were produced per annum.

"In the chair in which you are sitting," he observed, "there sat a few weeks ago the English writer, Mr. Chesterton."

"And what did he say?" I inquired.

"I told him all about our work here, and asked him if he would like any further information, to which he replied that he was not interested in collecting facts."

" That's just the pity of it," I returned. " Chesterton always ignores the facts, except when he perverts them. He prefers to draw upon his imagination and is thus able to give free rein to his anti-Semitic prejudices."

On our return from the wine-cellars we were overtaken by the chief Shomer, ${ }^{1}$ who, mounted on a well-groomed horse, was going forth on patrol duty. We exchanged a Shalom, ${ }^{2}$ and he cantered away briskly, a sturdy resolute figure, symbol of the spirit of self-help that will be the mightiest factor in the restoration of the ancient land.

Before I left Rishon Mr. Lubman gave me a message to some former members of the colony who had migrated several years ago to Australia. "Tell them to come back now," he said. "A new era is beginning, and we need them all."

Half an hour's drive in a trap brought me to the little settlement of Nes-Zionah, which is also known by the Arabic name of Wady-el-Hanin. I alighted in order to ascend a hill, at the top of which was a bell to announce to the neighbouring population the hour for beginning work in the fields and the hour for ceasing, and whence I had a far-reaching view of the surrounding landscape,
1 Watchman.
2 Greeting (lit., " peace!"). 


\section{THE JOURNAL OF A JEWISH TRAVELLER}

with Rishon on one side and Rehoboth on the other. There was an air of peace and stillness over the scene, bathed in a pale blue light that was suffused with the golden tints of the setting sun ; but any tendency towards meditation was checked by the happy shouts of some boys and girls who were playing football below the hill and calling to one another in Hebrew. Football in the language of the Psalmists! What a wonderful span of the ages was conjured up by the bustling sight !

I resumed my journey, which now took me along a road that ascended gradually until the country beyond was hidden from view; but when we reached the highest point there spread out before us the picturesque approach to the plantations of Rehoboth. It is a smaller colony than either Petach Tikvah or Rishon, but it is equally flourishing. It was founded thirty-eight years ago by Mr. Eisenberg, who has zealously and prudently guided its development throughout, and it was to his house that I at once wended my way. Mr. Eisenberg has grown grey in the service of the colony, but he still devotes himself to its welfare with unabated vigour. When he first arrived on the site it was little better than a wilderness, where only Bedouins encamped. To-day, thanks to years of industry and careful cultivation, the property of the colony is worth $£ 800,000$.

The Vaad or council of Rehoboth consists of five members, who are elected annually by all the settlers, though the women, with flattering confidence in the efficiency of their menfolk, refrain from exercising their suffrage. Some members of the council have been reelected for the last thirty years, a testimony not only to their personal capacity but also to the communal harmony. As in the other settlements, so too in Rehoboth the council control the various public services, such as the water-supply, medical service, school, post office, public baths, security, and the relations with the Government authorities, whilst they also look after the synagogue. The security is in the hands of a special 
sub-committee, and is carried out by twenty watchmen and five mounted patrols by day, and by eight watchmen by night.

The colony, which contains I200 Jews, has an annual budget of nearly $£ 2500$, but this does not include the upkeep of the synagogue and the school nor the work of relief. It is the centre of the "Agudath Netaim" company, which was founded fourteen years ago by Mr. Eisenberg, with a share capital of $£ 75,000$, for the agricultural development of the district. The company paid $£^{2}$ per dunam for land, which, after improvement, is now worth $£ 6$ per dunam, and it can settle another 500 families on its present estates. The finest tribute to its system of management lies in the fact that many people have been in its employ since its establishment and now have farmsteads of their own.

"Under the Turkish fiscal system," complained Mr. Eisenberg, " only landowners and farmers were taxed : merchants, manufacturers and members of professions were exempt. As much as 35 per cent had to be deducted from the net produce of the land for the payment of taxes and local rates, and still the farmer could live very comfortably on the remainder. But it is manifestly unfair that the Government should impose a tax of I2 $\frac{1}{2}$ to I 5 per cent upon the land and give nothing in return. This is one of the crass instances of fiscal abuse, which British Administration should hasten to remove."

We then reverted to the object of my mission, and Mr. Eisenberg mentioned that several of the original members of the colony left it at an early stage for Australia, where they made a great deal of money, and afterwards returned to Rehoboth, bought land and houses, and have prospered ever since.

"Tell that to our fellow-Jews in Australia who are still hesitating whether they should come. We want them, we need them. Blessing and prosperity on your way!" 


\section{CHAPTER IV}

\section{FROM PORT SAID TO FREMANTLE}

FTER forty-eight hours of repeated inquiry and impatient waiting, of gazing at the ships of many nations that passed through the Suez Canal, and strolling through the streets of Port Said, with their alluring shops of Oriental wares proffered and praised by smooth-tongued, portly salesmen, I was told that my ship had come and was anchored opposite my hotel. It was a dark night, on the Ist of July, when even an experienced traveller might unwittingly be taken by the native boatmen to the wrong vessel, so I made doubly sure that I was ferried across to the Orontes, which was to carry me to Fremantle. Within half an hour I was on board, leaning over the ship's side and watching the swarms of natives below busily coaling. They looked like the denizens of some underworld, lithe dusky forms with a dirty cloth round their loins, emerging from big black barges with baskets full of coal, flitting with nimble feet across swaying planks, and shooting the cobbles into the bunkers with a thud, and then scurrying back again to the barges for fresh loads, whilst prodded ever and anon by the alert and menacing headmen, yet never ceasing from the quaint weird sing-song in a minor key with which they accompanied their labours. The scene was luridly illumined by the red glow of the braziers on the barges, whilst the monotonous chant rose aloft like the incantation from a wizard's cave. For hours the barbarous discord continued, thumping away at my brain, until it gradually lulled me to sleep.

When I awoke the next morning, we were well on 
our way. I found the Suez Canal surprisingly narrow, rendering our progress inevitably slow, but it had a compensating advantage, as we were near the land on either side, and thus able to see the places of historic interest that we passed. To me, and especially because of the mission upon which I was bound, this region made a romantic appeal, for it was the scene of epoch-making episodes in the early annals of Israel, of the Exodus and the crossing of the Red Sea. Four thousand years ago the Children of Israel had passed by here in their march to the Promised Land, and I could glimpse the sites of Succoth, Etham and the Bitter Wells, where Moses and the multitude of Pharaoh's liberated serfs had halted on their famous journey; and now, after a glorious and chequered history of national independence, exile, persecution and world-wide dispersion, the day had come when the descendants might once again enter the land of their forefathers and renew its former splendours. For the Peace Conference had solemnly declared for a Jewish National Home in Palestine, and the momentous pronouncement was celebrated by Jewry in all parts of the world with an outburst of joy that seemed to herald the end of the long exile. But the building of the National Home presented the same difficulty as the erection of the storehouses of Pharaoh : how could the builders make bricks without straw ? If all Israel were united in the will to restore the land, there would be a sufficiency of wealth for the purpose. But the wealthy of the West preferred the fleshpots of Egypt to the discomforts of the land for whose welfare they prayed from afar ; and those who once were wealthy in the East had been impoverished by the Great War and its innumerable brood of disasters. Hence measures had to be devised for raising money among all the Jews in the world, even those in the remotest parts ; and thus I was sailing to the communities in the Antipodes, whence I was to visit those in the Far East and India, to explain, to appeal, to wheedle, to beg, and to collect. 
The voyage to Australia was without any notable incident, though not without a variety of experiences. The heat in the Red Sea was oppressive almost beyond endurance, for though I sat in the lightest of clothing in a shaded deck-chair, and moved as little as possible, I had constantly to mop the sweat on my brow. A week after leaving Port Said, and when Cape Guardafui, too, was behind us, we suddenly encountered the muchdreaded monsoon. It came upon us with a howl one night, towards the end of a fancy-dress ball, when passengers and officers were all elated by the rollicking revels. Some of the gay costumes were drenched by the waves, and we all fled helter-skelter below deck. The ship rocked and tossed, groaned and writhed. With difficulty I made my way to my cabin, holding tight, so as not to be flung from side to side; and for the next two days I lay on my back motionless and helpless, listening to the straining and creaking of the ship, and thinking whenever there was a violent lurch that we were beginning to sink, and that my mission was doomed. But as the steward visited me at regular intervals, and I heard occasional voices on the stairs, I realized that my fears were groundless. We weathered the monsoon without mishap, but not without loss of time, and it was not until the thirteenth day after Port Said that we reached Colombo.

Nothing could have been more welcome or exhilarating, after the tedium of our voyage, than the day's stay amid the enchanting surroundings of Colombo, with its luxuriant vegetation, its refreshing expanses of green meadow, its endless avenues of lofty palms, and its wealth of brilliant colour. What have the Cingalese done to have deserved such a beautiful country, I thought; and why should it be such a paradise in comparison with the Holy Land, which had conferred such blessings upon civilization? Yet the people of Ceylon were apparently not without a thought for Palestine, for I was given a leaflet containing a special service of prayer to be offered 
up in the local churches, both by British and natives, for the welfare of the Promised Land under the new dispensation. But as one of the prayers bracketed the Jews with Turks, infidels and heretics, and as a footnote expressed a longing " that they may behold and worship the King of Peace in the Zion which He has chosen for His habitation," I was rather doubtful of the virtue of the entire service. Apart from this intended spiritual aid, however, I could find no material support in Colombo for my mission, as there were no traces of Jews living there. Nor, to be quite frank, had I enough time to seek any, for there was no organized Jewish community, and the few hours at my disposal were quickly spent in visiting Mount Lavinia, the Galle Face Hotel, a Buddhist Temple, where the guide showed me many large idols, as well as in bargaining with some native shopmen, and indulging in my first experience of a rickshaw. I admired the ease and speed with which the half-naked coolie rushed me along the road, and wondered still more at his apparent anxiety to do so.

From Colombo our progress was even slower than before, as, in addition to the south-west trade winds that we encountered, we had shipped bad coal. There was a gradual decrease in the temperature, which involved a corresponding increase in clothing, and there was also a perceptible increase in the monotony. Before Colombo we at least received a wireless message every day, giving the most important news; but now we gazed at the green-baize notice-board day after day in vain. There might be further wars and revolutions, Ireland might have got Home Rule, and the Russian Soviets might have been swept away; but we sailed on in profound ignorance, our only intellectual exercise being the vigorous betting on the ship's daily mileage, on which so many of my fellow-passengers, Australian and New Zealand officers returning home from the war, hopefully staked their bravely earned shillings. At last a message was received from the wireless station on the Cocos Islands 


\section{THE JOURNAL OF A JEWISH TRAVELLER}

five miles away, which we could view distinctly through our glasses, and we hastened breathless to the noticeboard to read it. "Beckett beat Burns" was the soulstirring tidings that greeted our gaze. That was the only news that reached us from the outside world during the eleven days of our passage from Colombo to Fremantle ; but it was better to hear even of that futile fight than of some fresh war.

The sea grew rougher daily, and the south-west trade winds drove mountains of black raging waves against our ship, which rocked at the thunderous impact, and set me wondering whether those who composed songs about the romantic life on the ocean billows had ever been beyond Margate.

Two days before we reached Fremantle a personal message reached me. It was a note of welcome from the Rabbi of Perth, brought to me in a closed envelope by a messenger, just as a telegram might be on land, and I realized for the first time the boon and wonder of wireless telegraphy. 


\section{CHAPTER V}

\section{THE PERTH CAMPAIGN}

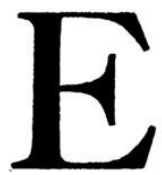

VEN before the Orontes reached the harbour I received the first personal greeting from a member of the Jewish community of Perth. He was an immigration official, who entered my cabin at six in the morning and roused me from my peaceful slumber to give me the first Australian "Shalom Aleichem !"1 He told me briefly of the preparations made for my visit, and then asked: "How much do you think you will get in Perth ? Five hundred pounds ?" In the words of a famous statesman, I bade him: "Wait and see."

My first impression on landing was not that I was twelve thousand miles away from England, but that I had reached an unfamiliar part of England itself, for everything around me was English-faces, language, shops, fashions. Hitherto I had not travelled more than a few hours by sea from London without coming to a foreign soil, a strange tongue and curious customs; now, after traversing half the globe, I had reached the same kind of people, modes and manners as those of my native country. This sameness of social phenomena annihilated all sense of distance.

The Rabbi, Mr. D. I. Freedman, who had left Jews' College in London only a few months after I had entered it, and who had remained faithful to the Perth Jewish community for nearly twenty-five years, headed a small deputation, who gave me a cordial welcome. But before leaving Fremantle I had to pay a visit to

$$
1 \text { "Peace unto you." }
$$

D 


\section{THE JOURNAL OF A JEWISH TRAVELLER}

the Customs officials, who demanded duty upon the two dozen Zionist flags which I had brought for presentation to the various communities included in my itinerary. My pleas to secure exemption, on the ground that the distribution of these flags would indirectly benefit British interests in Palestine, were of no avail; the officials pointed to their printed regulations and were inflexible. So a member of the deputation paid the duty upon one flag, which was retained for presentation in Perth, and the rest were left with the officials, to be forwarded to the Federal Customs Authorities in Melbourne, in the hope of a more generous decision. But this hope was doomed to disappointment; there was no loophole of escape from the rigid and detailed enactment. A duty of $33 \frac{1}{3}$ per cent had to be paid upon every Zionist flag that I distributed in the Commonwealth for the advancement of the welfare of Palestine.

We drove to Perth through the beautiful King's Park, and stopped for a few moments to examine a monument erected to the memory of the Jewish soldiers of West Australia who had fallen in the Great War. It was a tall marble column, which had been unveiled only a few weeks previously, before a vast and reverent throng, by the Governor of West Australia, and it was the finest Jewish memorial of the kind that I have ever seen. As we reached the city I felt that we were arriving in an English provincial town, with all the monotonous tranquillity of a provincial Sunday.

Perth has a Jewish community of about two thousand souls, of whom the greater part have emigrated from England, and not a few were born and suffered in Russia. The Agent-General for West Australia in London had told me that they were mostly poor, and that it was vain to expect from them any financial support, but I found that his knowledge of the Jewish conditions in the state that he represented was grotesquely obsolete. Although there was, as Moses had long ago predicted, a certain number of poor, they formed a very small fraction of the 
community, which, on the whole, enjoyed a fair degree of comfort. The principal stores and many big shops were in Jewish hands; there were prosperous manufacturers and merchants, successful professional men, and a host of small traders and artisans. But, what was equally if not more important, the community was endowed with a sound Jewish consciousness and with generous sympathies and even with sufficient enterprise to run a monthly paper of its own. Its moral and spiritual quality was a testimony to the zealous ministry of its Rabbi, who laboured in isolation, a thousand miles away from the next community. It was largely due to the calibre of Perth Jewry that the mission upon which I had entered with such diffidence was given so promising and stimulating a start.

An elaborate programme had been arranged for the three and a half days spent in the city-meetings and receptions, luncheons and lectures, calls and collections. It was the first occasion in the history of Australia that a Jewish emissary had come from the Old World, and the importance of the event-a reflex of the unique decision of the Peace Conference-evoked an intelligent and friendly response. My first welcome was in the Zionist Hall, where I was greeted with the familiar strains of Hebrew song by young boys and girls decked out in the Zionist blue and white and waving little Zionist banners. It was a social gathering rather than a public meeting, with an abundant leavening of mothers and children, whose enthusiasm-enhanced by the gift of the Zionist flag-set the note that was maintained throughout my stay. The most striking element was a group of Jews who had lived in Palestine for some years before the war and were compelled by the depressing conditions of the Turkish regime to emigrate, and who now, after having accumulated some savings, were anxious to know whether the time had come when they and their families could return. They inquired eagerly after some old friends in the Judean colonies. 
The principal meeting was held the same evening in the Town Hall, when, before a larger assembly both of Jews and Gentiles, I read a number of messages from Sir Herbert Samuel, Lord Rothschild, Sir Alfred Mond, Lord Robert Cecil, Dr. Weizmann, Mr. Sokolow and others, and then explained the sequence of circumstances that had preceded and occasioned my visit, and indicated the purpose to which it was mainly directed. I pointed out the place that Palestine had always held in Jewish memories and aspirations, how all efforts to secure its restoration to the Jewish people had hitherto failed, and how a wonderful evolution of events-unforeseen even by the boldest of seers-had now brought this romantic and century-old ideal within the realm of realization. The Great War, which had wrought such suffering and desolation among the teeming Jewish communities of Eastern Europe, had also yielded the means whereby Jewish suffering in future could at least be lessened if not utterly assuaged. Palestine had been redeemed by British forces, Great Britain had given a declaration that she would assist in the establishment there of a Jewish National Home, and the Allies assembled at the Peace Conference had solemnly endorsed that pregnant statement. A beginning had been made with the appointment of a Jew of avowed Zionist sympathies as the Governor of Palestine, but the actual conversion of the land into a Jewish country would depend less upon him or upon any administration, however philo-Jewish, than upon the Jews themselves. For the land that had lain desolate for centuries needed men and money for its rejuvenation. There would be Jews enough to flock to its shores, for during the last eighteen months there had been an unparalleled cyclone of outrage and massacre raging among the Jewries of Eastern Europe, which had swept away nearly I50,000 souls in 600 towns, and the survivors of the plague were yearning and gasping for a safe refuge in the Holy Land. But would there be enough money? Millions were required for the transport 
of the needy settlers, for the building of hostels, houses, schools and hospitals, for the purchase of land and its cultivation and irrigation, for the construction of roads and harbours, and for the execution of the noble project of a University of Jerusalem. For centuries the Jews had prayed for the rebuilding of Zion "speedily in our days"; now they had the opportunity of proving their sincerity and realizing their wish. If everybody would only give according to his means, enough would be forthcoming to achieve the glorious end. But if this unique and crucial moment were allowed to pass unused it might never occur again, and the soulless children of modern Israel would become a by-word and reproach on the lips of generations yet unborn.

No attempt was made that night to start a subscription list. Rabbi Freedman thought it advisable to give his congregants time for reflection, and arranged that the list should be opened the following evening in the synagogue. Meanwhile the Municipal Council accorded me a civic reception, at which I dwelt upon the magnifcent part that had been played by the Australian troops in the redemption of Palestine, and emphasized the importance to Australia of that land coming under British control, for thus would be ensured the uninterrupted connection between the mother country and the Commonwealth. Hence, the colonization of Palestine by a loyal Jewish community was of direct interest to the Antipodes. I remarked that I had come to revive a former Australian industry-the export of gold, whereat my auditors laughed and drank success to my mission. A few hours later I addressed the committee of the Hebrew Congregation who were assembled in a café, and appealed to them to set the community an example of generosity.

The gathering in the synagogue was surprisingly large, considering that its purpose was so widely known; there were not only men, but women and children, and, what was more gratifying still, the latter did not remain mere passive spectators, but took a keen and active part 


\section{THE JOURNAL OF A JEWISH TRAVELLER}

in the proceedings. Everything depended upon the amount of the first donation that would be announced, for that would set the standard of all subsequent gifts, determine the community's total contribution, and thus affect the response of all the other communities in Australasia. It was this vital aspect of the evening's proceedings that I emphasized in the address I gave from the puilpit, dwelling again upon the unique character of the opportunity that now lay within the grasp of the Jewish people. Of what worth were all the prayers poured forth in that shrine for the restoration of Zion if they found no outlet in the material sacrifice necessary for that end ? I repeated my appeal with varied argument, and called for a donation such as had never before been given in the community's history, for I had come, not for a charity, but for the greatest of Jewish national causes. I asked for $£$ Iooo. A look of astonishment spread over some faces, of ill-concealed amusement over others.

"I ask for a thousand pounds !" I cried again, and to coax any rich but reluctant sympathizer I suggested the amount could be paid in four years-one-fifth now and the rest in four annual instalments. "Surely," I pleaded, "somebody must have intended giving two hundred pounds. Multiply that by five and give one thousand pounds."

There was a pause for a moment, and my eye swept over the assembly. Suddenly an elderly gentleman rose, and, amid breathless silence, announced that he would have pleasure in giving the requested amount if five other persons would give similar sums. I thanked him for his generous offer, and begged him, for the honour of the cause, to withdraw the condition. He graciously assented, and at once the stillness of the sacred edifice was broken by such vigorous applause as had never been heard within its walls before. His name was Mr. Louis Seeligson; he set an example that proved infectious and sealed the success of my first appeal. The second response was for $£ 500$, the third 
for $£ 300$, and then came an almost uninterrupted series of calls in a slow downward gradation, young stewards taking the signature of each successive donor, whose name and amount were announced by the treasurer from the Almemar. ${ }^{1}$ The calls were so rapid that the secretary could scarce note them down quickly enough -now from the right, now from the left, now from the ladies' gallery above, and now from some schoolboy behind. At ten o'clock, less than two hours after this eventful meeting had opened, the total exceeded $f 8000$. Rabbi Freedman and I then hastened to the office of the Western Mail, and handed the night editor a brief report of the proceedings, with a complete list of the donations, which was published in the issue then going to press.

The next two days were busily devoted to supplementing the list. The Rabbi and I called upon all the members of the community who had been absent the previous night, determined to raise the total to $£^{10}, 000$. We had a few disappointments, but for the most part our visits were fruitful. Within little more than three days after my arrival the sum of $£$ ro,00o had been raised, payable within four years, and the committee resolved that 30 per cent should be earmarked for the creation of a new colony in Palestine to bear the name of Australia, expressing the hope that a similar quota of all subsequent donations raised in the Commonwealth would be assigned to this project. The result was telegraphed to Melbourne and Sydney, pour encourager les autres, and a telegraphic inquiry came back, "Was there not a nought too many ?"

The Governor, whom I visited, showed great interest in my mission, and expressed pleasant surprise at the success of my initial appeal. The Premier likewise evinced his friendly sympathy, and entertained me to lunch in Parliament House. It was a happy little gathering, at which the Speaker, the President of the Council, the leader of the Opposition, and Mr. McCallum Smith,

1 Reading platform. 
M.P. (of the Sunday Times), were present, as well as Rabbi Freedman and Mr. E. Masel, J.P., the treasurer. After lunch the Speaker conducted me past a row of portraits of his predecessors to the Chamber over which he presided, made me sit in his awe-inspiring chair, and delivered a mock oration from the Government benches in which he indignantly protested against a supposed anti-Semitic diatribe by an honourable friend in the Opposition. This humorous interlude over, I was taken by the President of the Council to his more austere Chamber, in whose solemn atmosphere such a jest would have been sacrilege.

At the hotel at which I stayed, and which holds a fond place in my memory because of the homely fire of pine logs on a spacious hearth in my room, I made the acquaintance of the famous pianist, Mr. Benno Moiseiwitsch, who was touring through the Commonwealth. He manifested keen interest in the future of Palestine as a Jewish country, and surprised me by asking whether he could not change his Russian citizenship for Palestinian nationality. I told him that the acquisition of Palestinian nationality would depend upon residence in the country, and he expressed a desire to visit it at the earliest opportunity. I also met the pianist's father-in-law, Mr. Kennedy, a tall, distinguishedlooking man, who told me that he was deeply interested in the history of the Jews, and had performed the heroic task of reading through Whiston's Josephus twice.

There was another Jewish celebrity of a different category whom I met in Perth-the actor John Lawson, an artist of generous emotions, but rather crude and extravagant methods, who, with his sketches, "Only a Jew" and "Humanity," upheld the name of Jew on the music-hall stage. He attended one of my meetings, and came up to me when it was over. I had last seen him nearly twenty years ago at an East End music-hall, in one of his characteristic scenes, in which the hero smashed a quantity of glass and crockery, and brandished the 
chandelier in his frantic effort to escape from the villain's diabolical snare. He was now looking rather thin and sickly, and a few months later he responded to the last call.

On the night of my departure there was the annual ball of the Jewish Congregation. The ballroom presented a gay, motley coloured spectacle, with fairylamps arranged like the "Shield of David," and many of the dancers whirling past in fancy dress. The wives of some Cabinet Ministers sat on a dais, whence they were to judge which were the best costumes. I was astonished to observe that nearly half of the guests were non-Jews.

"That is generally the case at our Jewish balls in Australia," remarked a leading member of the community with a worried air. "Intermarriage is one of our most besetting evils; few Jewish families can escape it."

In an adjoining room were the festively decked tables laden with tempting viands and delicacies, and tricked out here and there with the Zionist colours. In the middle of the head table there was a gargantuan plaited loaf, adorned with the "Shield of David," and there was a brave array of iced cakes with similar symbols. I could take only a snack, for the Trans-Continental train by which I was travelling to Adelaide was leaving at ten o'clock. On the platform the Rabbi and a group of friends gave me numerous messages to relatives at Kalgoorlie, Melbourne, Sydney and many other places that I should visit, and as the engine shrieked and throbbed they struck up, "For he's a jolly good fellow!" 


\section{CHAPTER VI}

\section{ACROSS T HE AUSTRALIAN DESERT}

T one o'clock the following day the train steamed into the Kalgoorlie Station, where a group of a dozen Jews were waiting to welcome me. They had been advised of my coming from Perth, and as there was an interval of three-quarters of an hour before I could continue my eastward journey they profited by the occasion. They had reserved the sole table in the refreshment-room for my formal reception, and upon it, decked with a white cloth and diffusing an air of festivity, there was a display of wine, cakes and fruit. They formed the entire male Jewish population of the town (their womenfolk were busy at that hour), though only a few years ago they had numbered over a hundred, the dwindling being due to the decline of gold mining in the district. Most of them were of Russian origin, but all were keenly interested in the object of my mission and begged for a speech. Briefly I explained the situation in regard to Palestine, and appealed for their support, which was readily promised. Upon the proposal of the oldest member, a sturdy grey-beard, we drank to the success of "The Jewish National Home," and several short but enthusiastic speeches followed. It was agreed to raise a local fund and send the money to Perth, of which Kalgoorlie, though fifteen hours distant, seemed to be regarded merely as a suburb. The Jews who had formerly lived in this mining district, I was told, had all gone back to Perth, and those who still remained would also return after they had disposed of 
the fate of the synagogue which had been built in expectation of a permanent community.

We walked back in a body to the platform, my new friends plying me all the time with questions about the prospects of immigration into Palestine. Then I took my seat in the long Trans-Continental train, which presently began to move, bringing to an end the happy interlude.

The next two days and a half were spent in crossing the Great Australian Desert. The journey was not unpleasant, for the train was furnished with all the comforts and conveniences one could reasonably demand : dining-car and sleeping-berth, lounge-car with cosy arm-chairs and writing-desks, a drawing-room with a piano, and even a shower bath. We first passed through flat timbered country covered with salmon gums, eucalyptus trees and the odoriferous sandal-wood, and then through a vast limestone plain, where the only vegetation consists of the saltbush and the bluebush. For hundreds of miles we saw nothing but these low bushes, seldom rising above three feet, with their greyish green and bluish white colouring. The line runs through Nullarbor Plain, which is so truthfully named, for 300 miles without a curve, probably the longest straight stretch of railroad in the world, and for hours we could follow the gleaming twin rails and see them dissolving into one another in the distance. Every few hours the train stopped at a primitive station, where one or two families lived, for the pumping of water, and we all promptly availed ourselves of the opportunity of jumping out and stretching our limbs. On one occasion, when we were near some woods, we saw a few copper-coloured aborigines of low mental type, a burly bearded man with a tousled mop of hair, and a young girl carrying a child, shyly approaching. They begged for pennies, and got not a few, especially the man, who showed his prowess in plunging his javelin into a tree twenty yards away.

Among my travelling companions were two or three 


\section{THE JOURNAL OF A JEWISH TRAVELLER}

Commonwealth celebrities. One was Mr. Jack Wren, an Irish politician of Sydney, who had raced across the Continent to Perth in the hope of rescuing a German Catholic priest, Father Jerger, who had been put by the Government on a ship bound for Europe, and was now returning-after having vainly reconnoitred in a boat off Fremantle-with his two athletic henchmen, a sadder and a wiser man. There was a Jewish pugilist named Stone, who had won a fight at Perth; and there was a member of the Federal Parliament, who had the privilege of a free pass, for the railways in Australia belong to the State. But I chatted mostly with a young clergyman, Mr. Riley, who had been a chaplain in Palestine during the war. He entertained me with stories of his personal experiences, as well as about his father, the unconventional Bishop of West Australia, who often performed a christening at a wayside station, to which a mother would bring her baby in a dog-cart from some lonely farmstead a hundred miles away.

On alighting in Adelaide Station, just three days after leaving Perth, I was welcomed by the President of the Jewish Congregation, Mr. M. J. Solomon, the minister, the Rev. I. A. Bernstein, and all the members of the committee. I had first announced my intended arrival by a cable from Colombo, and afterwards wrote a letter from Perth, but from what I heard in the latter city about the essentially English character of the Adelaide community I was rather diffident about my prospects. But the cordial greetings that I received from the large deputation immediately reassured me, and their first act upon reaching the hotel at which I was to stay, banished all doubts. For after I had given them a brief and cursory explanation of my mission, as we sat in the smoking-room, they left me for a few moments to confer together whilst I was being interviewed by a pressman ; and upon the conclusion of their deliberations the President, a hale octogenarian, who had occupied his office for forty years, informed me that the committee had voted 
EIoo from the funds of the congregation to head the local list.

The Jewish community of Adelaide is one of the oldest in Australia, and although numbering only about 500 souls altogether, it can boast of a very fine record of municipal service. Many Jews were among the pioneers of South Australia, the most distinguished being Jacob Montefiore, a cousin of Sir Moses Montefiore, who was selected in 1835 by the British Government to act on the first Board of Commissioners of the Colony. Jews have acted as mayors of the city, which was incorporated only eighty years ago, for an aggregate of thirteen years, a period out of all proportion to their numbers, and at the same time a testimony to their popularity and administrative capacity. The first Jewish mayor, John Lazar, held office as far back as I855. The longest record is that of Alderman Lewis Cohen, ${ }^{1}$ who has occupied the mayoral chair for six years, and who was selected by the municipal Council to present an address to the Prince of Wales on the occasion of the recent visit of the latter to unveil a statue of the late King Edward. The highest dignity in the colony achieved by a Jew was that of Premier, which was held in 1899 by the Hon. V. C. Solomon, who performed much useful service in exploring the vast Northern Territory.

Owing to the brevity of my stay I addressed only one meeting. It drew a very large attendance, and the financial response was satisfactory, one notable donation coming from a Christian sympathizer who was present. But what added to the value of the gathering was the fact that a Zionist Society was established, which I regarded as an earnest of regular support in the future. Its formation was largely helped by the enthusiasm of the minister and of one or two Jews who had already lived in Palestine.

Shortly before my departure I called upon the Governor, Sir Archibald Weigall, to pay my respects. He was

\section{Now Sir Lewis Cohen.}




\section{THE JOURNAL OF A JEWISH TRAVELLER}

keenly interested in the development of Palestine, he told me, for he knew Sir Herbert Samuel well, and had served with him on a Government Finance Commission during the war. He was surprised when I told him that a distinguished predecessor of his, Colonel Gawler, the second Governor of South Australia, occupied a notable place in the history of British schemes for the restoration of the Jews to Palestine, and he promised to look up the career of that zealous lover of Israel. 


\section{CHAPTER VII}

\section{MEMORIES OF MELBOURNE}

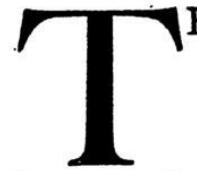

$1^{\mathrm{HE}}$ journey from Adelaide to Melbourne, accomplished overnight in a comfortable train, was the shortest I made since I left Port Said, impressed me as a beautiful city, clean and spacious, with wide, regular streets, tall imposing buildings, including something like a sky-scraper, and a handsome tree-lined thoroughfare-St. Kilda's Avenue-which can challenge comparison with some of the finest boulevards in the capitals of Europe. It has a Jewish community of 6000 souls, who are all intensely proud of the city in which they live, and who never ceased asking me what I thought of it. Their lines have fallen in pleasant places, for most of those who arrived there as immigrants with only a few shillings in their pockets, though with untold energy, succeeded within a comparatively short time in attaining a high degree of prosperity. One of the largest departmental stores was pointed out to me as belonging to a Russian Jew who, twenty years ago, went about hawking with a pack on his back. The devotion of the Jews to the British Crown is sincere and ever-present, and struck me as much more demonstrative in character than that of their co-religionists in the mother country. So fond were they of singing the National Anthem at the gatherings in which I appeared that I was almost inclined to think that they regarded me not so much as an Emissary of the Zionist Executive as an Envoy of His Majesty.

On the day of my arrival a reception in my honour 


\section{THE JOURNAL OF A JEWISH TRAVELLER}

was given by the committee of the " Hatechia," a Zionist Society consisting mostly of Russian Jews. As I entered the room the entire company greeted me with "God save the King," to pianoforte accompaniment, and after the introductions were over, and we had taken our seats at a festively decked table, the chairman asked us to fill our glasses, rose to propose "The Health of the King," and within two minutes the National Anthem was again rendered with great gusto to the tinkling of the piano. Many speeches, brimful of enthusiasm, were then delivered, and the concluding event was the singing of the National Anthem for the third time. That demonstration should have sufficed to convince even the most sceptical of the Morning Post scribes that Zionism has nothing to do with Bolshevism. There was, indeed, hardly any public function in my honour that did not either open or close with a similar patriotic manifestation. One evening I went to a ball organized by some youthful Zionists, and as soon as I appeared on the platform overlooking the dancing-floor, the orchestra suddenly stopped in the middle of a lively jazz measure, and after a moment's solemn preparation vigorously struck up the ever-popular anthem.

The reception on the day of my arrival was rendered memorable by another feature. It was a gargantuan plaited loaf that lay on the table. before me, similar to that which I had seen in Perth on the eve of my departure. It had been specially baked, I was told, not only in my honour, but for my personal consumption; but when I explained that I could not very well take the loaf back to my hotel, and that in any case it would become quite stale before I had eaten even half, it was proposed that it should be raffled among the members of the society for the benefit of the Palestine Fund. This suggestion, however, was not proceeded with, as one of the members bought it by private treaty for a party that he was giving the next day in celebration of his daughter's marriage. The bridal couple thought 
that their union was rendered particularly auspicious by the acquisition of the loaf of the Zionist Emissary.

Among various messages that reached me soon after the local newspapers published their first interview with me was a letter from a gentleman who stated that he was very keenly interested in my mission, and had indeed been looking forward for some time to my coming. He mentioned that he was the brother of a rather distinguished personality in London, and asked if he could call to see me. I at once responded cordially and affirmatively, congratulating myself upon the valuable assistance which I felt sure he would offer, and still more upon the introduction that I expected to receive to the distinguished London personality, who had hitherto held quite aloof from any Jewish cause. The brother of the great man came to see me at once, but at the first glance at his shabby coat and bristly chin I felt that I had been building castles in the air, and we had not been engaged in conversation many minutes before all the castles came toppling down into fragments. For my visitor, after inquiring after the welfare of his famous relative and perceiving that I acknowledged his importance, suddenly remarked: "I'm rather stumped just now. Can you lend me a dollar? I'll let you have it back when we meet again." I had little faith in the possibility of any such repayment, nor was I disposed to risk a second meeting, as I feared it might be abused by further exploitation, so I gave the brother of the distinguished personality half a crown, and he left me with the assurance that he would never forget me-a sentiment that I sincerely though tacitly reciprocated. When I related the incident later in the day to a friend, he told me that my experience was not unique, that there were several " ex-remittance men" belonging to good families of the old country, who were always on the look-out for visitors whom they could impress and impose upon; and he congratulated me upon having got off so cheaply.

But if I had to place a trifle on the debit side of my E 
sojourn in Melbourne, I was rather lucky to be able to build up on the credit side a record of munificence far surpassing anything done by any other community in the whole of my travels. I owed a good measure of my success to the help and advice of Mr. M. Zeltner, the President of the Victoria Zionist Organization, who was himself characteristic of the self-made man, for, born over half a century ago in Cracow, he had arrived in Melbourne with nothing but his wits and his grit, and gradually established his fortune as a merchant in rubber, and his fame as a public-spirited philanthropist. He presided at the first two public meetings that I addressed, and lent his house on a Sunday afternoon for a private gathering, the total yield of the three occasions being nearly $£$ I4,000, which Mr. Zeltner headed with the first $£$ I000.

The most important meeting was that over which General Sir John Monash presided. The General had hitherto not identified himself with Zionism, although, since his return from war-stricken Europe as the brilliant Commander-in-Chief of the Australian Forces, he had begun to take a more keen and active interest in Jewish affairs. The fame that he, not a professional soldier before the war, had deservedly won on the battlefield by his genius for strategy and gift for leadership, seemed to be resented by the military clique, whose jealousy prevented the according of such an official welcome on his home-coming as a victor acclaimed in the Allied capitals was entitled to expect. Sir John had now put away his uniform and sword and resumed his practice as a civil engineer, and only a day after my arrival he was appointed by the Federal Government as Director of the great Morwell electricity scheme. He was exceedingly busy at the time, and as the meeting over which I wished him to preside was to take place on a Monday evening, and I could not approach him until the previous Friday afternoon, I was prepared for a rebuff. But Sir John was the soul of kindness. He welcomed me in his 
. 


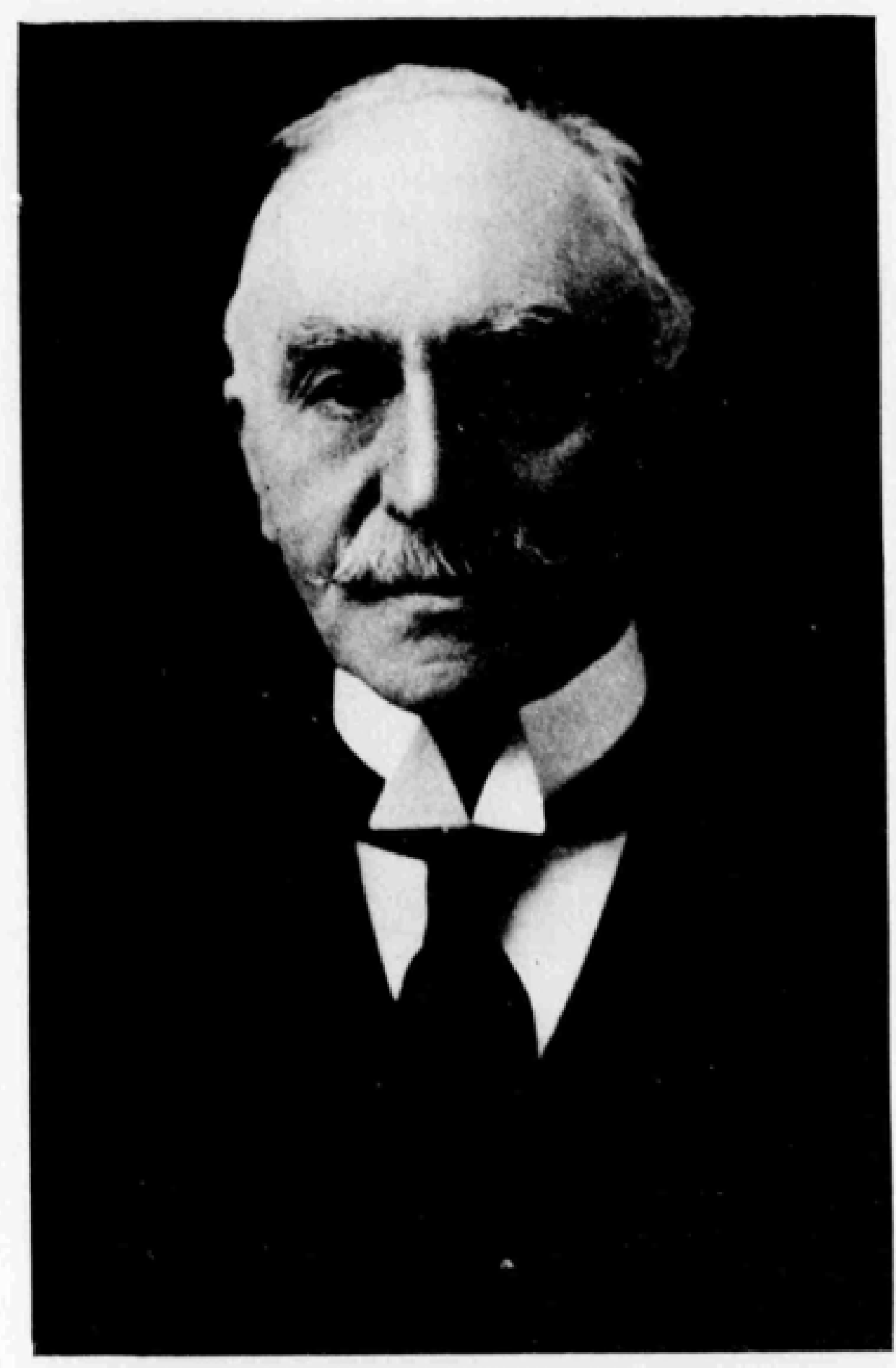

THE HON, JUSTICE ISAACS

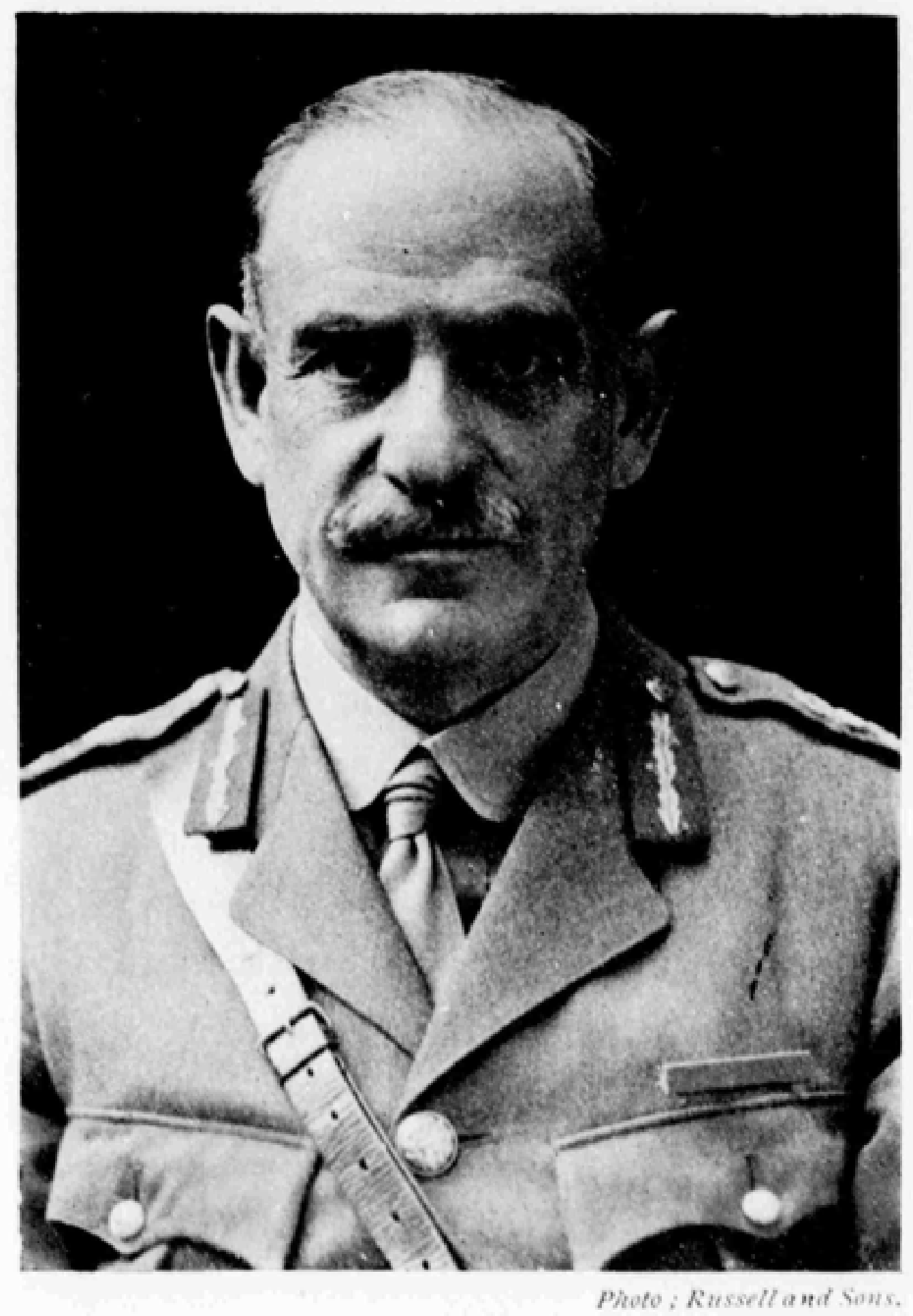

L.IEUT,-GENERAL SIR JOHN MONASH 
office in his bluff and hearty manner, and little persuasion was needed either from me or from a mutual friend, Mr. B. H. Altson, an ardent Zionist, who accompanied me, to secure his assent to our request. He had a previous engagement, an important meeting of the Court of Governors of the University, but he agreed to waive it for the sake of Zion. He inquired about the latest developments in Palestine, and told me with pride that a famous kinsman of his had once been interested in the Jewish colonization of the country.

"Who was that?" I asked curiously.

"The historian of our people, Graetz," was the reply.

There was little time left to make arrangements for the meeting, especially as it was the week-end, and some of my friends were rather nervous about the result. But thanks to prominent advertisements in the press, headed "The King's Message to Palestine," and above all, to the attraction of Sir John Monash, whose popularity with the public was not affected by military pique, the Assembly Hall was crowded with a representative audience of about rooo, whilst late comers had to be turned away. As soon as Sir John arrived in the waitingroom behind the platform he remarked: "I mustn't forget to give you this," and, taking a half-crown out of his waistcoat-pocket, he said : "This is from my cook. She is a profound believer in the restoration of the Jews to Palestine, and she insisted on my giving you her mite to the fund."

The meeting was marked by scenes of enthusiasm, particular applause greeting the reference in my speech to the part played by the Australians in the redemption of the Holy Land. I had been told that at the time when volunteers were being raised in the Commonwealth for transportation to the battlefields of Europe there was a popular song with the catching refrain: "Australia will be there!" which was sung and whistled throughout the Continent. I utilized the refrain in drawing a picture of the future glories of Palestine, for, speaking of the 
new settlements that would gradually arise to cover the waste places of the ancient country and of the proposal to create among them a colony bearing the name of the Commonwealth, I exclaimed that "once again would it be said: "Australia will be there!'" The patriotic allusion brought the house down. My appeal for funds, conducted by the method I had inaugurated in Perth, was successful. The first response was for $£$ rooo, then followed a few donations of $£ 500$ each (one being from Sir John, though he asked that the announcement should be anonymous), and scores of others for decreasing amounts, until a total of $£ 6000$ was reached within an hour, making a grand total of $£ 20,000$ after only six days' work. The Victoria collection was shortly increased to $£ 26,000$, thanks to private canvassing and to visits paid to Geelong and Ballarat.

Another distinguished Jew whom I met was the Hon. Justice Isaacs, a member of the Commonwealth Supreme Court, whose decisions in some leading cases, I was told, had evoked encomiums from legal authorities in England. $\mathrm{He}$ was another example of the Jew who had risen to the highest position by sheer merit and force of character. The son of a poor Russo-Jewish tailor, he had started life as a school teacher, but in his leisure hours he studied law and then decided to devote himself to the legal profession.

I met him-a dour-visaged sexagenarian of medium height with small grey moustache and fresh complexion - at the house of Mr. Altson. The aspect of Zionism in which the judge was most interested, or rather about which he was most concerned, was the question of Jewish nationality. He could not understand nationality apart from a state or territory from which such nationality was derived, and he therefore asked how the Jews, having no such qualification, could claim nationality. I replied that his definition was faulty, that it was formulated without regard to actual conditions, and that he confused nationality with citizenship. 
"Take the case of Eastern Galicia," I said. "There you have a country whose fate the Peace Conference has not yet decided, and which is inhabited by three distinct nationalities-the Ukrainians, the Poles and the Jews. The Ukrainians and the Poles are striving for the mastery, but both recognize that the Jews form quite a different nationality. Whatever be the fate of Eastern Galicia, the Jews will be citizens of the State to which it will be assigned, but they will still belong to the Jewish nationality."

The judge thought for a moment, and then said gravely: "I think that nationality is an unfortunate term."

He told me that he was making a serious study of Hebrew grammar, which he had neglected since boyhood, and wished to know something about the adaptability of Hebrew to the needs of modern speech, asking for the equivalents of various modern terms. The acquisition of languages was his hobby, and among the various European tongues that he had mastered were Russian and modern Greek. I was anxious that he should make a profounder study of Zionism than he had hitherto done, and was glad to learn that he intended visiting Palestine on his way to England, whither he was shortly sailing for a year's holiday. I gave him a letter of introduction to Sir Herbert Samuel, but when I reached Jerusalem several months later, I learned that Justice Isaacs had spent only a day in Palestine, which scarcely sufficed for the correction of pre-conceived ideas, still less for the gathering of new impressions.

Among the novel experiences that fell to my lot was to occupy the pulpit in two synagogues, first, at the more fashionable shrine in St. Kilda, whose minister was my old fellow-student, the Rev. Jacob Danglow, and, secondly (after a few weeks spent in New Zealand), at the East Melbourne Synagogue. The addresses served a practical as well as a moral purpose, for they were delivered during the Sabbath morning service 


\section{4}

THE JOURNAL OF A JEWISH TRAVELLER

before congregations which included many people who had not attended my public meetings, and the result was of no small benefit to the Fund. The experience recalled memories of my Jews' College days, when I occupied more than one London pulpit ; and apparently I acquitted myself of the preacher's rôle with some measure of satisfaction as I was discreetly approached on behalf of the committee of another synagogue and offered the vacant position of minister with alluring emoluments. Memories of my College days were also revived when I visited Mr. Danglow's study and saw on the wall the framed illuminated address that had been presented to him by the Jews' College Union Society on the occasion of his departure from England some sixteen years before, and which had been drafted and signed by me as President of the Society.

I had, indeed, no lack of variety of experiences. They were in no case exciting, though occasionally exasperating. For I had to supplement my public appeals by personal canvassing, and I seldom found anybody willing to promise a donation without some preliminary skirmish. Doubts were sometimes expressed whether the Zionist scheme would succeed; questions were asked about the measure of financial support given by prominent English Jews ; priority was claimed for local calls and charities ; attempts were made to postpone a decision. But I grappled bravely with every case, developing the patience of a Job and the ingenuity of a counsel for the defence. One man wished to be assured that there would be a Hebrew revival in Palestine; his next-door neighbour demanded that English should be predominant; both were ultimately satisfied and contributed. Another person was anxious lest England should relinquish the Mandate and leave Palestine to her fate; and a fourth had the vision of a powerful Jewish Commonwealth fifty years hence making war upon Great Britain-as though we Jews have not had enough with the wars of others. Some doubted whether Jews could make successful 
colonizers, but when I showed them some of the photographs I had taken in Palestine-of the beautiful avenue of palms in Rishon-le-Zion, the picturesque suburb of Tel Aviv, the keen intelligent faces of the Haluzim, the splendid figure of a mounted Shomer-their doubts were dispelled.

There was, in truth, little reason in Victoria for doubt on the score of Jewish fitness for husbandry, as a colony of Jewish farmers had actually been created in that State only a hundred miles from Melbourne. It was the fruit-growing colony of Shepparton, comprising a hundred Jews, mostly of Russian origin, some of whom had lived in Palestine several years before the war. The establishment of the settlement was due to the initiative and generosity of one or two public-spirited Melbourne Jews, and had proved thoroughly successful. I received a telegram from the little community inviting me to visit them, but unfortunately my arrangements rendered the journey impossible. The Jews of Shepparton, however, bore no grudge. They at once convened a local meeting, delivered speeches on the restoration of Palestine, and raised a goodly sum for the benefit of the Fund.

A little scepticism was also expressed at a meeting that I addressed under the auspices of the Melbourne University, and over which the Principal presided. I spoke mainly upon the subject of the Jerusalem University, though I also dealt with the general aspects of the Restoration. But a professor of history, who proposed the vote of thanks for my address, tried to show that the Zionist ideal was impracticable on the ground that his reading of history had taught him that the Jews had always lived in discord with one another, and could not govern themselves. I acknowledged his thanks but repudiated his history. I pointed out that the Jewish communities and colonies already established in Palestine were a model of peace and concord; and that the Jews were not only able to govern themselves, as they had 
proved through the councils of the rural colonies in that country, but were also able to govern some of the people in Australia, as would be shown when Sir Matthew Nathan shortly arrived to assume office as Governor of Queensland. The burst of applause evoked by this local illustration signalized the discomfiture of the professor and the explosion of his thesis.

Before leaving Melbourne, I had a brief interview with the Commonwealth Premier, the Right Hon. W. M. Hughes, to whom I bore a letter of introduction from Sir Alfred Mond. The Federal Parliament was sitting at the time, and as the interview was to take place in the Premier's official room, I arrived a little earlier so as to hear some of the speeches. The Chamber, which is modelled in general after the House of Commons, is, of course, much smaller and less dignified, and the apparently constant restlessness of the members deprived the proceedings of any inspiration. I was fortunate enough to come in time to hear "Billy" Hughes, as he is invariably styled, address the House on the Estimates. $\mathrm{He}$ has an unprepossessing figure, being short, roundshouldered, and with a beak-like nose; his lips snapped open like a vice, emitting a rasping, raucous voice, and then snapped together again; he gyrated first on one foot and then on the other; and all the time he held in his hand a short ear-trumpet to catch the interruptions that flew about. But the instrument did not compensate entirely for his deafness, and he made some curious slips in his retorts, which evoked peals of laughter. "Billy," however, was not disconcerted, and despite all his physical deficiencies he easily dominated the entire assembly with his arresting eye and air of authority.

As soon as his speech was over he left the Chamber for his private room, into which I was presently ushered. After reading the letter of Sir Alfred Mond, he remarked that the latter had been very helpful to him in England, and then asked if he could be of any assistance to me. I said that I should have liked him to preside at a public 
meeting, but as he had been away most of the time that I was in Melbourne, and I had to leave for Sydney the next day, that desire was doomed to disappointment. He inquired about the progress in Palestine, and especially about the attitude of the Arabs, and then sharply asked :

"You haven't come here to recruit emigrants for Palestine ?"

"Oh, no, sir," I assured him.

"Because we can't spare any," he added grimly.

He expressed his good wishes for the continuance of my tour, and I withdrew. 


\section{CHAPTER VIII}

\section{EXPERIENCES IN SYDNEY}

T $F$ there were any united organization of Australasian, or even of Australian Jewry, Sydney would doubtless claim to be its metropolis, for it has both the oldest and the largest Jewish community in the Antipodes, numbering over 8000 souls. But as there is a complete absence of such organization, partly on account of the great distance between the various cities, and partly on account of the friendly rivalry between the capitals of Victoria and New South Wales, the importance of Sydney Jewry is confined to itself, and is not reflected in the exercise of any influence beyond its own borders. Some of its members, indeed, have played a considerable part in their time. The two Montefiore brothers, Jacob and Joseph, cousins of the illustrious Sir Moses, who came to Sydney in the third decade of the nineteenth century, gave a powerful impetus to the economic progress of New South Wales. Jacob owned one of the largest sheep-runs in the State, and was the founder and director of the Bank of Australia. The gratitude felt towards those bold and sagacious pioneers was expressed in the naming of the township of Montefiore in the Wellington valley. But the racial loyalty that has characterized the Montefiore family in England failed to resist the assimilative influences of the young colony, and no representative has survived in Sydney Jewry, although the family name is perpetuated by a home for the aged needy, which was so denominated to give honour to the great philanthropist of English Jewry. 
In proportion to their numbers the Jews of Sydney have attained unusual distinction not only in the commercial, but also in the political world. As far back as I872 there was a recognized Jewish party in politics, which the contemporary press spoke of as " a recognized power in the State," and Mr. (afterwards Sir) Henry Parkes enlisted this power on his side by appointing Mr. (afterwards Sir) Saul Samuels " to be the representative of the Government, without portfolio, in the Upper House, and gazetted him besides to the office, which belonged to Mr. Parkes himself as Premier of the Parliament, of Vice-President of the Executive Council." Sir Saul Samuels, Baronet, was afterwards for several years Agent-General of the Colony in England. Other Jews who rose to fame were Sir Julian Salomons, K.C., who was for a short time Chief Justice of the Colony, and who also held the post of Agent-General in London, and Mr. Henry E. Cohen, who was a judge of the Supreme Court of New South Wales. Moreover, several Jews have been members of the Legislative Assembly at various periods during the last fifty years, and at one time both the Speaker and the Deputy-Speaker were members of the Jewish community, namely, Mr. John J. Cohen and Mr. Daniel Levy. This rare coincidence-a striking tribute to Jewish ability-proved rather awkward on one occasion, as in consequence of the desire of both the Speaker and his Deputy to attend the synagogue on the solemn Day of Atonement, the New South Wales Legislative Assembly had to adjourn for twenty-four hours-an event that has only one parallel in the history of British Parliaments. ${ }^{1}$

With such a record, and in view of the comparatively small element derived from Eastern Europe, I understood why Sydney Jewry was spoken of as the most English of the Jewish communities in Australia, and also why I was warned not to expect such a cordial

1 In 1849 the Legislative Assembly in Jamaica adjourned over the Day of Atonement out of respect for its eight Jewish members. 
response to my appeal as I had found in Melbourne or Perth. Accordingly, a number of public functions were arranged to precede the principal meeting, at which the Governor had consented to preside, in order that the doubtful sympathies of a part of the community might be subjected to the cumulative influence of various "ceremonial" addresses and the newspaper publicity these would inevitably receive. The first of these addresses was given at a conversazione at the Hotel Australia, where I was introduced to a representative gathering by Rabbi Francis L. Cohen. The speechmaking began rather late, as we had to wait for the Rabbi, who was solemnizing a marriage at the synagogue. It was quite customary, I was told, for the marriage ceremony in Australia to be held in the evening; and it was also becoming customary for the bride to be admonished not to appear too décolletée beneath the canopy, lest she would be bidden to retire and rearrange her corsage. When the Rabbi at last arrived, and our exchange of greetings was over, he described me as an old pupil of his at Jews' College, and said that-so far as Zionism was concerned-he was still sitting on the fence, but was open to conviction. In acknowledging the laudatory welcome, I explained that I had been a pupil of Rabbi Cohen in only one subject, the theory of music, and not a very apt pupil either; but the great lesson I had learned from him was the importance of harmony, and I therefore hoped to find this applied and realized in the response of the community to the message I had to deliver. The company was a critical one, but I was assured by my fellow-Zionists, who were by no means in the majority, that the point had gone home.

The following day I had the opportunity of addressing two different audiences, one of a commercial and the other of an academic character, and both consisting mostly of non-Jews. The first was at a luncheon given by the Millions Club, which comprises the leading business men of the city, and which is so called because it 
provides a forum in which men with a message of interest to millions can communicate it in a half-hour's speech. The Hon. Daniel Levy, who sat beside me, anxiously impressed upon me not to exceed the regulation limit even by a second, as the club had had some unfortunate experiences of verbose guests who had increased their allowance by 50 per cent and more, whilst their audience had diminished by a like proportion. The chairman, Mr. Arthur Rickard (who was knighted a few months later), uttered the usual panegyric upon the civic qualities of the Jew, and hoped that I had no intention of luring any of the Jewish citizens of Sydney to Jerusalem. I assured him that I should be quite content if they would all contribute the amount of the fare to the Holy City towards the Palestine Fund without changing their residence. The members of the club had no reason to complain of any misappropriation of time, as I concluded exactly thirty minutes after I began, just as the clock struck. two.

The other function of that day was a lecture in the University of Sydney on the University of Jerusalem, at which the famous geologist Professor David (who was also knighted a few months later) presided. As the Hebrew University had not yet emerged above the level of its foundation-stones I was unable, after giving a full description of the project, to show anything of it on the screen except the site on Mount Scopus. But Professor David afterwards remarked, amid the approving cheers of the audience, that the new capital of the Commonwealth, which had been begun so many years ago, also consisted so far only of foundation-stones, and he was confident that the University of Jerusalem would be completed sooner. A member of the audience, which included several adherents of the British-Israelite theory, asked, "What about the return of the lost Ten Tribes ?" to which I replied that the Zionist Organization was at present so busily occupied with the Jews already in Palestine, and with the tens of thousands who wished 
to go there, that it could not yet concern itself with those who had so far not reported themselves. After. the lecture two or three British-Israelites approached me and asked what they could do to further the restoration of Palestine, and one of them handed me a letter with Biblical quotations in carefully written Hebrew.

The Great Synagogue, the largest Jewish place of worship in Australasia, presented an unusually crowded appearance on the Sabbath morning in expectation of the sermon I was announced to deliver. The occasion was of interest to the congregation as well as to myself, as although nearly three years had elapsed since the issue of the Balfour Declaration, and grateful hosannas had meanwhile been voiced in most synagogues throughout the world, no reference to that epoch-making document-so I was told-had yet been made in the pulpit of the Sydney Synagogue. On the contrary, some tracts published by a "League of British Jews," which was created, rather paradoxically, for the purpose of blunting the effect of the British Government's Declaration, had been placed some months before on every seat, where the worshippers found them on their arrival, to the indignation of not a few. The anglicizing tendency of the congregation was manifested in the reading of the Haphtara ${ }^{1}$ in English by the Rabbi, although he chanted the blessings both before and after it in Hebrew; and an English note, too, was struck by the " mortar-board" and college gown in which I was arrayed for my appearance in the pulpit. I devoted my address mainly to an exposition of the religious aspect of Zionism, showed that it aimed at the fulfilment of all the aspirations enshrined in the Prayer Book, that it meant the realization and revivification of Judaism, and that to oppose Zionism was to thwart the very purpose for which the walls of the synagogue had re-echoed with supplications throughout the ages.

All these addresses formed but a prelude to the

1 Lesson from the Prophets. 
principal gathering in the King's Hall, at which the Governor, Sir Walter Davidson, ${ }^{1}$ presided. I had previously called upon him at his official residence, a substantial and magnificent mansion, richly and tastefully furnished, and surrounded by spacious lawns. Sir Walter took a pride in the pictures and other objets d'art of Government House, and accompanied the demonstration of each article with a little lecturegiving the names, dates and typical characteristics of each article-like a fluent museum-guide. He told me that he was a cousin of General Sir Louis Bols, the Chief Administrator of Palestine, who had been recalled to make room for Sir Herbert Samuel, but he was apparently unaware of the dissatisfaction with his cousin's regime, and I thought it inadvisable to touch upon the question lest his sympathies with the Zionist cause might be shaken. On arrival at the King $s$ Hall he was welcomed by the leading Zionists, as well as by Mr. George Judah Cohen, ${ }^{2}$ the octogenarian President of the Congregation, who was commonly regarded as the Rothschild of Australian Jewry, but who probably surpassed any of the Rothschilds in the punctuality with which he entered his office at nine o'clock every morning.

The proceedings began loyally with the National Anthem, and after a resolution of thanks to Great Britain for accepting the Palestine Mandate, which was moved by the Speaker, the Hon. Daniel Levy, and adopted unanimously, I delivered my speech. The hall was crowded with an intelligent and sympathetic audience, but I have seldom spoken under more disconcerting circumstances, as my speech was subjected to the constant interruptions of an over-zealous individual in the third row, who wished to mark his approval at the end of every few sentences by vociferous applause. After a few such outbursts he was approached by a steward and

1 Died September, r923.

2 Brother of the late Alderman Louis S. Cohen, formerly Lord Mayor of Liverpool. 
requested to moderate his ardour, but his acquiescence was but brief, for just as I had finished a description of the plight of the pogrom-stricken Jews in Eastern Europe, by which the audience was apparently moved, my irrepressible admirer loudly exclaimed "Hurrah!" and clapped his hands until they must have ached. He was a Jewish ex-soldier, whose nerves had suffered in the war, and it was thus thought unfitting to eject him from the hall, as would have been done had he not enjoyed such a patriotic record, although it was suspected that his conduct was due to a much more recent and less glorious cause than the war-in fact, to the injudicious manner in which he had quenched his last thirst. I was thus exposed throughout my speech to these tantalizing ebullitions of applause, which were made without the least regard to their propriety, and which amused some members of the audience as mich as they annoyed myself. I am afraid that these interruptions, by imparting relief to the earnestness of the occasion, produced a relaxing effect upon the generosity of my hearers, for the response fell short of my expectations. It began with $£$ rooo from Mr. George Judah Cohen, followed by a few donations of $£ 500$ each, whilst the list of givers of $£$ roo each included-to the agreeable surprise of most of those present-Rabbi Francis Cohen, who had evidently stepped down on the right side of the fence. The total subscribed that night was a little over $f 8000$, and as this was only a third of the amount raised in Melbourne I exhorted the audience to co-operate in making up the difference as early as possible.

Three more addresses followed that week-one to Jewish women upon women's work in the Holy Land, another to representatives of all Jewish societies, and the third to the Jewish Literary Society, at each of which further donations were given. At the last of these gatherings I was able to announce that the famous musician, Mr. Benno Moiseiwitsch, who was playing in Sydney at the time, and accompanied me to the meeting, had 



\section{$\cdot$}




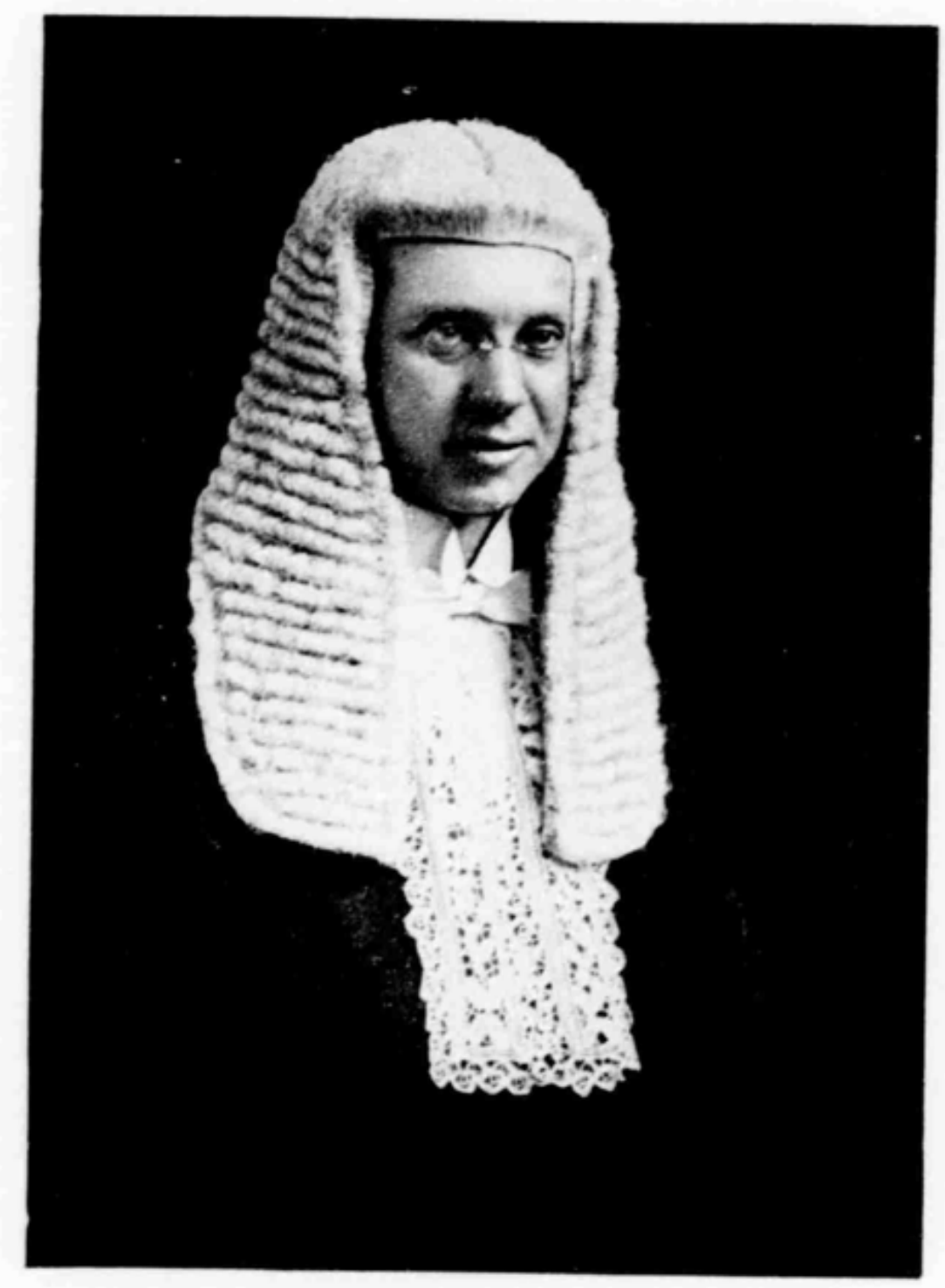

THE HON. DANIEL LEVY

SPEAKER OF NEW SOUTH WALES 1.EGISLATIVE ASSEMBLY

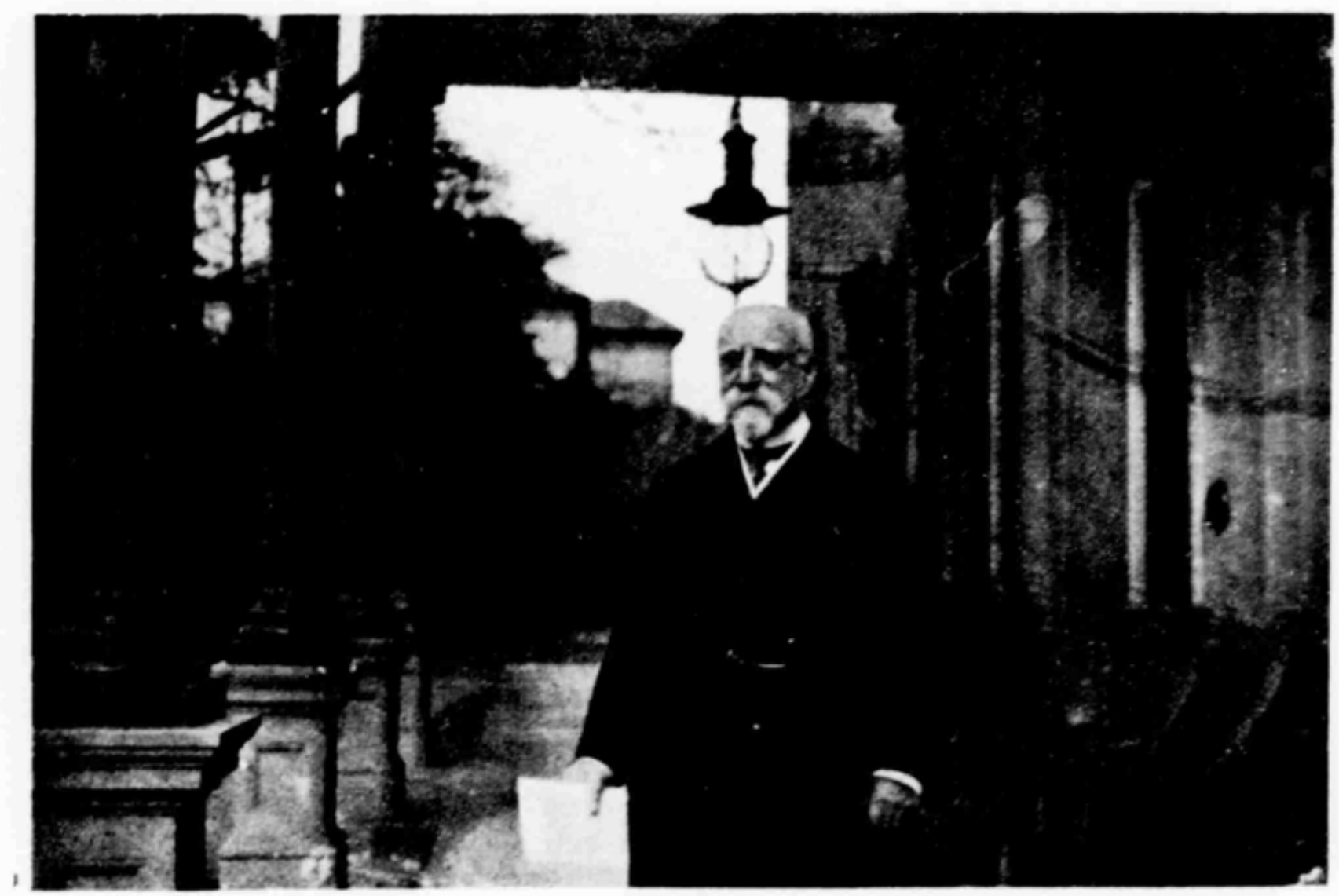

MR. GEORGE JUDAH COHEN, SYDNEY 
agreed to give $£$ rooo for the endowment of pianoforte scholarships in Palestine, to be awarded annually. He had formed this decision as the result of the conversations we had begun in Perth and continued in Sydney, and it was naturally received with considerable applause.

The days were laboriously spent in wheedling promises or cheques out of people who did not attend any of the meetings, or who attended without leaving any token of support. My principal guide and counsellor was the President of the Zionist Society, Mr. Solomon Pechter ; ${ }^{1}$ a native of Galicia, and a self-made man, whose passion for Palestine was the genuine thing, and who had already made arrangements to migrate thither with his family. Another valuable supporter was Mr. Percy J. Marks, one of the few Australian-born Jews with a true comprehension of the Zionist ideal. I always met with a patient hearing at these private calls, and found unfortunately that there was still a great deal of ignorance about the aims and implications of Zionism. There was a curious fear on the part of one or two people that the eventual development of a Jewish Commonwealth would involve the disfranchisement of the Jews in the Australian Commonwealth; and even when I exploded that bogy there was a lurking suspicion that to support Zionist aspirations materially was somehow incompatible with loyal British citizenship, despite the British administration of Palestine. But these objections were seldom upheld after discussion.

1 Died I921. 


\section{CHAPTER IX \\ AUCKLAND JEWRY}

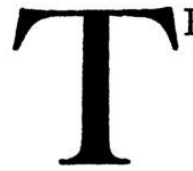

HE delusion of my childhood that it was only a half-day's trip from Australia to New Zealand, which clung to me subconsciously even when booking my passage from Sydney to Auckland, was finally dispelled after I. had been twentyfour hours on the great Pacific liner that was ultimately bound for Vancouver, and I realized that I should hear the monotonous plashing of the waves for another three days before we reached land. My voyage was from one beautiful harbour-the most beautiful in the world, so patriotic Australians, with no little justification, declare - to another beautiful harbour, though the port of Auckland, with all its romantic picturesqueness, cannot compare with the glorious panorama of Sydney's haven ; and as the sea fortunately belied its rude reputation in these parts I felt invigorated at the end of the journey. There are only 2000 Jews in the whole of the Dominions, scattered in small groups from north to south, and as the pulse of Jewish life was reported to beat there even more feebly than in Australia my expectations were but modestly attuned. Little did I dream that my visit to New Zealand was to prove the most successful chapter in the whole of my tour.

A friendly welcome awaited me on the wharf from a deputation headed by Mr. Alfred Nathan and his nephew, Mr. David Nathan, whose family had been settled in Auckland from the very day on which the British flag had been planted there. Jews had, indeed, played a notable part in the early development of the city and 


\section{AUCKLAND JEWRY}

provided its first two Mayors ${ }^{1}$ as well as later ones, whilst its first Jewish Mayor was afterwards Town Clerk for twenty-seven years. Our exchange of greetings was suddenly interrupted by the introduction of a Christian lady, who, I was told, had travelled a hundred miles to meet me. She was a matronly person, with rubicund cheeks, who beamed upon me with a deferential air as though I were the forerunner of the Messiah, though I rather suspect that she was disappointed at my not wearing a venerable beard.

"I'm so happy and proud to shake you by the hand," she said feelingly, and, tendering a couple of banknotes, she added: "and this is my little contribution." Her spontaneous act of sympathy, outshining in eagerness even the most ardent of local Zionists, evoked no little astonishment, and was designated an event of good augury. I was soon to learn that it faithfully reflected the attitude of a large section of the Christian world in New Zealand, who were following the fortunes of Israel in the Holy Land with profound interest, partly because the Dominion troops had played a valiant part in wresting the land from the Turkish yoke, but still more because so many among them believed that the British were the lost Ten Tribes.

But if the first token of support came unsolicited from a Christian well-wisher, it was soon forgotten in the rivalry of keen response from the Jewish community after I had made my formal appeal. There are only 500 Jews all told in Auckland, and even if all the adult members of the congregation had been present in the synagogue on the night of rain and storm on which I addressed them, the little shrine would not have been crowded; but the scene of excitement and infectious enthusiasm that began after my discourse could scarce have been greater had there been a full muster. The impetus was given by the Nathans, who, in accordance with the reputation of their family as pioneers, led the

\section{P. A. Phillips and Henry İsaacs.}




\section{THE JOURNAL OF A JEWISH TRAVELLER}

way with exemplary generosity. They had intended, before my arrival, to give a donation of $£$ roo on behalf of their firm; but after I had spoken, they revised their decision and promised a personal contribution of $£$ I000 each. The announcement was greeted with long and deafening applause, despite the holiness of the precincts, and the rafters soon rang again when I called out that there was a third donation of $£$ I000 from the firm of Messrs. Lichtenstein, Arnoldson and Paykel. Other large gifts followed, though in a slowly diminishing scale, and for fully an hour I was kept busy announcing them whilst the secretary eagerly wrote down the pregnant figures. The fruits of the meeting amounted to over $£ 6000$, and the local press, which published a glowing report the following day, described the occasion as "the most enthusiastic meeting held in the eighty years' history of the Jewish community of Auckland." The next two days were busily spent in calling upon those who had been unable to attend the synagogue gathering. They were days of strenuous labour and gratifying experience, for they brought up the record to over £8000.

The interest displayed by the non-Jewish community found expression in two public functions. The first was a civic reception given in the handsome Town Hall, whose erection, like many other municipal improvements, was carried out during the four-year mayoralty of $\mathrm{Mr}$. Arthur Myers. ${ }^{1}$ A welcome was accorded to me in the Council Chamber by the popular Mayor, Mr. J. H. Gunson, whose address showed that he was not content to utter ceremonial platitudes, but had taken the trouble to inform himself in detail about the projects and prospects of the Zionist movement; and during my reply I noticed among the audience a former fellow-prisoner of the Ruhleben Internment Camp, the musician, Mr. Horace Hunt, who was apparently as much surprised at the coincidence as myself. After the reception I was

1 Now Sir Arthur Myers. 
entertained to luncheon at the Northern Club, of which I was elected an honorary member. The Mayor, near whom I sat, discussed the practical aspects of the resettlement of Palestine and was anxious to know something about the economic occupations in which Jews engaged. When I told him that they were now represented in almost every trade and industry, even in mining, he replied : "Oh, yes, I know they are connected with mines, in South Africa, for example."

"I don't mean that," I at once replied. "I mean as actual miners, underground labourers."

"And where is that ?" he inquired.

"At Boryslav, in Galicia, where they work in the coal mines and have gained a reputation for pluck and perseverance."

"That interests me very much," said Mr. Gunson. "I wonder whether we could get a few hundred of them to come out here. We have a great deal of trouble with our local miners, who are often on strike."

I could not recommend the importation of Jews from a distance of 12,000 miles as potential strike-breakers, and besides, I urged, the cost of their transport was too big a sum for themselves to provide, whilst the New Zealand Government, which was expelling industrious Germans, would certainly not pay thousands of pounds to introduce Polish Jews.

The second function was a public meeting at the King's Theatre, at which the Mayor presided over a large assembly, consisting mostly of Gentiles. Upon the conclusion of my address, an inspiriting speech was delivered by Colonel C. E. R. Mackesy, C.M.G., D.S.O., a staunch believer in the British-Israel idea, who was the first New Zealand soldier, in Lord Allenby's campaign of liberation, to set foot on Palestinian soil. In vivid style he narrated the course of the operations that led to the entry of the British into Palestine, and fired his audience with enthusiasm by predicting a glorious future for the wonderful land. 
I spent only three days in Auckland, but every day was crowded with events, and every hour utilized to the full-interviews with reluctant donors alternating with calls upon Rabbi Goldstein, who had ministered to the community for nearly forty years and who was overtaken by untimely sickness on the eve of my arrival; and the lectures and addresses relieved by an "At Home" given by Mrs. David Nathan, who combined a charming personality with creative enthusiasm. Her interest in the Plunket nursing system, which flourishes throughout the young Dominion, suggested to her the advisability of its application to the rejuvenation of Palestine. She asked me whether the idea would be practicable, and whether the Jewish women in New Zealand might be encouraged to raise special means for the purpose. I eagerly welcomed the proposal and urged that systematic steps should be taken for its realization. Mrs. Nathan devoted herself to the scheme with tireless energy, and thanks to the generous support that she was able to enlist, two London nurses trained in the Plunket methods are already engaged in useful work in Palestine, soon to be followed by others.

It was at the house of Mrs. Nathan that I met Mr. Maurice Keesing, whose two volumes of Dramas and Poems, marked by facile composition, fertile imagination and sprightly wit, show that the literary genius of the Jew can flourish at the Antipodes as well as in any other part of the world. Many of his poems are inspired by local scenery, and a striking fantasy is woven round the picturesque Maori settlement of Rotorua. His dramas are rather for the study than for the stage, and one of them is dedicated to Lord Islington, a former Governor of New Zealand, who has apparently not been restrained, however, by this Jewish tribute from opposing the creation of a Jewish National Home. 



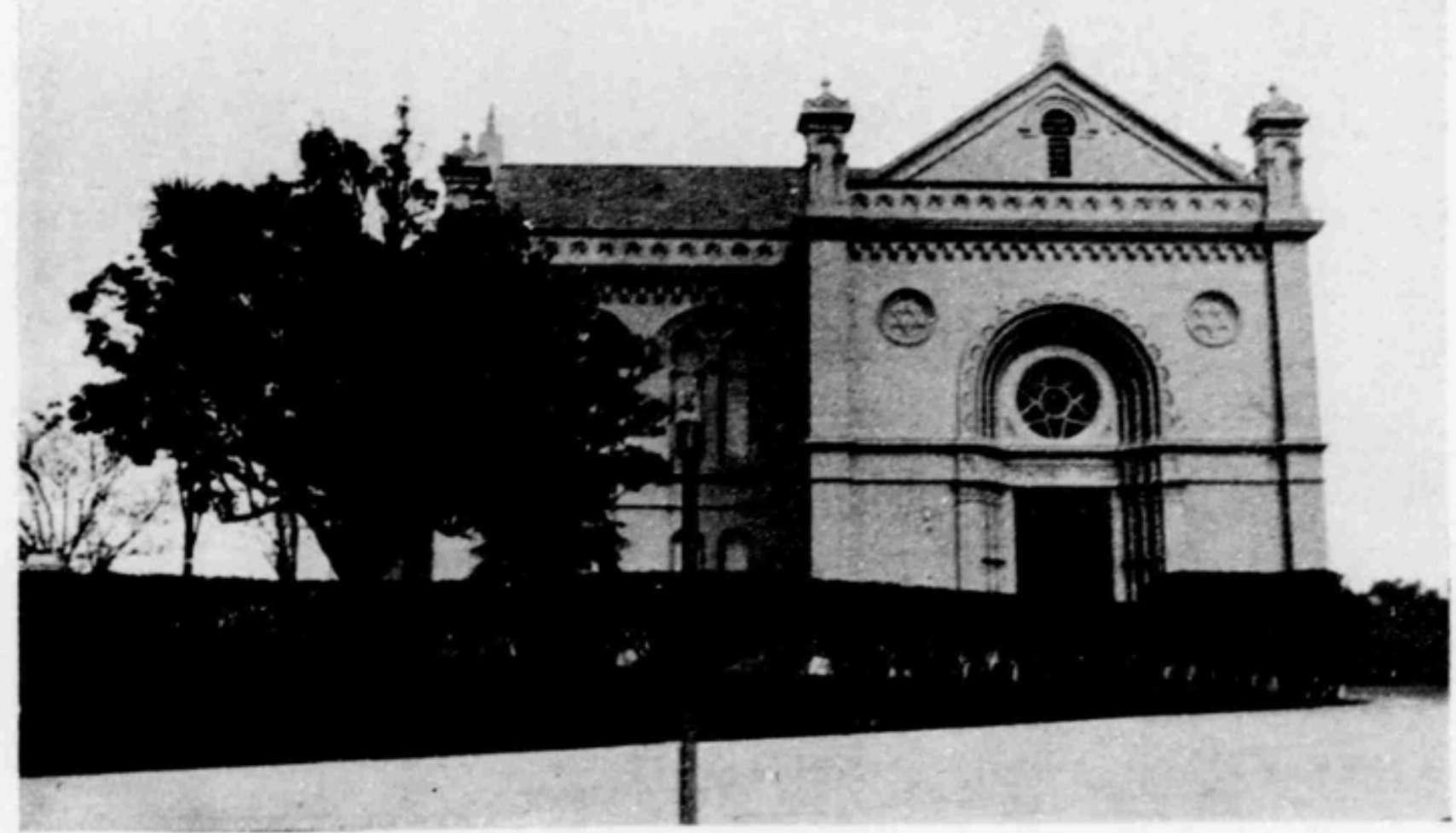

SYNAGOGUE AT AUCKLAND

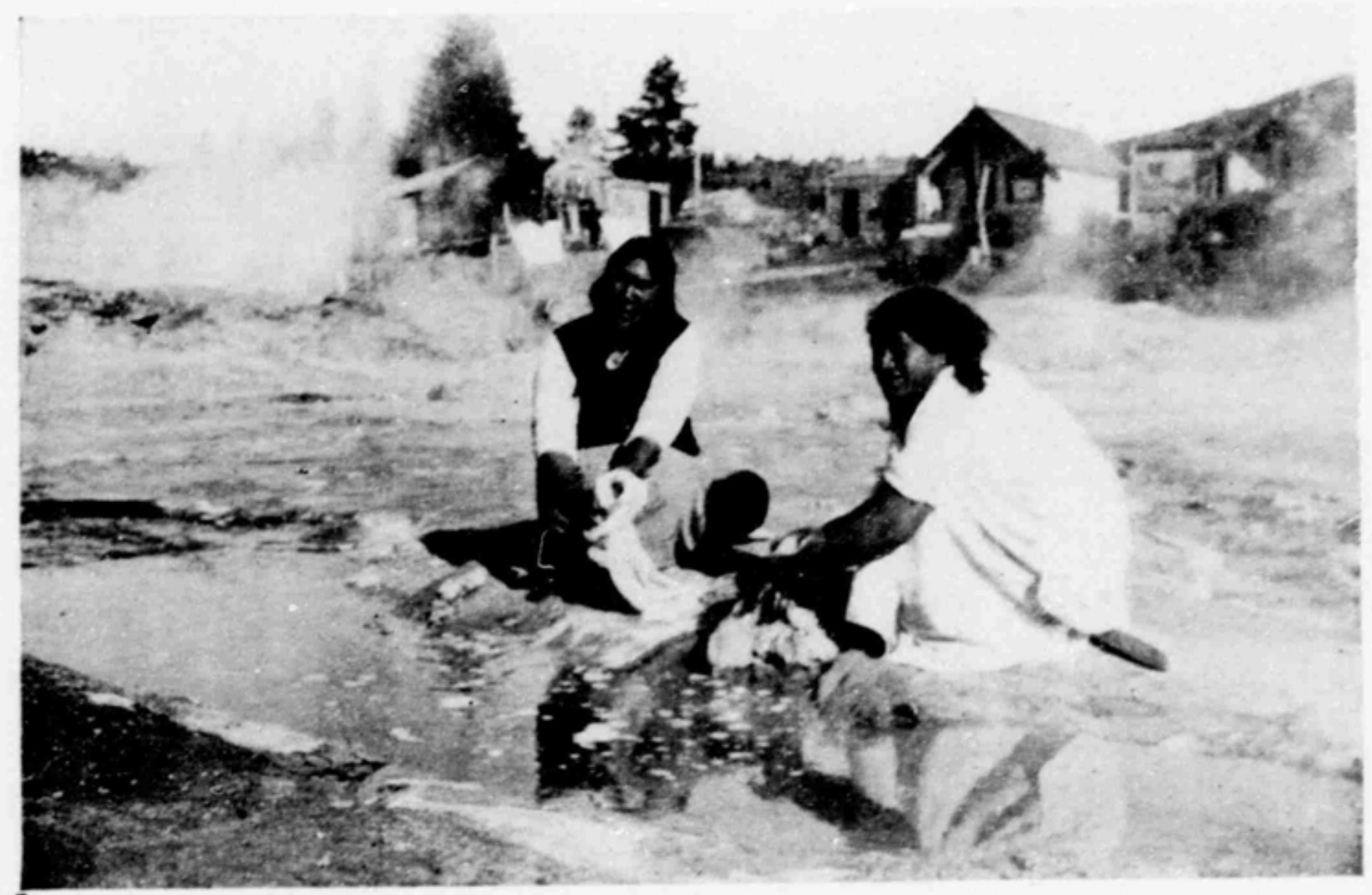

MAORI WOMEN WASHING IN HOT SPRINGS 


\section{CHAPTER $\mathrm{X}$}

\section{AMONG THE MAORIS}

\section{SOUTHWARD journey of seven hours by}

rail from Auckland brings you to a region unparalleled for its array of weird wonders.

- It is a region of geysers and thermal springs, of boiling fountains and bubbling pools, of menacing craters and hot fissured soil, set amidst placid lakes and frowning mountains. It is the region where once existed the eighth wonder of the world, the Pink and White Terraces of Rotomahana, those beautiful, spacious and symmetrical alabaster formations that drew throngs of admirers from all parts of the world. The Terraces were engulfed by the volcanic eruption of the neighbouring Mount Tarawera in June, I886, and now lie buried beneath the waters of the Lake Rotomahana. You can still sail on the Lake in a launch and hear stories of the awful cataclysm that was accompanied by thunder and lightning, by the belching forth of mud and ashes from the angry crater, and the cracking and quaking of the earth; you can hear tales of how some of the $I_{53}$ victims who were buried alive met their death bravely; you can approach fairly near to the foot of the mountain, from which rise white clouds of steam, and dip your hand into the hot waves. Yet though you gaze ever so piercingly through the unusually smooth surface, you fail to see even a trace of those Pink and White Terraces, which, in their natural splendour, once vied in fame even with such imposing creations of mankind as the sombre Pyramids and the majestic Taj Mahal.

But though the Terraces are gone, the region to which they brought renown is still richly endowed enough with 


\section{THE JOURNAL OF A JEWISH TRAVELLER}

attractions to draw visitors from the other end of the globe. For its hot geysers and springs are repeatedly in action; it is the home of thousands of Maoris who still cling to many of the customs and superstitions of their forefathers ; and it boasts of the modern town of Rotorua, which has been laid out by the Government as a pleasant health-resort, with all manner of hot baths for the cure of rheumatic ailments and skin diseases. The most interesting Maori village is Whakarewarewa, which is conveniently shortened to Whaka. It is only two miles away from Rotorua, and coaches ply frequently during the day between town and village.

Whaka presents a strange and eerie scene, probably without equal throughout the world. There are clusters of wooden huts built on the sandy or stony soil, in which the natives live, clad in modern garb, and all around are geysers and hot springs from which snow-white clouds of vapour arise or jets of boiling water shoot aloft, whilst the air reeks of sulphur. Every geyser has its own particular characteristics and significant name, Pohutu, " the splasher," and the Prince of Wales' Feather, being two of the most popular, if, indeed, such perilous outbursts of nature can be said to enjoy popularity. Pohutu plays only at intervals, occasionally requiring a little soap to coax it, and a Maori keeper blows a shrill whistle some time beforehand, so that visitors in the town can hurriedly betake themselves to the scene. There they are greeted by an impressive spectacle: a huge jet of roaring, boiling water shooting upwards for a hundred feet, for about fifteen minutes, and scattering spray for hundreds of yards around, which compels all observers to keep at a discreet distance. But the playing of the geysers is perhaps less remarkable than the quaint antics of the hot mud-pools, which are of varied size and shape. One of these continually forms jumping-frogs that disappear, whilst another incessantly creates models of lilies, which are no sooner fashioned than they melt away.

You need the help of a native to guide you through 
this weird romantic region, not alone to explain the fantastic phenomena of nature, but also to prevent you from taking a path that may lead to some hidden crater or innocent-looking pool. The two most famous guides are the twin sisters, Georgina and Eileen, who are exactly alike, not only in their features and their raven locks, but also in the tattoo-marks that disfigure their mouth and chin. They speak English, as indeed do all educated Maoris, with a freedom from accent and a surprising elegance. The guide who conducted me, Bella, was free from tattoo-marks, and might have been taken for an Englishwoman with a strain of Southern blood. Her hut was like a museum of Antipodean curiosities and Occidental souvenirs, for side by side with grotesque wooden carvings and the "piupiu" or dancing-skirt of flaxen reeds, it contained photographs and gifts of various kinds from Englishmen and Americans, whom she had conducted over her native heath. The entrance to her habitation was adorned by some forbidding figures carved in rata wood, who, I understood, represented some of her ancestors. She explained some of the symbolism that underlies the grim barbaric designs in Maori art, such as the outstretched tongue of defiance that marks the warrior, but hinted at more than she elucidated, parrying the curiosity of the stranger with a graceful shyness. She led me through this Maori domain with an air of pride, showing me how her people cooked their food over the hot springs and washed their clothes in the hot pools, in which, at night or at dawn, they also bathed. She pointed to a well-like cavity in the ground, surrounded by rocky stone, and told me it was called the "Brainpot," because in it were cooked the brains of an old chief, Te Tukutuku, who had hidden in a cave for two years from his enemies and then was captured and beheaded ; and when I asked whether such practices were still continued she replied emphatically : " Certainly not, that was a very long time ago. Now we are all educated." 


\section{THE JOURNAL OF A JEWISH TRAVELLER}

"And aren't you afraid to go on living here ?" I asked. "There may be another eruption some day."

"Let it come!" she replied firmly. "This is our home. Here we live, and here we shall die."

It is education that has caused the change in the ways and customs of the Maoris, for there are over I30 schools-primary and secondary-in New Zealand for their instruction. They number fewer than 50,000 and form less than a twentieth of the entire population of the Dominion. They have their own councils for defined districts, and their own land boards for the administration of native lands, whilst they elect representatives of their own to the Wellington Parliament. Intercourse with the English has led to an increase of half-castes, who, at the last census in I9I6, numbered nearly 7000, half of whom lived as members of Maori tribes and the other half as and among Europeans. There is thus a gradual extinction of the living forms of the old Maori civilization, which are practically confined to the dances and " hakas" that are arranged for special occasions, as on the visit of the Prince of Wales, and to the greeting by the rubbing of noses that you can see any day in the street. The dances are of the group category, rhythmic in style, and symbolic in nature, which are now performed to pianoforte accompaniment.

One evening I saw a dancing display in a hall in Rotorua, in which about a dozen girls and women took part, but in which only two men could be induced by the local impresario to join. It was a rather bleak hall, opened only one night in the week, and the impresario who explained from the platform the character of each event on the programme then descended to the wheezy piano, on which he tinkled to the performance. The dancers wore over a bright red skirt the flaxen " piu-piu," which rustled to their movements. The most effective dances were done with the accompaniment of the "poi," a couple of small white cloth balls attached to string, which were swung in various rhythmic combinations and 
permutations; and the most novel was a canoe dance enlivened by song. The " haka" is more like a warwhoop than a dance, executed with outstretched tongue, brandished fists, stamping feet and savage yells. Little Maori children will run after you, calling "A penny for a haka!" and at once line up with lolling tongues to go through the ugly exhibition.

Rotorua attracts visitors from far and near, who seek healing in its sulphur baths and mud baths, and in the waters of its strangely named springs, "Rachel," "Priest" and "Postmaster." It has also attracted settlers from different lands, from China and India, from France and Russia, who have opened shops in the growing town. But its strangest denizen seemed to me a little Polish Jew, whom I found in possession of a drapery store, wearing on his watch-chain the Maori "tiki" or greenstone charm. He lacked the typical appearance of the Polish Jew, for he had left his home in youth, but his dark eyes shone with the unquenchable fire of his race.

"I ran away from my home in Warsaw thirty years ago," he said. " I was seized with the longing for Palestine, and I went against my father's will. I lived and laboured in Rishon-le-Zion for two years, but the work was hard and my strength gave out. So I sailed to Australia, then to New Zealand, and here I am."

"And won't you go back to Palestine now ?" I asked.

"Too late," he said, with a shake of the head. "I am too old-and I am a theosophist now." And he set off on a rambling disquisition, trying to vindicate his peculiar mental evolution. "But tell me, how are my brethren in Rishon-le-Zion ?" he asked eagerly. And as I spoke to him of the new life that was dawning in Judea under a Jewish Governor his eyes wandered wistfully from the geysers of Rotorua to the orange-groves and vineyards of Zion. 


\section{CHAPTER XI}

\section{WINDY WELLINGTON}

T HAD not been in the capital of New Zealand many moments before I realized the truthfulness of its description as "windy Wellington." 1 Strong breezes blow steadily from the sea, sweeping through every street and round every corner, making it unnecessary for the policeman ever to ask any pedestrian to move on. But despite the gales that often rage in and around the city, and despite the fact, too, that it is situated in the very heart of a volcanic region, it has attracted the largest population in the Dominion and, as a corollary, the largest Jewish community. The superiority of Wellington Jewry in numbers, however, is slight, as it comprises only some 700 souls, whilst in general character and social structure there is but little difference between it and the Auckland community. The majority, as in the northern city, consists of Russian or other East European Jews, who have mostly passed through a preliminary process of anglicization by a few months' or few years' sojourn in England, and whose children, born beneath the invigorating sky of the Antipodes, have most of the sturdy physical characteristics of their neighbours. They nearly all enjoy a comfortable livelihood, and many were the stories of romantic progress that I heard about those who had landed with a foreign accent and with the proverbial half-crown in their pocket, and who now own multiple shops and at least one motor-car. There are also a goodly number of Jews whose families have been living in the country over half a century, and who take a conspicuous part in the commercial life of the Dominion. 
At the head of the community there is also a Nathan family, although it has no connection with the family of similar patronymic in Auckland. Its founder, the late Joseph Nathan, was the promoter of the Manawatu railway and had served as President of the Chamber of Commerce ; but whilst he would probably have remained unknown to the greater world beyond if he had contented himself merely with these local achievements, he acquired international fame as the inventor of "Glaxo," which " builds bonnie babies." The sons of Joseph Nathan have developed their patrimony to proportions far transcending the paternal vision, and are graced withal by a generous public spirit. It was to them, therefore, that I naturally turned to head the local list and set an example to the community; nor was my appeal in vain, for they readily promised $f$ rooo. There are other Nathan families there too, occupying a less conspicuous and perhaps less wealthy position, and it was no small tax upon the memory to distinguish between them and all their numerous branches.

I was installed in the Midland Hotel, where the manager's Lancashire accent awoke a responsive chord, and where the spirit of democracy reigned so triumphantly that the word " sir" was unknown and I was addressed by name by everybody, from reception clerk down to the boots. Soon after I was called upon by the local pressmen, who told me that my mission had aroused general interest, for Wellington did not receive too. many public speakers from the mother country, and the city tramcars had been covered for the past fortnight with attractive posters advertising the Zionist Demonstration that was to take place with the support of the Prime Minister and the Acting Governor-General at the Town Hall. The representative of the Wellington Evening Post began his interview, strangely enough, by inquiring whether I had been a pupil at the Manchester Grammar School, and upon my replying that I had been, and that it was nearly a quarter of a century since I had left, he 


\section{THE JOURNAL OF A JEWISH TRAVELLER}

astonished me by telling me that he had been a contemporary of mine and had tied with me for a history prize. I confessed that I had meanwhile forgotten that particular episode in modern history, but I soon recollected the name of my juvenile rival, and we both reflected on the strange workings of Providence that had brought us together again, after so prolonged an interval, 13,000 miles away from the scene of our divided success. Needless to say, my old school-fellow rendered me a generous service by reporting me extensively in his paper and by securing for me the sympathetic interest of his colleagues.

The Town Hall meeting was preceded by two addresses to Jewish audiences. The first was delivered at an evening gathering in the home of the President of the Congregation, Mr. M. Myers, a prominent solicitor, from whose window I had a wonderful view of Wellington Harbour at night, iridescent with a thousand twinkling lights. It was a fruitful function, for several three-figure donations were promised, though many of the guests wished to take counsel of their pillow and announce their gifts a day or two later. Among those whom I met was the Hon. Mark Cohen, a veteran journalist, who had been connected with the Otago Times for fifty years, rising from junior reporter to editor, and who had recently been elected a member of the Upper House of the Dominion Parliament. In appearance he was a perfect exemplification of the law of racial assimilation, for his tall distinguished figure did not bear the least resemblance to the children of the Ghetto. Another Jewish member of the Upper House whom I met was the Hon. Charles Louisson, a courtly old gentleman, who had acted for four years as Mayor of Christchurch. ${ }^{1}$

The following afternoon-it was a Sunday-I addressed a larger Jewish audience in a masonic hall. Unfortunately the elements were against me, for it was winter, and the gathering was not as numerous as I had expected; but my appeal fell upon sympathetic ears and the response

1 Died 1924. 
was satisfactory - a total being reached of $£ 5000$. But the attitude of the Rabbi was disappointing. Instead of supporting me on the platform, as his position required, he sat, with cool calculation, at the back of the hall, whence, as soon as donations were invited, he discreetly withdrew on the pretext of going to arrange an appointment for me with a potential donor, his exit being followed by a chorus of sarcastic comment. But at the great demonstration that was held the same evening in the Town Hall, where it was known that there was to be no appeal for funds, the pastor bravely occupied a seat in the front row of the platform, beside the most distinguished citizens of the capital.

The demonstration was remarkable in more than one respect. It was the largest gathering that I addressed in the whole of my tour, numbering close upon 3000 people, and testifying to the keen interest of the New Zealanders in the fate of the Holy Land. The assembly might have been even greater still, had it not been for the time chosen, for in one of the local papers there was a reproachful advertisement, headed "Maranatha," complaining that the meeting had been fixed for a Sunday evening, and essaying to prove, with a sprinkling of Biblical texts, that the return of Israel to his ancient land would be followed by the second Advent. The meeting, over which the Mayor presided, was perhaps most noteworthy for the conspicuous part played by the Acting Governor-General (Sir Robert Stout) and the Prime Minister, the Right Hon. W. F. Massey. I had called upon both of these gentlemen, soon after my arrival in the city, with a letter of introduction from Lord Milner (then Colonial Secretary), and thanked them for the very valuable support they had so readily promised.

Sir Robert Stout, a sage and venerable figure, who has held the office of Chief Justice for nearly a quarter of a century, paid a tribute to the idealism of the Jewish people, but doubted whether they would leave a land possessing so many advantages as New Zealand. Mr. 
Massey, speaking in a similar eulogistic strain, extolled the merits of two Jewish Prime Ministers-of Benjamin Disraeli, who had made the Queen of England the Empress of India, and of Sir Julius Vogel, " one of the most far-seeing" of New Zealand's Premiers-and declared that the British nation had benefited by its justice to the Jew. Then, quoting copiously from the prophecies of Ezekiel, he expressed his conviction that recent events in Palestine were a clear fulfilment of the promises of Scripture, and as this solemn utterance came rolling from the lips of the burly statesman a burst of tremendous applause resounded throughout the hall. The prophetic aspect of Zionism was further emphasized by a prominent member of Parliament, Mr. R. A. Wright, who, in a vote of thanks for my address, said that " having personally witnessed the fulfilment of so much of what he had learned from the Prophets, he was prepared to say that in future the Israelitish people would rule over the whole of the territory that had once been subject to King Solomon. That was a much greater territory than the land of Palestine."

But unfortunately the glowing visions of these Christians in New Zealand have been ruthlessly dispelled by the enemies of Israel in other lands. 


\section{CHAPTER XII}

\section{IN SOUTH ISLAND}

\section{$\mathrm{S}$ in North Island so also in South Island there are only two organized Jewish communities, but their combined numbers are equal to only one-half of the Wellington congregation,}

Christchurch having about Ioo and Dunedin about 250 Jewish souls. In these remote and sparse communities, Judaism naturally has a struggle for existence, and the marvel is that it survives at all. There are difficulties of conformity with traditional rites, and the exposure of the little Jewish isles in the surrounding Gentile ocean naturally results in gradual corrosionsons of Israel taking unto themselves Christian wives, and daughters Christian husbands, to the distress of parents and the despair of the community. But mixed marriages are probably not more frequent in South than in North Island, or in some of the smaller Jewish centres in Australia, though they form a more conspicuous feature of social life than in European Jewry. Most of the Rabbis are opposed to the making of proselytes for the purpose of marriage, for fear lest that would but encourage such mixed unions, but there was a complaisant minister in Tasmania, I was told, to whom those who were bent upon having a Christian consort welcomed into the parent faith never appealed in vain. The social perils that beset Jewish life in New Zealand have doubtless their counterpart in the Fiji Islands too, where a small community, recruited mostly from the Dominion, has been established in Suva, and one of its members, the Hon. Henry Marks, has attained

G 
the distinction of being elected upon the Legislative Council.

It was probably due in no small measure to the limited opportunity for public activity afforded by congregational affairs that so many Jews have devoted their talents to political life, in which they have achieved conspicuous success. By far the most distinguished is Sir Julius Vogel, who was Prime Minister from 1873 to 1875 , and again for six months in 1876 , and who was later Postmaster-General and Colonial Treasurer (I884I887). It was he who established the immigration and public works system of New Zealand, initiated the mail service to San Francisco, organized the system of colonial defence, and created the Government Life Assurance and Public Trust Office. $\mathrm{He}$ also started the cable service between New Zealand and Australia, and founded the first daily paper in New Zealand, the Otago Daily Times, of which he was the first editor. The Jews of North Island have also produced a Cabinet Minister, namely, the Hon. Arthur M. Myers, ${ }^{1}$ who, in the Mackenzie Ministry, held the portfolio of finance, railways and defence, and in the National Cabinet, during the war, was Minister of Munitions and Supplies and Acting Minister of Finance.

Thanks to the achievements of these and other Jews in New Zealand, the name of the Jew is held in high esteem in the Dominion and an intelligent interest is taken in Jewish aspirations. In no other part of the world did my mission receive such extensive and friendly notice in the press, or was it made the theme of long and laudatory leading articles, written not only with sympathy but with knowledge. In Christchurch, where, owing to the brevity of my stay, I was unable to address any meeting except a private one of the congregation, I was interviewed by both local papers, one of which, The Press, published a heartening leader. When I was in Palestine six months later I met a Lyttelton clergyman in a Tiberias

1 Now Sir Arthur Myers. 
hotel, who, on hearing that I had spoken in New Zealand, at once knew my name and told me there had been disappointment in Christchurch because I had not given any public address. For my part, I was sorry that I had so soon to leave that city, which, with its cloistral square and sedate thoroughfares, reminiscent of a cathedral city in England, and with rich green meadows on its borders, left an impression of ineffable charm.

It was with a sense of relief that I reached Dunedin, for it marked the southernmost terminus of my wanderings, though had there been any inhabited regions with a Jewish community still nearer to the South Pole, I should not have hesitated to set out upon their quest. Dunedin has preserved not only in its name but also in the accent of its citizens and their religious sectarianism the origin of its Scottish founders, and it was in the Burns Hall-sacred to the memory of the national poetthat $I$ addressed a large and enthusiastic meeting on the cause of Zion. The Mayor presided, and there was a crowded platform of the leading notabilities of the citylay, clerical and Salvation Army. In moving a vote of thanks to me for my address Sir George Fenwick, proprietor of the Otago Daily Times and chairman of the New Zealand branch of the Empire Press Union, said, in reference to the Palestine Mandate, that "Great Britain, in voluntarily accepting this great task, had done no more than she ought to have done, and was going to add one more to the great triumphs she had accomplished in the world," and the Rev. Dr. Andrew Cameron, Chancellor of the Otago University, in seconding, said that " he believed the Zionist movement would prove a great blessing to the whole world."

After the meeting had closed, as it had opened, with the National Anthem, I was approached by a gentleman who introduced himself as the brother of Mr. Lucien Wolf. He was, however, not known locally as a Jew himself, and had indeed been organist for many years of a leading church ; but his awakened racial consciousness prompted 
him to offer a contribution, of which his London brother, a notorious anti-Zionist, would have strongly disapproved. Of such are the paradoxes of Jewish life.

The following day Mr. David Phillips, the Treasurer of the Congregation, conducted me on a round of visits for the purpose of obtaining pledges of support. He had already received by the first post that morning a cheque for $£$ roo from a gentleman who was no longer associated with the community, but who had heard my speech the previous evening and sent a letter laying bare his soul ; and as I had previously obtained a donation of $£$ I000 from Mr. E. I. Halsted, whom I had met in Wellington, and one of $£ 500$ from Mr. D. Theomin, whom I had seen in Melbourne, we had an excellent start. For the most part we found a ready and sympathetic response, though occasionally a little coaxing was necessary; but there was one man who, though very wealthy and most effusive in his expression of sympathy and of good wishes, stubbornly declined to contribute a single penny. I asked him to explain his objection, so that I might discuss it and try to overcome it. But with a melancholy smile he answered : "I have no objection. I wish you all success. But I won't give you anything." Hitherto those who had refused to give had at least offered some reason or excuse-lack of sympathy, of faith, or of means ; but this was the first time that I received a refusal from a man who protested his sympathy and yet could not deny. his wealth. It was an inscrutable case, which was scarce illumined by the information that I later gleaned that he had suffered-personally, though not financially-in the war. But apart from this singular instance the community acquitted itself most generously, so that at the meeting held in the synagogue vestry, at which I had the vigorous support of Mr. Saul Solomon, K.C., one of the leading lawyers in the Dominion, who contributed $£ 500$, I was able to announce a gratifying total exceeding $£ 3000$. I slept soundly upon it, and early the following morning began my return journey northward. 


\section{CHAPTER XIII}

\section{EXCURSIONS AND ALARUMS}

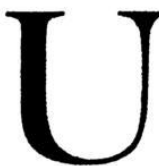

PON arriving in Wellington once again I found that I had a few days to wait for the next boat to take me back to Sydney, so resolved to utilize the interval to the best advantage. I spoke in the Jewish Social Club, where a musical programme was arranged in my honour; and I paid many a visit to passive sympathizers for the purpose of converting them into active supporters. One gentleman refused to contribute because he was reserving all his spare funds for the Club ; and another, because some fellow-members had cast reflections upon his child, the offspring of his Christian wife who had been refused admittance to the Jewish fold.

Interesting and stimulating, though not always agreeable, as I found these various calls, none was so exciting as the visit that I paid to a Jewish family at Masterton, or rather as the experience that I underwent on the way. Masterton is a small town situated some sixtyeight miles north of Wellington, and as the day fixed for the journey was a Sunday, when trains were also allowed to rest, I had to engage a motor-car. It was necessary to start very early, as the New Year began on the evening of that day, and I wished to be back again in Wellington in time for the synagogue service. It was therefore arranged that the car should fetch me from my hotel at seven o'clock, but it was a quarter-past eight before it arrived. The delay was caused by the discovery at the last moment that three of the tyres had been punctured by a discharged chauffeur, and by 
the laborious task of replacing them. It was an ominous beginning, but as the car had been thoroughly overhauled I felt reassured. I was accompanied by Mr. S. Gordon, a nephew of the late David Wolffsohn, the Zionist leader.

I was told that the road was rather rough, but had I realized all that was contained in that little word I should never have undertaken the journey. It was a cold,wet and windy morning. Half an hour after we had started the road began to rise slowly higher and higher, and then tapered away into the narrow ledge of a mountain, which rose sheer on our right, whilst on our left was a vast yawning abyss. Had there been a secure hedge or embankment on our left there would have been no risk, but the precipice along which the car was careering at twenty-five miles an hour was so narrow and irregular that the least swerve foreboded a danger too terrible to imagine. To add to the risk, there were frequent and sudden bends in the road, so that we could not see whether a car was coming from the opposite direction, nor did it seem possible for one to pass without a dreadful collision. "This is the famous Rimutaka Gorge," remarked my companion. The road steadily ascended until we were I760 feet above the level of the sea, and a vain regret seized me that I had ever come, for I thought we should never reach our destination. On our left were heavy clouds hovering over the black abyss, on our right were grim rocks sundered here and there by gaps through which the howling wind blew with such tempestuous fury that I thought we should be lifted off the ground and hurled below. We passed two cars on the way, and each time I thought there would be a crash and closed my eyes in dread anticipation. In one of them was a local celebrity of eighty-five going to church, and I felt a little self-reproach. But I could scarce summon enough courage to glance below the tops of the clouds or to take aught but a fleeting glimpse of the other side of the gigantic gorge, as my brain grew dizzy. At last, after 


\section{EXCURSIONS AND ALARUMS}

a sickening ordeal of an hour and a half, jolted, nerveshattered and exhausted, we reached the broad firm bosom of the earth once more. I thanked Providence that we had come through it alive, and our driver, a big, brawny man, bathed in perspiration, made straight for the first inn to fortify his shaken spirits.

Shortly before eleven o'clock, in record time, we reached our goal, and I firmly resolved not to return by that same way. The driver sought to reassure me: he had travelled along that road at all hours of the day and even of the night, and at all times of the year for the last twelve years, and he knew every bend, every dip and every rut from beginning to end. But I told him that I should not go back with him even if he made me a present of his car, and was determined to stay at Masterton until I could return by train.

Fortunately the people whom I had come to see made me most welcome, and asked me to remain with them until after New Year. Their name was Castleberg, truly a most fitting cognomen for the mountainous district in which they had built their home. Mr. Castleberg Senior was a hoary man of eighty, who had been a pioneer in the development of the town, and who had for many years driven a team of pack-horses with merchandise along the perilous causeway to Wellington and back until the railway connecting the capital with the growing town was completed. He had founded a prosperous co-operative association, owned many farms and horses and had served as Mayor of the borough. ${ }^{1}$ His wife, a refined and cultured woman, was a sister of the poet, Mr. Maurice Kessing, whom I had met in Auckland, and as, some months previously, she had sent her New Zealand War Bonds of the value of $£ 300$ to London as an offering to the Palestine Restoration Fund I knew that I was on friendly ground. They lived in a fine large house, built mostly of timber, as so many houses in New Zealand are, and. surrounded by a spacious and well-

1 Died r923. 
stocked garden, from which there was ready access to the homes of three married sons. There was little need to explain the object of my visit to the family gathering, for they had read my speeches and interviews in the papers, but they were pleased to handle the letters of introduction from the distinguished personages in England and Palestine that I always carried with me; and after a private council they told me that they would contribute $£ 750$, thus making up the Castleberg quota to a thousand guineas.

After lunch my travelling companion, Mr. Gordon, returned home by the same risky route, and I remained to celebrate the New Year with the Castlebergs. The sons with their wives brought presents in the evening to their parents, whose festive board they joined, and the ritual candles illumined the scene with their radiant beams. Here were thus assembled the whole Jewish population of Masterton, with the exception of a gentleman farmer and his wife who had passed me that morning on their way to Wellington. The evening sped pleasantly in the exchange of story and anecdote, and soon after I retired to rest I felt once more the jolting motion of the careering car and dreamed of hair-breadth escapes on the crags of the New Zealand Alps.

When the festival was over I returned by train to the capital, and as the engine slowly clambered the rack-andpinion railroad I was able to survey at ease the dreadful depths of the Rimutaka Gorge, which has no equal for awe and grandeur throughout the Antipodes.

My departure for Sydney was unfortunately delayed by a curious dispute that broke out among some of the crew of the vessel on which I had secured a berth. The firemen had taken violent objection to the cook and would not sail with him on board, whilst the stewards would not sail without him. The problem how to satisfy both parties engaged the subtlest minds among the would-be travellers who thronged the lounge of the Midland Hotel, and the Solomonic solution appeared to 
be that the cook should sail as a private passenger. In my enforced detention I paid a visit one afternoon to the Dominion Parliament and was lucky enough to hear the Prime Minister, Mr. Massey, deliver an important speech upon agriculture. I observed that the members were rather better behaved than the legislators in Melbourne and Sydney, and also that they had much more convenient accommodation, for they were each provided with a desk and writing accessories as well as with shelves for reference books. But the general plan and the forms and courtesies of procedure were very much like those at Westminster.

The shipping dispute, which was only one of many occurring at that time in that region, dragged on its tantalizing course, so that I was able to take leave of my friends day after day. They rejoiced with me that the result of my efforts in New Zealand had been to raise over $£ 20,000$, the largest sum ever subscribed by local Jewry for a Jewish cause, to the apparent discomfiture of the Rabbi, who, in his New Year sermon, and in violation of his promise to help, had ridiculed Zionism as a myth and a will-o'-the-wisp. At last, after four days of conflicting rumours, the official announcement came that the Moeraki would definitely leave at five o'clock; and punctually the vessel now did leave, with the settlement of the strife transferred to Sydney.

Among the passengers there was a Christian lady who introduced herself to me on the strength of having heard my speech in the Wellington Town Hall, and told me that she was travelling to Palestine. Her husband was a firm believer in the British-Israelite doctrine, who, soon after the redemption by Lord Allenby of the Holy Land, had hastened thither and bought himself a house and plot of land at Haifa, where he proposed to engage in trade. He had cabled to his wife to join him with their family, and thus she was now journeying with her three children and a maid and all their household goods to realize what had been her dream as well as that of her 


\section{THE JOURNAL OF A JEWISH TRAVELLER}

husband. She asked me what the country was like near Haifa, and as I described the pleasures of the ascent to Mount Carmel, the wooded groves and sweet-smelling air on its spacious summit, the opalescent sky above and the deep-blue waters of the wide sheltering bay below, she uttered a prayer that the Almighty would bring her and her dear ones safely to the haven of her desire. 


\section{CHAPTER XIV}

\section{SYDNEY REVISITED}

FTER a month in New Zealand I returned to Sydney and had various interesting experiences, of which some stand out more particularly. The wife of a wealthy gentleman, from whom I was anxious to obtain a large donation, invited me to dinner, but two days before the appointed event she telephoned to me at the hotel, and said she had been unable at such short notice to secure any other guests for that evening, and she was afraid it would be dull for me to be alone. I replied that I would not mind that at all, and should be able to appreciate the excellence of her company and that of her husband all the more, for I at once concluded that I should be able to button-hole the latter after the repast. As soon as I arrived at the house I was ushered into the dining-room, and just as we approached the close of a gratifying meal my hostess announced that to spare me from ennui they had booked seats at the theatre for the three of us, and we must hurry up or we should be late. So, gulping down my coffee, I was hustled into the waiting car which sped us to the theatre, and I wondered how to broach the delicate subject.

The play was a thrilling war-time melodrama, with naval officers, German spies and submarine communications with Potsdam, so that in the intervals, both after the first and second acts, there was no time for more than an exchange of views with my host and his wife concerning the probable developments. But immediately after the third act I produced a number of snapshots 


\section{THE JOURNAL OF A JEWISH TRAVELLER}

that I had taken in Palestine, showing scenes in the Jewish colonies, which evoked the admiration of my companions, but before I could gently lead the conversation to the question of the Palestine Fund, up went the curtain again, and we breathlessly awaited the denouement. The diabolical plans of the spies were duly thwarted, and the naval hero was rewarded with the heart of his lady-love, whilst I was left pondering how to resume most tactfully the question that was my dominating concern. I thought that my host would take me back to his house for a little chat, but instead, he asked me at what hotel I was staying, and passed the name on to the chauffeur, so that during the few remaining minutes I was able to do little more than express my grateful appreciation of the enjoyable evening I had spent, and my regret that I had had no opportunity of enlisting my host's support in favour of the cause that had brought me to Australia.

"That will be all right. You needn't worry," he said reassuringly, as I took leave of him and his wife and passed into my hotel, reflecting sadly upon his successful tactics. I thought that I had been astutely outwitted, and that my hope of a big donation was doomed. But the following morning I was handed a letter which came from my host of the previous evening, containing the welcome announcement of a handsome contribution. A few hours later I happened to meet him, and whilst I thanked him for his generosity he laughed at the tantalizing experience I had undergone.

Another experience was more painfully tantalizing. I was invited by a gentleman to spend a Sunday evening at his house and asked to be there at eight o'clock. I thought that the hour was a little late for dinner in Australia, but as he and his family were coming up that day from the country I concluded that they could not conveniently dine earlier. I therefore donned a dinnerjacket and arrived at the house, as the clock struck eight, with a perfect appetite, as I had only had a slight 
tea over three hours before. My host greeted me smoking a cigar, and with an unmistakable air of self-satisfaction. He offered me a cigar too, and bade me feel at home in his cosy drawing-room, when suddenly, as I noticed him licking his teeth with the tip of his tongue, the idea flashed upon me with horror that he had already dined and wined. The conversation rather flagged on my part when this grim divination was confirmed by the lapse of time, and after discussing for an hour the prospects of increasing the local collection, what time the pangs of hunger began to assail me, I wondered whether I should rise to go, and explain that I should otherwise be too late to get anything to eat at the hotel. But courage failed me, and I remained glued to my chair, with hands folded on my ravenous stomach, refusing a second cigar, and wondering whether I should suddenly confess my hunger. But such an announcement would have created such a scene that I quailed before the prospect, and I resolved to go on bravely enduring this Barmecide feast until help would come. At last, after two hours and a quarter of silent torment, relief arrived in the form of some sandwiches and cakes, and never was there such rapid demolition of refreshments as then ensued, or such gratitude for the Australian institution of ten o'clock sandwiches.

Among those who helped me most beneficially with advice was Mr. Aaron Blashki, who suggested one day that I should pay a visit to Tattersall's Club, and try to obtain contributions from the Jewish bookmakers. I went to the club and saw the chairman, a grey-bearded Christian gentleman full of sympathy, who readily agreed to permit me to approach the members, and advised me to call a few days later, when the settling after some important races would take place. I gladly availed myself of the unusual opportunity. Mr. Sol Green, of Melbourne, who had subscribed $f 500$ himself, and who is one of the most popular figures on the race-courses of Australia, took me under his wing and introduced me 


\section{THE JOURNAL OF A JEWISH TRAVELLER}

to a few co-religionists. These were fewer than I imagined, but they all promptly gave me a little sheaf of notes without the preliminary skirmish that I had usually to face.

"If Sol says it's all right, that's good enough for me," said one Jewish turf agent, sitting in front of a pile of banknotes on the table. Then, turning to a fellowmember who was looking on curiously, he said: "I say, you've got a Jewish 'boko,' although I don't know whether you are a Jew."

"Well, I'm a bit of a one," replied the other shyly, " now you remind me of it."

"Then shell out, my boy," was the fraternal command.

The response was immediate and satisfactory, whereupon a Christian friend, remarking, "I don't see why I should be out of this," also gave me a few pounds. Within fifteen minutes I had collected $£$ roo. Seldom have I experienced such a manifestation of good-hearted generosity as in that brief visit to a racing club.

During my third and last stay in Sydney, prior to my journey northward, I dined with the Speaker of the Legislative Assembly, the Hon. Daniel Levy, in his official apartments. Mr. Levy had aroused a certain amount of criticism because, after the election of 1920 , which found the Nationalist and the Labour parties exactly equal in numbers, he, although a Nationalist, consented to continue acting as Speaker, and thus, by giving the Labour party a majority of one, enabled it to form a Government. It was urged that this was an act of disloyalty to his party, but Mr. Levy contended that the Speakership in Sydney should not be terminable at a general election any more than it was at Westminster. Had he declined to continue in the chair there would have been a deadlock, for if either party had put one of its own members into the chair it would have rendered itself a minority. And, indeed, it was not until Mr. Levy resigned the Speakership in the spring of I922, as a protest against the extravagance 
of the Labour Government, that a new general election was held, which brought the Nationalists back into power.

Mr. Levy, who is one of the many old pupils of the Jews' Free School in London who have risen to fame, afterwards provided me with a seat in the visitors' section of the Legislative Assembly, so that I might listen to the speeches. The subject under discussion was a local industrial problem, and as the oratory was poor, the interruptions rather many, and my seat not very comfortable, for the upholstered bench was well worn, I retired after an hour's patient endurance.

My farewell address, on the theme of "Civilization and the Jews," was delivered in the King's Hall, where Mr. Speaker Levy presided over a large gathering. Fortunately I was spared the disconcerting applause to which I had been subjected there on the last occasion; but in the course of my speech, as I narrated the acts of persecution committed against the Jews in Russia and other East European countries, somebody called out: "What about Bolsheviks?" It was a rude reminder that in Sydney, as in other parts of the world, the legend prevailed that the Jews in Russia were responsible for the Bolshevik nightmare, and I cited an abundance of facts to disprove the malicious libel.

At the conclusion of the meeting I was invited into a little room behind the stage where the Hon. Mr. Levy, in the name of the Sydney Zionists, presented me with a handsome little gold watch, whose face showed the hours by Hebrew letters, and whose back was adorned with the Magen David. There were brief speeches of good wishes on both sides, and thenceforth that little Zionist watch became the treasured companion of all my travels. 


\section{CHAPTER XV}

\section{THE MINOR COMMUNITIES OF AUSTRALIA}

T HAD some brief but interesting glimpses of Jewish life in the smaller towns, in all of which I found that the Jews played an active, useful and 1 occasionally prominent part. A few hours' railway journey from Melbourne brought me to Geelong, formerly famous as a mining centre, which has a Jewish community numbering about a hundred souls. It has a small synagogue, which, as it is used only on the solemn days of New Year and Atonement, is in a state of good preservation ; but it was specially opened on the evening of my visit so as to serve as the meeting-place. The attendance was unusually good, for the occasion was unparalleled in the local history. The members of the assembly ranged from the octogenarian President to school children not yet in their teens; indeed, I was told that everybody was present except the youngsters and infants who had already been put to bed. The President was a jovial old fellow, who wore a comical tall felt hat which must have belonged to a fashion of thirty years ago, and sat in the wardens' box with stolid dignity and fixed smile. No sooner had I shaken his thin waxen hand than he asked me if I could tell him of the latest songs of Harry Lauder. I had to plead ignorance of the newest ditties of this Scottish minstrel, and drew upon me a look of the profoundest pity. "But just listen to this!" said his aged admirer, as he trolled forth some couplets, at which the younger generation gathered around all dutifully laughed. "Perhaps you 
can tell me some funny things after the lecture," he said, with a grandfatherly nod.

Throughout my discourse, delivered from the little platform in front of the Ark, I had the uncomfortable feeling that the venerable President was thinking much less of the pioneers of Palestine than of the bonnie lasses of Scotland, and that he was much more deeply impressed by the melodic art of Sir Harry Lauder than by the statesmanship of Sir Herbert Samuel. Now and again my remarks evoked the approving applause of the assembly, but the octogenarian occupant of the box, sitting immobile with vacuous stare, seemed to be utterly unconscious of the drift of my address. I was thankful that he remained silent at least until I had finished, and in order that the strain might not prove unbearable I compressed my speech to about half of its usual length. But as soon as it was over the venerable gentleman shared in the applause by tapping his stick on the ground, and afterwards he led in the financial responses to my appeal. The congregation had already collected a little fund for Palestine, but after my pleading several who had not yet contributed anything made good the omission, and most of those present pledged themselves to repeat their donations annually for the next four years, so that altogether $£ 500$ was raised, a fact of which a local reporter immediately hastened to inform his paper.

"I never paid so much to hear Harry Lauder," said the frail old President, with a slow and significant shake of the head.

" But it will do you much more good, dad," reassuringly added some of his numerous offspring.

From Geelong, accompanied by the President and the Secretary of the Victoria Zionist Organization, with whom I had travelled from Melbourne, I went to Ballarat, which likewise has a congregation of about a hundred souls. Years ago, when Ballarat was a booming mining centre, the Jewish community was large, but with the lapse of time and the gradual exhaustion of its gold 


\section{THE JOURNAL OF A JEWISH TRAVELLER}

deposits one member after another, and one family after another, began to migrate to some larger city-especially Melbourne or Sydney-so that the remaining members wondered how long they would be able to continue maintaining the financial burden of the congregation. We spent the morning in the beautiful and instructive Botanical Garden, which we reached through an avenue of young trees, all bearing the name of some local volunteer who had fallen in the Great War, whilst in the afternoon we attended a reception given by the Town Council of Ballarat, and then another by the Council of East Ballarat. In the Ballarat Council Chamber I saw an oil portrait of a Jew who had been Mayor of the city some sixty years ago. One of the members of the Council, in his speech of welcome, declared that he had never seen a Jewish farmer, and expressed doubts about the capacity of the Jews for the cultivation of the soil. He was surprised when, in my reply, I spoke of the Jewish fruitgrowing settlement at Shepparton, and especially when I described the Jewish agricultural colonies in Palestine, America and other parts of the world. At the reception in East Ballarat, which followed immediately upon the first, and was separated therefrom by little more than a five minutes' motor-car journey, I listened to a cultured eulogy of the Jew by the Town Clerk, who paid a thoughtful tribute to the life and work of Beaconsfield.

My meeting, which took place in the evening in the synagogue, passed off without any incident worthy of note. I was reminded that the last address on Zionism heard in that place of worship had been delivered by the late Mr. Samuel Goldreich, a nephew of the Rev. I. M. Goldreich, who had been the local minister for forty years, and whose memory was perpetuated by a marble tablet.

A few weeks later, after concluding my stay in Sydney, I travelled north and found myself after a three hours' run in Newcastle, which owes its name to its being a miniature replica of Newcastle-on-Tyne. The scenery 


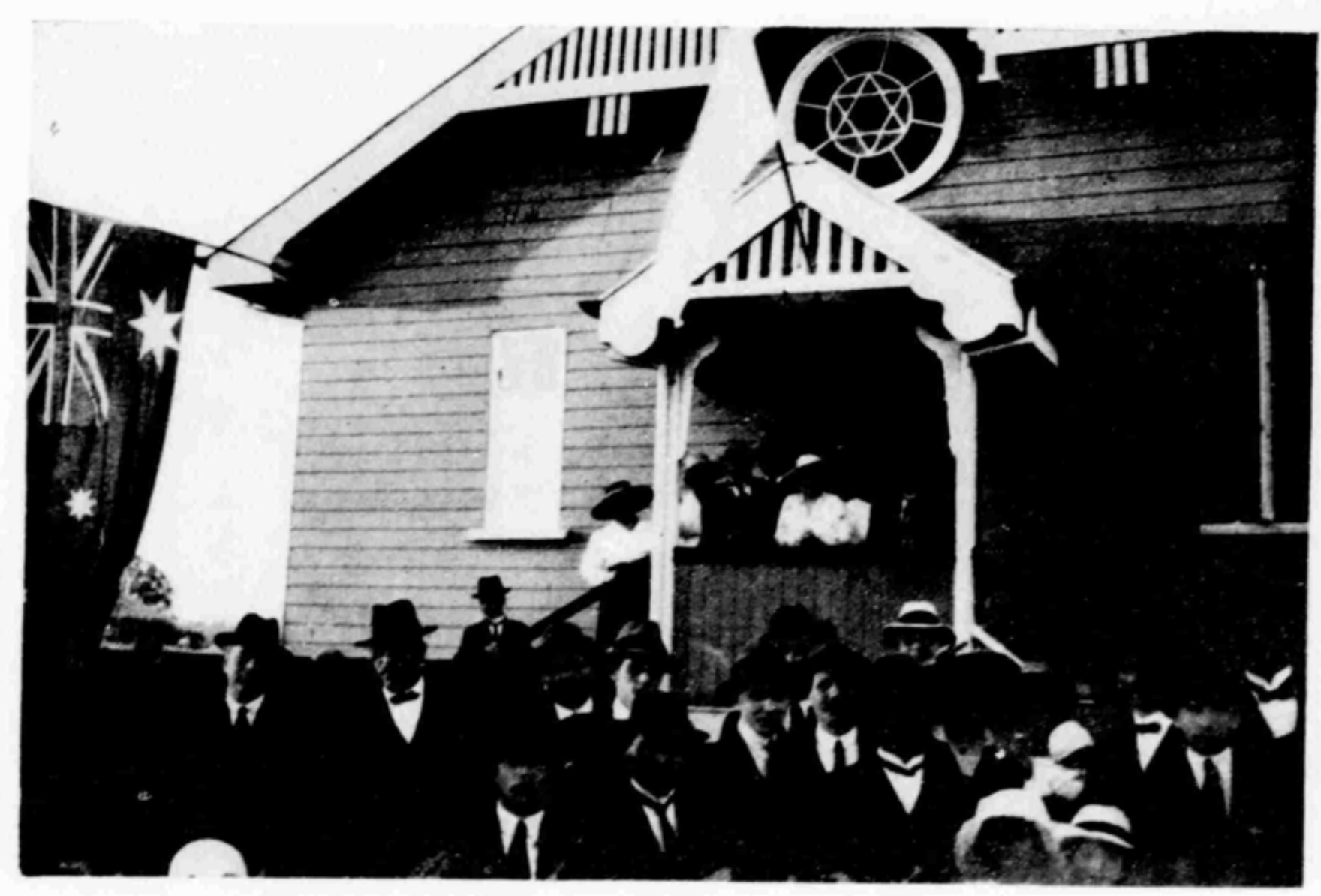

OUTSIDE SOUTH BRISBANE SYNAGOGUE.

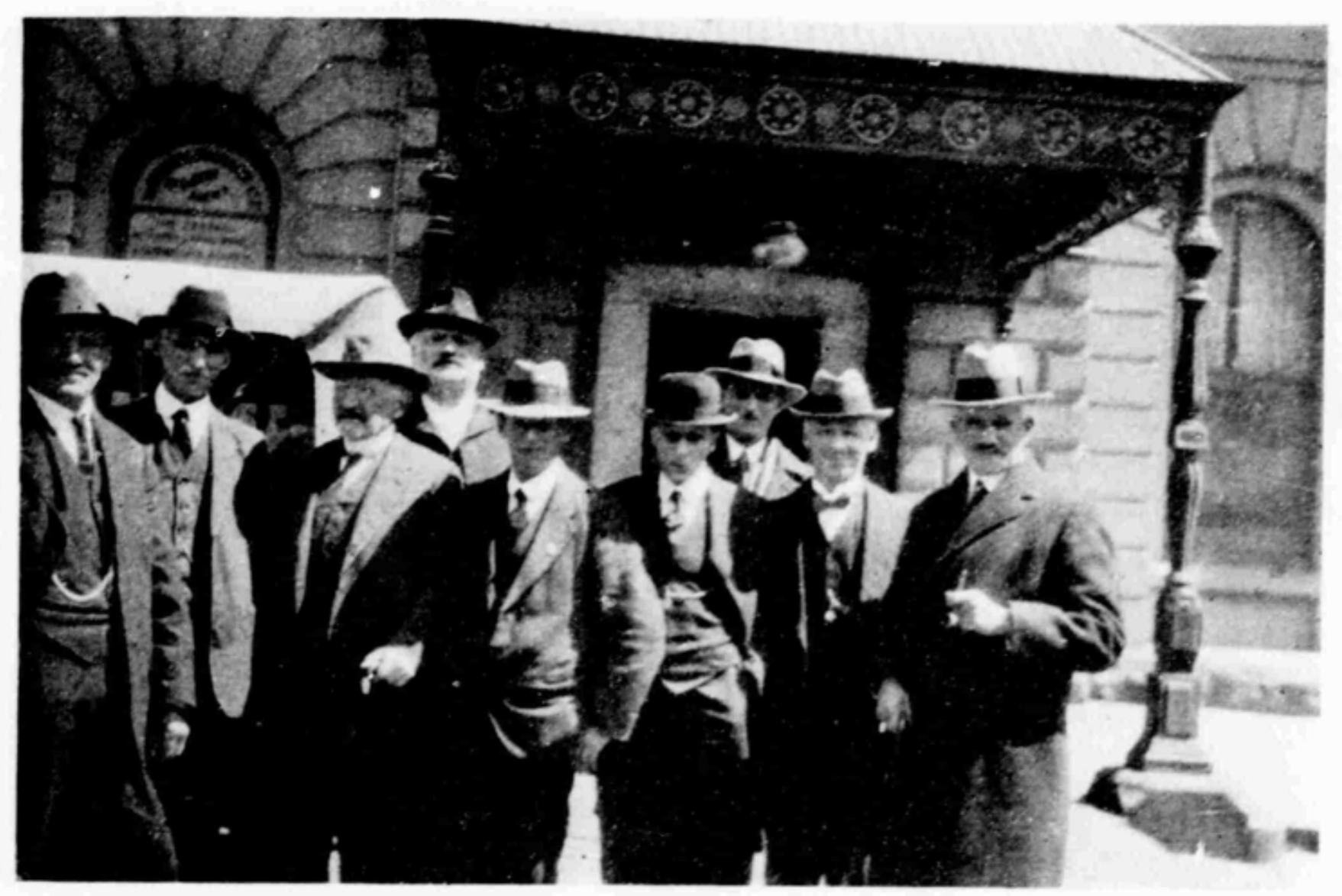

MEMBERS OF BALLARAT JEWISH COMMUNITY 


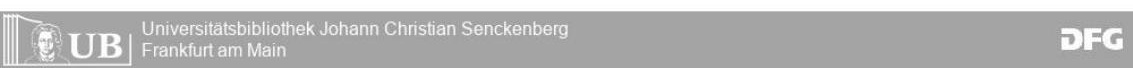


on the way presented in many parts a magnificent panorama; the train crossed a bridge over the broad bosom of the River Hawkesbury, which is bordered by the most luxuriant vegetation. Upon my arrival at the city I was met not only by a Jewish deputation, but also by the Mayor-unadorned by the emblems of officeand together we proceeded to the George Hotel, the principal establishment in the place, which was in the hands of a Jewish proprietor, and where the Mayor delivered a speech of welcome. The entire Jewish community did not comprise more than fifty souls, and although it did not yet possess a synagogue or a minister, it already boasted of a Zionist Society which had just been formed. The meeting, which was held in a mission hall, was open to the general public, so that the Jews were in the minority, but they naturally contributed the major portion of the local fund.

The last Australian city in which I spoke was Brisbane, which I reached after a twenty hours' express journey from Newcastle. From Woolangarra on the Queensland frontier I sat in a comfortable arm-chair in the parlour-car surveying the varying scene of woodland and fertile acres, but the pleasures of the journey were diminished by the heat and dust which gradually increased as we travelled northward. At Ipswich, an hour before reaching Brisbane, I was joined by three members of the Brisbane Zionist Council, who had journeyed south to meet me, and when at length the train drew up in the terminus I was welcomed by a great crowd, at the head of which, I was told, was the Minister of Education, the Hon. John Huxham. As the gentleman indicated had a rather plebeian appearance, and wore a cloth cap, it was somewhat difficult to realize that he was a member of a Cabinet. He welcomed me in the name of the State authorities, and offered me the free use of the State railways, a gift of which I was unable to avail myself, as Brisbane was my port of departure for China.

It was seven o'clock in the evening when I arrived, 
tired and travel-stained; at a quarter-past eight I was in the synagogue, addressing my first meeting; and within an hour and a half I had raised over $£ 2200$, headed by a donation of $£ 500$ from the leading Jewish familythe Hertzbergs. The proceedings began with the playing of Hatikvah by a small brass band in the gallery, in which the cornet was blown with exceptional vigour. It was the first time in the history of the community that the Jewish national anthem was rendered in public, and its performance, I was told, had been preceded by many rehearsals. The financial result of my appeal was declared to be beyond the wildest dreams of the most optimistic members, for there were only 500 souls in the entire community; and there were very few persons of wealth among them. Indeed, some strenuous efforts had been made to raise a few hundred pounds for the decoration of the synagogue in honour of the expected arrival of Sir Matthew Nathan, whose appointment as Governor of Queensland had recently been announced, but not even half of the requisite amount had so far been provided.

The Brisbane community bore a certain resemblance to that of Perth by virtue of the large number of Russian Jews in its midst, and this also accounted for a similar demonstrative enthusiasm. Many of these Russian Jews had reached Brisbane after travelling through Siberia to Shanghai, whence they had sailed southward, and some of them, on hearing that I was going to visit Harbin, entrusted me with messages for their relatives in that city. The Russian colony was concentrated mostly in South Brisbane, on the other side of the river that zigzags through the city, where it had its own synagogue-a modest wooden structure-called " the Russian Shool." The humble shrine was very gaily decorated with the British and Zionist flags on the Sunday afternoon on which I addressed its members, and the local Mayor, who presided from the little platform before the Ark, swelled with pride as he surveyed the scene. There were many children present, all in 
their Sabbath best, and some of the little girls not only had pale-blue ribbon in their hair, but also pale blue Magen Davids sewn on to their white frocks. There was a spirit of friendly rivalry in the responses to my appeal, and the applause that broke forth when I announced that we had reached the sum of $£ 3000$ made the rafters ring again.

The few days that I spent in the city were crowded with a variety of functions, all of which, with perhaps one exception, have left a pleasant memory. At the City Council Chambers I was given a civic reception, at which the Mayor, aldermen, clergy and others united in their praises of the Jewish people, and in wishes for the success of my mission. The oldest member of the Council, Alderman M'Master, a striking figure with patriarchal beard, declared: "I am an Israelite. I believe that the British nation is part of the Lost Ten Tribes of Israel," and he rejoiced that he had been able " to live to see the Jewish nation come back to its own inheritance." The believers in the British-Israelite theory formed quite an active fraternity in Brisbane. One of them, a retired policeman, had followed the creed to its logical-and theological-conclusion by adopting Judaism : he had acquired a knowledge of Hebrew, and prayed in the synagogue far more regularly than most of its members. Another diligent worshipper was a Christian who claimed that he was to be the Messiah, but the community regarded this as just an amusing pretension, and took no steps to test its validity.

The only function that left me unsatisfied was a public meeting that I addressed in the Albert Hall, and at which the Mayor presided. Of all the numerous occasions on which I spoke in all the lands through which I travelled, that was the only one on which my speech was not marked by even the faintest applause from beginning to end. It was a most trying ordeal to deliver an hour's discourse, in which I described the history of the efforts aiming at the restoration of the Jewish people in Pales- 
tine, and recounted the whole cycle of sufferings that had stimulated those efforts, without receiving or perceiving the slightest manifestation of sympathy or approval. A solemn silence settled upon all my listeners, unbroken by a single cheer, or even a single cough, as though I were delivering a sermon; and, indeed, I was afterwards told that the audience had regarded my address in the nature of a sacred lecture, which it would have been irreverent to interrupt by any mark of approbation.

The Sabbath was rendered unusually agreeable and memorable by the Friday night supper given by the Zionist Council in the house of one of its members. The table was decked with Zionist colours, and blue and white streamers spread from a blue and white Magen David attached to the candelabra. Two huge plaited loaves were placed at the end of the table, upon which I had the honour of pronouncing the traditional benediction; and after an enjoyable repast composed of all the familiar dishes of the Sabbath menu, the whole company - some fifteen persons-joined in the singing of the Shir Hamaaloth ${ }^{1}$ to the tune of Hatikvah. Many friends arrived after the meal, and there was a plenteous exchange of anecdotes and experiences, affording glimpses into the peculiarities and vagaries of Jewish life in Australia.

The following morning I was in the synagogue again. It was a simple service, but one that I shall never forget. For the Hazan, who had read and sung in that shrine for so many years, and prayed for the return of Israel to his land, was leaving in a few days to journey to that land himself. Whether it was because of grief at parting from his many friends, or of joy at the nearing fulfilment of his life's ambition, his voice was often choked, and his last rendering in that familiar scene of the Sabbath praises was broken by many a sob. ... A few months later I met him with radiant face in a sunlit avenue in Tel-Aviv.

On the last day of my stay I was entertained to lunch 1 Psalm cxxvi. 
at the house of the treasurer of the Zionist Council. He was a Russian Jew, who had a prosperous cabinet factory, and he told me with pride that he had established it some years before the war with only $£ 30$. His progress was typical of that of many other members of the Russian colony. It was a homely repast, at which many friends were present; almost everybody delivered a speech to toast somebody else's health, and every response was preceded by the singing in chorus of "For he's a jolly good fellow," which was always led by the same mana short, rubicund individual-in a deep bass and with tragic seriousness.

My mission to Australia was over, and, after these months of feverish toil, I looked forward with relief to the pleasant voyage through tranquil waters that I was to begin that night. I had raised $£ 58$, 000 among the I8,000 Jews in the Commonwealth, and I was told that this was an event without precedent in its annals. The local Press gave prominence to the news ; it was telegraphed throughout the Continent; and Reuter cabled it throughout the world.

At nine o'clock I went on board the Tango Maru, the Japanese steamer that was to take me to Hongkong. It was a fine starlit night, and a big gathering of my newly made friends, men, women and children-and even babes in arms-were assembled on the wharf to see me off. As I stood on the deck they threw multicoloured paper streamers at and around me, which I fastened to the rails, so that soon there was a motley network connecting me with the people below. The steamer did not sail for an hour, but the interval soon passed with the exchange of final greetings, with an occasional speech from the wharf, and a response from the deck, and with the repeated singing of Hatikvah. Many little Zionist flags were waved by young and old, and the large flag that I had presented to the society was unfurled aloft, to the wonderment of my fellowpassengers. At last the vessel slipped its moorings and 


\section{IO4 THE JOURNAL OF A JEWISH TRAVELLER}

began to glide away, and the streamers snapped and fluttered. Again Hatikvah was struck up with fervour and gusto by the entire throng, and its strains were borne across to me on the breeze as the gap of moonlit water between ship and wharf became wider and wider, and the singers dwindled away into the tiniest of specks. 


\section{CHAPTER XVI}

\section{THE PHILIPPINES}

I

FTER the rough passages that I had weathered
in the Indian Ocean and the Tasman Sea, the
northward voyage from Brisbane, within
the Great Barrier Reef, reconciled me to the water, for it was an experience of unruffled calm and unalloyed delight. The Tango Maru, the first Japanese steamer on which I sailed, was a comfortable vessel with punctilious service, and as the number of passengers was not large life on board was restful and agreeable. My cabin companion was a young Dutch Jew, who was in the Civil Service in Java, which he always spoke of as "India," and who had been studying the work of educational institutions in Australia prior to his return, after seven years' absence, to Holland for a holiday.

Three days after leaving Brisbane we anchored at Townsville, the outlet of a big sugar-growing district, whose customary torpor had been rudely disturbed a few weeks before by an abortive Bolshevik rising against the local authorities. There was no sign or echo of the sensational episode as we strolled through the sunscorched streets, where, apart from the general appearance of primitive development, the most striking phenomenon was the unwonted number of able-bodied idlers, who clustered round the doors of public-houses like flies round a jam-pot. I soon discovered a portly Jew, a prosperous merchant, who had been living in Townsville for twenty-five years, and who, although a native of Germany, had secured such a hold upon the 
affections of his fellow-citizens that he was not molested during the war. He told me that there were only four other Jews in the town, a number far from sufficient to provide a basis for Jewish communal life, and he therefore looked forward to spending his retirement in the more congenial environment of Sydney.

After another three days of smooth and somnolent sailing, during which we were within sight of the mainland all the time and picturesque isles with strange foliage emerged on our right every now and again, we reached Thursday Island, the home of the pearl-fishing industry, where we stayed a few hours. It is a small tropical port, with a primitive wharf, the approach to which was dappled with boats, whence bronzed white men, blacks and half-castes, the curious offspring of commingling races, were lazily angling in the placid waters. The scene on land-it was a Sunday morning-was one of unutterable loneliness: there were a few rough streets of timber houses with verandahs, and one or two shops. Over one of the latter appeared the name Mendis, which I thought might betoken a Sephardi, but upon entering I found that the owner was a Cingalese. He had a miscellaneous collection of local products-blister-pearls and emu eggs - of which I bought a few specimens; and from the counter I picked up a copy of the local newspaper, a single tiny sheet, which was issued weekly with a batch of stale telegrams.

It grew hotter daily as we continued our course, and as we passed the island of Ceram a swimming bath was rigged up on the lower deck. Ten days after leaving Brisbane we crossed the Equator at noon, an event that was marked by no other rite than the blowing of a shrill blast with a whistle from the helmsman's bridge. Before us now stretched the quaintly shaped island of Celebes, from whose midst rose a pyramidal mountain with flat summit, whose likeness to Fujiyama was remarked by our Japanese officers. There was a glorious sunset that evening, and as though to vie with the wealth of brilliant 
colour in heaven the deck was illuminated with little red and green lamps, beneath whose motley radiance many passengers disported themselves in fancy dress and danced to jazz measures churned out of a gramophone. On the morrow we all had a strange feeling of drowsiness and exhaustion, and lounged in deck-chairs beneath the pale grey sky, whilst, with a writing-pad on my knees, I persevered at the task of chronicling my impressions of the Judean colonies ; and it was therefore with the relief of prisoners on the eve of release that, twenty-four hours later, we approached the harbour of Zamboanga, the first port of the Philippines. Halfclad dusky natives came rowing out to us swiftly in their sampans, and begged for silver coins to be thrown into the water, whereupon they dived deftly after them, and soon clambered back in their thin dripping garments, displaying the gleaming coin between their teeth as a challenge to $a^{\prime}$ fresh feat of daring dexterity.

We stayed only a couple of hours at Zamboanga, but it was long enough to gain an impression of the indolent life of the paradisaical spot, semi-Spanish in character, with its avenues of luxuriant palms traversed by curious little carriages in which the inmates were curtained off from the heat. A brown urchin accosted me at a street corner and offered to sell me a patterned kerchief, and upon stopping to examine it, he revealed in its folds the real object of merchandise-a goodly sized pearl, which he claimed to be genuine and offered very cheap. On the other side of the road I was attracted to a small fruit-shop, above whose window was painted the name of Moise Tanin. I entered it and found that the owner was a Syrian Jew, a middle-aged man, whose melancholy face beamed with happiness when he learned that I too was a Jew. He had lived in Syria until some months after the outbreak of war, when he fled with his wife from the repressions practised by the Turkish Generalissimo, Djemal Pasha, to Egypt, and after seeking his 
IO8 THE JOURNAL OF A JEWISH TRAVELLER

fortune among his brethren in Bombay and Singapore was swept by fate into this tropical retreat.

"And are you doing well ?" I asked.

" We are just able to live," he said. " But it is not like life in my native home. We feel here in Galuth, ${ }^{1}$ for there is no other Jew here. Soon we hope to be able to go back, not to Syria again, but to the land of Israel. Tell me, is it really true that England has given us back again our land?"

"England rules the country, and we can go back to it and rebuild it, but it is not yet ours," was my reply.

A look of sadness flitted across his face. "So we must still wait for the Messiah," he said, with an air of resignation.

\section{2}

We were scheduled to reach Manila two days later, and as we continued our halcyon cruise I learned that the Philippine Islands, which the ordinary maps showed to be not more than half a dozen in number, comprised fully 3000 , though many of them were uninhabited and had even never been explored. In anticipation of our next landing I studied a Manila Directory in the ship's library, with a view to discovering the names of some Jews upon whom I could call. Experience had taught me that not every name that appeared to be Jewish was borne by a Jew, but after a careful examination of all the patronymics of the commercial and professional inhabitants, I noted down a few names and addresses of the most likely persons, headed by Colonel Joseph $\mathrm{N}$. Wolfson, Attorney-at-Law. The Tango Maru arrived at Manila early in the morning, and as it was to stay in port until the following day, I conceived the plan of arranging a meeting of the local Jewish community for that evening.

No sooner had I landed-thanks to the American visa for which I had paid an exorbitant fee of nearly

1 Exile. 
$£ 3$ in Sydney-and threaded my way through the crowded bustling wharf into the street than I hired a motor-car and drove through busy thoroughfares to the address of Colonel Joseph N. Wolfson. But upon arriving at the place given in the Directory I could discover no trace of the Colonel's office, and was about to instruct the driver to take me to the next person on my list, when I caught sight of a printed notice on the wall giving the new address to which the Colonel had removed. I was soon tramping up the bare wooden stairs that led to the attorney's office and handed my card to a native clerk.

Colonel Joseph N. Wolfson was right glad to see me. He was an elderly, sallow-faced, clean-shaven man, with large horn-rimmed spectacles, and with a long cigar in his mouth which he chewed rather than smoked. He leaned back in his chair and listened with a mingled air of surprise and scepticism as I told him of my travels and expressed a desire to explain my mission at a meeting of the Manila Jews. But when I opened my little black portfolio and produced my letters of introduction from Lord Milner, Sir Herbert Samuel, Sir Alfred Mond, Lord Rothschild and others, all signs of doubt vanished from the Colonel's visage, which now lit up with a smile of gratification.

"These are the very finest credentials that I have ever handled," he said, chewing his cigar with gusto and proffering me one. He lingered over Lord Rothschild's letter, which was in autograph. " So this is Lord Rothschild's writing," he remarked in a deferential tone. "A great man, Lord Rothschild! And what's good enough for him and these other big folk should be good enough for the Jews in Manila. But "-with a vicious chew at his cigar- " you don't know the Jews in Manila."

"What do you mean, Colonel ?" I asked.

"Two years ago I was sent for by the GovernorGeneral, who told me that he had received a letter from the Zionist Organization of America, asking him to get into touch with the leading Jews in this city, with a 
view to raising funds for the rebuilding of Palestine. He asked me to take the job in hand and I did. I spoke to quite a number of Jews, but they simply wouldn't hear of it, and not a single goddamn cent did I get. If you think you can do any better I wish you luck, my boy, and I'm willing to help you. But you are up against a tough proposition, and you can't do much in twenty-four hours."

Thereupon the Colonel enlightened me upon the conditions of local Jewry. They numbered a few hundred and came from various countries-America, Russia, France and Germany, but although most of them had been settled in the colony for twenty years-in fact, ever since the American flag had been planted there-they had not yet joined together to form an organization or build a synagogue. The American Jews would have nothing to do with the Russian, the French would have nothing to do with either, whilst the Germans said they would come in only after all the others had become united. Consequently there was no Jewish organization or institution of any kind. If a Jew wished to get married according to Jewish rites he took a two days' trip to Hongkong, where there was the nearest synagogue; and if he died his family or his friends had him buried in a Christian cemetery. But twice a year-on New Year and the Day of Atonement-the sluggish embers gave a feeble flicker, and a religious service was, held in a hall and attended by a number of Jews whose racial consciousness was not yet extinct. A beginning had indeed been made with the raising of a fund for the building of a synagogue, but the amount collected was far from sufficient for the purpose and the prospect of its increase seemed "goddamn" remote.

"However," said the Colonel, with another bite at his cigar, "you are here on another job, and perhaps you'll' be able to tickle 'em."

He then gave me the names and addresses of a few other Jews, headed by that of the gentleman who was 



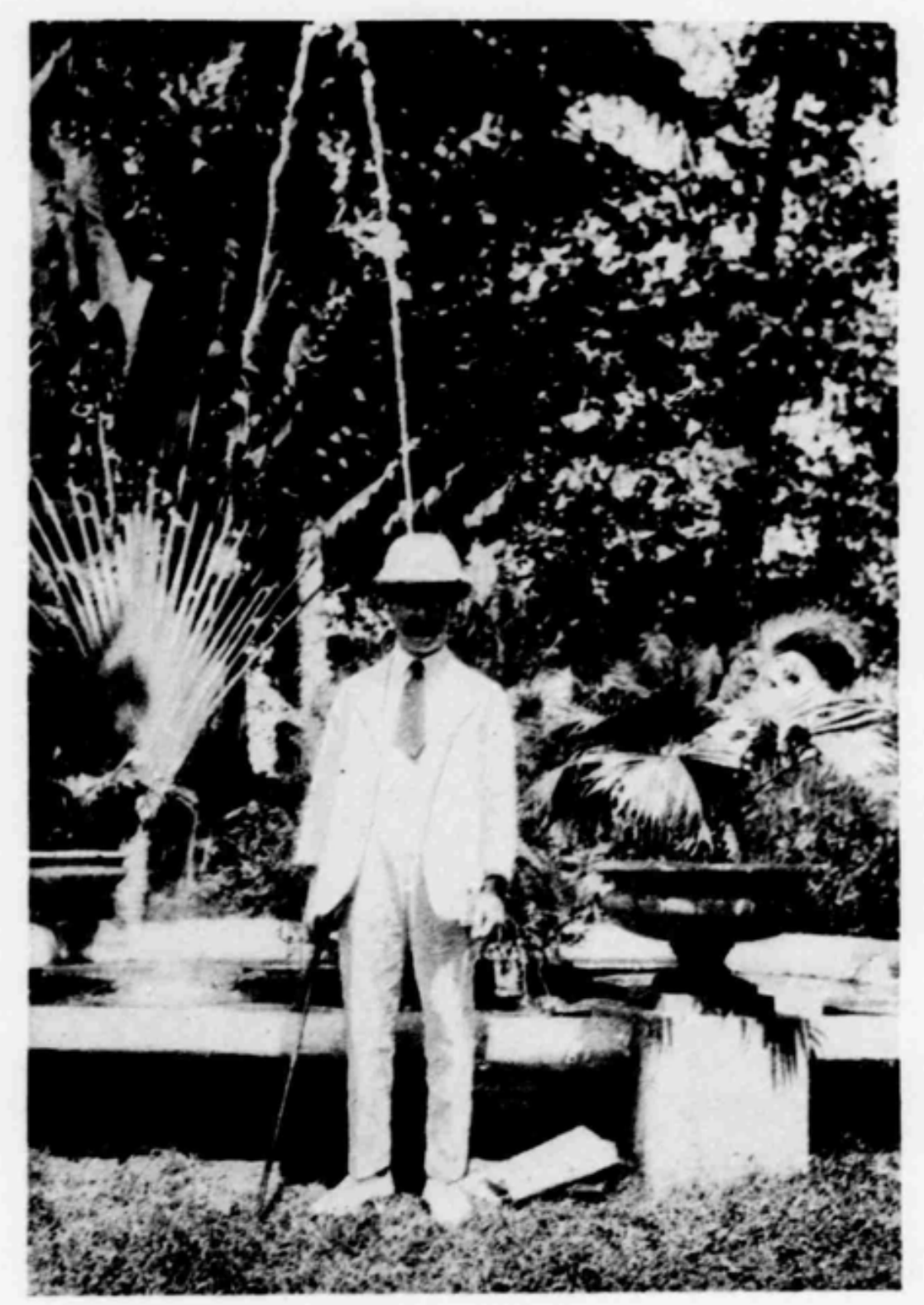

AT ZAMBOANGA

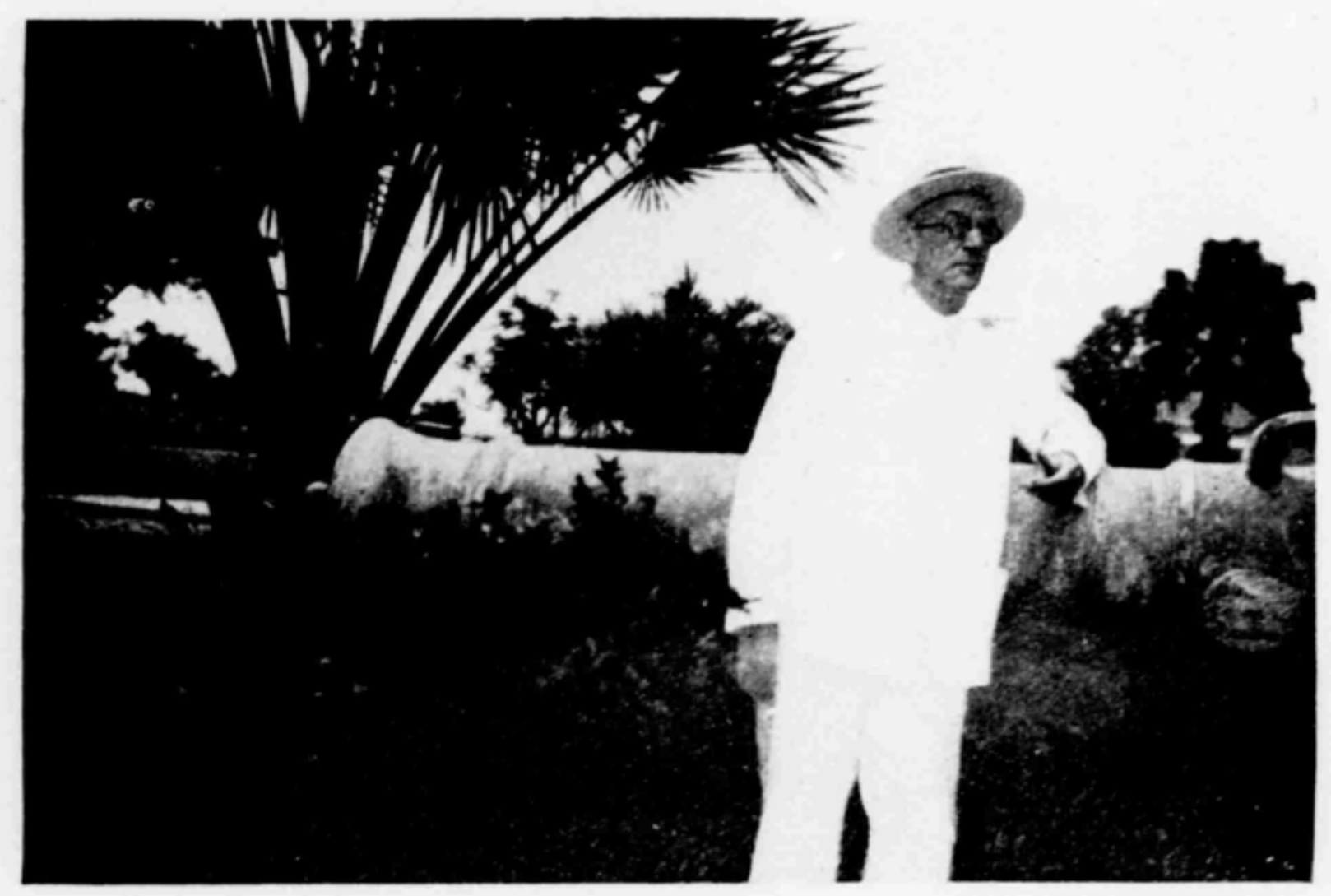

COLCNEL JOSEPH N. WOLFSON, MANILA 
known as the Gabbai or Warden, because he presided at the annual revivals; and he undertook, if there were sufficient promises of attendance, to secure a hall in the Cosmopolitan Building for our meeting in the evening. But he adjured me not to say a " goddamn " word about his being the source of my information or about the part he was playing in this "stunt," and asked me to come back for lunch.

The Gabbai was the owner of a small store not far away. He was a middle-aged man of Russian origin, who spoke with an American accent. He readily approved of the proposed meeting and evidently felt flattered to be reminded of his office on an occasion quite unconnected with the Days of Penitence. He promised not only to attend-" to hear a Jewish word," as he put it-but also to induce some friends to come, and he then directed me to another Jewish storekeeper. The latter was also of Russian origin and likewise amenable to the plan. "It's time something was done to wake up Jewish feeling in this heathenish place," he said regretfully. Then, pointing to a young man with prominent cheek-bones and dark moustache, who came in on business, he added: "Here's another Jew for you," as though I were engaged upon the salvation of souls.

" I'm not a Dzew," said the young man, with a deprecatory wave of the hand.

"What are you then?" I asked. "A Filipino?"

"That's good," chuckled the storekeeper. "He's got you there, Abe."

I then called at one or two high-class jewellery shops that were kept by French Jews, but although I was received with polite bows I was told that dinner engagements would prevent attendance at the meeting, for the success of which the very warmest of good wishes were profusely expressed.

I returned to Colonel Joseph $\mathrm{N}$. Wolfson and reported the result of my morning's activity. He took me in his car and drove to the Army and Navy Club, pointing 
out on the way the huge Spanish wall of the inner city and explaining the remarkable changes that had taken place since the American occupation. At lunch the Colonel discoursed upon his pedigree, his successful career, and his multifarious experiences. $\mathrm{He}$ was a native of Louisiana, and grandson of a German Rabbi who had long passed away, and he had won the rank of Colonel in the Spanish-American War which had first brought him to Manila. After the meal I took a snapshot of him outside the Club, as he posed in white suit and straw hat against a cannon which had been used by the invading forces. Then I drove in a tropical shower to another co-religionist, a wealthy manufacturer of motor-cars, whose works were situated on the outer periphery of the city. The latter was a Russian Jew who had stafted life in the Philippines as a pedlar in watch-glasses and had developed into the proprietor of a prosperous business. It was he who fathered the project of a synagogue and headed the fund with the largest donation. Although sympathetic to the cause of Palestine he first wished to see the realization of his local aspiration, but although he would not promise any material support at present, he agreed to come to the meeting in the evening.

In due course the meeting took place. It was the most unconventional and least profitable gathering that I addressed in the whole of my tour. It was attended by exactly six Jews and by a Christian reporter of the Manila Times, who had been specially invited to record the memorable function. We met in the Moose Hall, Cosmopolitan Building, which was large enough to accommodate an audience of a few hundred. Colonel Joseph N. Wolfson was unanimously voted to the chair and presided over the proceedings with genial dignity. After I had spoken and appealed for donations it was suggested that it should be left to the Colonel to collect what he could after I had gone. But I insisted that a 
beginning must be made by those present, so that an example might be set to those who would be approached later. Thereupon the chairman declared that he would open the list with a donation of 5000 pesos if I could repeat his name. son."

"That's simple," I said. "Colonel Joseph N. Wolf-

"Oh, no, that's not all," he replied. " Just listen carefully, if you want to win the money." And then, taking a deep breath, while all the company smiled in expectation, he said: "My name is Josephus-AdolphusEmeritus-Vesputius-Leonidas-Naphtalicos-AlexandrosLucius-Quintus-Cincinattus-Wolfson."

These names were rattled off so rapidly that it was utterly impossible for me to repeat more than half. They reminded me of the ten sons of Haman, whose names, in token of their simultaneous execution, are gabbled off in a single breath by the reader of the Book of Esther on the Feast of Purim.

"There you are, my boy," said the Colonel triumphant. "That was a fair offer, and you've lost." His friends joined in his laughter.

I tried to bring these men back to a sense of the seriousness of the cause at issue. I urged that the restoration of the Land of Israel could not be made dependent upon the solution of conundrums. I bade them redeem the reputation of their chaotic community by a collective act of generosity, if not of self-sacrifice. The Colonel and the Gabbai, apparently moved, withdrew for a private conference, and after a few moments returned. The Gabbai announced that he would give 200 pesos. At last the ice was broken, and the others offered smaller amounts. The wealthy manufacturer of motor-cars said that his heart had been deeply touched, but he could not give anything until the synagogue was built. And Colonel Joseph $\mathrm{N}$. Wolfson, declining to name his donation, said that he would give an amount equal to the highest that he would obtain in the community. He was 
II4 THE JOURNAL OF A JEWISH TRAVELLER accordingly empowered to take charge of the collection, and the historic meeting dispersed.

The Colonel then drove me in his car in the pelting rain back to the harbour so that I might return to the ship. Only after I had left him and trudged for some distance along a muddy road did I discover that I had unwittingly been taken to the wrong wharf. Owing to the darkness and the rain hardly a soul was about, and with difficulty I found my way with the help of a stolid. native policeman. I was clad only in a thin linen suit, and by the time I clambered up the ship I was drenched to the skin.

As the vessel ploughed its way on the morrow through heavy seas to Hongkong I could not help reflecting upon the closing scene of my adventure and regarding it as ominous. Alas, my forebodings have been fulfilled. For after an interval of over three years only a fraction of the pledges has been redeemed, whilst from those who were not present at the meeting not even a promise could be extracted. . . . And thus I am left wondering whether all the fortunes of the rich Jews of Manila are worth the soul of the one poor Jew of Zamboanga. 


\section{CHAPTER XVII}

\section{HONGKONG}

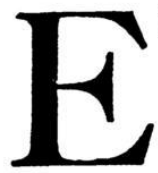

IGHTEEN days after the Tango Maru left the Brisbane wharf it glided one misty afternoon into the picturesque harbour of Hongkong. It was a peculiar coincidence that I had sailed direct from a British colony that was expecting a Jewish Governor to another colony over whose destinies that selfsame Governor, Sir Matthew Nathan, had presided several years before. In Brisbane there was speculation as to the possible success of the new administrator; in Hongkong there was nothing but praise for the efficiency and popularity that had distinguished his period of office. Much of the progress that had marked this vital outpost of the British Empire, I was told, was made under the wise and zealous guidance of Sir Matthew Nathan, to whom especially was due the construction of the important railway through various tunnels to Kowloon. The beneficent effect of his work, after so long an interval, operated indirectly to the advantage of my mission, for a people that could produce such an able Governor for others, it was locally argued, would have no lack of gifted administrators for the development of its own National Home. And so my plea, in this farthest spot of British Asia, for the rebuilding of another little strip of Asia under British tutelage, fell upon sympathetic ears.

There was another coincidence that marked my arrival in Hongkong. At the very same moment a $P$. and $O$. vessel had anchored at another wharf, having on board the first Rabbi who had come from the West to be a spiritual guide to his brethren in the Far East. It was Rabbi W. Hirsch, who had left his congregation in the 
North of England to accept the call of the growing community at Shanghai. His ship was staying at Hongkong until the following morning, so the members of the local congregation arranged to give him a fraternal welcome. Together we were driven through the crowded thoroughfares to the Jewish Recreation Club, which is situated in the more elevated part of the city, and we exchanged impressions and experiences on the way. The streets, though thronged, were strangely hushed, for there was no horse traffic, the principal vehicles being the rickshaws drawn by bare-legged, thick-calved coolies, which ran as smoothly and silently as on a track of felt. The road to the Club was steep, for the whole of the prosperous district in which it is located has been ingeniously built up on the sides of hills and mountains ; and when we arrived at our destination, still far below the summit of the Peak, a veritable feast spread before our eyes as we gazed at the harbour below, for it was as resplendent as a Swiss lake, encircled with wooded hills, jewelled with green islands, and dappled with ships, junks and a swarm of curious sea-craft.

The Club was the finest Jewish institute of the kind I have ever seen, for all the clubs of English Jewry that I know belong to the "working-men's" category, whereas this was equipped with something of the comfort characteristic of a social or political club in the West End of London. There was a large and tastefully furnished room with a grand piano, which could serve as drawing-room, concert hall and lecture theatre ; there was a reading-room, supplied with a select library and several of the leading Jewish newspapers; there was a billiard-room that was seldom neglected, and a bar presided over by a white-jacketed Chinese mixer who could dispense you any cocktail that you chose. Between the whole length of the building and the edge of the mountain there stretched a spacious, well-trimmed tennis lawn, which was a welcome boon during the unusually long summers and had its ardent and agile 
votaries every afternoon. The building was the gift of Mr. E. S. Kadoorie, a public-spirited philanthropist who first saw the light in Bagdad and who shed both light and kindness not only in the Far East, but also in his native city; in Constantinople, and in the Holy Land. Most of the members of the community belonged to the Club and visited it almost every afternoon, and its popularity as a social rendezvous tended to make it a more efficacious racial preservative than the synagogue which adjoined it.

As. I sipped my tea and chatted with the president, Mr. Edward Ezra, and the treasurer, Mr. David Gubbay, I learned something of the romance attaching to this community, for its origin was due to the spirit of commercial enterprise that was so sagaciously exercised by the Sassoons. The distinguished founder of their fame and fortune was David Sassoon (the scion of a stock known as the Ibn Shoshans in the Spain of Ferdinand and Isabella), who was born in Bagdad in I792 and removed forty years later to Bombay, where he founded the firm of David Sassoon and Company. He was blessed with eight sons and four daughters, and it was upon the loyal and energetic co-operation of his sons that he built up his prosperous and widely ramified business as bankers and merchants in the East, just as the father of the five Rothschild brothers did about the same time in the West. After he had established a branch in Calcutta, he sent out his son Elias to open branches in China and Japan. Elias, who spent many uncomfortable months of the year in a sailing-boat, founded offices in Canton, Hongkong and Shanghai, as well as agencies in Yokohama and Nagasaki. The branch in Canton was opened before Hongkong came into British possession and was then transferred to that colony. A few years after his father's death Elias left the firm, established the rival house of Elias David Sassoon and Company, and opened up branches in all the cities where there were offices of the parent company. The managers and clerks for all these 
branches were Jews brought out from India and Bagdad, who thus formed the pioneers and parents of the new community. They worshipped in synagogues built by their employers, who were famous for their piety and benevolence, and observed and perpetuated the Sephardic ritual and customs of their native land. But what impressed me most strangely was that the present generation had preserved the Arabic speech of their fathers, which they often used in conversation with one another, though few born in China could either read or write the language. When the Sassoon houses were first established, I was told, their books and correspondence were conducted in Judæo-Arabic written in Hebrew characters ; but now, of course, everything is carried on in English, though most members of the community can also speak fluent Chinese.

After tea we adjourned to the adjoining synagogue, which was built by Sir Jacob Sassoon, a son of the aforementioned Elias, and brother of the present Sir Edward. It is a handsome structure, surmounted in front by two turrets with a vague resemblance to pagodas without stories, whilst the interior is marked by the amplitude of space and sparseness of seating accommodation which I found characteristic of synagogues in the East. The prayers were read by Mr. Gubbay, for the community, which now numbers only a hundred souls, has neither Rabbi nor any other religious functionary; and after they were over, Mr. Ezra, in the name of the congregation, spoke a few words of cordial welcome to Rabbi Hirsch, who, in his response, expressed the hope that he would be able to extend his ministrations occasionally to Hongkong.

Mr. Gubbay then told us that he had an interesting scroll of the Law to show us, which had formerly been kept in the local Museum. It was said to have been the scroll that was used by the Jews of Kai-Feng-Fu, that derelict colony that is now but a memory, but it could not boast of such antiquity. It was borne from the:Ark to the Almemar, and taken out of the chased metal 
receptacle in which it is encased, for in the East, owing to the prevalent humidity, all scrolls of the Law, to prevent them becoming mouldy, are preserved in tightly closed cylindrical cases, which are artistically patterned. It was the scroll that had formerly belonged to the Jewish congregation of Nanking, which was now defunct; it was some inches longer than the modern scroll, and its caligraphy was distinguished by several peculiarities. We were also shown the collection of Hebrew religious books in an upper room, on the same floor as the ladies' gallery, and upon examining them I discovered a Hebrew translation of the New Testament. Mr. Gubbay and his friends were astonished; nobody knew how or by whom it had been smuggled into the sacred precincts, but I was assured that it had lain neglected and innocuous all the time, and that not a single member of the community had been seduced by its doctrines. But the book was now incontinently removed from its resting-place, to be presented to a local library or a Christian clergyman.

Besides the employees of the Sassoon houses and their families, Hongkong Jewry comprised several other persons, mostly merchants or brokers, some of whom had come from Europe or America. They had played their full part in the development of the colony, and some had displayed a benevolence by which their nonJewish neighbours benefited far more than their own co-religionists. Sir Ellis Kadoorie, the owner of the Hongkong Hotel, famous as the most comfortable caravanserai in the Far East, as well as of the Repulse Bay Hotel overlooking a faery-like inlet, had presented a school for the Chinese and another for the Hindus, besides the admirable Helena May Institute as a home for English girls ; ${ }^{1}$ whilst the late Hon. E. R. Belilios had

1 Sir Ellis Kadoorie, who died in 1922, left $£$ roo,000 to the British Government for the building of schools in Palestine or Mesopotamia, and the Government has decided to use half of this amount for the erection and maintenance of a Hebrew high school in Jerusalem, and the other half for the establishment of an Arab agricultural school at Tulkeram. He also left $€ \mathrm{120}, 000$ to the Anglo-Jewish Association for the benefit of education. 
founded a school for English girls. It was in the Helena May Institute that I addressed a public meeting, after having spoken to my fellow-Jews in their club. The Governor, Sir Reginald Stubbs, who presided, not only commended my appeal to the audience but, unlike many other Colonial officials who took the chair at my meetings, contributed something himself.

The Jews of Hongkong, although their nearest Jewish neighbours live in Shanghai, which is separated by a voyage of three days, and in Singapore, which is even two days farther still, do not live an altogether isolated life. For these are regarded as small distances in the Far East, and there is such a regular interchange of visits between the members of these communities that they are almost as familiar with one another as the Jews of Manchester with those of Liverpool, and I profited by the advance information I was thus able to gather. Only rarely are there unusual visitors. The strangest guests that the colony ever welcomed were the members of a travelling circus, who had arrived just a few weeks before. They were all Russian Jews, fugitives from the great Muscovite débâcle, who bore the style and title of "Bostock's Menagerie," and who travelled with the full equipment of animals, wild and domestic, freaks and acrobats. One member of the troupe wished his newly-born daughter to be named in the synagogue, and accordingly a special service was held early one Thursday morning, which was attended by the entire company as well as by a good proportion of the community. The happy mother, a bare-back rider, was present with her babe, and the clown was also there, a man of serious mien, who had known many sorrows. The father was called to the Law, and the infant heroine was given the name of Elisheba. After the ceremony there was a festive gathering in the Club, at which the health of little Elisheba was drunk from many clinking glasses. From Hongkong the company of wandering Jews sailed to Manila, on their way to America. 
Before the war the colony used to be visited periodically by Meshullochim, those pious envoys who were sent to collect contributions for the maintenance of synagogues, houses of study, or hospitals. They used to come from Palestine and from Mesopotamia, stopping first at Bombay, then at Singapore, Hongkong and Shanghai, and returning by the same route. Those who came from the Holy Land created the impression of good and learned men ; they carried letters of introduction from the Rabbis of Jerusalem, and had special books in which the donors wrote their names and donations. But those who came from Bagdad, I was told, were of inferior character: merely Schnorrer, of whom the community was only too anxious to get rid. The Meshulloch generally stayed a few months in each place, acting as Hebrew teacher and synagogue reader, and making himself comfortable in the house of his deferential host. But as the Hongkong community began to grow doubtful of the amount of their gifts that reached their destination, they requested that no further envoy should be sent and promised that they would remit their annual contributions direct-an undertaking that has been faithfully kept on both sides for the last twelve years. 


\section{CHAPTER XVIII}

\section{SHANGHAI}

I

$\mathrm{N}$ board the Shinyo Maru, on which I sailed from Hongkong to Shanghai, two of my table-companions were young Americans, both the sons of Russian parents. One was a native of the States, who had graduated at Cornell University and was in the Consular service, and he was now proceeding to Western China to open up two new Consulates on the very border of the Mongolian Desert. I asked him whether there was any truth in the stories about American college students who worked in their holidays as waiters or tram-conductors so as to maintain themselves, and he replied that this was so. He had himself been employed as a waiter in a boarding-house not only in the holidays but also in term-time, otherwise he would never have been able to complete his university education. The other young man was a native of Russia, who had served the previous year with the American Expeditionary Force in Siberia, and he was now bound for some remote spot in the vicinity of Lake Baikal, where he scented the potentialities of prosperous trade. The two men, who had never met before, often compared notes on deck as the ship ploughed its way through the rough sea, and I joined them occasionally and discussed the developments in Palestine. They were both of the calibre requisite for the pioneers of a Jewish Homelandyoung, robust, intelligent, keen - and they hoped that they would some day be able to play a part there. Meanwhile, one was going to extend the American Consular service 
to the edge of the Mongolian Desert (and pored diligently over a Chinese primer), whilst the other was going to seek his fortune in the forbidding region of Lake Baikal.

The fourth member of our tahle quartette was a retired captain of the British mercantile marine, who had been in command fifteen years ago of the very ship on which I had sailed to Australia. He seemed to have an unusual partiality for Jewish company and told us of an incident that testified thereto. Some years before the war he was captain of a vessel that went on holiday cruises from England to Norway, and on one occasion there was a Jewish party on board which he noticed was being given the cold shoulder by the other passengers. He therefore made himself particularly amiable to the Jewish travellers, dancing with the ladies and drinking with the gentlemen, until they became equally popular with everybody else. The gentleman in charge of the Jewish party was the late Sir Joseph Lyons, who, anxious to show his gratitude, asked the captain to call on him in London if he should ever need his services. Some years later the captain arrived in the metropolis one evening at a time when all London hotels were packed and his quest for a room became desperate. Suddenly he bethought himself of the promise received on the Norwegian cruise, hastened in a taxicab to the Trocadero, received a genial welcome from Sir Joseph, and at once had a suite of private rooms with attendance in a fashionable quarter placed at his disposal. At the end of his stay he asked for the bill and was then told that there was nothing to pay. "You are a grateful people," was the captain's concluding comment:

With the exchange of anecdotes and experiences the three days' voyage quickly sped. The ship weighed anchor at Woosung, and as I sailed on a steam launch along the muddy Whangpoo, the last affluent of the Yangtze-kiang, which was enlivened by numerous junks with terrible dragon heads, I studied the English newspapers of Shanghai which were sold on deck, and read 
I24 THE JOURNAL OF A JEWISH TRAVELLER

friendly accounts of my mission. I was welcomed at the wharf by a group of friends headed by Mr. N. E. B. Ezra, the honorary secretary of the local Zionist Association, whose name and zealous activity had long been familiar to me. There was also a young Russian Jew, Mr. Jacob L. Friend, who had once lived in Warsaw and contributed to its Hebrew press, and whom the war had transplanted after various tribulations to Shanghai. And there was a Yiddish actor too, a member of a company that gave regular performances in this exotic environment. From the moment of my landing on a bleak and drizzly Friday morning I realized that the Jewish community was almost as international in its composition as the city in general. The core and the dominating element was Sephardic, derived like Hongkong Jewry from India and Mesopotamia, for the first Jew to set foot here, about I850, was also the enterprising Elias David Sassoon ; but there were also many Jews from Western Europe and America. They formed together the organized congregation, with synagogues, school and benevolent society, comprising about 500 souls, most of them engaged in commerce. But since the war there had grown up a supplementary community of Russian Jews, estimated to number about rooo in all, who had fled or drifted hither from various parts of Russia and found a living for the most part as small tradesfolk or artisans.

I was rather surprised to find that in this cosmopolitan city, this "Paris of the East," where so much feverish energy was spent upon the amassing of wealth and the pursuit of pleasure, there was a veritable stronghold of uncompromising orthodox Judaism. The stronghold was rather sparsely manned, it is true, and those who watched over it might truthfully be described as members of the "Old Guard," for they belonged mostly to the older generation, as familiar with quotations from the Talmud as with those of the Stock Exchange. I passed 
my Sabbath eve and Sabbath morn in the very odour of sanctity, in a milieu of strict observance and cheerful ceremonialism. I attended the evening service in the synagogue in the Whangpoo Road, a large upper room over the school, where there was a fair attendance, and at the conclusion of the service I was conducted to a neighbouring room where the Russian Jews worshipped, and where Yigdal was sung in the same familiar strains as in an East End Chevra.

I was invited home by Mr. Sassoon J. Solomon, a pious and learned man, who has a remarkable library of Hebrew lore, and who spends his days on the books of the Sassoons and his nights on the books of the Cabbala. The Sabbath table presented the traditional genial appearance, except that the "loaves" were like large, flat, blistered pancakes, though tasting unmistakably like bread. I was told that the Sabbath bread of this shape was baked in the homes of all orthodox Eastern Jews, and I afterwards came across it in Singapore, Rangoon and Calcutta. Most of the dishes were of the Bagdad or Levantine school of cookery, which is faithfully preserved in most of the Sephardic households throughout the East, and there was an unusual abundance of fruit, with divers Oriental species such as the pawpaw and the pumelo. There was also an abundance of benedictions, both before and after the meal. But what interested me above all were two of the guests. One was a Russian Jew of middle age, who only opened his lips to pray. He had lost wife and children in the flight through Siberia, and was employed here as a Hebrew teacher.

The other was a much stranger personality: he was a man of pronounced Mongolian physiognomy, with high cheek-bones, slit-like eyes, yellowish complexion and a black beard and moustache of loose, lank hair. He looked a man of forty-five, but was actually sixty-seven. He went by the name of Joseph Wong, and a strange romance surrounded him. When he first arrived in Shanghai, four years before, he spoke a dialect of Chinese 


\section{I26 THE JOURNAL OF A JEWISH TRAVELLER}

Turkestan which nobody could understand, but gradually he picked up Chinese and told his story. He said that he was a Jew from Kashgar, where there was a small Jewish community that used to be visited once a year by a Rabbi from Southern Russia. He had dwelt there with his aged mother, and they had had many flocks and herds, and lived there in peace and plenty. But through the disturbance of the war they had to wander forth, and they travelled for months through strange and desert places until his mother, who was over ninety, yet strong for her age, began to grow weak and sickly, and he had to carry her. On the way they were robbed of all the possessions they had with them, and then they heard that there were Jews living in Kai-Feng-Fu. So he left his mother with some people in a friendly town, and went in search of his brethren; but when he came to KaiFeng-Fu, he learned that no more Jews were there, but some had gone to Shanghai. He therefore returned to his mother, only to find that she had meanwhile died, and then he came to Shanghai. He knew no Hebrew, I was told, when he first arrived, but he had since learned a little. He was scrupulously observant of religious law, and a regular and devout attendant at synagogue. He had been steadily pursued for the last two years by Christian missionaries who saw in him a promising quarry, but he had steadfastly rejected all baits and repelled all attacks. I gleaned his story through the clever interpretation of one of Mr. Solomon's daughters, and when he, in turn, learned of the nature of my mission, his simple face lit up with a look of awe and he begged to be allowed to attend one of my meetings. 1

As for the Jews of Kai-Feng-Fu, Mr. Solomon, who had

1 Alas, for human credulity I Joseph Wong, of whose Jewishness and piety there was never any doubt, and who was employed as beadle of one of the synagogues, was afterwards discovered (as I was recently informed by Rabbi W. Hirsch, on his way through London from Shanghai to Pretoria) to be a Mohammedan, who was engaged in obtaining contributions from the adherents of Islam in China for the alleged restoration of some Moslem temple. Thus is another Eastern romance shattered. 
taken an active part many years ago in investigating their conditions and in bringing eight to Shanghai, told me that there were now only two left. They were employed in Jewish business houses, but they were too thoroughly assimilated, mentally as well as physically, to be able to understand anything of the Jewish faith, and it was only a question of time before these two last survivals of the ancient colony would become extinct. There was, indeed, a report that in the neighbourhood of Nanking there were some thousands of Chinese with Jewish facial traits, though without Jewish customs; but no attempt had been made to discover whether they were of Jewish origin.

The following morning I again attended worship at the same synagogue. The service began at seven o'clock, the hour at which it is begun in all synagogues throughout the East, unless it starts even earlier in the summer. I was called up to the Law, and as I advanced towards the Almemar ${ }^{1}$ there were cries of "Kabod (honour)!" from the congregation, who, when I presently descended, greeted me with the words "Chazak u-baruch (be strong and blessed)." I noticed, when others were subsequently called up, that their respective relatives remained standing whilst the particular section of the Law was being read, and upon the honoured kinsman returning to his seat he offered them a fringe of his talith, ${ }^{2}$ which they devoutly kissed. There was no prayer for any " royal family " or other ruling authority, as we were in the International Settlement, and the service concluded at a quarter to nine, just when the Ashkenazic service was beginning. On leaving the building, I saw a couple of rickshaws waiting outside, and I was told that the moot question whether the use of these vehicles was permissible on the Sabbath would have to be solved by the new Rabbi. For there were some orthodox Jews who, living at a distance from the synagogue, were carried thither in a rickshaw, the Chinese doorkeeper paying the fare, whilst

1 Reader's platform. $\quad$ Praying-shawl. 
after the return journey the fare was paid by a domestic. Again Mr. Solomon invited me home, and after Kiddush ${ }^{1}$ I was struck by the fact that he uttered a benediction over a glass of myrtles, a rite that I found to be in vogue in the communities of Eastern Jewry. The breakfast was an appetizing collation of many courses, though mostly cold. It was my host's lunch, to be followed five hours later by dinner, for he piously observed the custom of eating only three meals from the eve until the close of the Sabbath. But he tolerantly conceded to the younger generation the option of conforming to the general dietary time-table. ${ }^{2}$

\section{3}

I had not been in the city more than an hour or two before I heard many tales of the economic depression that had swooped down upon the Far East, and was pitifully reproached for not having come twelve months earlier. Then trade was booming, the tael was worth nine shillings, and everybody was making money so rapidly and profusely that I should have rendered a public service by removing some of it. Now there was a general slump, the tael was worth less than half of what it fetched before, the staple of the local markets-cotton-had depreciated, and many had lost heavily by speculation. To all these plaints and reproaches I replied that it would have been imprudent for me to come before the San Remo decision, for I could not then have " delivered the goods" and I could hardly have demanded payment for Zukunftsmusik. We must simply make the most of the situation, I urged.

My first appeal was made in the house of Mr. Edward I. Ezra, a local magnate, who acted as president of the Zionist Association. Through the columns of the local press he invited all members of the community to a reception at his house to welcome Rabbi Hirsch and myself, and nearly 500 people came. It was a house of palatial proportions and baronial magnificence, recalling

1 Sanctification.

$2 \mathrm{Mr}$. Solomon died in 1922. 
some of the splendours of the Arabian Nights. Situated in over sixty acres of beautiful grounds, it was guarded by a dozen Annamite policemen in picturesque blue uniforms with mushroorn-like hats. The gardens, each one lovelier than the other, were looked after by sixteen gardeners: they were not only rich in all species of exotic plants and rare and fragrant blooms, but adorned and diversified by a Chinese, Japanese and Italian summer-house, a tea-house, a boating-lake, a bowlinggreen and a tennis-lawn! The reception was in the ballroom, a large and ornate chamber with rose-coloured wall-paper and brocaded curtains and gilded chairs. The proceedings were opened by a jazz band, to whose cacophonous summons a hundred pairs of twitching feet readily responded, and the pressure of the revolving dancers gradually forced a migration of the throng into an adjoining chamber, where refreshments were served on a lavish scale by a battalion of Chinese waiters clad in speckless white. At last, when the merriment was at its height, Mr. Ezra advanced to the orchestral dais, the music stopped and the speeches began. Our host paid an eloquent tribute to Rabbi Hirsch for his courage and zeal in venturing out to such a remote outpost of Eastern Jewry and congratulated the community upon at last securing a spiritual guide. The Rabbi acknowledged the communal welcome with touching sincerity, and pleaded for the co-operation of the older generation if he were to secure the attachment of the younger. Then our host introduced myself, and in my reply I contrasted the gaiety around us with the widespread distress in Eastern Europe which the restoration of a Jewish Palestine was designed and destined to alleviate. I also announced, amid great applause, that Mr. Ezra had promised the first donation- $f$ Iooo.

As I moved about and chatted with the guests, I met many men of marked diversity of origin, type and activity. There were prosperous Bagdadi merchants and brokers, Russian Jews who controlled the local cotton $\mathbf{x}$ 
markets, a French Jew who was a member of the French Municipal Council, American Jews who had businesses with ramifications from New York to Tientsin, a Hungarian Jewish doctor who had been a prisoner-of-war in Siberia and resolved not to return to the White Terror of Budapest, and an Italian Jew who had rendered distinguished services in Tripoli during the war and received an important decoration. I also met a young poet, with a gift for lyrical and satirical verse ; a young Russian Jew, the son of a Rabbi, who was in the service of the Chinese Government and always wore Chinese garb at home; and a Jew from Nagasaki, who told me that there were now only four Jews left in that city, that the synagogue had been closed for months, and that he was anxious to have the scrolls of the Law transferred to Shanghai. As for our host, he was a host in himself, for he owned the three leading hotels of the city and one in Peking, a daily newspaper, and the substantial block of the Edward Ezra Buildings, flanked by Ezra Road, in which he had a sumptuous suite of offices. ${ }^{1}$ But among all that varied throng, even among those who sang the praises most loudly of China's art and civilization and untapped and immeasurable commercial resources, I did not find a single person who, imitating the formula current in Western Jewry, described himself as a Chinaman of the Jewish faith. Not even the only member of the community who was married to a Chinese wife and lavished his wealth upon Chinese schools and orphans would have adopted that designation. On the other hand, the Chinese had been drafted into the service of the Jewish cause, for a Celestial firm had printed various Hebrew books with immaculate accuracy for the use of Jewish communities in Siberia.

A few days later, in one of Mr. Ezra's hotels, there was a public meeting. It was well attended and graced by the presence of the British Consul-General, Sir Everard Fraser, and of Judge Lobingier, of the United States

1 Mr. Edward I. Ezra died in 1922. 
Supreme Court, who both earnestly supported my appeal for the Palestine Restoration Fund. There was at first a shyness to subscribe on the spot, and a desire was expressed for private canvassing, but I insisted upon the method that had succeeded in the Antipodes, with the result that pledges were given for $£ 7000$, including three further donations of $£ 1000$ each. ${ }^{1}$ But as many were not present, I had to expend much time and energy on the following days in visiting offices and countinghouses, in the course of which quests I made the interesting discovery that the proprietor of the largest number of public rickshaws that plied for hire in the city was a Russian Jew. On these delicate expeditions, I was often accompanied by Mr. N. E. B. Ezra, who, in the intervals of his business, edited the local Zionist organ, Israel's Messenger, with apostolic zeal and combative pen; and the result was the addition of another $£ I 200$.

\section{4}

After an interval of a month, spent in Japan and other parts of China, I was back again in Shanghai. I stayed at the house of Mr. Ezra Shahmoon, a young merchant who had fled during the war from the Turkish oppression in Bagdad and whom fortune had greatly favoured since his sojourn in Shanghai and left unspoiled. On the Sabbath eve, one of his Chinese "boys" asked me, "Chin-chin joss?" and as I was at first mystified by the query, he repeated it with more vigorous intonation until it dawned upon me that he wished to know whether I was going to pray in the synagogue. It was strange to hear the Chinese word for " idol " used in connection with a Jewish house of worship. The place we visited was a handsome shrine in the residential quarter built, quite recently, by the late Sir Jacob Sassoon as a memorial to his wife. It was a large edifice, standing in its own spacious grounds, with the interior fittings mostly in grey

1 These were given by Messrs. D. Sassoon \& Co., Messrs. Shahmoon Bros. and Mr. T. Toledano. 
I32 THE JOURNAL OF A JEWISH TRAVELLER

marble and oak. It was designied so as to seat a few hundred, but I counted only twenty, including a lady, so that it had evidently not yet become a popular institution. The committee, however, had lavished much thought upon its construction, anxious that it should conform to traditional requirements. Upon the distempered wall of the vestibule there was a bare patch, as a symbol of the destruction of the Temple, and in the grounds there had been dug a deep, round well, which was intended to take the place of the stream into which orthodox Jews are wont to cast their sins on New Year's Day with the aid of a special invocation. As my eye measured the cubic capacity of the well, I could not help expressing a doubt whether it could accommodate all the iniquities of the large and absent congregation.

One attempt had, indeed, been made to provide the community with a popular institution, namely, with a club. It was the scheme of Mr. E. S. Kadoorie, who displayed imagination and courage in designing a Jewish Club such as would have surpassed in comfort and elegance any other club in Shanghai. It aroused much enthusiasm at first. The plans were drawn upon a grandiose scale, comprising large public rooms, a wonderful verandah, many bedrooms, two separate kitchens (for meat and milk foods) and a dozen baths. A great part had already been built when a fire broke out, causing extensive damage ; and the water that extinguished the fire seemed also to have quenched the ardour of the community, for they all withdrew their support, leaving the bold founder to devise some other purpose for the building.

The only secular institution, curiously enough, seemed to be the Yiddish theatre. The company of Yiddish actors had been driven across the vast steppes of Russia by the war to seek a livelihood in this Chinese city, where they performed once a week before an admiring throng of their countrymen. They were waiting daily and anxiously for tidings of the recovery of Russia from the 


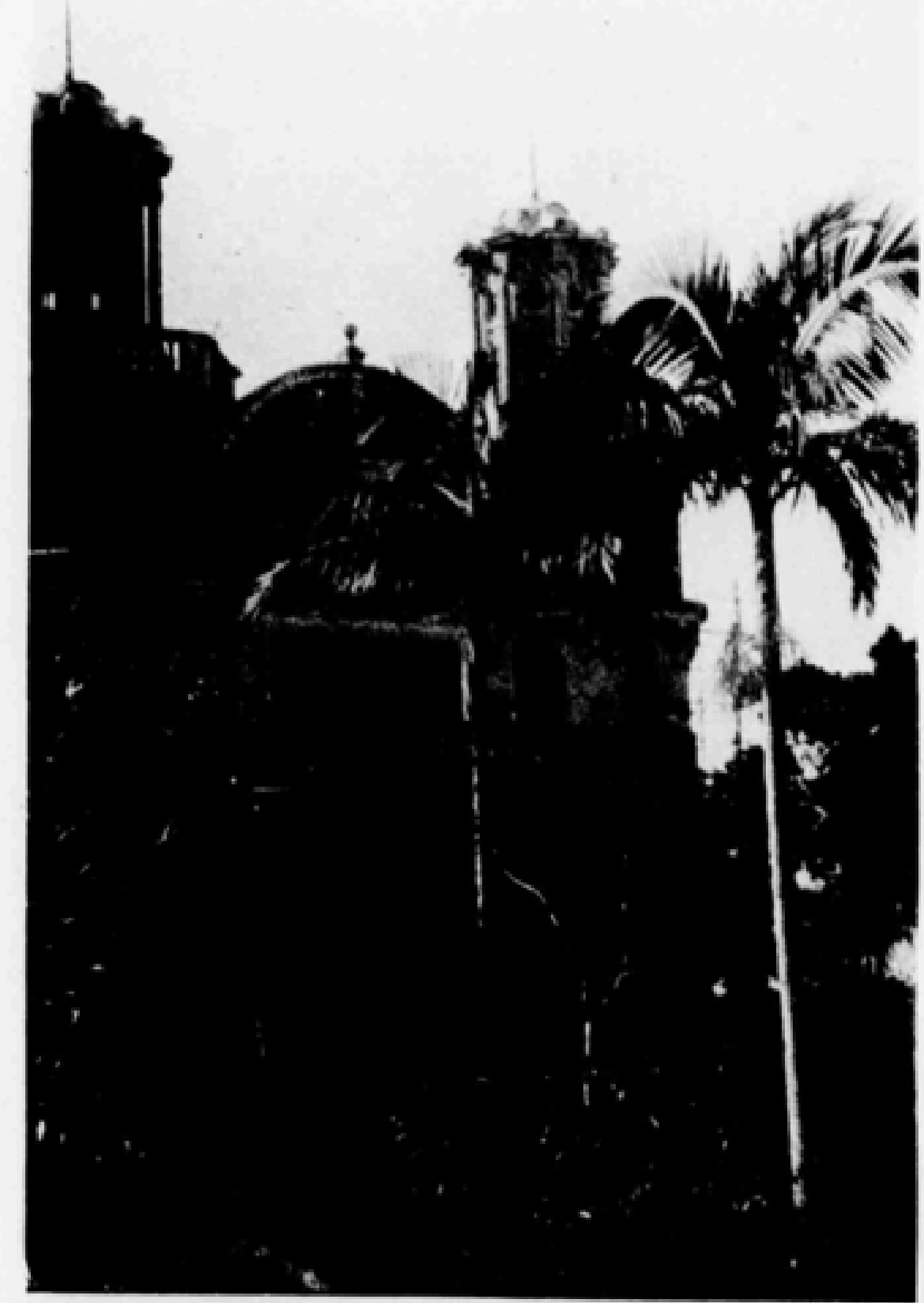

SYNAGOGUE AT HONGKONE:

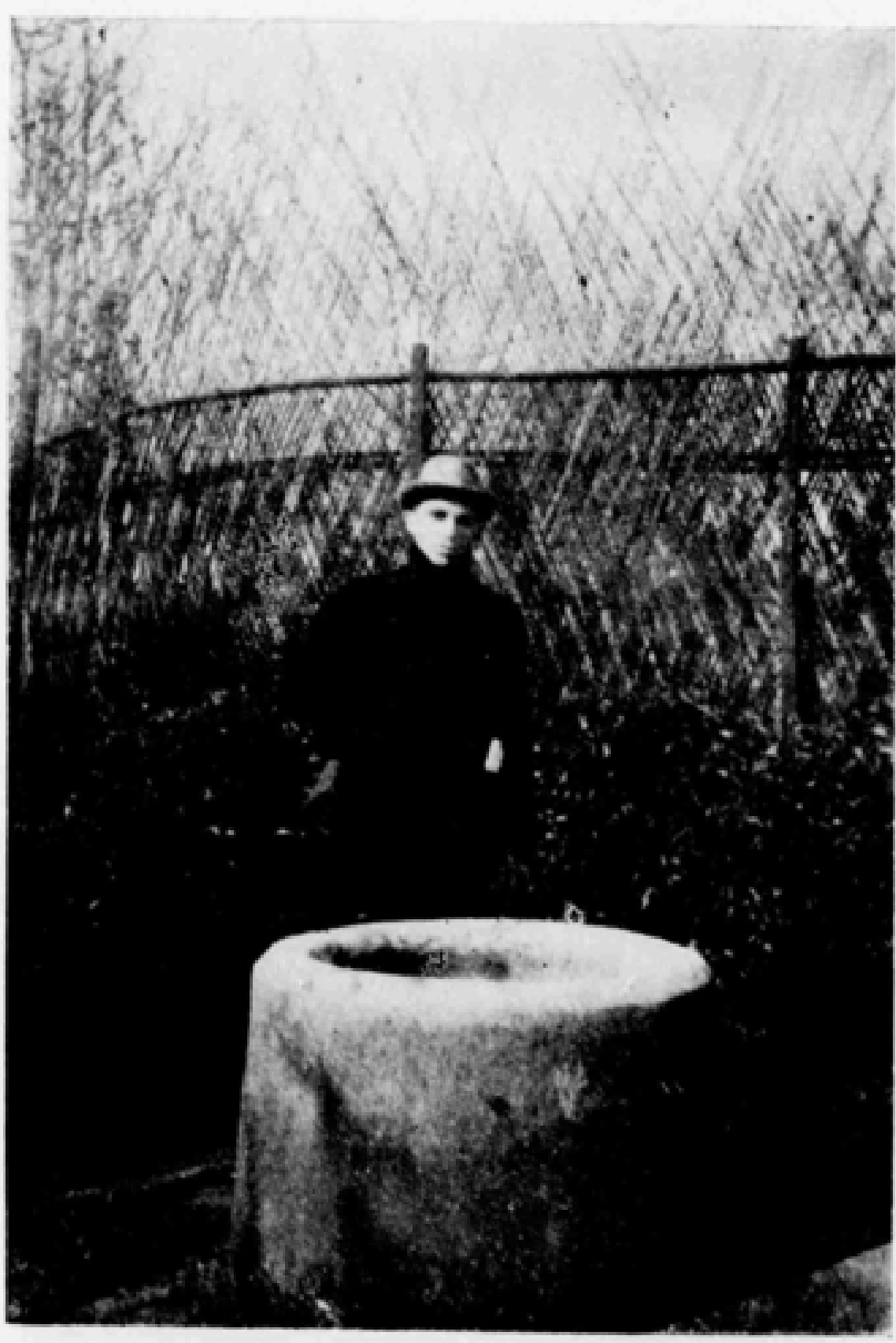

"TASHLICH" WELL, SHANGHAI 


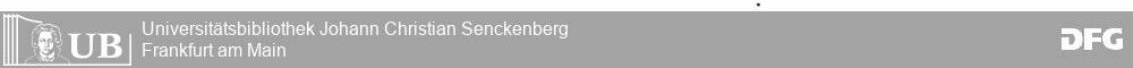


Bolshevik nightmare, and hesitated to make any lasting arrangements in what they regarded as a temporary asylum. They played in the large hall of the Y.M.C.A., where I witnessed a production of The Sacrifice of Isaac, the opera by Abraham Goldfaden. The scenery was scanty, consisting for the most part of a Chinese temple and gardens, and of a tall bare tree which threatened to collapse at the merest touch. The middle of the stage was obscured by a conspicuous dome which concealed the prompter, whose loud whispers were distracting. Abraham presented a striking patriarchal figure, with his venerable white beard and flowing white robe, but Sarah appeared uncommonly youthful and robust for a matron of ninety. The part of Isaac was taken by a rather portly lady with ample bosom, over whom Sarah sang a most touching lullaby that moved all hearts until "he" fell asleep, and my sympathy went out to the patriarch as he strained every muscle in lifting his only child and carrying " him " to the altar. The clown of the piece was Ishmael, a gross egoist, who indulged in rough buffoonery in wordy bouts with Eliezer as to who would inherit Abraham's wealth. Upon the appearance of the three angels, all dressed in black, he brought them dainty dishes which he eloquently recommended and ravenously gobbled up himself. Only in the presence of Abraham was he at all subdued and respectful. He shirked the carrying of a bundle of firewood which was required for the altar, and put it on the back of an invisible donkey, which was supposed to be in the wings and which he pulled by a rope in the intervals of a coaxing and jesting speech. On the way to Mount Moriah, the patriarch was intercepted by a messenger in black, Satan, who wished to thwart him-but in vain. Abraham made ready for the sacrifice when an angela young man with white paper wings-suddenly stayed his hand, and Eliezer appeared solemnly moving along with a white paper ram between his fingers. The final scene showed the family happily reunited and closed upon the joyous strains of a thanksgiving song. 
I34 THE JOURNAL OF A JEWISH TRAVELLER

After the fall of the curtain Eliezer, on behalf of the management, returned thanks to the "honoured public" for their attendance, and invited them to come again next week to see The Power of Love. But not all my love for the Yiddish drama was powerful enough to keep me longer in Shanghai, as I had to enter upon the next stage of my journey. 


\section{CHAPTER XIX}

JAPAN

I

7 HE first sight that struck me as I entered the saloon of the steamer that was to take me from Shanghai to Kobe was a couple of Japanese

1 gentlemen, one in European dress and the other in a kimono, bending down towards one another, with their backs almost at right angles to their legs, and their heads just alongside of each other. They glanced at one another solemnly through the corner of their eyes, raised their backs slightly, then slowly lowered them, each apparently trying to bend lower than the other. Again they glanced at one another, raised their backs a little, and gradually lowered them, trying once more to outdo each other in their downward progression. Silently and stolidly they went through the same stooping movements with mechanical jerks, six or seven times, as though executing some religious rite. Presently another Japanese gentleman indulged in a similar performance with a lady compatriot in native dress, and I began to revise my opinion of its significance, when a loquacious young Chinaman, who had learned English in Hongkong, explained to me that it was the Japanese mode of courteous salutation, the less important of the two persons always stooping an inch or two lower than the other. This mode of obeisance could obviously be practised more successfully before a meal than after, but fortunately it was not expected from a foreigner at any time. 
I was the only European on board the little Japanese vessel, which had a full complement of Japanese and Chinese passengers, but both the captain and the stewards spoke English tolerably well. My cabin was shared by two young Japanese, who lay wrapped in their kimonos in their berths, one above the other, the greater part of the day, carrying on what may have been a philosophic duologue and filling the air with the nauseating fumes of amber cigarettes. The voyage was rough and cold, but, fortunately, brief, for on the third day we reached Moji, at the entrance to the Inland Sea. I had first intended visiting Nagasaki to see the pretty little synagogue of which I had heard, ${ }^{1}$ but as its Jewish community had dwindled to four or five souls and the journey thither from Moji and back would have taken nearly two days, I decided that, with the limited time at my disposal, it would be best to remain on board and make straight for Kobe. The famed beauty of the Inland Sea was veiled by a grey sky and the melancholy of winter, and the first romantic view of Kobe that I had fondly pictured to myself was eclipsed by the sombre reality of gaunt factory-chimneys and a deluge of rain that would have quenched the ardour even of the most sentimental traveller. The only novel feature attaching to my landing was supplied by the passenger-list affixed to the notice-board, for there my name stood out alone in Latin characters, surrounded by festoons of hieroglyphics denoting the patronymics of the Celestial voyagers. I was welcomed by Mr. Walter Buechler (son of Dr. Adolf Buechler, the Principal of Jews' College), who was armed with a big yellow oilskin umbrella, and soon we were trundled along muddy roads to the hotel in closed rickshaws furnished with oilskin windows, which had a fleeting resemblance to the hansoms of bygone days.

There was no organized Jewish community in Kobe, although there were said to be about 200 Jews in the

1 This synagogue and the land on which it was built were sold by auction in 1924 for $£ 220$, to be converted to secular use. 
city. Half of them were from England, America and Bagdad, having businesses of their own or representing foreign firms; the other half were fugitives from Russia, waiting either to return after the Bolshevik chaos was over or to cross the Pacific and seek their fortunes in America. The recognized head of the Russian colony was a Mr. Yabroff, who had succeeded in bringing over the family samovar, which did as good service in its new home as ever it had done in its old. Within his house I almost forgot that I was in Japan, for the languages spoken were English, Russian and Yiddish, and the dishes and drinks were all reminiscent of the Ghetto. There I met a rubicund, grey-haired teacher of music, enjoying the courtesy title of professor, who made quite a fair livelihood by giving lessons and concerts, and who seemed none the worse for his exile. Although uncertain of the future, the Russians were resolved to make the most of the present, for they-Jews and non-Jews combined-had created a little club for social intercourse and entertainment, which had acquired immediate favour. It was situated in the upper part of a private house, and consisted of one long room, at the farther end of which was a little stage curtained off. There I spent my first evening after dining with some friends (two brothers named Goldman, of London), who told me how charmed they were with the scenery of the land and how annoyed by the xenophobia of its people. Two Russian one-act comedies were performed, of which a brief explanation in English was previously given by the producer for the benefit of those who did not understand the language. They each presented a case of illicit love-reflecting the moral anarchy precipitated by the Russian political upheaval-and they were afterwards followed by some singing and fancy dancing. In the middle of the entertainment there was a sudden howl of the wind, the house shook, and the electric light went out for a moment or two. "It's only a typhoon in the neighbourhood," remarked my neighbour. "Don't be alarmed." The 
lights went up again, and the artists concluded an eccentric dance amid frenzied applause.

It was impossible to convene a meeting at short notice in such a small and unorganized community, so I decided first to go to Yokohama for a few days and, upon my return, to address a meeting which could meanwhile be arranged. But before leaving for Yokohama I spent a couple of days in visiting various Jews in their offices and trying to obtain donations for the Palestine Fund. The response was at first feeble and fitful, as was perhaps inevitable in the frigid zone in which Judaism was here situated. "Palestine is a rather long way off from here," said one merchant who had long been domiciled in Kobe. "Yes," I replied, " and I have come all that long way to enable you to do your duty." Each man upon whom I called was kind enough to give me the names and addresses of two or three others, while imploring me not to betray the source of my information, and thus the list slowly improved. Two men whom I visited brought home to me the tragic consequences of the isolation of the little Jewish colony. One was married to a Japanese wife, but he pretended to bear no relationship to his slant-eyed Eurasian son, who remained mute and timid throughout the conversation, and whose identity was whispered to me by the friend who accompanied me. He even pretended that he was only on a visit to Kobe and that his home was in London; but, having received a little proof of his generosity, I was unwilling to impugn his veracity. The other case was that of a man who was himself the offspring of an English Jew and a Japanese mother. His name was undisguisedly Jewish, but his features were unmistakably Japanese and his views were suspiciously anti-Semitic. "I'm no Jew," he said, with a foreign accent, "though my father was one. I'm a Japanese and a freethinker, and I don't agree with your mission. Religion is a curse, and if you were raising money to fight it, I should be glad to help you." Evidently his free-thought was not liberal thought. A few 
months later I met his father in Burmah; he looked a typical West End Jew, though he had left London over thirty years ago. There were only a few cases of such Judeo-Japanese marriages, the social ostracism that they involved serving as sufficient deterrent to their increase.

On the morning after my arrival the hotel clerk told me that the chief of the foreign section of the police would call upon me in the afternoon. I asked him how the police knew of me, to which he candidly replied that he always reported the arrival of foreigners, especiallywith a grin-if they appeared to be persons of importance. The functionary who called was a dapper little gentleman in black frock-coat, who bowed deferentially and made himself at home in my room. He opened the conversation by saying that he was a student of social conditions in foreign countries, and was, therefore, anxious to learn from me of the latest developments in England; but when I pointed out that he could always get the information he sought from the press or from the Japanese Consulate in London, he admitted that he was curious about my visit. He spoke English slowly but correctly, and I thought that I should have no difficulty in explaining to him the nature and purpose of my mission; but his ignorance of things Jewish was abysmal, and it was not until after an hour's penetrating cross-examination that he at last expressed himself contented. I had to give him quite a lecture upon the Jewish diaspora, Jewish nationalism, Jewish sufferings and aspirations, Great Britain, Palestine and the Balfour Declaration, and after I had inwardly congratulated myself upon enlightening him, he innocently asked: "And where is this Palestine, in England ?" I was speechless with amazement.

"Oh, I see," he corrected himself, " it is in Poland."

I took an atlas and showed him the exact position of the Holy Land. He gazed at it like a little Columbus. Having convinced himself that Zionism was not Bolshevism - for that was his underlying fear-he made me describe the whole of my itinerary from the day I left 
London, as well as all the details of my stay in Japan. He even inquired by what train I should leave for Yokohama, in what hotel and how long I would stay there, what other towns I would visit, when I would return, and whither I would then go. He wrote down the hour of the train by which I was to leave Kobe that evening, but he thoughtlessly left the note behind him-and I thoughtfully tore it into tiny tatters.

\section{2}

After an all-night journey in a comfortable though rather smelly sleeping-car, I reached Yokohama early the following morning. The berths were ranged in a double tier along both sides of a long compartment, a gangway running through the middle. Both men and women slept in the same compartment, but the berths were curtained off so completely that it was impossible to detect the sex of one's neighbour either above, below or opposite. A neatly uniformed train " boy " provided one with a coat-hanger at night, and brushed one's boots and clothes in the morning. As we approached the city there was snow on the ground, and I was rudely reminded that my visions of cherry-blossom and chrysanthemums would not be realized unless I prolonged my stay for a few months.

The Jewish community of Yokohama was somewhat larger than that of Kobe, comprising about 300 persons altogether. Less than half constituted the resident element, commercial folk of varied degree, hailing from England and America, from the Levant and Bagdad, conducting business with all parts of the world. This element dated back nearly fifty years, the oldest member, an English Jew, upon whom I called the first day, having a Japanese wife, with a son whose maternal origin was unmistakably evident. The larger portion of the community consisted of refugees from Russia, whose number in the previous year had been much greater. The refugees had all come across from Vladivostok, between 
which and Tsuruga there were weekly sailings, and the poorer among them had been looked after by' an agent of the Joint Distribution Committee of America, which had opened a Jewish Immigrants' Hostel in a large house in Main Street. The Hostel comprised not only diningroom, dormitories and reading-room, but also a small synagogue equipped with an Ark of the Law. By the end of I920 some hundreds of refugees had already been shipped to America, and as it was thought that the Jews in Siberia had now become accustomed to the prevalent state of alarm and unrest, the help of the American Committee was gradually reduced, its agent was recalled home, and a small committee of the richer exiles assumed the care of their poorer brethren. Those who had salvaged anything of their property had opened up trade with Siberia and China; the others lived on the charity of their fellows, and were provided in turn with passages to San Francisco. I often met some of them in Main Street, where a little kosher restaurant had been opened ; and I saw them, too, in the lounge of the Grand Hotel, where, as the little Japanese maids shuffled about daintily with lacquer tea-trays, they sat gazing through the vast expanse of window at the ships of all nations that came into the harbour, and listening to the orchestra that incliuded some of their own co-religionists.

It was Friday when I arrived, and as I wished to address a meeting on Sunday afternoon, and no preparations had yet been made, there was no time to lose. The meeting could not take place without the express permission of the local authorities, so I at once wrote a letter to the Chief of Police, informing him of the purpose of the proposed gathering, which was to take place in the Immigrants' Hostel ; and thereupon I called upon the British Consul, who readily agreed to send a note to the police in support of my application. Anticipating that permission could not possibly be refused, I went to the offices of the two local English papers, the Japan Gazette and the Japan Advertiser, and handed the editors an announcement of 


\section{I42 THE JOURNAL OF A JEWISH TRAVELLER}

the forthcoming meeting, to which they gave prominence in their next issue.

Early next morning, before I had completed my toilet, there was a rap at my door, followed by the entrance of a plain-clothes policeman with a polite invitation to call upon his Chief at eleven o'clock. I went to the policestation in the company of Mr. Solomon Goldberg (a brother of the well-known Zionists, Messrs. Isaac and Boris Goldberg), who told me that a policeman had been at the hostel at eight o'clock that morning and crossexamined the superintendent as to the purport of the meeting announced. We were cordially received by the Chief of the Police, a thick-set individual in goldbraided uniform, wearing spectacles that softened his bureaucratic sternness. He was just as much at sea about the meaning of Zionism as his colleague in Kobe, but with the aid of an interpreter and a secretary who deferentially acted as intermediaries I succeeded in making him grasp the nature of my mission in half the time. During our interview, which took place in a chilly room, two portable braziers were brought in so that we could warm our hands, and the fear seized me that I was to be subjected to a prolonged catechism. In a room above there was a great deal of banging, beating, firing and shouting, which made me think that political prisoners were being tortured there. The Police Chief seemed to be interested just as much in my personal movements as in the Zionist movement, and the secretary made careful note of all my replies. At length, after I had satisfied him that Zionism had nothing to do either with Socialism or Bolshevism-Socialism being feared as much as Bolshevism, and violently suppressed by the Government-and also that I had no intention of floating a loan in Japan, he declared that he would permit the meeting, but would send two representatives to hear me. I replied that he could pay me no greater honour unless he would attend himself, an invitation that he smilingly declined. Outside the building Mr. Goldberg explained 
that the noise on the upper floor was due to the training of the police in revolver practice, ju-jitsu and other arts of self-defence.

Fate dealt rather unkindly with the meeting, from which I had expected so much. It rained heavily that afternoon, so that none but hardy spirits would venture forth. Assembled in the Hostel synagogue, which was festively decorated with Zionist banners, were about fifty persons, including two policemen, two Japanese journalists and a number of Russian refugees, while the rest consisted of English-speaking Jews and a few Christians. I asked the oldest Anglo-Jewish resident, who was present, to take the chair, but he frankly told me that he came only as " the figure-head of the community" -a modest self-appraisement-out of compliment to myself, but did not intend identifying himself with my mission. Another gentleman, therefore, introduced me, and I had scarcely begun my address when one of the journalists took a flashlight photograph of me-perhaps at the suggestion of the police. I spoke rather briefly, first in English and then in Yiddish; but as soon as I began my appeal and looked significantly in the direction of the oldest Anglo-Jewish resident, the latter rose to his full height, with the eyes of the whole assembly upon him, and stalked haughtily out of the building into the street.

But despite this discouraging prelude, the gathering yielded $£ 200$, which I subsequently succeeded, by dint of private calls, in increasing by half as much again. Several of those present were inmates of the Hostel, who were unable to give anything but themselves for the rebuilding of Palestine, and they eagerly declared their willingness to go in any capacity. One man, who had been director of a big bank in Russia, and who had lost his position through Soviet economics, was prepared to go out as a clerk. My visits to those who were absent from the meeting were paid in the company of Mr. Goldberg, who ferreted out many strange addresses, and 


\section{I44 THE JOURNAL OF A JEWISH TRAVELLER}

who, as we sped along side by side in rickshaws, advised me how to tackle each person in turn. I called upon the oldest Anglo-Jewish resident alone, but the visit was fruitless. He declared that he must reserve his bounty for local needs, as poor Jews were,always passing through the port, and he sought to convince me of the demands upon his purse by producing a copy of the by-laws of the Yokohama Jewish Benevolent Association, founded some twenty years before. 1 Another English Jew, whose father had been an orthodox communal worker in London, and who had anglicized his name beyond recognition, told me candidly that he was a free-thinker and utterly indifferent to the fate both of Israel and of the Land of Israel ; but out of respect for the memory of his pious father he contributed something.

The most annoying experience that I had was with a young Russian Jew, who conducted a successful money exchange. It was closing time as I entered his office, and he showed me little boxes crammed with bank notes of various colours, countries and currencies, hugging those of England with tight embrace, and shaking his head mournfully over the worthless batches of Russian roubles. One by one he placed the boxes into a huge safe in a strongly secured room, turned and tried lock after lock with care, and led me then to his private room for our interview. I had scarce touched upon the purport of my visit when he left me and briskly returned to the strong-room. One by one I heard the locks being turned again; the sharp click of the closing of the safe re-echoed through the empty office; and the vision of a substantial bank-note floated before me. He came back jauntily, seated himself opposite me with an air of smug self-satisfaction, and saying, "I cannot resist your appeal," tendered me a five-yen note (then worth fifteen shillings). The pettiness of the amount was a flagrant insult. I flung the note back and left him.

1 This gentleman was a victim of the terrible earthquake in September, 1923. 
Much more agreeable was the experience that I had in relation to a Christian missionary, the Rev. O. St. M. Forester, and his wife, who attended my meeting. Mr. Forester showed me a greenstone signet-ring that he was wearing, with the Hebrew inscription, Shaalu shelom Yerushalayim ("Seek ye the peace of Jerusalem "), and told me that it had belonged to his wife's grandfather.

"And who was he?" I asked.

"Michael Solomon Alexander, the first Anglican Bishop in Jerusalem," was the reply. "Have you heard of him ? He had a rather romantic history. He was born of pious Jewish parents in Posen at the end of the eighteenth century, went to England as a young man, became a minister of the Hebrew congregation at Plymouth, and a few years later both he and his wife were converted to Christianity. He was afterwards ordained Bishop of the United Church of England and Ireland at Jerusalem, and he had the supervision of the English clergy and congregations in the whole of the Near East. The last four years of his life he spent in Jerusalem, and he died in Egypt, when on his way home to England. That explains our interest in Zionism."

The Foresters invited me to lunch one day at their pleasant home overlooking the sea, in a suburb where Mr. Forester acted as missionary to the local Chinese colony. Although not of Jewish descent like his wife, Mr. Forester also boasted of a kind of link with Jewry, for he was the nephew of the two charming sisters, Lady Bradford and Lady Chesterfield, to whom Disraeli addressed love-letters after his wife's death, as chronicled in the pages of Moneypenny and Buckle's great biography. They displayed a very keen interest in the progress of Palestine, and in the general welfare of the Jewish people. Mrs. Forester, who wore a little golden Magen David, also an heirloom, was proud of her racial origin and was anxious to be enlightened about the relations of the Jews to Bolshevism, so as to be able to refute the stories of Hebrew tyranny in Russia which circulated in the 


\section{I46 THE JOURNAL OF A JEWISH TRAVELLER}

East as in the West. Her zeal was a form of psychological atavism. She told me that she had recently had a visit from an English girl who had fled from Russia, and who told blood-curdling tales of the omnipresent Jewish commissaries. "I could smell a Jew or anybody with Jewish blood at a mile, and it would turn me sick," the girl had said.

" But I am of Jewish blood," rejoined Mrs. Forester, " and proud of it."

The girl, at first incredulous, made a humble apology to the lady whose help and hospitality she had received.

As I was about to leave, Mr. Forester, unsolicited, gave me a cheque for $f^{\text {Io }}$ for the Palestine Fund, and a Christian friend who was present also gave a token of practical sympathy.

I was the object of considerable curiosity on the part of the native press, especially after the circulation by the Kokusai news agency of the following sensational paragraph :

"A meeting of the Jewish residents in Japan was held yesterday at the office of the Jewish Association in Yokohama, in order to consider the proposed establishment of the Kingdom of Palestine (reports a Yokohama dispatch to the Tokyo Asahi). The meeting was presided over by Mr. Israel Cohen, and was attended by some two hundred Jewish residents. After an hour's conference in camera an agreement was reached, it is reported, to establish a kingdom for the Jews."

A Kobe paper, which reproduced this paragraph, facetiously remarked: "It is not stated which of the two hundred gentlemen present is to wear the crown." It was perhaps for the purpose of unravelling this secret and securing a "scoop" that so many journalists came to see me at the hotel; but as they all spoke English badly and I spoke Japanese not at all, they were none the wiser after tendering me their professional cards. One disreputable-looking individual began by addressing me 
in Russian, whereupon I at once suspected that he was a police agent bent upon discovering by a language test whether I was not really an emissary of Lenin and Trotsky. Another caller inquired whether I had received a visit from a colleague whom he named, and upon my taking some papers out of my pocket to look for the latter's card, he made a grab at the papers, which I immediately thrust back again, and he retired baffled.

But on the eve of my departure the police sent a declared representative once more. He was announced as I was busily engaged in packing, so I secured my trunk, locked the door and went to see him in the lounge. He offered an elaborate apology in the name of his chief for troubling me again, but would I kindly tell him how much money I had collected and what were the names of those who had given ? Upon hearing the amount, he affected to be surprised at what he considered such a large sum, and entered it into a notebook; but as for the list of the subscribers, I pleaded that I had already sent it to London. He even mentioned the names of certain people, and wished to know their respective donations, but I confessed ignorance of their existence and reproached him for not having supplied me with those names upon my arrival. There could be little doubt that his inquiries were prompted by a solicitude for the inland revenue.

3

Limitations of time prevented me from spending more than a day in Tokyo. There were no Jews to see there, for the only Jewish resident, the editor of an American paper, was away in the States. But I wished to call upon the British Ambassador to discuss certain questions, and likewise desired to see something of the capital. I was accompanied by a native guide from Yokohama, who displayed remarkable deference to me. He asked whether I was the Mr. Cohen about whom the Japanese press had been writing, and, upon receiving my answer, 


\section{I48 THE JOURNAL OF A JEWISH TRAVELLER}

said that he considered it a great honour to be conducting the cousin of the King of England !

"How do you make that out ?" I asked, astonished.

"Well, the papers say that you are going to make a kingdom in Palestine, which belongs to England, and so they suppose you are the cousin of the King of England."

I was loth to dispel such a flattering delusion, although I believed that my cicerone was not quite so credulous as some of his countrymen. When we approached the Imperial Palace, which is hidden behind a wall twenty feet high and surrounded by a moat twenty feet wide, a sentry forbade me to use my camera, and my unquestioning obedience must have convinced my companion that mine was but commoner's blood after all. He took me to the Shiba Park, a large, well-wooded area dotted with shrines and temples, tombs and mausolea, pagodas and monuments, lake and pleasure-gardens ; and then, with my boots encased in large felt slippers, I paced the galleries of some of the mortuary temples of the picturesque Shoguns-the mighty generals who ruled the land for seven centuries-what time a shaven-headed bonze explained in broken English the peculiarities of the antique architecture and the symbolism of the bizarre decorations and sculptures, profuse with gilded dragons, phœnixes and polychromatic peonies.

At the British Embassy, which is surrounded by a lofty wall, though one not so stupendous or cannon-proof as that encircling the British Legation in Peking, I had a chat with the Ambassador, Sir Charles Eliot, who was greatly interested in my mission and my travels. We discussed the question of the possible emigration of Russian Jews from Yokohama to Palestine; and then Sir Charles, after inquiring about his Jewish friends in Hongkong, where he had formerly been Principal of the University, told me of a visit that he had once paid to the Cochin Jews near Madras, and advised me to include that ancient community within my itinerary. One of the officials at the Embassy whom I met, Mr. Starkie, 
had more than a newspaper knowledge of Zionism, for he had worked at the Foreign Office under the late Sir Mark Sykes in the stirring days when that political idealist helped to fashion and secure the Balfour Declaration.

From the Embassy my guide conducted me to the Imperial Museum, but it was closing; and so, after driving round the Imperial University, which occupies a group of semi-classical buildings, whence 365 professors and lecturers spread modern learning throughout the Far East, we went to the huge department store of Mitsukoshi. It is a stately, concrete edifice in the Renaissance style, stocked with multifarious wares displayed as in a Western emporium. The native shoppers had to leave their wooden sandals in the entrance hall and were given straw slippers, as all the floors were covered with mats which had to be protected from rough wear. European visitors had cloth slippers put over their boots ; and more than a dozen attendants were busy all the time looking after the feet of all who came in or passed out. The most interesting spectacle in the building that I saw was a woman suddenly sink upon her knees and begin to suckle a lusty boy, who stood embracing her, whilst people walked past unnoticing, as though that were a common scene. My guide ascertained that the suckling was two and a half years of age, and told me that it was no unusual thing for Japanese mothers to nurse their children until they had completed their third year. We rounded off the day by strolling through the famous Asakusa Park, a motley exhibition ground containing the infamous Yoshiwara; and by a visit later to the Imperial Theatre, where the play began at four in the afternoon and continued with intervals until eleven o'clock, but where my patience and curiosity, after gazing at a medieval pantomimic performance extolling patriotic virtues and martial valour, were exhausted after ninety minutes.

On the way to the railway station my attention was attracted by a pleasant tintinnabulation, which I found 
proceeded from a newsboy who, after the national custom of his calling, had a cluster of bells round his waist to advertise his papers. We bought the Kokumin, which proved to contain the snapshot of myself taken in the Yokohama synagogue and surrounded by masses of picturesque reading-matter.

Another night journey by train brought me to the Mikado's quaint old capital, Kyoto, where the eye could feast upon far more scenes of beauty than in the larger and more frequented cities. It is a place of peace, piety and ineffable charm, where the genius of the land still holds its own against the gradual inroads of Occidental civilization. Its shrines are ornate and elaborate fabricsthough none so grand and awe-inspiring as the Temple of Heaven in Peking - encircled by landscape gardens and cloistral groves, in which one finds curiously gnarled trees and tall stone lanterns. At two of these Buddhist temples a service was in progress : in the one a baldheaded priest on his knees struck a gong after each verse droned out by a swarm of fellow-priests; whilst in the other, thronged with a concourse of students preparing for the sacred calling, one of the leaders in prayer tapped a little drum to mark the end of each invocation. The workshops were not less interesting than the temples; the craftsmen whom I saw squatting at their benches, silently intent upon their work in tidy and speckless rooms, were as conscientious as the priests. I watched them fashioning wonderful wares in lacquer, cloisonné and damascene, and as I sipped a dainty cup of pale aromatic tea-which it would have been discourteous to refuse-I was tempted to purchase more than one object held alluringly before my gaze.

But my primary reason for coming to Kyoto was not to study its fascinating sights, but to call upon an unknown lady who had sent me a letter through the editor of the Japan Chronicle. Her name was the Hon. Mrs. 
E. A. Gordon, and she wrote that she had been interested in Zionism since Dr. Hercl's time, and was a friend of many years' standing of Mr. L. J. Greenberg (editor of the Jewish Chronicle). " Although I am not a Jewess," her letter continued, "I have long worked for the cause, and believe strongly that these Japanese are part of the Tribes, and possess some of the proof heirlooms. 'Next year in Jerusalem!' is about to become true, and we must stir up Japanese interest."

The curiosity aroused by this missive was fully gratified. I found Mrs. Gordon an interesting old lady, lying on a couch, crippled with neuritis, yet mentally alert. She told me that she had been an ardent sympathizer with the Zionist cause from its earliest days, and was anxious to learn what progress had been made with its practical realization. She had lived in China and Japan for several years, knows the languages of both countries, and tried to prove her strange theory that the Japanese are part of the Lost Ten Tribes by advancing various data respecting names and customs, which seemed to me easily explicable on the ground of accidental similarity. She said that a few years ago Professor Pysacki, of the Waseda University, Tokyo, wrote a book on The Nestorian Monument in China (published by the Society for the Propagation of Christian Knowledge), in which he showed that the Chinese word " Ta-chin," used by the Nestorian monument for Syria, corresponded to the Japanese Uzumasa, the name of a village in which was situated a well, 1400 years old, marked "Israel " in Chinese characters. Recently a new well was constructed in the same village, incised with the same characters "Israel." In this village, on a certain midnight, the inhabitants eat flat rice-cakes called Mochi (supposed to be the same word as Matzo), an observance named "Victory over the Rice-Bread." Furthermore, in the Inland Sea, about a couple of hours' sail from Kobe, there is a shrine called "O-ho-saki," which means "Beloved," and as David also has the same meaning, Mrs. Gordon styles it " David's 
I52 THE JOURNAL OF A JEWISH TRAVELLER

Shrine." In the vicinity of this temple are villages named "Goshe" and "Menasseh," and there also used to be a shrine called "Ephraim."

But there were even some stranger pieces of "evidence," drawn both from ancient and modern times. About the year 96 of the Common Era a Jewish cenobite, named Jun-tu-la, was recorded to have come to Kai-feng-fu, where later the well-known Jewish colony flourished. In the year 370 a Tibetan monk named Jundo (" Follower of the Way "), who was sent by the Emperor of China to the Northern Kingdom of China, came to Pin-yang, where he founded two Buddhist Temples, one of which, according to Professor Anesaki, of the Imperial University of Tokyo, was styled "Ilfullan," a word that was rendered "Ephraim" on the Nestorian stone. As for modern times, Mrs. Gordon was told that at the coronation of the late Emperor of Japan the merchants in Osaka hung out flags with Hebrew letters. But what she vouched for herself was even more romantic. She said that at Ise there are two shrines, built after the model of the Biblical Tabernacle, one consecrated to Earth and the other to Heaven, which are renewed every twenty years from the choicest woods of the Emperor's forest. Nobody except the Emperor may contribute the timber, but ordinary folk could give plain white stones. The treasures are then removed in the darkness of night by blindfolded priests from the old shrines to the new, whilst the scene is illuminated by torches (though how the priests can see what they are about I fail to understand). Mrs. Gordon stated that she witnessed such a ceremony a few years ago, when a French lady who was present exclaimed "Les rideaux!"-the curtains of the shrine being said to be like those of the Tabernacle.

This stream of curious information came pouring without pause from the lips of the old lady, as she lay helpless on her couch. Her mind went back to the days of Queen Victoria, whom she had served as a Lady-inWaiting; she told me that the late Queen was a believer 


\section{JAPAN}

in the British-Israel theory and insisted that the newly born son of the then Duke of York, that is, the present Prince of Wales, should be named David, because it was he who was destined to lead the Jews back to Palestine. As I was about to leave she reached over to a table beside her and presented me with two works of hers, in which she had written: "With the Author's best wishes for Zionism. Kyoto- ' The City of Peace." " One was an entertaining volume of travel, Clear Round! written thirty years ago, and giving a graphic description of life and customs in the Far East; the other, entitled The Lotus Gospel, was a comparative study in Buddhist and Christian theology, with mystical diagrams and references to Jewish lore. She also gave me a small black leather case containing a few photographs that she had treasured for many a year. Three of them were photographs of the Prince of Wales, taken at different periods of his childhood, the first as a month-old babe on his mother's lap. At the back of the photograph of the Prince, when an infant of two in petticoats, was pasted a picture postcard of Herzl, with his name in Hebrew, published by a pre-war firm in Warsaw.

The conversation had been so absorbing that I suddenly realized that there was scarcely sufficient time to catch my train for Kobe. The rickshaw-man flew with me through highways and byways by the quickest route at a madcap speed that soon caused streams of perspiration to trickle all over him, and upon arriving at the station he panted piteously. But he had enabled me to board the train in time and he was content with his reward.

A few months later I was in Jerusalem, and upon relating to the High Commissioner my experiences in Japan, he told me that he had just received from Mrs. Gordon a cheque for $£ 500$, to be distributed at his discretion among various deserving purposes. A few months later still I narrated my experience to Mr. L. J. Greenberg, who then disclosed the interesting fact that the donor of the $£ 2000$ which had enabled the Zionist 
I54 THE JOURNAL OF A JEWISH TRAVELLER

Organization in Ig03 to send a commission of investiga tion to the territory in British East Africa offered by the British Government for an autonomous Jewish settlement was the self-same Mrs. Gordon.

5

Arrived in Kobe once more on the Sabbath eve, I was met by Mr. Yabroff, who told me that police permission had meanwhile been obtained for the meeting, which would take place that evening in the synagogue. It was the first time that I had heard there was a Jewish place of worship in the town, but it was immediately explained that it was situated in a private house. Mr. Yabroff took me to his home, where the Sabbath candles gleamed on a snow-white cloth, and a repast was served of truly traditional quality, with lockshen soup, stewed carp and boiled chicken.

When we entered the synagogue, a large room on the upper floor of a humble dwelling, we found a few friends already waiting, together with two police representatives in plain clothes. The shrine was plainly furnished, with a simple Ark and reading-desk made by a local carpenter, whilst on the walls were displayed Zionist flags. My address was brief, and it was followed by a fervid appeal in Russian by Mr. Yabroff for the enlightenment of those who could not understand me. Various donations were promised, which, together with the amounts already contributed, brought up the total for Kobe to $£ 200$. The formation of a Zionist Society was then formally resolved upon, and glowing hopes were expressed for its future; but owing to the fluctuating character of the little Jewish colony those hopes have failed to blossom.

Once again I made an all-night journey, with Shimonoseki as my destination. At Yokohama I had repeatedly discussed the advisability of sailing from Tsuruga to Vladivostok, whence I wished to reach Harbin; but so many strange tales were poured into my ears about the Bolshevik sailors of the ship on which I would have to 
sail, about the uncertainty of landing at Vladivostok, about the insecurity of life in that city, and about the oft-interrupted connection with Harbin, that I resolved to omit Vladivostok and to travel to Harbin through Seoul and Mukden. I had scarcely stepped out of the train at Shimonoseki than I was approached by a smiling young fellow, who first addressed me in Russian, and upon my replying that I did not understand, immediately. asked me in English for my papers of identification. The sight of my British passport evoked a momentary expression of deference. But the dapper little detective was not satisfied until he followed me into the local hotel, where I made a hurried breakfast, and catechized me in detail concerning all my movements of the last ten days. At length he released me, baring his teeth with a farewell smile, and I boarded a Japanese steamer for Fusan. - 


\section{CHAPTER XX}

\section{MUKDEN}

7 SHOULD never have suspected that there were any Jews in Mukden, but when in Kobe I was given the name of one who lived there, and was told that through him I should doubtless discover others. But the problematical results of such a discovery would not have attracted me to that ancient city had this not been on my direct route to Harbin. And so after twelve hours of the stormy waters and sombre skies from Shimonoseki to Fusan, and twelve hours in a surprisingly comfortable train; after a day in Seoul, where the most notable sights are the whitegarbed Koreans with their comical little top-hats (protecting their top-knots) and the significantly numerous Japanese police-stations; and after travelling another twenty-four hours on the South Manchuria railway, past hundreds of mud-houses buttressed with sandbags and thatched with straw, through hundreds of miles of flat snow-covered landscape, I arrived one dark and dreary morning in the dismal station of the old Manchurian capital.

The English-speaking Japanese clerk at the Yamato Hotel, whom I asked the location of the only address that I had, advised me to take a carriage to the Chinese Post Office and ascertain there its Chinese equivalent. $\mathrm{He}$ gave instructions to a stupid-looking driver, a big hulking fellow in a huge fur-lined coat, who drove me in the teeth of a cold wind to the Post Office situated half a mile away. There I presented my English note to a smiling official, who, after a few minutes' search, wrote upon it 
the equivalent in Chinese characters and returned it to me with many bows and smirks. I showed the precious little document to my driver, whose stolid dirty-yellow face, swathed with ear-flaps, slowly expanded into a smile of comprehension; and off we went at a steady trot along primitive broad thoroughfares, bustling with traffic, and bordered by booths and stalls of multifarious mouldy wares, through one of the broad gateways of the outer bailey. This massive wall, built of mud in I680, is thirteen feet high and ten feet wide, and encircles the vast sprawling city like a colossal quadrangle ten miles in circumference. Within, a mile away, I caught a glimpse of the grim bastions jutting over the black brick walls of the inner bailey of the fortified city, a square enclosure, thirty-three feet high and three miles round.

Midway between the two encircling walls, after cleaving a path through crowds of curious pedestrians and loafing porters, all closely muffled against the cutting blast, and after jostling against swarms of ox-carts and rickshaws, we reached our destination. It was a substantial, onestory stone-built house surrounded by a stone wall, with a pair of fierce stone dogs guarding the doorway.

The occupant was at home. He was a young American Jew, Mr. Herskowitz, who lived there with his wife and recently born child. He had read of my mission in the Shanghai press and gave me a most fraternal welcome. He invited me to stay to lunch, at which we were joined by a young English Jew, Mr. Silverberg, of London, and we had an animated exchange of news.

"If you think there's a Kehillah' here, well you're mistaken," said Mr. Herskowitz. "There isn't even a Minyan, ${ }^{2}$ not that that causes us much worry. But we have a calendar, and so we know when Passover or Yom $K i p p u r^{3}$ or anything else is coming. The first Jew born in Mukden, I am right proud to say, is my little son. He came into the world three months ago, and we got a

1 Congregation. 2 Quorum of ten for prayer.

Day of Atonement. 


\section{I58 THE JOURNAL OF A JEWISH TRAVELLER}

Mohel 1 from Harbin. The circumcision party was the first Minyan we ever had in this musty old place, and gee I didn't we have a jolly old time ! Besides us two there are only six other Jews here."

"And what do you all do?" I asked.

" Furs," was the laconic reply. "Hides too a little, but mostly furs. It's beastly dull, but we're going to stick it like heroes for five years-make the most of it and then cut across the Pacific again to good old America."

The dulness was soon relieved by the wailing of the infant, who was brought in by the proud mother and resented being made an object of exhibition, so it was at once removed by its native nurse with some soothing Chinese syllables.

My host required no conversion to the merits of my mission, and both he and his friend gave their contributions quite cheerfully. Hearing that I intended leaving the same evening for Harbin, he warned me of the Arctic cold I should encounter and made me exchange my heavy overcoat for a still heavier fur-lined coat and my trilby hat for a round one of fur, so that on looking into a glass I felt translated. "We can exchange back again on your return," said Mr. Herskowitz.

He then took me to one of his Jewish friends, who had a Christian partner. The Jew scoffed at the idea of a Jewish resettlement in Palestine, but the Christian, who was a firm believer in the British-Israelite theory, upbraided him and quoted texts from Isaiah to his discomfiture. Unfortunately two of the other Jews were away at Tientsin, and on reaching the house of the sixth, which included his business premises, I found that he also was away, but his two Jewish employees, both natives of Russia-the remaining members of the octette -were pleased to see me. One spoke Hebrew fluently and was an ardent Zionist, but he had recently obtained his position and had nothing to give. The other, an asser-

1 Circumciser. 
tive little fellow, spoke Yiddish and at once declared that though he could give he would not.

"Why ?" I asked in astonishment.

" On principle," he replied. "I am a Bundist. I believe that we Jews in Golus shall find our salvation only in Socialism. For me Palestine is a chimera. But I am willing to help you morally," he added in a conciliatory tone, "with some names and addresses in Tientsin."

I noted the names, but discounted their value in advance. It was useless continuing the argument, so I had a carriage called and the Bundist explained to the driver that he was to take me into the inner city before returning to the hotel. It was already dusk as we drove through a succession of roads until we came to one of the gateways of the inner bailey, which was like a tunnel, the wall being twenty-six feet thick at the bottom; and on emerging we traversed several crowded streets, lined with prosperous-looking shops, until we came to another tunnel-like gateway and made for the outer bailey.

The picturesque towers on the walls looked grim in the dusk, and high above all the buildings soared the imposing pile of the old palace of the Manchu Emperors, whose characteristic colours of yellow, red and blue were blurred into a sombre monotone. In the distance, standing in a vast peaceful plain, and silhouetted against the sky, was the tall monument commemorating the decisive Battle of Mukden, a cannon-ball crowning a pile of stones. The ghosts of the past seemed to flit through the air as we drove through the darkness, and I thought of the thousands of Jews who were slaughtered here in the defence of a land that had always oppressed them. Their bones might lie buried beneath the very ground over which my carriage rumbled. . . .

As I was a stranger, the driver, like all members of his ancient calling, had taken the most circuitous route, and I almost despaired of reaching the end of the cold and tedious journey when I saw the welcome lights of the hotel glistening ahead. 


\section{CHAPTER XXI}

\section{THE CITY OF HARBIN}

7 LEFT the dismal, frowsy city of Mukden in the evening, and travelled northwards in a comfortable sleeping-car, well lighted and heated. At 1 half-past seven the next morning, without untoward incident, I arrived at Changchun station, which could compete in smell, dirt and disorder with any railway station in Poland. Here I had to change and get my luggage registered afresh, an operation that cost much trouble and anxiety, as, after all the disquieting stories I had heard, I wished to convince myself that my trunk was actually placed into the van. The station was guarded by a number of Chinese soldiers, looking cold and stolid, and every place that we passed on the way enjoyed a similar protection. The land around us was flat and uninteresting, buried beneath snow and frost, with a dull grey sky above ; and the swarm of hulking, grinning hawkers who appeared at every wayside station with baskets of cackling geese soon lost their novelty. The train of the International Sleeping Car Company in which I travelled seemed a symbol of safety and civilization in this remote outlandish region, and the glasses of weak tea that were brought to me by the Russian attendant from the steaming samovar in his cosy cubicle at the end of the car infused a feeling of warmth and comfort. At half-past five, twenty-one hours after leaving Mukden, we rumbled into the vast roaring station of Harbin.

Among the many curiosities of the Far East Harbin holds a secure position. It is a Russian city on Chinese territory: the only Russian city beyond the frontiers 
of Russia. It is also the youngest Russian city-perhaps, for its size and population, the youngest city in the world, for thirty years ago it was but a village of fishing-huts and now it is the most important commercial centre and central grain-market in Manchuria, with a population of over Ioo,000. It is probably also the only community that has been developed and administered, not by a Government or municipality, but by a railway company, for it has grown up under the fostering care of the Chinese Eastern Railway Company, with the joint blessings of the Russian and Chinese Governments. Its phenomenal rise is due to its forming the junction on the Siberian and the Chinese Eastern Railways, and as its territory was endowed with neutrality it soon acquired cosmopolitan popularity. But this neutrality has been affected by the war. At first the Russian "Whites " controlled the city, but after the departure and the downfall of Koltchak the Chinese asserted their dominion over it to prevent its falling into the hands of the Bolsheviks. They drafted troops into it and replaced the Russian police by Chinese. But a small Soviet, a " Union of Trade Representatives," which passed long-winded yet futile resolutions on current affairs, was openly tolerated ; and not many miles away there were some thousands of Japanese troops who betrayed no signs of departing and to whose proximity was due the prevalence of the yen. Harbin thus enjoyed the threefold novelty of being a Russian city on Chinese territory with Japanese currency.

It was the coldest city in which I had ever been, and although I wore a heavy fur-lined coat, a fur hat and thick woollen gloves I felt several of the twenty degrees of frost that were registered on the thermometer. The streets, both pavement and. roadway, were thickly covered with ice, so that goloshes were necessary for safe walking, the women wearing ugly fur-lined goloshes over their high shoes. Within the hotel it was uncomfortably and even oppressively warm, thanks to the perfect system of central heating and the equal perfect system 


\section{I62 THE JOURNAL OF A JEWISH TRAVELLER}

of keeping the windows hermetically sealed throughout the winter. The windows were generally double, with a layer of cotton wool between the frames, as a single window, with extremes of temperatures on either side, would be exposed to the risk of cracking. Whenever I stepped out of the hotel into the street I felt little icicles form on my moustache, and when I came back into the warmth my frosted glasses became dim with vapour. But the climate, I was told, was really mild in comparison with what it was further north, and my astonishment was further aroused on hearing that in summer it was usually eighty degrees in the shade, when some of the ice of which there was now a surfeit was welcome. The only inhabitants that were unaffected by the rigour of the climate were the hardy Mongolian ponies, which were harnessed in pairs to the droshkies. These animals were always in the open air, they slept in stables without roof or door, and there was a permanent coating of frost on their rnanes and noses. They galloped along so wildly that they often rushed on to the pavement, and after a few yards returned to the roadway, to the alarm of the uninitiated stranger who happened to be in the carriage.

Harbin's population is largely Russian, including some ro,000 Jews, for the laws of the Tsar confining his Jewish subjects to the Pale of Settlement did not apply to this neutral territory. Half of the Jews were settled there before the war, the other half have been attracted to it as by a city of refuge : they have come from every province, and almost every town in the Empire, fugitives from the terrors of war, Bolshevism and famine. They are mostly congregated in Pristan, the commercial quarter, where they have an imposing high school, two large synagogues, an orphanage and other communal institutions. The Chinese occupy a separate quarter, where they carry on two or three flourishing markets in the open air. But the most interesting element in the population consists of those who until quite lately had taken an active part in the war. There were, on the one 
hand, former Russian officers who had either been disbanded or had deserted, and there were, on the other hand; former prisoners-of-war, Germans, Austrians and Hungarians, who had been released or had escaped and were unable to get home. In the general economic depression that prevailed these retired warriors enjoyed a disproportionate share. The waiter who served me in the hotel had been a lieutenant in the Hungarian army, and although his livelihood was derived solely from the tips of none too generous guests, he considered himself lucky beside the thousands of others who aimlessly tramped the frozen roads.

"If I gave up this job," he said, "there would be a hundred eager to take it. I know of a Russian general who has become a coachman, and of some majors who couldn't even become that because they had only been in the infantry. There are Russian nobles who have sold everything except their fur coats. There are Russian princesses who have opened a café, where they serve tea to those who might before have swept the street in front of their palace. And I know of a former Austrian prisoner who has become a tailor, to whom a Russian captain applied for work."

The residents in Harbin spoke of it as a kind of Klondyke, because of the rapid growth of the city and of many fortunes that were made in it, because of the adventurers and adventuresses who came and went, and because of the reckless gaiety that reigned at midnight. But the dominant impression that was produced upon me was of a place seething with unrest, intrigue and insecurity. Everybody was debating whether the "Reds" would try to win the city for the Far Eastern Republic, or whether the Japanese would march in some fine morning, or whether the latter were merely watching the former and the Chinese would be left alone. The Chinese police were conspicuous enough, for they stood in the middle of the road, where they rather obstructed than directed the traffic; and at intervals, in the main 
I64 THE JOURNAL OF A JEWISH TRAVELLER

thoroughfare, one came across a moving mass of shaggy sheepskin which contained a Russian policeman with frozen nose, who was retained for the convenience of the inhabitants. But despite these apparently efficient measures of vigilance, burglaries were frequent and property was insecure. The robbers were recruited indiscriminately from ex-soldiers, ex-prisoners, ex-policemen, deserters and fugitives, who easily disposed of their booty in the Chinese markets. Contempt for the eighth Commandment had been systematically disseminated by the Czecho-Slovak soldiers, who, in their homeward march across Siberia, had forcibly annexed everything they could lay hands upon-food, clothing, jewellery, clocks, and even pianos and articles of furniture, which they sold at ridiculous prices on the way. And thus many a private house in Harbin was now protected by an armed soldier or two, whose sentry-boxes seemed to suggest that the house was the residence of a Grand Duke.

There was a chaotic jostling of wealth and poverty, of pleasure and suffering, of work and idleness, pervaded by a general feeling of tremendous isolation from the great world without and of uncertainty about the morrow. Smartly dressed women in expensive white furs, diffusing delicate perfumes, were accosted in the street by wretched beggars, whose shivering bodies were covered only with rags, matting or plaited straw, and who sank imploringly on their knees. These beggars, pale victims of famine, would even throw themselves at the feet of people driving in a droshky, heedless of the galloping ponies, and point with shrivelled finger at their parched lips. Chinese women, with a child strapped on their back or a baby clutching at a withered breast, would stand for hours on the busy bridge over the Sungarei River, marvellously unscathed in the swirl of ceaseless traffic ; and opulentlooking men in fur coats and sealskin collats passed on unheeding, for they were the rouble millionaires whose wealth had become overnight mere scraps of paper, and who now lived on the charity of their friends. 
The cost of living was high, for the unit of currency, the yen, had risen to three shillings, and everybody was at pains to make ends meet. The taxicab driver who brought me to the hotel from the station, a ten minutes' drive, demanded ten yen, and when, in astonishment, I appealed to the manager he confirmed this as the official tariff. Later I handed a letter to one of the messengers in the vestibule to post, and presently I received a bill for one yen. "What is this ?" I asked of the manager. "It is quite in order," he replied. "We can't pay our messengers, and how else are they to live ?" The housing question had been rendered acute by the great influx of population during the last few years : rents had soared high, and houses and flats were nowhere to be found. So a few enterprising people, noticing a big stretch of land lying waste beyond the railway track, solved the question for themselves by building there houses and shops of timber. The example spread, and within three months a new and extensive quarter had sprung up, a regular " Timber Town," with spacious and uniform streets and every house surrounded by a commodious courtyard, containing fully 2000 residents. Thereupon the municipal authorities, suddenly realizing what had happened, began to formulate their demands for rent, which were met at first by refusals and then by stubborn haggling.

But despite the high cost of living many people seemed to maintain a lofty standard, their bountiful hors d'cuvre surpassing an ordinary man's dinner. The principal restaurant was busiest between two and five in the afternoon, and from ten at night until the small hours, for most people went to bed late and rose correspondingly late. There were few theatres, but many picture palaces with thrilling American films, and a perfect plethora of cabarets. These midnight " concert-halls," as they were euphemistically designated, were advertised as "gay, brilliant and cosy," some of them offering the further attraction of "plenty of air." It was here that the gilded 
youth, cosmopolitan adventurers, and the demi-monde, with the bourgeois in search of Bohemian pleasures, fore gathered to eat, drink and be merry whilst songs and dances of dubious virtue were rendered to the strains of a jazz band. But the more serious element belonged either to the Railway Officials' Club or the Commercial Club, though even here baccarat was played into the small hours, devoted wives sitting beside their husbands at the green-baize tables until fatigue or losses drove them home.

It was at one of these clubs that I heard strange stories of military adventurers and political mountebanks, of espionage and counter-espionage. Some German officers, late prisoners-of-war, had offered their services to England for intelligence work, and having been refused, applied to Japan and were accepted. Koltchak, I was told, had fallen out with Semenoff, not on the ground of politics or strategy, but simply on account of a woman, for here as elsewhere politics were curiously intermingled with passion. And then I heard of a beautiful Scotswoman, flaunting an aristocratic title, and pretending to be an agent of the British Government, who succeeded in getting lavish sums for the alleged purchase of ammunition, with which she disappeared in the company of a suspicious Pole who flew an American flag on his motorcar. Any week, any day, other adventurers might come, for this was a fruitful field, and having flashed across the horizon of Harbin, vanish into the beyond. 


\section{CHAPTER XXII}

\section{HARBIN JEWRY}

\section{I}

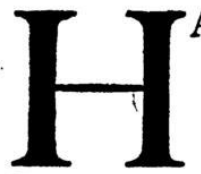

ARBIN Jewry would be a typical RussoJewish community were it not free from most of the ills and misfortunes to which It has nevier seen a pogrom or "oblava" in its midst, nor has even the nagaika ever been cracked in its hearing. Most of its members have, indeed, individually made the acquaintance of these sinister products of Muscovite civilization, but that was when they were still writhing in the talons of the Russian Eagle. Harbin, however, as the important junction of the Chinese Eastern Railway, in whose welfare China was concerned equally with Russia, was made a neutral city, where the eagle was transformed into a dove. It enjoyed immunity from the mass of galling laws that harassed every community in the pale of the Settlement ; and thus from scores of towns and townlets that languished under the Tsarist yoke there steadily dribbled human rivulets to this city of refuge in the plains of Manchuria. From Suwalk and Saratov, from Kiev and Kishinev, from Kovno and Odessa, as well as from the nearer cities of Omsk and Tomsk, hundreds of Jews, with their wives and children, began twenty-five years ago to trek to this flourishing asylum, settled in the Pristan quarter, and gave a healthy impetus to the commerce of the entire region. Before the war the community already counted 5000 souls; by the end of the war it had doubled and thus become the largest Jewish centre in the Far East. Many of its members had made 
fortunes by trading in grain, timber, hides and furs, and had lost them again in the back-wash of the Russian Revolution, their millions of roubles shrinking to the value of the paper on which they were printed. But there were others whose fortune was largely invested in property, or who had converted their roubles betimes into Chinese or Japanese currency, and had thus escaped the economic typhoon that had wrecked so many lives. The fortunate few, however, had now to bear the increased burden of the community, which otherwise threatened to collapse; and the burden was not light, for it comprised two large synagogues, and some small ones, a Talmud Torah school, a home for the aged needy, an orphanage, and a school-locally known as the Jewish Gymnasium - of imposing proportions, besides a vast number of poor, unhappily supplemented from the hosts of Austrian and Hungarian prisoners-of-war. At the time of my visit there was a strike of teachers at the Gymnasium for the sufficient reason that their salaries had not been paid for several weeks, and the non-payment, I was told, was due to the equally sufficient reason that there was no money. To expect aid, therefore, in these circumstances, for the rebuilding of Palestine required no little courage and boundless confidence.

The Jewish community of Harbin is now the most accessible Russo-Jewish community in the world, although it is separated from Shanghai by a four days' journey by express train. Geographically it is less than half that distance from Vladivostok, but although steamers from both Japan and China sail to that Siberian port, its unsettled political conditions and general insecurity make for its effective isolation. Vladivostok Jewry thus keeps in touch with the outside world mostly through Harbin, which, by illicit and ingenious means, designed to penetrate the barriers set up by the Soviet Government, acts as the main channel of communication with the Jews throughout Siberia, and, indeed, with those in many parts of European Russia too. My visit 



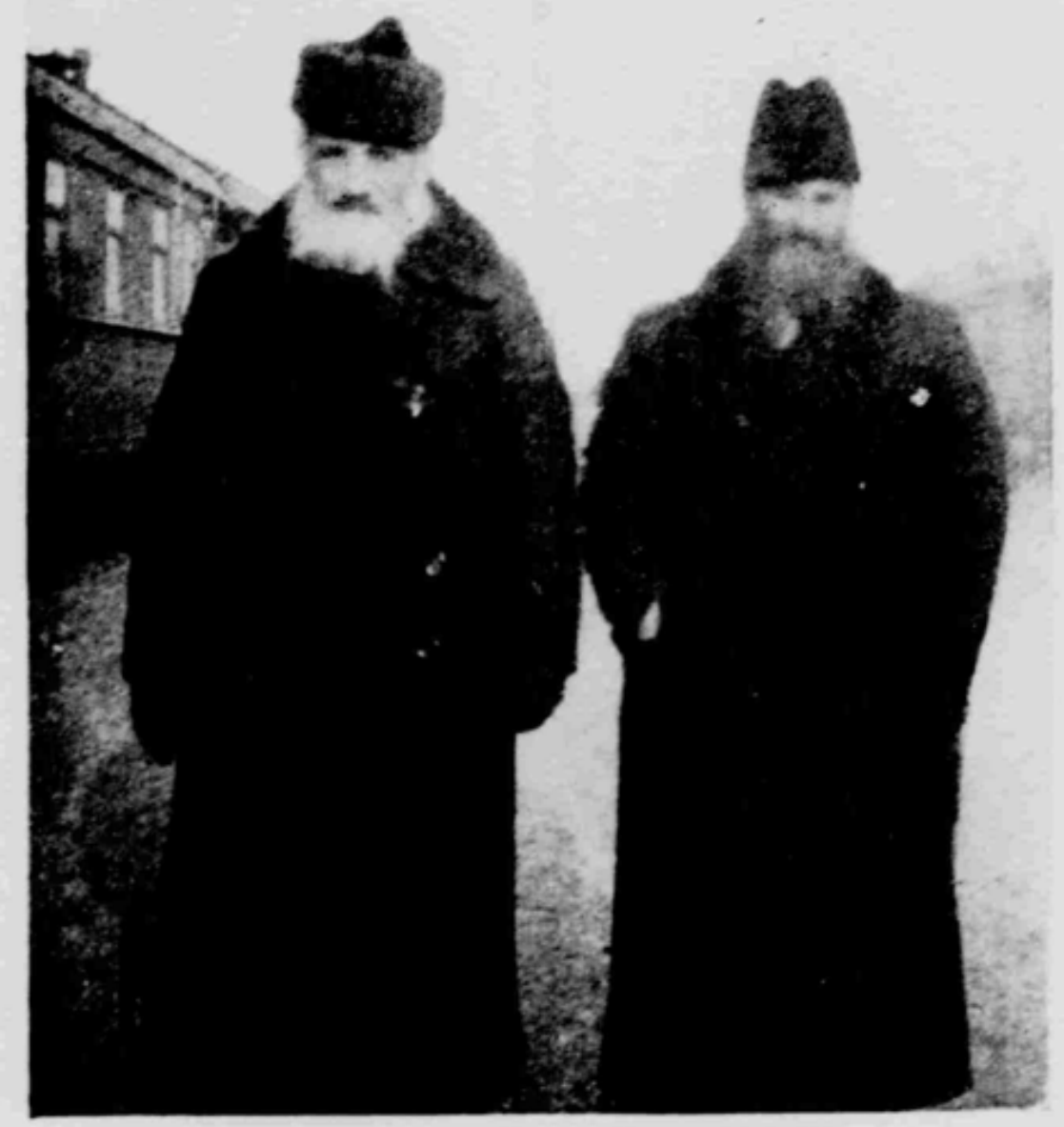
KABBI KISSEI.HOF,
OF HARBIS
RABBI LEVIS,
OF CHITA

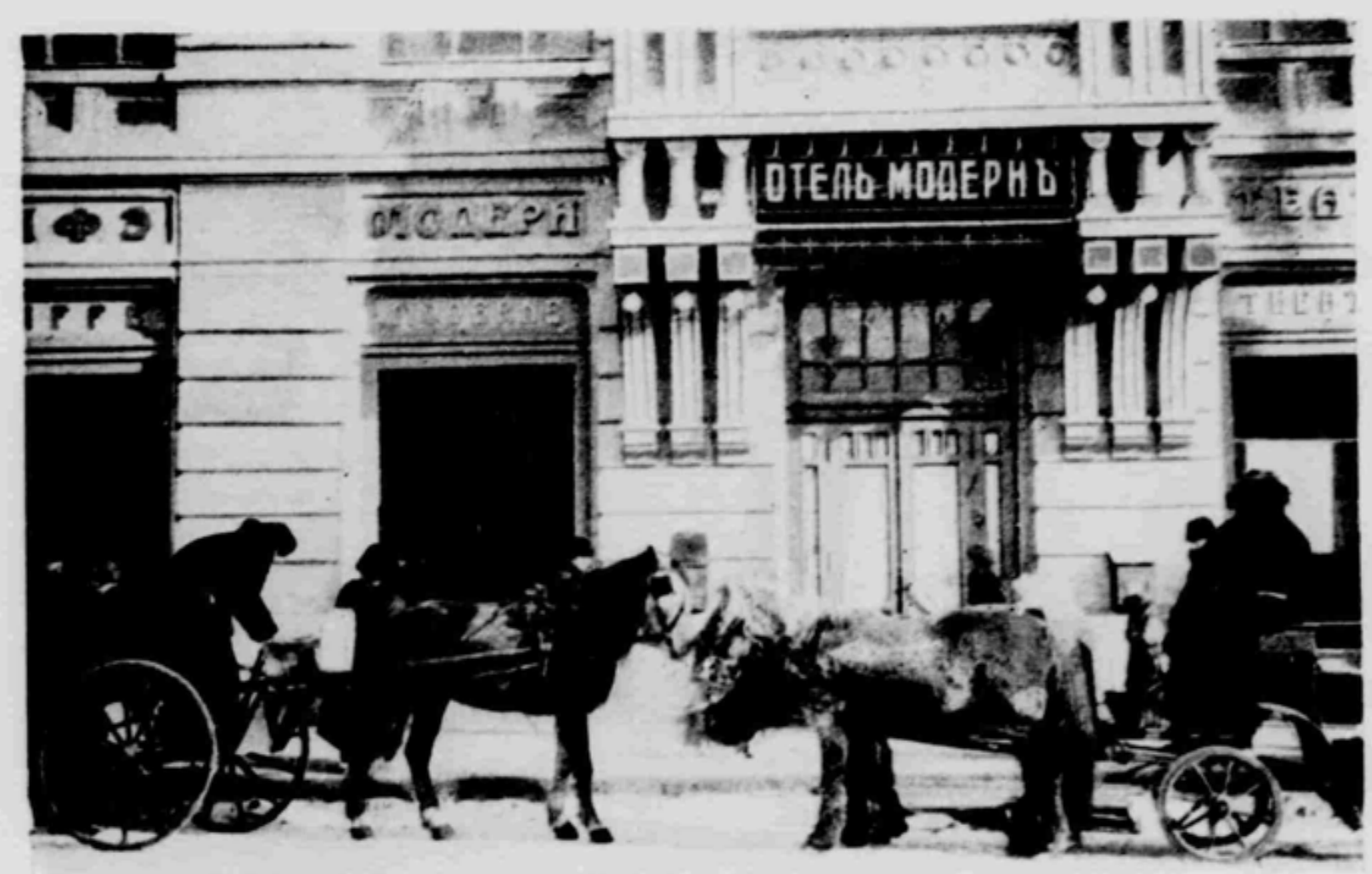

HOTEL MOIERXE., HAKIIN 


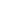


was thus regarded as of more than local interest, and delegates had come from Vladivostok and Irkutsk, from Chita and the town of Manchuria, to learn from me all that was happening in the great world beyond, especially in the Land of Israel. In our conversations there was at first a good-natured conflict, for I was just as eager to extract information from them as they were from me, and my stay was limited; but I compromised by telling them that the tidings I had brought would best be communicated at meetings, whether public or private, otherwise I should have to repeat the same story a hundred times. So a number of pnblic gatherings were arranged, leaving me free to utilize all private intercourse for my own enlightenment.

I could not help being struck by the spiritual vitality of the community, which more than compensated for its material distress. Its vigorous Jewish consciousness manifested itself in a struggle of parties, in which the Right, Centre, Left and Extreme Left were always busily engaged, and for which the prevailing slump in trade afforded ample leisure. The community enjoyed autonomy in regard to all its own internal affairs in a much greater measure than any other Russo-Jewish community since the eighteenth century. Every Jew, whether he was a member of a synagogue or not, whether he subscribed to communal charities or not, had a vote in the elections for the Communal Council; and the Bundists, who shunned the synagogue on principle and abstained from contributing towards the collective revenue, perhaps from lack of capital, always took an active part in the elections with a view towardis the dissolution of the community into its component units. When I asked why the Bundists should act as members of a community which they wished to dismember, I was told that they could work for their end only by being inconsistent, and when I asked why they were allowed 
to vote when they did not share in the common burden, I was told that in a proper democracy the suffrage must be exercised without regard to taxation. There was thus no lack of excitement. Indeed, the interminable discussions that went on, especially on a Saturday night, in the hall of the Gymnasium, between the rival adherents of Zionism pure and simple, Zionism without orthodoxy and orthodoxy without Zionism, Zionism with Socialism and Socialism without Zionism, Territorialism in Palestine and Bundism in Siberia, Hebraism in Manchuria and Yiddishism in Palestine, and endless permutations and combinations of all these conflicting conceptions, showed me that Harbin had not been seized of the realities of the Balfour Declaration, that it still fed on the pre-war ideology, and I shuddered to think how much more backward were the communities that were penned within the Chinese Wall erected by the Bolshevik Government.

I was present at several of those discussions. They were called "Sobodka," because they were held on Saturday night, and they were generally attended by an eager audience of a few hundred. The speeches had to be delivered in Russian, though many speakers would have preferred Hebrew or Yiddish, owing to the Chinese police representatives who were always present and wished to be able to follow the flow of argument. It was a Russian practice taken over by the Chinese authorities, and as they were in fear of an attempt by the Soviets of the Far Eastern Republic to annex Harbin they scented Bolshevism at every public meeting. But whether the Chinese officials really understood some of the hairsplitting deliverances on Palestinian Territorialism or on the complexities of Galuth psychology I rather doubt, even though they smiled occasionally.

A convivial atmosphere was diffused at these forensic tourneys by the distribution of glasses of tea by a Chinese attendant, and rival protagonists would help one another to sugar. 
3

The great synagogue presented an impressive spectacle on Sabbath morning. It was a large and lofty shrine, in which hundreds of fur-capped worshippers; wrapped in ample talith, ${ }^{1}$ swayed in vigorous devotion. At the lower end was a small open chamber where the Chassidim conducted their more demonstrative service, from which they occasionally strayed to the greater throng without. The Shammash, ${ }^{2}$ a rather bumptious individual whom I at first mistook for the Parnass, ${ }^{3}$ conducted me to the upper end, where I was given a seat near the Rabbi of Harbin and his reverend colleague from Chita, Rabbi Levin, who was on a visit. I realized the importance of the beadle when he took up a position in front of the Ark, delivered three resounding slaps to his innocent Prayer Book, and began to offer up by auction the honour of being called up to the Law.

"One rouble-Cohen! Two rouble-Cohen! Five rouble-Cohen I" he cried, keeping a wary eye on each succeeding bidder. He used the term rouble simply as the traditional unit, though everybody knew that he meant the Japanese yen, which was worth many thousands of roubles. When he reached the last "lot," the coveted Maftir," the bidding soared unusually high, and the honour was secured for ten yen (then worth thirty shillings) by my Sabbath host, Mr. Drisin, who graciously transferred it to me. Apparently I discharged my task to the complete satisfaction of the critical Shammash, for he not only tendered me the conventional congratulations with a hearty handshake, but even added deferentially: "Reb Yisroel, wet Ihr efsher a bissel sogen?" (Mr. Israel, will you perhaps speak a little?)

The suggestion almost took my breath away. I humbly but firmly declined the honour, urging that the community would have other opportunities of hearing me.

1 Praying-shawl. 2 Beadle.

Warden.

- Reading from the Prophets. 
I72 THE JOURNAL OF A JEWISH TRAVELLER

As I was leaving the synagogue I was accosted very familiarly by a red-bearded man, with hollow cheeks and strangely glinting eyes. "When can I journey to Erez Israel?" he asked. "Tell me. I have waited for you for months. I am quite ready. Perhaps I can go with you."

"I have many countries yet to visit," I said.

"Never mind, I can go with you to them all," he replied eagerly. "I have already packed up. Take me with you. You will earn a Mitzvah."1

My host gently parted us, and as we wended our way through the snow-clad streets he told me that the man was a Galician ex-prisoner-of-war, who had become mentally unbalanced in Russian captivity, and now eked out a living as a Hebrew teacher. Through his aberrations he had become a well-known character, penetrating into various people's houses uninvited, causing interruptions at public meetings, and rousing everywhere both annoyance and pity.

Rabbi Levin, who accompanied us, told me of the tyranny of the Soviet rule at Chita and of the impossibility of doing anything in Bolshevik Russia for the sake of Zion. He was anxious to go to Palestine as early as possible and could take a great deal of capital with him from wealthy friends for business undertakings. At our host's house, where there was a large family gathering, I met a young Jew from Prague, who had been a prisoner three years in a Russian camp and had there improved his knowledge of English to such advantage that he acted as tutor in that language and others to my host's children. He spoke English quite passably. Before the war he had been a student at the Vienna University, but it was futile now to dream of resuming his career there. Could he go to Palestine, he added, and would the University of Jerusalem soon be open? He longed for some glimmer of hope.

I soon realized that there were not scores but hundreds of Jews in Harbin who were eager to go to Palestine, and

2 Act of religious merit. 
many of them indulged in the fond dream that I could expedite their journey. The manager of the hotel at which I stayed had qualified as an engineer at a Swiss Polytechnic, and in the sudden slump had grasped at his present position solely to secure a livelihood. He wondered whether there was any opening for him in Palestine. I received many callers, mostly young men, who were all anxious to know whether I could facilitate their journey to that land of hope. A young Hungarian, who could find no employment, told me that he had had only one meal a day for a week, and unless he collected a few yen that he still owed for his overcoat he would have to return it and be exposed to twenty degrees of frost. $\mathrm{He}$ would do anything in Palestine, but how could he get there?

One morning I received a visit from an Austrian exofficer who had been engaged in business in Harbin for some months and had saved some money. He told me of a craftsmen's union which a number of industrious Jewish prisoners had formed under the name of " $\mathrm{Ha}$ Nemalah." (The Ant) in their camp, and which had so pleased the Bolshevik Commissaries that they released them. He told me, too, of the wonderful devotion displayed by thousands of Jewish prisoners to the cause of the restoration of Zion; how they organized classes for the study of modern Hebrew, how they printed their own journal in captivity, and how many of them fasted twice a week and contributed what they thus saved to the Palestine Restoration Fund. Could sacrifice any further go ? . . . He wished to join a batch of released Jewish prisoners who were being repatriated in a few days from Vladivostok, especially to receive permission to land at Port Said, so as to travel direct to Palestine and join his brother at Rehoboth, for these repatriated prisoners, as a rule, were not allowed to disembark before reaching Trieste. I was able to assist him, and months later I heard that he had reached Rehoboth safely and took part in the defence of the colony from the Arab attack in the tragic week in May, I92I. 
The Gymnasium, with its abundance of rooms, discharged a variety of functions in communal life, but never that of a gymnasium. It housed the bureau of the communal administration, the office of the Russian Zionist weekly, the head-quarters of the Zionist society, a labour exchange and a poste restante, besides two separate schools whose classes foregathered in shifts. It was also within its walls that I delivered two addresses on the purpose of my mission. The first was given on a Sunday afternoon, at a private meeting of representatives of all the Jewish organizations, institutions and parties in the city, and as the speeches of welcome which they all pronounced were mostly in Russian, which I understood little more than Chinese, I had ample time to meditate on my reply. Red-bearded Reb Yossel was also there, representing, as he said, the unorganized members of the community. The Poalei Zion representative, speaking in Yiddish, delivered a very vehement tirade against the Allies for maintaining the blockade and appealed to me fervently to use my influence with the British Cabinet and the Peace Conference to get it raised. I was made to feel even more important than when I was invited by the Shammash to act as Maggid. ${ }^{1}$ I disclaimed all influence either in the British Cabinet or in the Allied Councils and devoted myself to a faithful account of all the events that had led up to the San Remo decision. In the middle of my narrative the electric lights suddenly went out, and Reb Yossel exclaimed in Hebrew: "Let there be light !" Somebody went out to fetch a candle, but as it was doubtful when he would return I continued my address in the dark. It was an eerie experience to speak to a roomful of people who were utterly invisible except for the transitory glimmer of a few faces hazily illumined by the red glow of cigarettes. I spoke in the darkness fully ten minutes before a flickering candle was brought

1 Preachor. 
in, which Reb Yossel greeted gutturally with "And. there was light!"

The second occasion was the opening of a Palestinian Conference, to which delegates had come from Shanghai and Tientsin, from Chita and Vladivostok, and from one or two other places. The large hall was crammed with an expectant multitude, brimful of excitement and overflowing with comment. The air was thick and hot with human breath and cigarette smoke, and the long windows streamed with perspiration. Greetings and good wishes to the Conference were offered in enthusiastic speeches which struck some particular party note, and all went well until I rose to deliver my own little speech, which I intended to be of a quite neutral character. But I had no sooner uttered a few Hebrew words than the Chinese police official rose from the front row and demanded that I should speak Russian. A Chinese policeman demanding that an English-born emissary should speak Russian at a Zionist Conference on Palestine! This was, indeed, a novel situation. The chairman explained that I could not speak Russian and that he had obtained special permission for me to use any tongue that I chose. The official retorted that he had no information about this, whereupon the chairman suggested that he could inquire of his superior on the telephone. The dutiful functionary promptly accepted the suggestion and elbowed his way through the throng to seek a telephone below. I continued my speech in German and had just concluded amid cheers when the Chinaman returned with a smile. Whether he received confirmation of the chairman's statement was doubtful, as there was apparently a plurality of police authorities, with a diversity of jurisdiction.

The subsequent proceedings of the Conference were dogged by an unkindly fate, for when the delegates met the next morning they were informed by a police official that the meeting was forbidden. I drove post-haste in a rickety droshky, drawn by frost-covered Mongolian ponies, to the British Consul, who was kindness personi- 
I7.6 THE JOURNAL OF A JEWISH TRAVELLER

fied. There was some violent telephoning to some Lord High Mandarin, followed by expostulations, explanations and apologies, and the Consul assured me that all would now be well. The Conference was resumed, with the policeman in attendance, but its practical purposethe consideration of measures for the establishment of a Palestine Information Bureau to serve the whole of Siberia and for the selection of suitable settlers-was obscured for hours by a heated discussion on technical formalities. Two of the delegates had travelled many days, partly on foot, and braved many dangers. They were big, brawny men, redolent of the Mongolian steppes, from the neighbourhood of Urga, and they told a sad tale of the atrocities against Jews committed by the troops of that Baltic brigand, Baron Ungern-Sternberg, who terrorized vast regions until he fell into the hands of the Bolsheviks and then ceased from troubling for evermore.

The dominating figure of the Conference was a youngish man, Mr. Evseroff, who had been a successful lawyer in Petrograd until the-advent of Lenin. Then, seeing that liberty in Russia was doomed and that he could no longer work for Palestine until he had shaken off the shackles of the Soviets, he contrived to secure an important position as a Commissary, had himself sent on a confidential mission to some remote place near the frontier, and at the earliest opportunity slipped through the Bolshevik cordon. He was a dynamic force of almost inexhaustible energy - a capable organizer, an eloquent speaker and a gifted journalist. His work had been doubled through the absence of the former chairman, Dr. Kaufmann, who had been recruited by Koltchak for the benefit of his troops' health and was now detained by the Chinese at Urga in a sort of quarantine. He was the editor of the Russian Zionist weekly, SiberiaPalestine, which was smuggled through the Soviet frontier and brought hope and healing to hundreds of Jewish communities. He worked through the night 
until four in the morning four times a week, dictating translations to weary writers from English and German Jewish papers for the columns of his journal, which he had mostly to fill himself. But he had burnt the midnight oil too much, and during my week's visit he collapsed with mental prostration. I saw him in bed one evening in his humble lodging, a cold bandage on his forehead, and the lamp darkly shaded. The doctor had ordered him complete rest, but on the table were proof-sheets which he had corrected for the next issue.

"What does it matter if the paper doesn't appear for once, or if its publication is postponed for a few days ?" I urged in friendly reproof.

"We cannot disappoint our thousands of readers," came the stoic response in the editorial plural.

His virile young frame shook off the attack in a couple of days, and he returned to work with unabated spirit.

5

The material purpose of my visit was first broached at a select gathering in the house of Mr. Kagan, one of the wealthy members of the community, who was unfortunately away in Japan. It was attended by most of those who were reputed to be rich and generous, and it received a representative and even official character through the presence, not only of the Rabbis of Harbin and Chita, but also of the British Consul, Mr. Porter, and the Vice-Consul. Mr. Porter, from the moment of my first official call, had displayed keen sympathy with the object of my mission and was anxious to further it as well as he could. In the course of my stay he intervened effectively on behalf of a contingent of released Jewish prisoners-of-war who were travelling to Vladivostok, and whom a gang of "White" troops had threatened to waylay at an intermediate station. I also called upon the American Consul and invited him to attend, but although I told him of President Wilson's cordial approval of the Zionist ideal as well as of the 
I78 THE JOURNAL OF A JEWISH TRAVELLER

prominent part played by American Zionists in the movement, he seemed doubtful whether he could come without first consulting the American Minister at Peking, and as there was no time for this step he gave himself the benefit of the doubt and stayed at home. I addressed the gathering in three languages-five minutes in Hebrew, ten in English and fifteen in German, and when I sat down Mr. Porter humorously observed that he had been most impressed by the passionate periods in my German speech. Rabbi Kisselhoff, in the name of the community, thanked the Consul not only for his presence but also, as the representative of the British Government, for the anticipated blessings of the Balfour Declaration, and Mr. Porter responded with courtly dignity and then withdrew with his colleague.

We thereupon turned to the delicate but vital question of finance, and it was suggested that as the wealthiest member of the community, Mr. S. Skidelsky, was not present it would be unwise to start the list of donations on the spot, as the standard of generosity might be lowered. Some of those present, unmoved by this argument, signed their names for amounts of $£ 500$ and less, and Mr. Isaac Soskin (a brother of the well-known colonization expert, Dr. S. Soskin) and Mr. Drisin were appointed to collaborate with me in a lightning collecting campaign during the next few days. They were strenuous days but fruitful, for although we called only upon a dozen persons we received promises altogether for $£ 8000$. The list was headed by Mr. Skidelsky (who had only just given I00,000 dollars to the Chinese Famine Fund) with

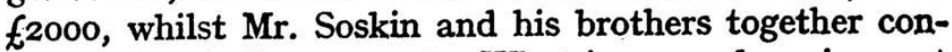
tributed a similar amount. What impressed me in most cases was not merely the generosity but the good nature and good wishes that accompanied its expression, for in other lands I had had much experience of donations given with such manifest reluctance that I felt like one who had drawn blood from a stone. A friend of Mr. Soskin, who promised $£ 600$, meekly apologized for not 
being able to give more owing to the prevalent depression. With such a spirit of good-will abounding, I felt sure that, had Russian Jewry not been overwhelmed and crushed by such a political and economic catastrophe, the $£ 25,000,000$ for which desperate appeals were being made to the Jews all over the world, and which the Zionist leaders wanted within five years, would have been offered by the Jews of Russia within five months. Unfortunately, even the million and a half of roubles which had been collected when the rouble was good by the Jews in Siberia for the Jewish National Fund, and had been retained in Harbin until the rouble became hopelessly bad, seemed not to possess the least prospect of appreciation.

Whilst I was busily engaged, day after day, on my financial forays, an incident occurred that seemed to have the element of the romantic or the melodramatic. On returning to my hotel early one evening I was told by the hall-porter that he had received a telephone message from somebody that a lady would wait for me outside the hotel at half-past eight. Neither name nor purpose was given, and as the message did not seem to me quite kosher I decided to ignore it, especially as I had an invitation to dine that evening with the Consul. So I told the porter that, if any lady called, he was to ask her to state her name and business. I mentioned the incident to the Consul at dinner, and he commended my discretion. He told me that the city was full of adyenturers of both sexes, and that one had to walk warily, especially when one, like myself, was supposed to be in possession of vast funds. The unknown lady might be a decoy for a band of robbers. When I returned to the hotel I ascertained that no lady had called, "for," said the porter, "the message said she would wait outside." As there were over twenty degrees of frost that night the "lady" must have not only cooled her heels but become unconscious that she had any.

But after very careful reflection I came to the con- 
clusion that there was probably no lady in the case at all, and that it was a ruse of Reb Yossel to secure the interview for which he had been repeatedly pestering me.

\section{6}

The final meeting was a rather impressive affair. It was held in the large hall of the Commercial Club, which had accommodation for only 700 , and all the tickets of admission were snapped up in a few hours. The inevitable Chinese policeman, with the inevitable smile, was again there, but I was allowed liberty of language as well as of speech. The meeting was announced for eight o'clock, I was told to be there at half-past eight, I arrived at a quarter to nine (for I thought I knew local habits), and I had to wait until nine o'clock before the chairman arrived and the bell signalled for the people to take their seats. I spoke in German, as the medium in which I could best make myself understood, and covered much the same ground as I had done in most of my previous public addresses, but with special reference to local conditions and expectations. At the conclusion of my speech the chairman, to my great astonishment, declared an interval, and the audience strolled out into the vestibule and refreshment-room, regaling themselves with criticism and tea. Glasses of tea were also brought to the platform, and ten minutes later the bell rang again as in a theatre and the audience trooped back to their seats. Mr. Evseroff, fully recovered, made a powerful speech, a torrent of eloquence pouring from his lips. The material response was satisfactory, for the total amount promised had reached $£$ ro,000. One of the contributors, I was told, was a Jew who had been baptized under the stress of Tsarist persecution, and who confided to a friend that he had never regretted that recreant act so bitterly as on that night. (Some time afterwards I learned that the total had increased by another $£ 2000$, half of which was promised by Mr. Kagan.)

After the meeting Reb Yossel met me in the vestibule. 
"Nu, will you take me to-morrow?" he asked eagerly. "I am quite ready. What time shall I meet you at the station ?"

Some friends rescued me from his unwelcome attentions and took me to the dining-room upstairs for a farewell supper. It was close upon midnight, but the hour was seasonable in Harbin. We were a convivial group, talking in various languages, and exchanging the experiences of various lands. One of my friends expounded an ingenious idea for raising the funds for Palestine: that every State should levy a special tax upon its Jewish subjects for the purpose, and that Great Britain-the Mandatory Power-should lead the way. He elaborated the idea with illustrations from the time when Polish Jewry had communal autonomy, and limned a glowing prospect of magic millions. In vain I told him that such legislation would mean the resurrection of medieval methods and was utterly impracticable; he fondly hugged the belief that he had conceived the only real solution of our financial problem.

Towards the end of the repast Mr. Soskin drank to the continued success of my tour and expressed the wish that the $f 25,000,000$ would be raised. Another friend voiced the hope that he would live to see $2,000,000$ Jews in Palestine. A matronly enthusiast, a mistress of Hebrew, trusted that we should soon cease to be divided by a babel of tongues and would all speak Hebrew. Still another friend expressed the wish that there would never be any more pogroms, and a fifth that Palestine would become as beautiful as Paradise.

"And what do you wish ?" they-all asked me.

"That all your wishes may be fulfilled," I said, " and in addition, that I may meet you all in Jerusalem and meet there also all the other friends I have made and shall make in all the lands of my tour, and bring you all together and make you known to each other, and thus forge that bond of brotherhood, which is the symbol of all Israel, in the land of Israel." 


\section{CHAPTER XXIII}

\section{TIENTSIN}

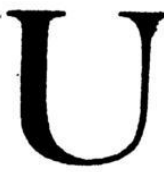

PON my return from Harbin I passed through Mukden again, early one morning. It was New Year's Day, and snow was falling heavily. As I sat in the railway restaurant eating porridge-proof of the penetration of English habits-I caught a glimpse through the window of another symbol of English culture : a glossy silk hat on the head of a high Japanese official who was driving in a closed carriage to offer congratulations to the Governor. My astonishment at the strange spectacle was cut short by the arrival of Mr. Herskowitz and his wife with my hat and coat, and I reluctantly parted with the warm Siberian apparel I had worn for the past week. Presently I was in the train once more, travelling in the direction of Tientsin. My compartment was poorly heated, and as the dining-car was small and draughty and most of its Chinese occupants alternately coughed and spat, I chose the lesser of two evils by remaining in my seat. Fortunately the sleeping-berth at night was broad and cosy, but I had to leave it betimes as the train thundered into Tientsin station the following morning at half-past six, when it was still dark. I was arranging with a porter for the transference of my luggage to an hotel when I was suddenly greeted by name. I had written to a local Jewish resident of my coming, but I did not expect anybody to meet me at that unearthly hour. Yet here were four Jews, strangers yet friends, who had turned out in the cold and darkness to offer me a fraternal welcome. I was touched by their kindness, and as we drove 
to the Astor House Hotel they told me that arrangements had been made for me to address a public meeting in the afternoon. One spoke English like an Englishman; the others had come from Russia.

"But is there a Jewish community here ?" I asked in surprise.

"There are almost enough Jews here for two communities," said one, " an English and a Russian congregation. There are probably three hundred Jewish souls here altogether, and we are raising a fund to build a synagogue."

At the hotel I was shown the North China Star with a quarter-page advertisement announcing that $I$ would speak at four o'clock in the Gordon Memorial Hall, so I felt assured; and as I had nothing else to do I decided to call upon the British Consul-General and invite him to the meeting, and then take a view of the city. The Consul-General, Mr. Kerr, was officially not at home, for it was Sunday, but he readily received me, asked me about my experiences and promised to come.

Tientsin is a large and up-to-date city, with broad thoroughfares, electric tramcars, modern houses, big public buildings and at least one fashionable European hotel-in short, a smaller edition of Shanghai. It is almost equally cosmopolitan, for it has nine foreign Settlements, whose areas are carefully delimited on the local map, though the Russian, German and AustroHungarian Settlements are now all designated with the prefix "ex." The creation during the last fifty years of these foreign Settlements, of which the British, covering 900 acres, is the largest, has provided a powerful impetus to the economic development of Tientsin, which is now the largest port in North China, though its harbour is ice-locked in the winter. The streets in the various concessions bear names in the respective languages and are reminiscent of the particular country to whose jurisdiction they belong. Thus, the principal thoroughfare in the British Settlement is Victoria Road, whilst conspicuous 
in the American area is Woodrow Wilson Street. The architecture of the residential neighbourhood, however, presents little diversity, most of the houses being of the large detached or semi-detached villa type, surrounded by gardens. As for the commercial quarters, they might be in any Western city but for the occasional Chinese signs on the shop fronts or the rickshaws driven past by the Celestial coolies.

I was accompanied on my round of sight-seeing by Mr. Max Dietrich, one of the gentlemen who met me in the morning. Despite his German name he had never been in Germany or Austria in all his life, nor could he speak more than a word or two of German. He was a curious instance of the Jew without a fatherland. He was born in Constantinople of a father born in Galicia, but he spent his childhood in Egypt and afterwards went out to China, where he made his home. At the outbreak of war he was technically an Austrian subject, but as he spoke only English, was employed by an important English firm, and had always been regarded as English, he enjoyed the protection of the British Consul. After the collapse of Austria and the embodiment of Galicia in the new Polish State, it was suggested to him that he could apply for recognition as a Polish subject and thus shake off the odium attaching to an ex-enemy subject. "But I had read too much of the Jews in Poland who have been killed by their fanatical fellow-citizens," said Mr. Dietrich, " to be disposed to present Poland with another citizen, even though I should never come within. the reach of the pogrom-makers. I want to become either a Jew or an Englishman."

"But a Jew you are," I rejoined.

"I mean a Jew politically and nationally, with a Jewish passport. Isn't that possible ?"

" Not yet," I replied, " though the Palestinian passport is in Hebrew as well as in English and Arabic. But to acquire Palestinian nationality you must qualify by residence in the country." 
"I'm afraid that isn't possible for me at present," he replied, "so I must try and get transferred to Hongkong, so as to qualify there for British papers."

On entering the native quarter we came into contact with a wedding procession. It consisted of about three dozen people, all gaudily arrayed in grotesque red costumes and shouting lustily, carrying picturesque banners inscribed with joyous greetings, and headed by a band which produced the most terrifying jangling din, punctuated by comical shrieks. In the middle was borne on the shoulders of hefty coolies an ornate palanquin, also painted red, in which the bride sat carefully concealed behind curtains; whilst the bridegroom was calmly awaiting his lady-love at the scene of the nuptial ceremony. Occasionally the procession got dispersed in the traffic, and this only added to the discord. The shops and stores were all open; the shopmen, with fingers interlaced on their breast, bade you a smiling welcome at every turn. We inspected some carpets and goatskin rugs, which are manufactured here in great quantities and sold very cheaply, and after concluding some purchases we returned to the hotel. We arrived in time to see a serenade that was being given at the entrance to the head of a prominent American firm which was a big employer of native labour: he was a guest at the hotel and was leaving later in the day. The serenaders, a group of military trumpeters and drummers, who wore woollen gloves against the cold, went through their musical exercises with deadly earnestness. They had with them a sort of portable cabinet, carried on two men's shoulders, from which the leader produced an elaborate scroll, doubtless inscribed with the most fervent wishes in the most florid terms, and took it into the hotel for presentation to the parting guest.

The Gordon Hall, in which my meeting took place, is an imposing stone edifice, adorned with turrets, in the British Settlement, which was built as a memorial to General Gordon and offered a safe asylum to hundreds 
I86 THE JOURNAL OF A JEWISH TRAVELLER

of foreigners during the Boxer Riots in I900. A great Union Jack was stretched across the wall at the upper end of the room, and two rows of children-boys and girls-wearing the Zionist colours and holding little Zionist flags, were drawn up at the opposite end, ready to sing Hatikvah under the direction of a teacher. The audience consisted mostly of Russian Jews, who had migrated across Siberia during the war, and were apparently in easy circumstances, whilst the rest comprised Bagdadi and American Jews and a few Christians. After the Hebrew anthem had been tunefully rendered by the children, I was introduced in English by Mr. Dietrich and in Russian by Mr. Gershevich, and then I delivered my address, partly in English and partly in German. A supplementary speech was given by a gentleman in Russian, and the British Consul-General supported my appeal and proposed a vote of thanks for my address. These polyglot proceedings concluded with the announcement of the subscription list, the contribution of Mr. Kerr being greeted with the greatest applause.

Upon returning to the hotel for tea I found that a the dansant was in full swing in the large dining-room, and I felt transported for the moment to some hotel in the Strand. There were many Jewish guests present whom I had not seen at the meeting, but I considerately refrained from spoiling their pleasure by soliciting donations. I could not help reflecting, however, how easily Jews could adapt themselves to any strange environment, for I was told that some of them had arrived from Siberia only a couple of months ago, and here they were jazzing away as though without a care in the world. In the evening I had dinner at the house of a Russian Jew, one of the many wholesale furriers in the city, and the meal, with its vodka, herring hors d'auvre, and beetroot soup, was entirely faithful to Russo-Jewish tradition.

The following morning I was taken by a friend to see another Russian Jew who had attended my meeting 

. 


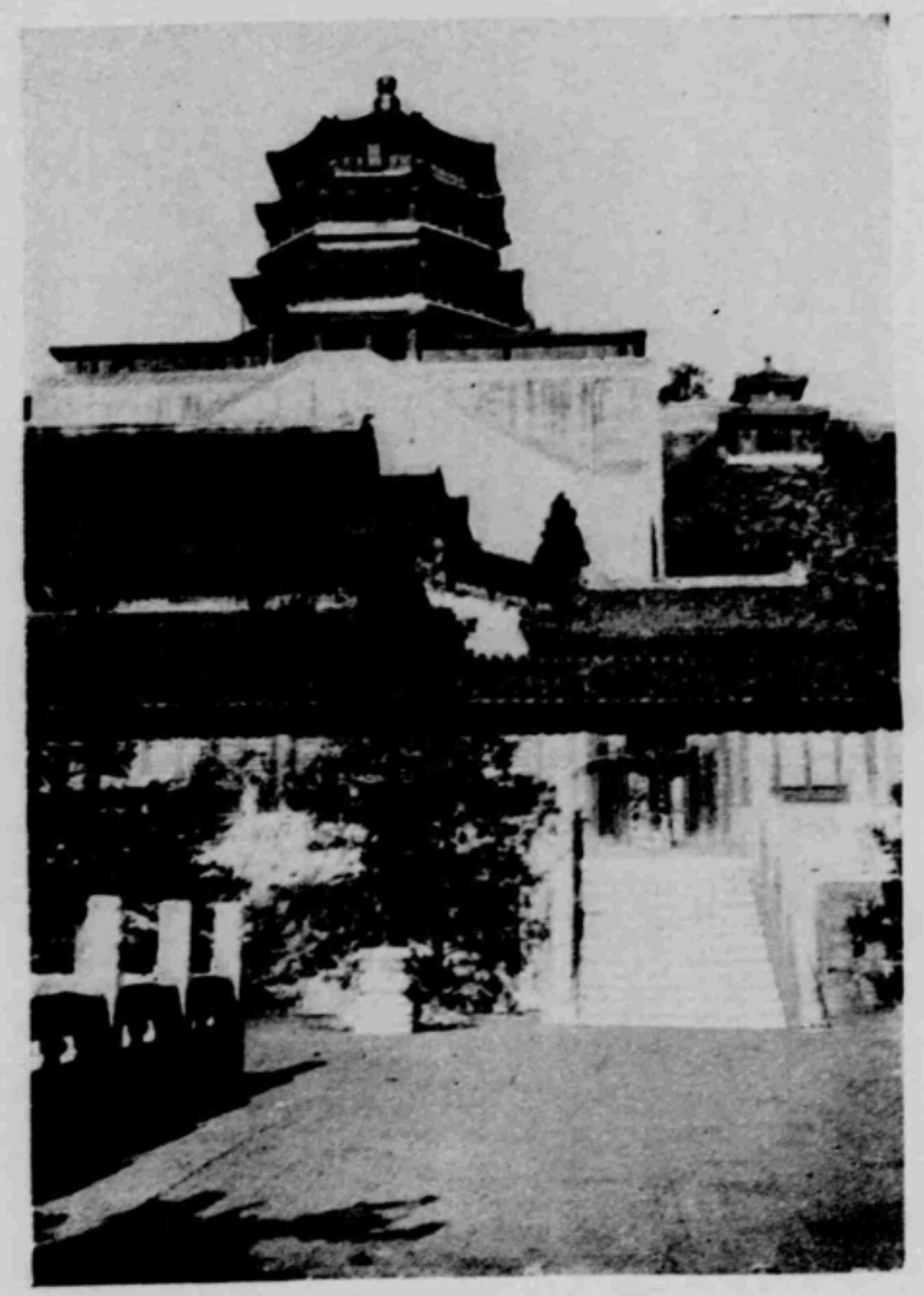

SUMMER PALACE, PEKING

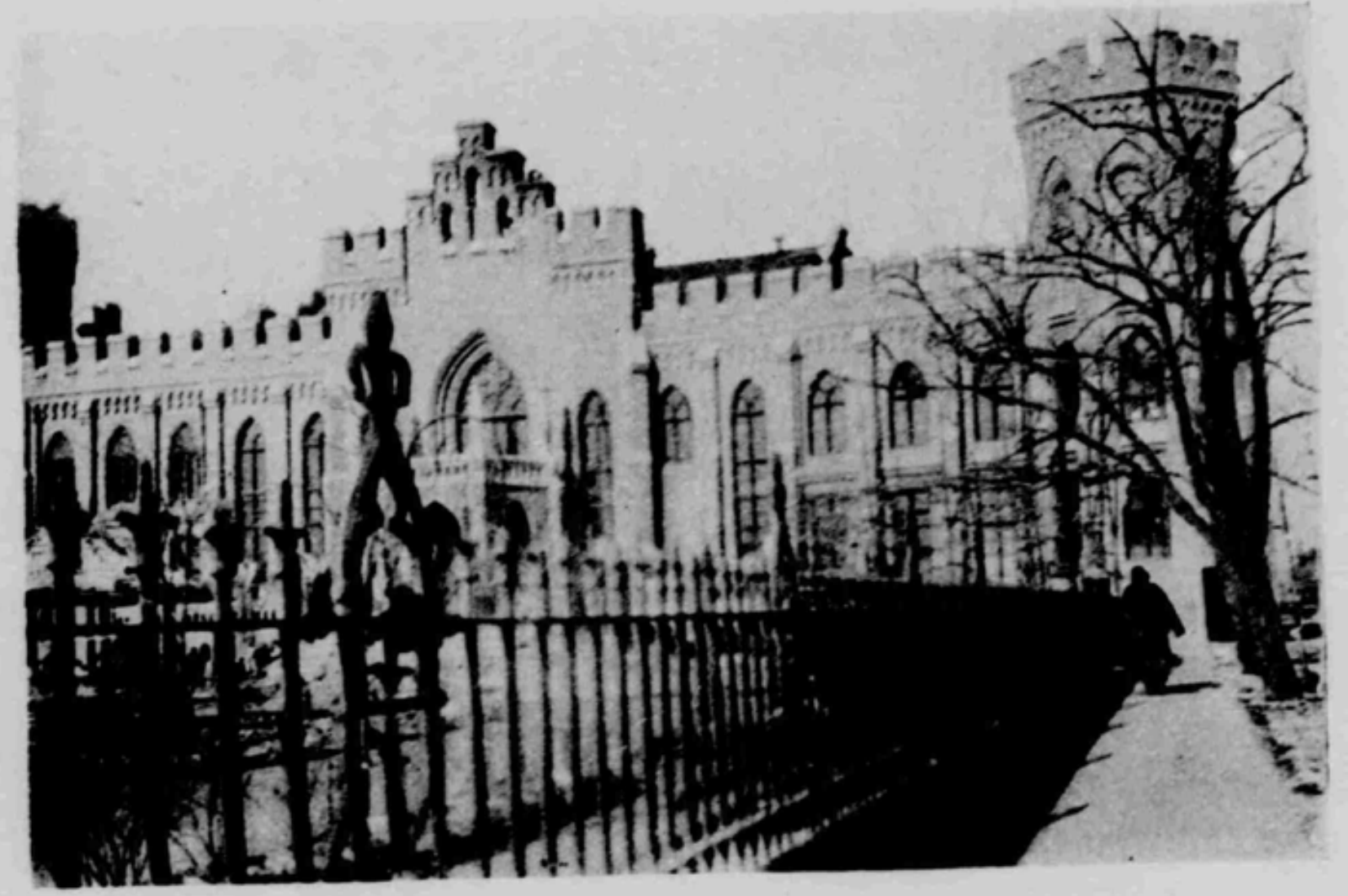

GORDON MEMORIAL HALL, TIENTSIN 
but who, though wealthy, had contributed nothing. We found him with some men in his office, which was filled with the smoke of Russian cigarettes. I was welcomed quite cordially and offered a cigarette, but this was the only gift that I received, for its wealthy donor at once proclaimed himself a Bundist and said that, as such, he could not " on principle" subscribe to the Zionist cause.

"Do you attend synagogue?" I asked.

" Sometimes," he replied.

"And don't you pray there for the restoration of Zion ?" I continued.

" Not particularly," he said. "Zion is not likely to be restored through my prayers."

"Quite true," I rejoined, " nor through your financial support either."

One of his friends maintained that it was much more important to send money for the relief of the sufferers of the pogroms in the Ukraine, but when I asked him how much he had sent, he pleaded the difficulty of ensuring that the money would reach its destination. Another man indulged in a violent denunciation of the Zionist Commission in Palestine.

"They are suppressing the Jewish language," he exclaimed excitedly.

" Nonsense," I retorted, "they are doing all they can to foster Hebrew as the national tongue."

"I don't mean that," he replied, waving his hands. "That's a reactionary tongue-the tongue of priests and theologians. I mean Yiddish-the only true Jewish Volkssprache, and that is suppressed and prohibited in Palestine."

"You are utterly mistaken," I said ; " there is complete liberty of language, though Hebrew and not Yiddish is an official language."

"Aha! There it is!" he cried, banging a desk. "Yiddish, the language of the people, is oppressed by the reactionary bourgeoisie in Palestine. No; I have lived for Yiddish and I shall die for it !" 
I88 THE JOURNAL OF A JEWISH TRAVELLER

"But not in China:," I calmly observed.

The temperature of the room had considerably risen during the last few moments, and as my quest was obviously doomed, my companion and I, after a mutual exchange of good wishes, withdrew in time to enable me to catch the afternoon train to Peking. 


\section{CHAPTER XXIV}

\section{PEKING}

TF ever I was impressed with the ubiquity of the Jew it was by an experience on the railway journey from Tientsin to Peking. In my compartment, 1 sitting opposite me, was a dark, middle-aged man, with a black moustache tinged with grey, spruce in appearance and melancholy in manner. For the first hour both of us were immersed in our papers and books, or glanced through the window to catch a glimpse of the Great Wall, without speaking a word to one another. Then he looked up and asked: "Quelle heure avez-vous, monsieur?" I answered him in the same language, and as I had hitherto found English to be the most widely spoken European tongue in the Far East, I concluded that he must be a Frenchman. After this overture we gradually approached a discussion of the complicated political problems of the Far East, and I saw that he was best informed of the conditions in Siberia. But he seemed reluctant to say anything that might throw light upon his own personality, and I began to wonder whether he might be a secret political agent. Just as we were nearing the Peking station, however, he grew more confidential and gave me his card, on which I read: "M. Israelski." I gave him mine in return, and as our eyes met we exchanged smiles and greeted one another with the time-honoured salutation: "Shalom Aleichem." He was a Russian Jewish mining engineer, and he was going to the same hotel for which I was bound, to meet one of my generous supporters of Harbin for a business consultation. 


\section{I9O THE JOURNAL OF A JEWISH TRAVELLER}

$I$ arrived in Peking at night, when it was almost impossible to see anything except the dancing lamps of the racing rickshaws or the grim lofty walls past which I was driven. Within the hotel, a new up-to-date European establishment, there was a scene of comfort and animation, replete with all the features of modern luxury, which would have made me completely forget I was in the capital of ancient Cathay were it not for the Chinese waiters or the books and pictures on sale at the bookstall. The spacious restaurant was an alluring spectacle of smartly dressed guests sitting at daintily decked tables illumined by coloured lamps; whilst from the red-coated orchestra in the sumptuous ballroom came the languorous strains of a Viennese opera, weaving a spell over the enraptured dancers.

But outside the hotel, when I set out next morning in a rickshaw to call upon the British Minister, I felt transported a few hundred years back. There was a sense of illimitable spaciousness everywhere, as though time did not matter; the roads were unusually broad and endlessly long, traversed by motor-cars and rickshaws, by trains of dromedaries with loads of coal, and by bearers of ornate palanquins with painted ladies; but the hum of traffic was subdued, as the city was innocent of electric tramcars. Far away in the distance, what seemed a thin line on the horizon was the wall that surrounded the entire city, measuring thirty miles in circumference. Soon we passed through one of the cavernous gateways of the massive square wall that encloses the Inner or Tartar. City, a gigantic fabric thirty-seven feet high and nearly twice as wide, and as I tried to measure these stupendous dimensions with my eye and gazed at the imposing buildings in the Legation quarter, I saw myself suddenly wheeled through a more ordinary gateway and received the smart salute of a "Tommy" in khaki. I was within the precincts of the British Legation, but I felt as if in a miniature fortified city, for all around was a massive stone wall, behind 
which sentries paced to and fro, and I caught a glimpse of a guard-room, and here and there of guns. Within these British walls were the residences of the Legation officials, intersected by avenues and walks, on which I passed an English nurse, clad in conventional grey garb, taking a child out for an airing.

I wished to see the Minister, Sir Beilby Alston, for the purpose of invoking his good offices in regard to three important matters with which I had been entrusted by my friends in Harbin. The first and most urgent was to obtain the release of Dr. Kaufmann, the Chairman of the Harbin Zionist Association, from his enforced detention at Urga ; the second was to secure for the Jews in Harbin the right to hold their Zionist meetings without police restrictions ; and the third was to render it possible for those Jewish prisoners-of-war who were being repatriated from Vladivostok and who wished to go to Palestine, to disembark at Port Said, so that they could travel by train to Jerusalem. Sir Beilby gave me a cordial welcome, and was greatly interested in my three requests, especially as they were very much different in kind from those usually made of the British Minister at Peking. He promised to make immediate representations to the Chinese Government on behalf of Dr. Kaufmann, whose return, I urged, was essential not only for the happiness of his wife and family but also for the welfare of the Jewish community. He also promised to do what he could in regard to the liberation of Zionist meetings from capricious regulations, and undertook to cable to London for instructions respecting the returning prisonersof-war. He asked me various questions concerning the course of my tour and the developments in Palestine, and closed the interview with an expression of good wishes for the continuance of my mission. Subsequently I learned that Sir Beilby's representations on behalf of Dr. Kaufmann were immediately successful, and that there were rejoicings in the Harbin community when the long-absent leader came home. 
The only other personal visit that I paid in Peking was to a Russian Jew, whose name had been given to me in Tientsin. It was Mr. L. S. Regine, whom I found living in a flat in a block of buildings bearing his own name, which he had erected not far from the British Legation. My visit took him by surprise, for it was not often that a Jew from London called upon him. Fortunately he had read an account of my mission in the Tientsin paper, so that I was spared an explanatory introduction. He was a middle-aged man, who had settled in Peking twelve years before and, after an initial struggle, had prospered. He had been the first to start the publication here of an English newspaper, the Peking Post, of which he was both owner and editor; but the paper was born before its time and expired very soon. He had perpetuated his name in this ancient capital, however, in another manner : by the presentation to the Central Park of the Regine Fountain.

Unhappily the rigour of the winter had affected his health, so he was unable to conduct me round the city. At his suggestion I first went to see the Temple of Heaven, accompanied by his native "boy." We drove in a car through the Inner City, which contains the foreign Legations, barracks, post-offices, banks and shops, past the great wall that encloses the old Imperial City, a region of several square miles containing the Purple Forbidden Palace (no longer tenanted by the Imperial Family), with its lakes, parks and artificial mound. Presently we passed through one of the sixteen gates, which are each protected by a semi-circular enclosure and surrounded by a tower perforated with innumerable loopholes, and as we sped along through the Outer or Chinese City I saw at intervals along the wide thoroughfare rectangular red-painted arches of tremendous height, in comparison with which the Arc de Triomphe was a modest goal-post and the Marble Arch a mere midget. Then we traversed a busy and insalubrious quarter, where the streets were lined with a medley of shops-here stores 
of mouldy curios in bronze, of rare porcelain, ivory figures, cups of jade and lamps of red-lacquered wood, and there a row of unsavoury stalls, where slaughtered cats and fried rats and divers undistinguishable pieces of meat were offered for sale, and little fat cakes of dubious ingredients were frizzled in spluttering pans.

At last we reached what appeared the open country, with miles of park covered with snow, and here and there the stately silhouette of a distant pagoda, though further still was the great encircling belt of blackened brick. And then looming ahead I saw the bell-shaped pinnacle of the Temple of Heaven, where the Emperor used to offer up prayers on important occasions. It is a shrine of majestic and monumental proportions, built 500 years ago, and enclosed within a wall three miles in circumference. It is a colossal circular edifice in three tiers, with three concentric roofs, adorned with a band of jade below each eave, and rising above a triple circular marble terrace, over 200 feet wide, to a height of several hundred feet. Its symmetrical bulk dominates the landscape for miles with its awe-inspiring grandeur. It has nothing of the grotesque or the bizarre: its exterior is more impressive than the interior of St. Peter's in Rome, for it produces its effect more directly, instantaneously, beneath the canopy of Heaven itself, so that all who gaze at it are hushed into a feeling of helplessness and dwarfed into mere atoms. The immensity of the conception makes the brain reel and inspires a boundless admiration for the Chinese architects and artists of five centuries ago.

Throughout my return journey the majestic fabric held my mind in thrall. When I saw Mr. Regine again he asked me what I thought of it.

"I often go to look at it," he said. "I know nothing like it and can imagine nothing like it. You will see more magnificent things in Peking, like the Summer Palace, with its villas, pagodas and marble boat; but nothing so impressive. Merely to gaze at it makes me feel a better 
I94 THE JOURNAL OF A JEWISH TRAVELLER man, a more devout man. Of what value is prayer beside the thoughts and feelings that it arouses ?" Then, after a moment, he added: "I don't know whether I shall ever see Erez Israel, but there is nothing that I would so much wish as that our Temple should be as beautiful and majestic as the Temple of Heaven." 


\section{CHAPTER XXV}

\section{THE STRAITS SETTLEMENTS}

I

FTER completing my mission in the northern
half of the Far East I turned my face south-
wards towards Singapore, whither I travelled
from Shanghai in two stages. On the voyage to Hongkong I sailed on a cargo vessel, for to have waited for a larger and more comfortable ship would have meant a delay that I could ill afford. The irksomeness of the surroundings was compensated for by the quietude, for which I was grateful; and there was even a rural atmosphere suggested by the bleating on the lower deck of a drove of sheep and goats, one or two of which perished of the cold each night and were flung into the sea the following morning.

My cabin companion was an American mining geologist, who read French detective stories and smoked cigars all day. He had had a varied experience in California and Alaska, in Mexico and South Africa, and he told me that he would like to get a concession to drill for oil in Palestine, where he felt sure that he.would find some. Our discussion about the Holy Land reminded him of a peculiar experience that had befallen an American colleague of his. The latter was prospecting in Mexico, when, owing to the political disturbances that are wont to happen in that country, he was thrown into prison, where the only reading that he was allowed was the Spanish Bible. He read therein of the magnificence of King Solomon's Temple, concluded that gold could still be found near Mount Sinai, and from the gloom of his 
I96 THE JOURNAL OF A JEWISH TRAVELLER

little cell had a vision of a glorious future. Upon his release he returned to New York, where he got a commission to go to Mount Sinai to search for gold. But his quest was fruitless, and so, after a few months, he began to wend his way homewards again. Whilst in Salonica, he heard that there was copper to be found in Cyprus. He therefore took the first ship to that island, and was rewarded by the discovery of large copper deposits, from which he soon realized the fortune of which he had dreamed in his Mexican prison.

My companion was now bound for some remote spot in the province of Kwang-tung, where he hoped to unearth a gold mine. He was to be accompanied by a detachment of 200 native soldiers for his personal protection, and also by a couple of mules laden with sacks of silver dollars for the expenses of the adventure. Now and again he would put aside his French romance and study a phrase-book of the Chinese tongue, with which he already showed a greater familiarity than did our captain and chief engineer, both Devonians, who had sailed the Chinese seas for twenty-three years and had neither lost their native accent nor acquired the local speech.

From Hongkong, after a brief and instructive excursion to Canton and Macao, I continued the voyage to Singapore -a pleasant five-day trip-on the P. and O. Plassy, a large though not very comfortable liner, thronged with English folk of all ages returning home. The lifting of our anchor was signalized by the firing of Chinese crackers as a farewell greeting from a launch that had brought us a distinguished passenger. On board I met a Jewish commercial traveller from London, whom I had previously seen in Tientsin: he had been roaming regularly for the last twenty years throughout Australasia and the Far East, and I gleaned from him some curious facts about the communities that I was visiting. My table neighbours in the dining saloon were a missionary and his wife, who regaled us with stories of the South Sea Islands, 
which they had toured in a private steamship of the Church of England Missionary Society. Their strangest story was of Ellis Island, where there were no men, but only women and girls, the principal institution being a girls' high school, reminiscent of the college in Tennyson's Princess. The missionary's wife introduced me to a fellow-missionary, Miss Coddrington, who had worked for thirty years in China, mostly at Honan, which is not far from Kai-Feng, the home of the now defunct Jewish colony. I thought that she might have been able to throw fresh light upon the declining days of that settlement, but her knowledge of its vicissitudes was less than my own. She told me that the Chinese were keenly interested in the return of the Jews to Palestine, and would be glad to hear that she had met me.

There was a perceptible rise of the temperature daily as we came within sight of the Malay Peninsula and I neared the equator for the third time; and on the morning of our arrival in the placid waters of Singapore Harbour, beneath a cloudless blue sky, everybody, both on land and on board, was wearing whites and topee. Three members of the Jewish community came on deck to welcome me, and one of them was welcomed by me in return with even greater warmth, for he brought me a batch of letters from home.

The hotel to which I was driven was altogether different, both externally and internally, from all the hotels in which I had ever stayed. A verandah ran right round the ground floor, so that one could walk straight from the street into the middle of the restaurant, without passing through any door; there were no windows, but shutters, which were up all day and let down at closing time, thus always ensuring an abundance of fresh air, which was kept in motion by large electric fans. My bedroom on the second floor was approached through a small sitting-room, which was divided from the broad verandah running the whole length of the floor only by a low balustrade and a skimpy hanging. The bed was 


\section{I98 THE JOURNAL OF A JEWISH TRAVELLER}

like a big snow-white cage, closed in on all sides and overhead by a mosquito-curtain, beneath which one had to dive quickly and dexterously; but there was no covering, as the tropical temperature made one superfluous. The bathroom, with its stone floor, consisted simply of a tub from which one drew water that was never quite cold in a little bucket or "dipper" wherewith to splash oneself whilst standing like Adam of old upon a little board-an operation that was necessary at least twice a day to counteract the enervating effects of the atmosphere.

Jews first began to migrate to Singapore in I840, from Bagdad and India, in the wake of the pioneering Sassoons. They assembled for worship in a house, near the business quarter, in a street which acquired and has retained to this day the name of Synagogue Street. Nearly forty years later there was built and consecrated the first Jewish house of prayer, facing west like all the synagogues of the East, wherein the Bagdad ritual was adopted and is maintained. The community gradually received accessions from Germany and Russia, but it continued-with its 600 souls in all-to be of a predominantly Eastern character. As I entered the synagogue I passed on the steps of the porch a grey-bearded man, with fez on his head, sitting barefooted and chanting psalms for the repose of some pious benefactor. Within I saw the Hazan intently rehearsing the cantillation of the next Sabbath's portion of the Law. For him Bagdad was still his spiritual home, for though he had spent fourteen years in this thriving British colony he could not yet speak a word of English. The Ark was richly endowed, containing twenty-four scrolls of the Law, all enclosed in conical cases of beaten silver from Bagdad ; but most of the members of the congregation seldom saw any of them except on the two or three most solemn days of the year. On the cases of some of the presented scrolls 
was the Hebrew name of Elijah intentionally spelt so as to avoid the transcription of the Tetragrammaton. Suspended from a network of wires stretching overhead from one wall to the other were many glass bowls with oil-wicks burning either during the first year after somebody's death or upon its anniversary : a display that was greatly increased on the Day of Atonement, when, I was told, there would be a few hundred of such hanging lamps shedding their faint beams upon the penitent worshippers. The piety that had prompted the erection of the shrine seemed to have evaporated in the ensuing decades, for the Sabbath attendance was reported to be meagre, and there had been no meeting of the congregation to discuss its affairs for quite a number of years.

But there was another and larger synagogue in a better part of the city. It was built some twenty years ago by the leading member of the community, Mr. Menasseh Meyer, who was reputed to be the richest Jew not only in Singapore but in the whole of the Far East. Its origin was due to a certain difference which its founder had had with the devotees of the older shrine-a social phenomenon that is just as apt to occur in equatorial regions as in colder climes. Born in Bagdad, Mr. Meyer had settled in Singapore in the early period of its development, prospered greatly in trade and was commonly said to own half of the property in the colony. True to the traditions of his pious forefathers, he maintained a degree of conformity with the principles and practices of his faith, which was not only conspicuous in itself but rarely seen in contiguity with such wealth. He had created a patriarchal domain that was typically Eastern in character, his synagogue being situated only a few yards away from his house. The latter, sprawling over the summit of a grassy slope, was a large white palatial residence, from which extended ample wings, including outhouses with horses and motor-cars, sheds with kine and cattle, and a well-stocked poultry-yard, the whole embowered in an evergreen framework of tropical vegeta- 
tion. There he lived, active and alert despite his grey. hairs and seventy years, with his sons and daughters, his sons-in-law and daughter-in-law, and three adopted orphan children. There was a Bagdadi Shochet in the house for the slaughter of plump birds ; milk of unimpeachable Kashruth was obtained from the domestic dairy ; and an orthodox chef ruled in the kitchen.

Mr. Meyer, wearing a black skull-cap, and seated in an arm-chair, with a book of Hebrew lore on a little table before him, awaited me in the covered porch that led to the main entrance of the house. He gave me a cordial greeting and asked after the peace of Erez Israel. $\mathrm{He}$ had been to Palestine the previous year with his daughter, and maintained there a Beth Hamidrash' ${ }^{1}$ and small synagogue for Bagdad Jews, so that he had already had an opportunity to form his own views about the conditions in the country. He told me that he had recently received letters from Sephardi Jews in Safed and Jerusalem, who complained that house-rents had gone up since the arrival of the Zionist Commission. I replied that house-rents had also increased in England, and that the Zionist Commission was not more responsible for the one than for the other. He also said that the letter-writers complained that the Zionist Commission discriminated against the Sephardim, a charge that I disproved, stigmatizing it as a fable devised for luring alms from distant and unsuspecting benefactors.

The following morning, being the Sabbath, a Jewish manservant of Mr. Meyer called at seven o'clock with rickshaws driven by Chinese coolies to take me to his synagogue, which was situated at a considerable distance from my hotel. Local custom had sanctioned the use of the rickshaw on the day of rest, and there was no Rabbi or Haham to question its rightfulness. On our way to the house of prayer the manservant told me that Mr. Meyer, in order to ensure a complete congregation at every service, engaged a number of Minyan men to

1 House of study. 



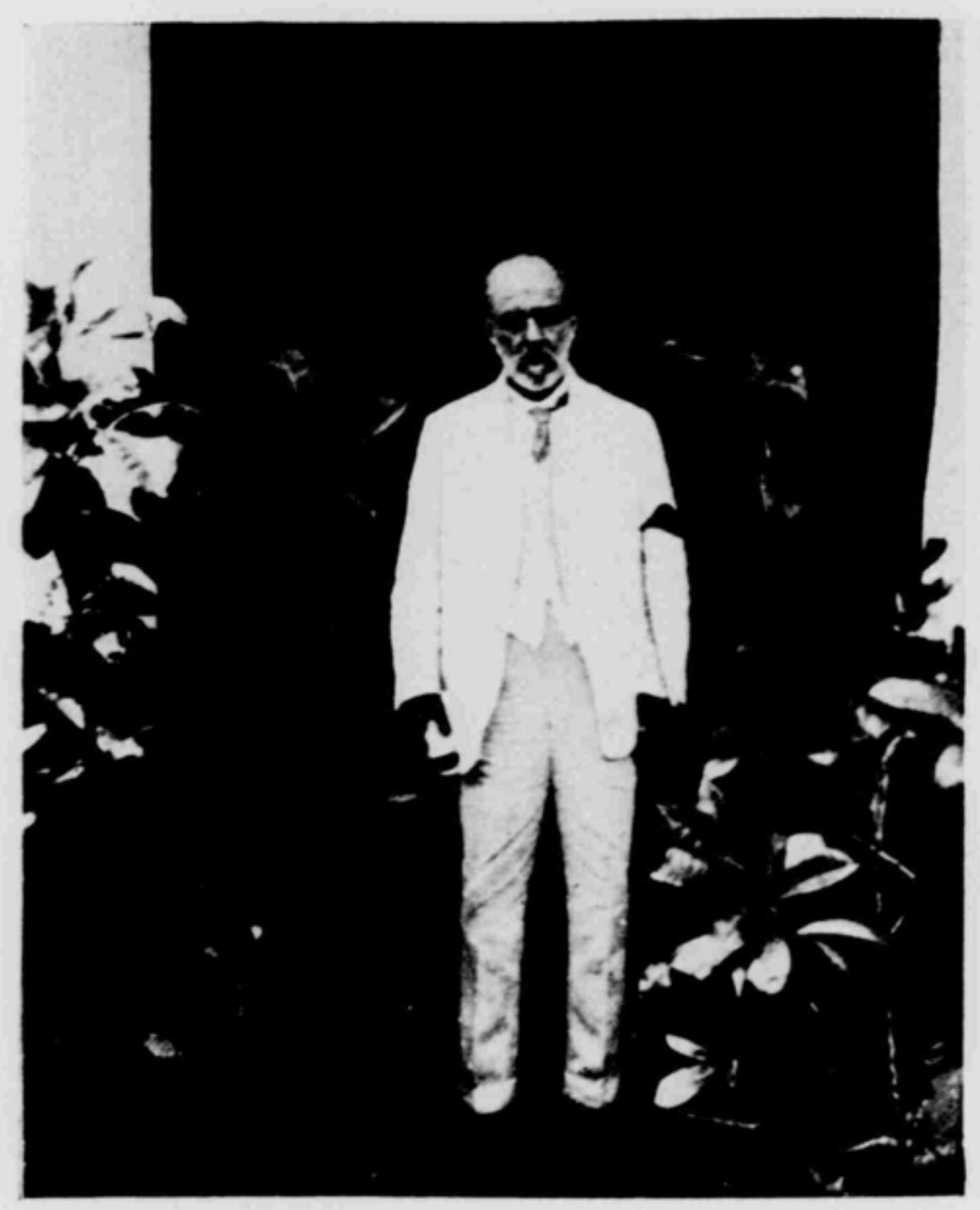

MR. MENASSEH MEYER, SINGAPORE

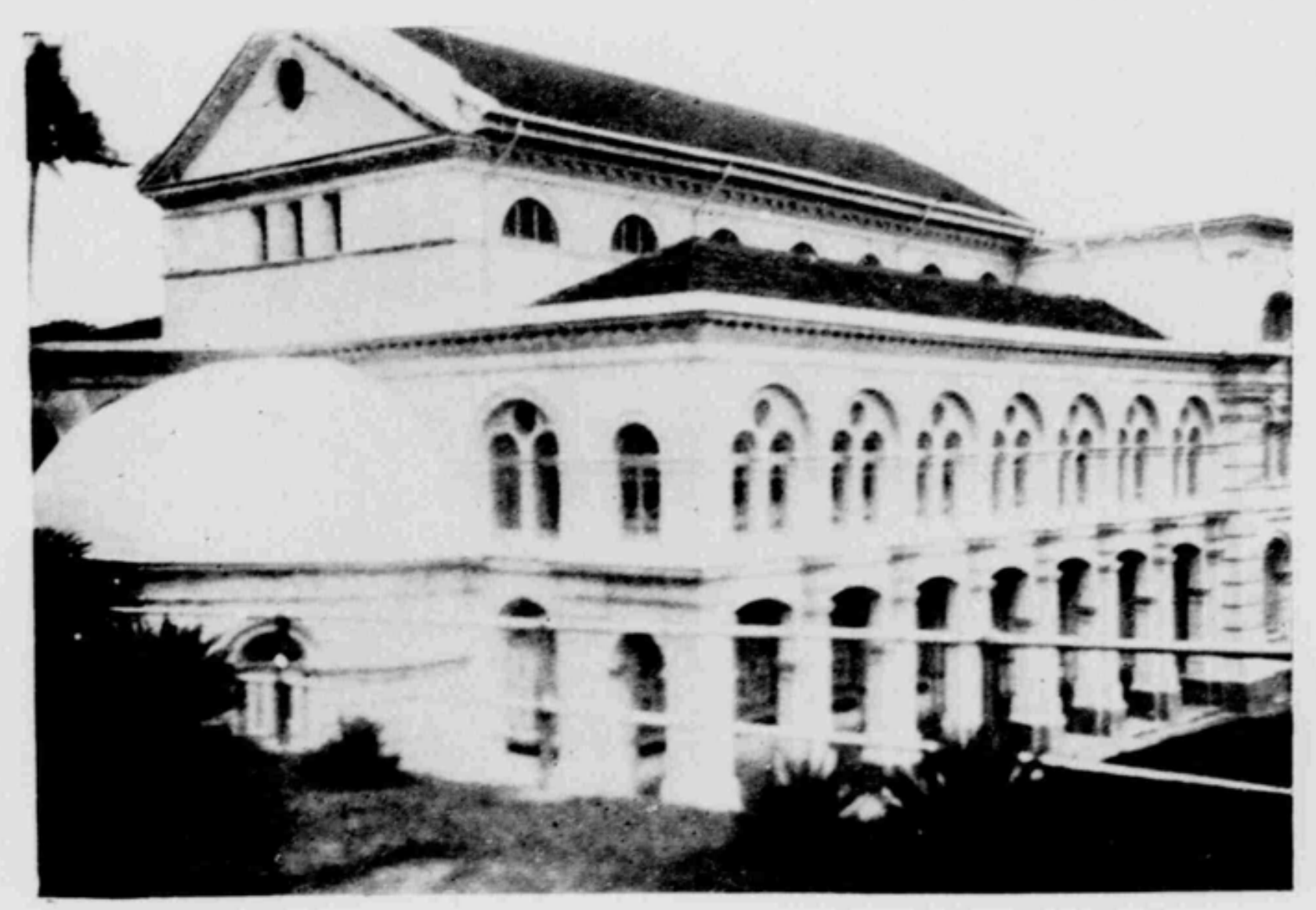

MR. MEYER'S SYNAGOGUE 

attend regularly, and even gave them a rickshaw allowance; but owing to the higher cost of living they had once gone on strike to obtain an increase of their emoluments, and the demand was gratified-probably as much in the spiritual interests of the congregation as a whole as in the material interests of the strikers. On another. occasion, one of the stipendiary worshippers demanded his carriage allowance for a full year in advance, in order to enable him to set up in business on his own account; but as there was no guarantee that he would faithfully fulfil his part of the contract, and as no Minyan man was ever known actually to use a rickshaw, the request was rejected.

The synagogue was a large, cream-coloured stucco fabric, with the Hebrew name "Hesed-El" gleaming aloft in gold letters on three sides. It was lofty and spacious within, and the air was kept cool by electric fans overhead. About twenty persons were present, Mr. Meyer occupying a special arm-chair in a sort of semi-enclosure, where all the male members of his family also sat. The grey-bearded Hazan, who wore a fez and striped linen gaberdine with girdle, gabbled away at a rate and in an accent that made it difficult for me to follow. After taking the Sepher out of the Ark he at once unrolled it, a boy pointed to the beginning of the day's portion with a silver pointer, and then the scroll was rolled up again and carried to the Almemar. The Hazan alone presided over the reading of the Law, without the support of any Segan or lay official ; and I was given a double call of honour, being summoned as Cohen and remaining also as Levi. When the service was over I was shown the scrolls in the Ark: there were about twelve altogether, in large silver-covered cases, and all from Bagdad.

I breakfasted with Mr. Meyer, who presided at the head of a long table, around which were grouped the members of his family and the orphan wards. A Chinese servant came round with an ewer of water and a per- 
forated basin for us to wash our hands ; the host uttered. the benediction over a large, flat spongy loaf (like that I. had seen in Shanghai) and distributed pieces among us; and a Bagdadi servant, wearing a black cap, waited at table. When the meal was over Mr. Meyer retired with the two fatherless boys to another room, where, in pious conformity with traditional custom, he began to hear them cantillate the day's portion of the Law.

\section{3}

The following afternoon, in response to a general invitation published in the local papers, the members of the Jewish community flocked to Mr. Meyer's house to listen to my appeal. The meeting was held in a very large drawing-room, liberally furnished with cosy chairs and little tables, and at one end a Zionist flag that I intended leaving as a memento hung conspicuously over a stupendous gilt-framed mirror. The whole of the adult Jewish population, about 250 persons, were assembled, regaling themselves with an appetizing tea, which was calculated to induce a benevolent frame of mind. There were present even two or three prominent members, who, owing to the heavy slump in their tin and rubber properties, had expressed a decided preference for the restoration of Zion by the gratuitous method of the Messiah. Close attention was shown by all alike to my address, nor was aught lacking in the vigour of the applause that marked its conclusion, and thereupon everybody's eyes were fixed intently upon our host, who was naturally expected to lead off in the financial response. Mr. Meyer had made some notable public gifts in recent years, including an aeroplane to the Colonial Government's war munitions and a substantial benefaction to Raffles College, and hence speculation was rife as to the extent of the bounty he would display on this momentous occasion. And so when, after a little suspense, I announced that it was to be 25,000 dollars (Mexican), that is, about $£ 3000$, and added that this was the largest 
individual gift that I had hitherto received on the whole: of my tour, the plaudits of the gathering were enthusiastic beyond measure.

The whole of the remaining response, including the sums obtained in the ensuing week's personal campaign, did not exceed $£ 2000$; but, even so, that total represented a high average for the small community, especially as $£ 2000$ had been raised for the Jewish National Fund only a few months before. One of the principal contributors to the latter Fund confided to me that shortly after he had given his donation he had unexpectedly earned more than twice as much on a business transaction (a profit exceeding $f_{1000}$ ), whilst others who had given. nothing lost heavily. "Is that not the finger of God ?". he asked me in an awe-stricken whisper. As I visited the offices and counting-houses of the Jewish merchants in the neighbourhood of Raffles Square I had to engage in occasional argument to coax a reluctant sympathizer. Some had been very sorely hit by the prevailing slump, and contributed scrip instead of cash. A Russian Jew upon whom I called in his shop took counsel of his wife, who, little suspecting that I knew Yiddish, said to her consort: "Gieb ihm zwanzig!" "Was ist zwanzig?" I protested. And they were at once both so nonplussed and so gratified to find that I spoke their tongue that they increased their gift to fifty dollars.

On the whole, the attitude of the community was marked by sympathy and generosity, in which even a Chinese company director and an Armenian hotel proprietor actively shared; nor were the malign efforts of a Russo-Jewish diamond merchant from Antwerp, who was on his way to sell jewels to the Court of Siam, and who boasted of his knowledge of Rashi ${ }^{1}$ and the Gemara $^{2}$ whilst condemning the ideals of Zionism, of any avail. It was, however, a matter of no little disappoint-

1 Mediæval commentator on the Bible and the Talmud, so named after his initials, Rabbi Shelomo Itzhaki (I040-1 I05).

The Talmud. 
ment that a meeting convened for the purpose of explaining the movement to the general public, and over which Sir William Murison, the Acting Colonial Secretary, presided, was, apart from members of the Jewish community, attended only by two or three Christians and two Chinamen-one of the latter being a member of the Legislative Council. This absence of the local British colony was partly attributable to the rival attractions of the festivities held in honour of the visit that week of the Malaya, the warship presented by British Malaya to the Imperial Government ; but it was doubtless also due to the general attitude of racial superiority assumed by the British Christians of Singapore towards their Jewish fellow-citizens, although the financial support of the latter was always sought in all local causes.

I enjoyed no lack of hospitality in houses replete with comfort, situated in scenes of luxuriant verdure. The patriarchal regime of the Meyer household-parallels to which I had already observed in the Jewries of Chinahad more than one counterpart in a matriarchal regime, embodying the unity and solidarity of the Jewish family. It was a feature of social life that had been transplanted from Bagdad, together with the Arabic tongue that was widely spoken by Singapore Jewry, and the hookah which was smoked with dignity by venerable Jewish matrons. Even if a man wanted a wife, he would sometimes make the long and costly journey to Mesopotamia to seek her, though his quest was not always successful. I was told the story of a local Jew who, having had no child after several years of marriage, went to Bagdad and brought back another wife; but she led him such a terrible dance that he decided to pack her off home again, and then lived happily with his first wife once again.

Between the Bagdadi and the Ashkenazi elements there was a certain subdued antipathy, which found expression more often in the first than in the second 
generations, and which was due as much to difference of colour as of provenance, with its complex corollary of mental factors. One of the most prominent members of the Ashkenazi section was a Russian Jew, who had begun life in the colony thirty-five years before as a humble pedlar, then turned carpenter, and after developing into a prosperous cabinet manufacturer also became the owner of many houses and shops and of a large coconut plantation. He surveyed his possessions wistfully one day as he showed me round his estate and then fervently said: "It is very pleasant here. But some day I shall sell everything and go with my family to settle in Erez Israel." Another Ashkenazi, the most ardent Zionist in the colony, was a native of East Prussia, who married a wife from Bulgaria in Melbourne, and had a son born in Manila. Such are the wanderings of the children of Israel.

What the community seriously lacked was a spiritual leader and, even more, a modern educated Hebrew teacher. The only arrangement for the Hebrew and religious instruction of the young consisted of a Talmud Torah that had been built by Mr. Menasseh Meyer, and which was maintained from the rent of some neighbouring shops. The school was approached from a narrow lane, on either side of which ran a gutter. It consisted of one large chamber, with tiled floor and whitewashed walls, containing in the middle four benches inscribed with the names of the donors in gilt Hebrew letters. Here some forty to fifty children of various ages and standards, and mostly poor, came to be initiated into Hebrew lore and the precepts and practices of Judaism at the hands of a single grey-bearded teacher, the Bagdad Hazan, in fez and white gaberdine; but how much they learned or understood it would be difficult to say, as their master, despite the many years he had been in Singapore, could not utter a word of English and spoke only Arabic, whilst the lessons were often distracted by the visits of a brood of chickens with their vigilant mother, which strutted 
206 THE JOURNAL OF A JEWISH TRAVELLER

from an adjoining yard into the room, leaving many an impression behind.

The gaberdined greybeard admitted that the children could not make much progress. "But what can you expect ?" he asked, with a shrug of the shoulders. He showed me a Hebrew book on the Sabbath laws, which he had received from Jerusalem. I thought that he was studying it, but he told me that he did not understand it and intended raffling it among the members of the community for his own benefit, to eke out his income. $\mathrm{He}$ had received some other Hebrew works from the Holy City, which neither he nor anybody else in the city could read, and which he likewise intended to dispose of by lottery.

The dispensing of charity was even in a worse plight than religious education. There was no committee or society to discharge that essential function of a community, and thus the poor went from house to house, and from office to office, seeking alms where they could, and free from the inquiry that might check their pauperization. An attempt had, indeed, once been made to establish a benevolent society, but as some of the founders had stipulated that the members should contribute a varying percentage of the year's estimated requirements, according to their reputed means, and no agreement could be reached upon the relative assessments, the plan had failed. I chanced to have with me a copy of the printed by-laws of the Yokohama Jewish Benevolent Society, upon the basis of which I drafted a constitution for a similar body in Singapore, but I did not remain long enough to see it ushered into existence. A similar neglect had also, I was told, characterized until recently the congregational cemetery, which had formerly served as pasturage for cattle; but now it was tended and visited regularly. There was no recognized undertaker yet, however, and every death meant a wrangle as to who should carry out the burial. A hearse was not used, the bier being always borne from the house to the grave, 
followed by mourners. The tombs of the Ashkenazim were separated from those of the Sephardim, and the tombs of the Cohenim from them both. Yea, in their death they are divided.

The only institution that represented a certain degree of united organization was the Myrtle Club, which, despite its non-Jewish name, was the social rendezvous of local Jewry. There the members foregathered daily, for tea and talk, cards and billiards, tennis and dancing, and there they read Jewish and other newspapers from various parts of the world. And there, too, as the only common ground of the entire community, I convened a special meeting to found a Zionist Society, so that the labours I had begun to secure the co-operation of the Jews of Singapore in the upbuilding of the Land of Israel might be regularly continued by them after I had left.

5

Thirty-six hours after leaving Singapore the s.s. Ekma, on which I was bound for Calcutta, dropped anchor some distance from the picturesque port of Penang. As soon as breakfast was over a young co-religionist came on board to greet me and take me on land. He was a son of Mr. Ezekiel Menasseh, the oldest Jewish resident in Penang. Thanks to a steam launch and a motor-car I was soon brought to the pleasant-looking house of Mr. Menasseh, a little grey-haired man, who gave me a friendly Shalom Aleichem. He took me up to a large sitting-room, whence we had a good view of the town in various directions, and using a Biblical phrase, he said that his house was 'al em ha-derech (on the cross-roads). On the wall was a framed oleograph, showing scenes in the Holy Land, with Hebrew inscriptions, and the eyes of the old man lit up with wonder when I told him that I had actually seen those venerated sites.

My host told me that, like most Jews in the Far East, 
208 THE JOURNAL OF A JEWISH TRAVELLER

he had come from Bagdad and had settled in Penang over thirty years ago. Until recently he had been the only Jew there, but the tribulations of war had brought a few other Jews from Bagdad, mostly poor pedlars, who consorted with Chinese and Malay women and lived debased lives. As for Mr. Menasseh, he had, despite his isolation, remained faithful to orthodox tradition. He rose every morning between four and five, when the sun was already up, and said his prayers in full. He kept a kosher house and had his own stock of poultry. He had been studying Malbim's ${ }^{1}$ Commentary on the Book of Daniel and showed me a passage in the last chapter which foretold that the restoration of Palestine would take place about the years I920 and I922.

"I showed this to Mr. Menasseh Meyer," he said, " and he thought it was most remarkable."

"And well he might," I added, as I read through the commentator's chronological calculation.

Young Mr. Menasseh then took me out for a drive to see something of the beautiful scenery in the neighbourhood. We traversed a fine straight road bordered by towering palms, with magnificent vistas on either side, and passed an interesting group of Malay huts, built some distance from the ground; and after reaching a famous waterfall, which broke the noonday stillness with its ceaseless plashing, and gazing out at the mirror-like sea, we speedily returned. But we had scarcely begun " tiffin" when the news came that the Ekma would be casting anchor very shortly; and so, abandoning the meal and taking a hurried farewell of the family, I was driven post-haste to the shore, where it was necessary to charter a special launch to reach the ship. Five minutes after I had stepped on board the vessel continued on her northward course. ${ }^{2}$

1 Famous Russian Rabbi and scholar (1809-1879).

2 I visited Penang after Java, but it seems more convenient to include this description of it in the chapter on the Straits Settlements. 


\section{CHAPTER XXVI}

JAVA

I

BATAVIA

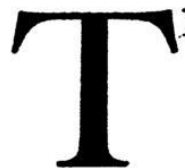

HE voyage from Singapore to Batavia was as smooth as a trip on a shallow lake, but the equatorial waters through which we sailed were much warmer than any inland sea that I had ever crossed. The Melchior Treub, a clean and spacious vessel, looked cool in its new coat of snow-white paint, but the enervating atmosphere left one little energy except to lie in a long deck-chair and lazily gaze across at the low coast-line of Sumatra. With closed eyes I could have imagined, from the hubbub of Dutch conversation around, that we were cruising in the Zuyder Zee, but the illusion was dispelled by the sight of my fellow-travellers in their white clothes and of the chocolate-coloured Malay stewards. These undersized natives flitted about with bare feet and with heads covered by curiously arranged kerchiefs, from which two knotted ends protruded like horns ; whilst, when not hurrying at somebody's call, they squatted on their haunches on the deck or in the passages below, preserving the silence of an undertaker's mute. Never shall I forget how I was momentarily startled when I first espied one of them, motionless as a gravestone, bunched up in a shadowy recess near my cabin door. Fortune and a friendly purser-or, perhaps, rather a slight addition to the purser's fortune-procured me a two-berth cabin entirely to myself, a very welcome boon in that sultry region. 
On the middle of my bed lay a narrow bolster some three feet long, which obviously had no place beneath my pillow, and upon inquiring its purpose I was told that it was to rest one's legs on-in the restlessness of a tropical night-and that it bore the strange name of " the silent wife." In every hotel in Java I afterwards found awaiting me in the bedroom such a " silent wife."

Thirty-six hours after leaving Singapore we glided very early in the morning into the harbour of Batavia. A deputation of four young Dutch Jews, headed by Dr. Lichtenstein, came on board to greet me, and then they conducted me in a motor-car to the residential suburb of Weltevreden, where the streets, as in Holland, were traversed by narrow canals, in which the natives could be seen at all times of the day washing their dusky bodies and still duskier clothing. The Nederlanden Hotel at which I put up was of curious design : it was fronted by a terrace covered with little tables and chairs, from which a corridor led to a spacious dining-room, whilst on either side of the terrace there was an open approach to a courtyard, which was surrounded on all sides by a two-storied block of bedrooms, in front of which-both on the lower and the upper floor-ran a loggia furnished with table and lounge-chair for every guest.

My companions lost little time in taking me round, for my stay in Java was to be limited to five days, in order that I might return by the same vessel : otherwise I should have had to extend my sojourn by a week before being able to sail by the next steamer. Among the few persons upon whom we called before noon was a rich Austrian Jew, who had been living in the country over twenty years. He received us in his cool sitting-room, which was furnished with bamboo chairs and table, in his pyjamas and sandals, and apologized for his attire on the ground of the temperature. He at once proclaimed himself a sceptic as to the advisability of bringing the Jews back again to Palestine, and made no secret of his . view that they should become absorbed among the 
nations. His mentality, I soon learned, was typical of the bulk of the Jews in Java, though he was sympathetic enough to ask us to come again.

At noon the heat became too oppressive to allow us to continue on our expedition, so after lunch I took a siesta for a couple of hours behind drawn blinds, and in the cool of the evening I was driven to the Theosophical Hall, a plain white building, to address a public meeting. I stood at a desk which was draped with the Zionist flag that I had brought, and spoke to about thirty people, of whom many were Christians, including the President of the local Theosophical Society, Dr. van Hinloopen Labberton. The latter, at the conclusion of my English speech, asked whether the Jewish restoration of Palestine had anything to do with the Second Advent. I replied that the Jewish people were trying to carry out their ideal solely on account of its own supreme virtue, and without regard to the meaning that might be attributed to it by the followers of another faith, and if there was no conflict between the two so much the better. When the meeting was over I caught sight in an adjoining room of a semicircular group of young Japanese men and women all kneeling and listening reverently to the discourse of a teacher who was also on his knees. It was but a fleeting vision, but the strangeness, the silence and the devoutness. of the scene moved me deeply.

My friends then took me to a club for dinner. As the night air was warm we sat on the terrace at a table illumined by a red-shaded light, and amid the quaint whirring of invisible insects overhead we spoke about the conditions of Jewish life in the colony. I learned that there were several hundred Jews-perhaps as many as 2000-scattered about from Batavia to Sourabaya, but as most of them concealed or denied their Jewish origin it was impossible to form an approximate estimate of their numbers. Dutch Jews had been living in the country for a very long period and had played an important part in its commercial development, and it was 
even supposed that its discoverer, Jan Petersen Coen, as his name seemed to indicate, was a Jew. There were many Jews occupying Government positions, the most notable being the Resident of Sourabaya, whose name was also Coen. But there was no Jewish life in the communal sense, mixed marriages were frequent, and the only form of association consisted of a few struggling Zionist societies. My companions were all ardent votaries of the Jewish national idea, and had bravely succeeded in maintaining their enthusiasm in this spiritually asphyxiating atmosphere. Three held posts in the Government service-one as lecturer on tropical diseases, another as naval surgeon, and the third as a postal official -but they were all intensely desirous of transferring their labours to Palestine. They told me that, owing to the indifference of the wealthy Jews, there was not a single synagogue throughout Java, though, on the High Festivals, religious worship was held in a private house or public hall in the three or four largest centres. But despite the apparently determined effort of the community to efface itself, one of the local papers, Nieures van den Dag, persisted in reminding its individual members of their racial affiliation by its periodical anti-Semitic pin-pricks.

Early next morning, accompanied by the naval surgeon, I called upon several Bagdadi Jews, who formed the most othodox element of the community, as did their brethren in the other communities of the colony. Indeed, in the office of one of them there hung on the wall, in a simple frame, a big Hebrew Cabbalistic inscription, adorned with an outstretched palm (whereof each finger bore the name of a guardian angel), which had been designed by a Bagdad youth who afterwards turned out a rogue. We also called again upon the wealthy exile from Vienna and engaged once more in a discussion about the potentialities of Palestine, but on this occasion we at least received some monetary compensation for our loss of time. 
BANDOENG

After travelling nearly six hours in a comfortable train $I$ arrived in the evening at Bandoeng, where $I$ intended staying overnight, with a view to continuing my journey early the following morning to Sourabaya. I had not been in the vestibule of the hotel more than a few moments when I noticed a young man of Jewish appearance, with whom I entered into conversation. He was a dealer in diamonds and had come from Antwerp, and he had a bag of gems in his hand, which he was waiting to get locked up in the hotel safe. As our conversation developed I learned that he was a relative of the diamond merchant who had tried to obstruct my mission in Singapore, but I prudently mentioned nothing about that annoying experience.

My friends in Batavia had given me the name of only one Jew in Bandoeng, a Sephardi, to whom I telephoned upon my arrival, and immediately after dinner I found him-an elderly man-waiting for me outside my room. His prompt response was due to his having mistaken me for another person of my name whom he was expecting, but upon my explaining the situation he readily agreed to give his mite for the rebuilding of Zion and invited me home. As we were leaving the hotel we met another Sephardi, a young man, to whom he introduced me. "Are you the gentleman who has been offering diamonds ?" asked the latter. "No," I replied, "I have something more valuable to offer."- "Indeed!" said he.- "Yes, I offer you the opportunity of participating in the realization of a glorious ideal." Explanations followed, and the young gentleman, who was anxious to join a couple of ladies who were waiting for him in a carriage, cheerfully gave his donation.

The elder Sephardi then drove me in a curious little cab, which was like a dog-cart protected with roof and side-curtains, to his house. His wife was glad to welcome 
one who had been in the Holy Land, and pointed with pride to a picture on the wall, which was an oleograph of historic sites in that country. They had both come many years ago from Bagdad, and they spoke with sadness of the many Dutch Jews in Bandoeng who concealed the faith of their fathers; and then they asked me about what was happening in Palestine and uttered the wish that they might be favoured to spend the evening of their days on its sacred soil.

As I returned to the hotel I passed many joyous groups of Chinese who were celebrating their New Yearon February 7 th. The Chinese quarter was brilliantly illuminated, bands of music were headed by torchlight bearers, a masked jester was amusing a crowd with funny stories, and the air was rent with the crackling of fireworks.

It was still dark when I rose the following morning to catch the quarter-to-six train to Sourabaya. There is no railway traffic in Java at night, so that, owing to the long distances that separate the principal towns from one another, journeys must often be begun before daybreak. But the discomfort of this excessively early rising was afterwards forgotten in the contemplation of the picturesque scenery. The route was an unending expanse of luscious vegetation, miles of coco-nut palms alternating with vast rice-fields and dense forests; and as we slowed down through the villages we caught a glimpse of brown-skinned men and women bathing in rivers and brooks, and of naked children romping along the dusty roads.

\section{3}

SOURABAYA

It was with a feeling of relief that I reached Sourabaya, even though the station roof re-echoed with a torrential downpour, as the ride of fourteen hours had left me tired and covered with the dust that flew into the carriage despite the closed windows. Some friends took me to an 
hotel, where I quickly washed and changed, and within half an hour I was at another hotel, where dinner was laid for twenty-four persons. The festive table arranged in my honour was also intended as a lure to lukewarm sympathizers who could not be relied upon to attend the public meeting to be held the following evening, and, indeed, the tardy arrival of some of the guests seemed to indicate that they were apprehensive of some ulterior. purpose. It was nine o'clock before we sat down, all of us in the conventional evening dress of Western climes. A former settler from the Palestinian colony of Zichron Jacob, transplanted hither by an inscrutable destiny, appropriately presided and delivered the first of a number of speeches of welcome, and it was eleven o'clock before I was able to rise and respond to the chorus of cordial greetings and launch my appeal. The result was a collection of $£$ IoO, which, I was assured, would at least be trebled before I left the city, despite the economic depression that prevailed in the land.

A young Russian Jew, whose father had already gone to Palestine, took me round in his motor-car the following day to some selected members of the community. One was a Roumanian Jew, the owner of a large store, who was married to a native of Maderoe, by whom he had children; but despite the ostracism which his marriage involved, he generously responded to my request. There were five or six other Jews in the city, I was told, who had native wives : they were all made to feel, in some degree, as social outcasts, as they could not appear in public with their wives nor take them on visits to friends. These mixed unions were one of the effects of the lack of an organized community, which reduced the opportunities of social intercourse, whilst another and more prevalent consequence was the undermining of the Jewish consciousness, which seemed to be leading to drift and apostasy.

One of the saddest experiences that I had was in conversation with a middle-aged merchant, who had formerly 
2I6 THE JOURNAL OF A JEWISH TRAVELLER

been the consular representative of a Central European country. He saw no possibility of a solution of the Jewish question by the establishment of a Jewish Commonwealth in Palestine : he thought that the hatred of the Jew was too deeply rooted, and as it was now more violent and widespread than it had ever been before the war he considered that the only solution lay in complete assimilation. " But," I said, " it is impossible for all the Jews in the world to be assimilated, even if they wished." To which he replied : "Each individual Jew can decide his own fate and become assimilated." Then, lowering his voice, he added: "I have taken the extreme step-I am no longer a Jew." A look of unutterable misery and humiliation spread over his face as he made this confession of apostasy.

For the moment I could not speak; then I said : "So you have abandoned your own people and joined the ranks of their persecutors?"

He was silent for a while, weighed down by a conflict of emotions. "It never appeared to me like that;" he said wearily. "Still, though I have no faith in Zionism as a solution of the Jewish problem, it has my earnest wishes for its success."

I left him bowed over his desk, and continued my round of visits. In the evening I addressed a small meeting in the Masonic Hall, and the following morning, rising again before the dawn, I caught the quarter-to-six train to Semarang.

\section{4}

\section{SEMARANG}

Seven hours later, after travelling through rich tropical landscape, I reached my destination and was welcomed by Mr. Sayers, a prosperous merchant of Bagdadi origin. He took me to the house of Dr. Leo Straus, a teacher at a higher-grade school, whose guest I was to be. Dr. Straus apologized for being in pyjamas, but the oppressive heat was a sufficient explanation. His wife, a well- 
educated Russian Jewess, with whom I conversed in German, complained of the dulness of life in Java, where the burning sun seemed to frizzle people's brains and leave them little energy for any intellectual interest.

Soon after lunch Dr. Straus drove me to Mr. Sayers, who had meanwhile prepared a portentous-looking list, headed Keren Hayesod (Palestine Foundation Fund) in bold Hebrew letters, and after he had put down his own donation as 500 gulden, we set out on our campaign, my host holding the list in a cardboard portfolio. We made good progress, for within an hour and a half we had nearly quadrupled the initial amount. At one office I met a German Jew who, on hearing my name, asked me whether I had been in Ruhleben, and on receiving my reply, said that he had read my book, The Ruhleben Prison Camp, while he was interned in the Ahmednaggar Camp in India. "I have lost all my capital and have to begin again," he said ruefully. "I managed to keep my capital throughout the war," I replied. "So ?" he asked curiously. "Yes, here it is," I rejoined, producing my fountain-pen.

We called upon the Jewish proprietress of a millinery shop, in which the floor was covered with serried ranks of stylish hats resting on equidistant stands. Dr. Straus made an eloquent little speech about self-taxation for Palestine, whereupon the lady, looking rather flurried, referred us to her husband, who, she said, was still at his office, not far off. So we went to see the gentleman, who, with an air of amusement, told us that he had just had a telephone message about us from his wife, who thought that we had come for the income-tax.

Early in the evening I was taken to the Masonic Hall to address a meeting that had been advertised in the local press. An elderly Russian Jew was already waiting, a member of a Russian operatic company that was playing at the local theatre. He was overjoyed when I spoke to him in Yiddish. Not knowing who I was, he said that he had heard that the Zionist Emissary was going to 


\section{I8 THE JOURNAL OF A JEWISH TRAVELLER}

speak that night, and he was anxious to get his help to go to Palestine. He told me that he had been a cantor at Kharkoff, but owing to the war troubles he had fled to Siberia-to Tobolsk and Irkutsk, where he had joined an operatic company, with which he had travelled to Tokyo and Shanghai, Manila and Singapore, Calcutta and Bombay. The company had wished to go farther to Palestine, but as they could not obtain the requisite permission they had returned to the Far East. They had already performed at Batavia and were appearing another few weeks at Semarang.

The meeting, over which Dr. Straus presided, was unusually small, but it was nevertheless instrumental in swelling the list of donations. The old actor, having now discovered my identity, approached me again. He told me that he had set his heart upon going to the Land of Israel, that he had saved about $£ 60$ for the purpose, and that he was sure his sons in Odessa would help him after he had reached Jerusalem. He begged me for a letter to facilitate his admission, adding, with a sob in his throat, that the Almighty would bless me if I gratified his wish.

After dinner my host and his wife took me to the Pavilion Hotel to see an exhibition of paintings by Leonid Gechtoff, a Russian Jew. As it was after ten we found the salon closed, so we drove to the theatre in quest of the artist. Our car was stopped by the police a few hundred yards before reaching the building, as, in consequence of the great number of open windows, traffic had to be kept at an adequate distance so as not to disturb the performance. Mr. Gechtoff readily left the theatre and took us back to the hotel to give us a private view of his productions. He was fair, fat and forty ; he had studied art at Moscow and had left Russia in consequence of the war. He had been living in Java for the last three years, and had apparently few, if any, rivals there in his profession. His paintings all represented Java landscapes, displaying a fine sense of colour, 
and giving a vivid rendering of the beautiful scenery. They ranged in price from 800 to 4000 gulden, and some were already sold. Our visit concluded with the addition of the artist's autograph to our subscription list.

We then returned to the theatre, where the opera Thais was being performed in Russian. In the foyer I met the manager, a burly Russian Jew, with black moustache and rotund paunch, who was greatly interested in Palestine. He introduced me to his wife, who was born in Odessa and boasted of her acquaintance with Abraham Goldfaden, the "Father" of the Jewish stage. In the course of our conversation about the Holy Land she asked: "And are they building already?"

" Building what ?" I asked.

"The Beth Hamikdash (Temple)," she replied with emphasis.

"Not yet," I said. " There are some other things that have to be built more urgently, and the money available is not too plentiful."

The manager told me that both he and his wife were eager to go to Palestine. He asked whether there would be an opening there for their operatic company, and assured me that he had the costumes and stage properties for a varied operatic repertoire. I replied that it would be necessary to have the texts translated into Hebrew, whereupon he said that he would think the matter over. He added his contribution to the list and then invited me to witness the remainder of the performance. The parts of the monk and his beloved were feelingly rendered : both artistes had strong, melodious, well-trained voices, which held the entire house in thrall.

When the opera was over the manager brought me a handsome young fellow, a member of the choir, who said that he also wished to contribute.

"You know what it is for ?" I asked.

" For the Land of Israel," he said, with a joyous gleam in his eyes. 
5

Early the following morning I took farewell of Dr. Straus, who had to begin his duties at school at halfpast seven, and a couple of hours later I boarded the launch that took me back to the Melchior Treub. After an uneventful day I reached Batavia again, and as the ship was to remain in port until late in the afternoon I took advantage of the interval by making an excursion in a motor-car to the picturesque town of Buitenzorg, famous for its gardens. The journey was along a fine smooth road, bordered by palms and bamboo trees, on which we passed clusters of Malay huts built a few feet above the ground, herds of buffaloes driven by little boys, and groups of squatting women with uncovered bosoms. Unfortunately the gardens were closed that day, so I had but an unsatisfying glimpse through the huge gates of the splendid vistas beyond.

On returning to the ship I found my Batavia friends awaiting me and anxious to learn how I had fared since I had left them. They were more than surprised when they heard that the fruits of my brief campaign amounted to nearly $f 900$. Nor was the list concluded, for there were several Jews on board, some- of whom were now also caught within the net. Indeed, I had more Jewish fellow-travellers on that trip back to Singapore than on any other of my numerous voyages. There were two Bagdadi Jews, a trio of diamond merchants from Holland, a Danish tenor and a Russian violinist, besides two or three persons who were apparently Jewish but studiously held aloof. The Dutch steward put me at the same table with the diamond dealers, one of whom, I learned, was a nephew of the Chief Rabbi of Holland. They seemed to have all done well by selling gems to Chinese merchants, and they required little persuasion to help the cause of Zion.

One of the Bagdadis not only gave himself but undertook to collect contributions from other Jews whom, 

$\cdot$ 


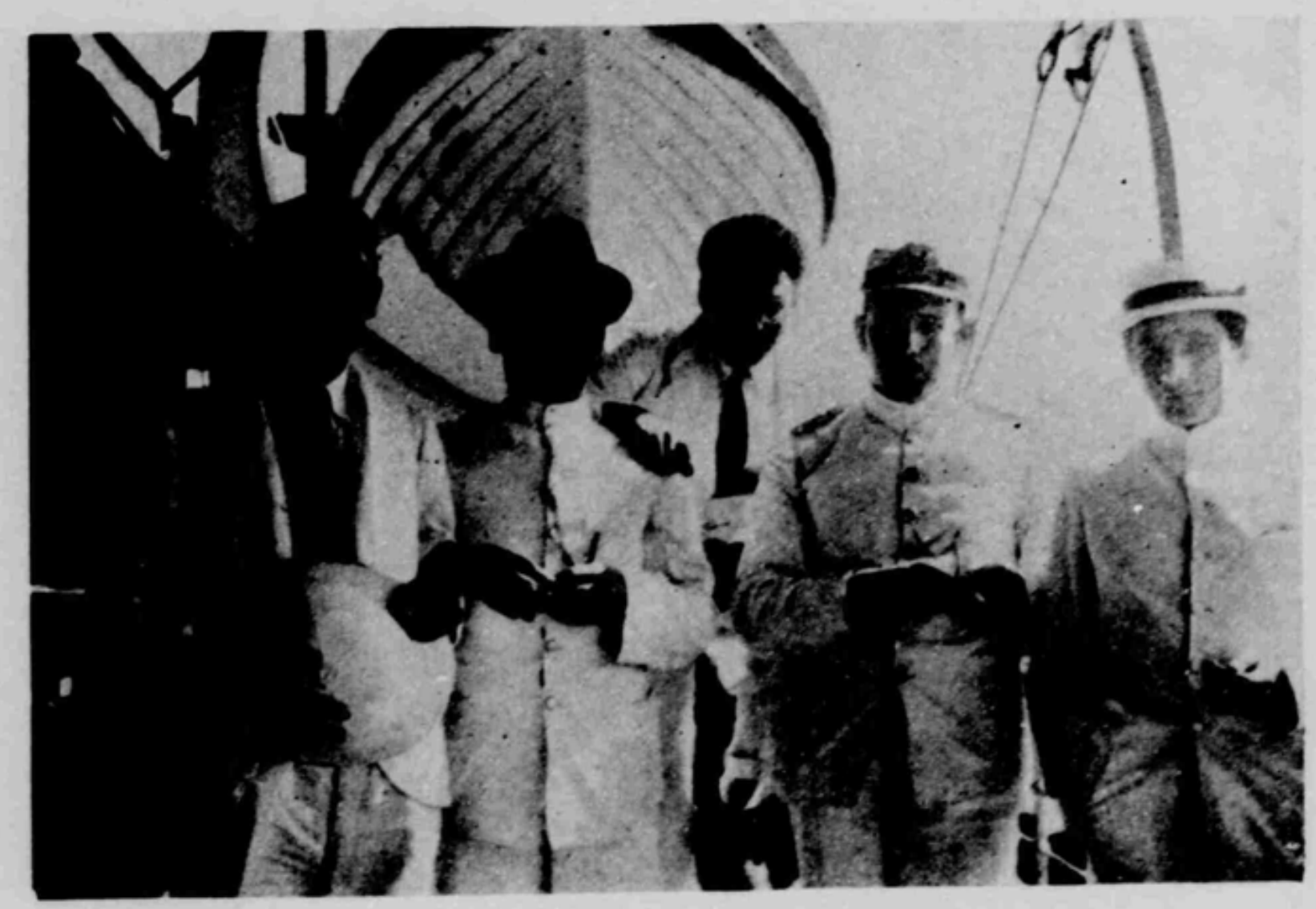

ZIONISTS AT BATAVIA

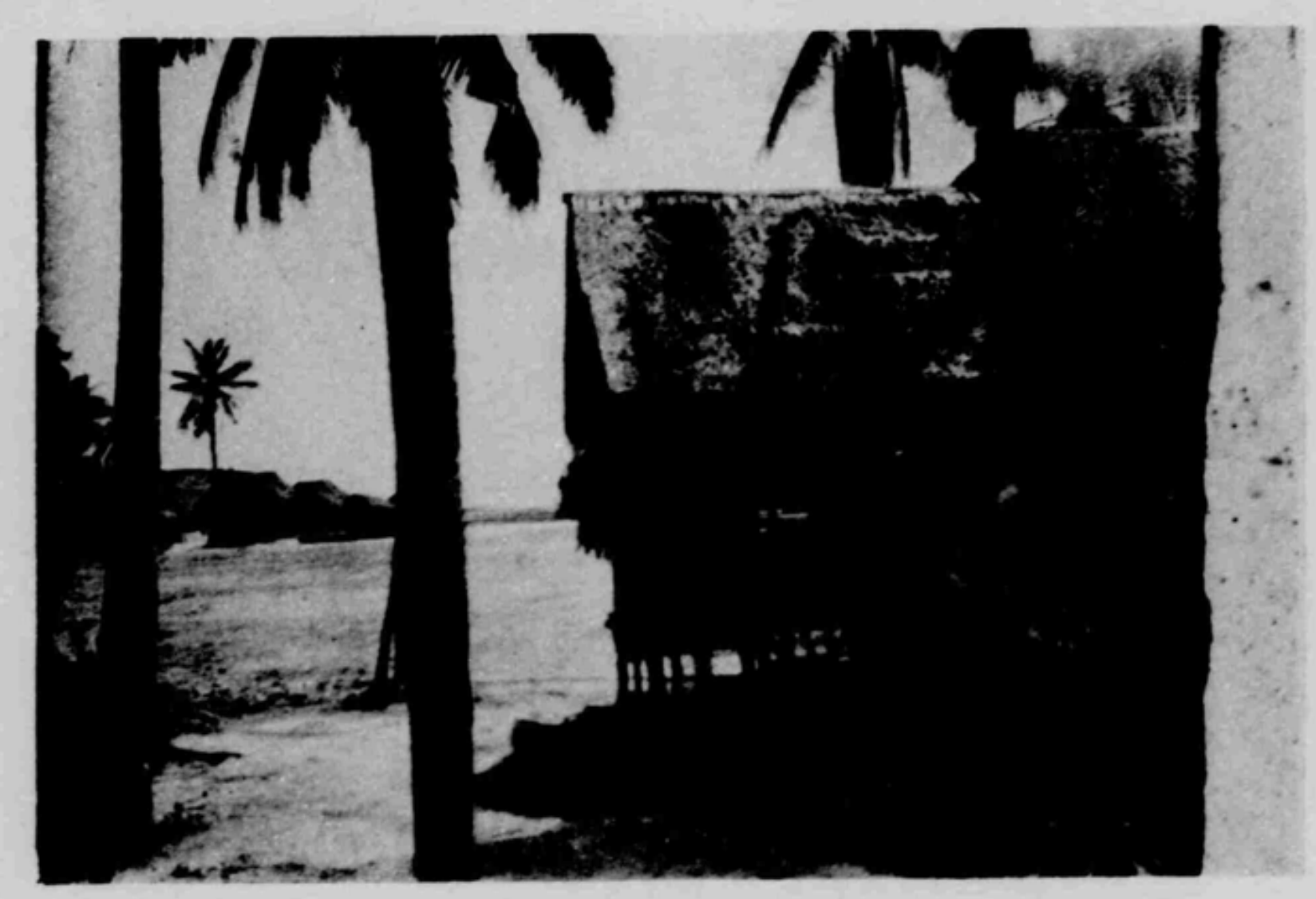

MALAY HUTS AT PENANG 
he said, he met in the course of his travels through Sumatra, Celebes and the other Dutch Indies. He told a doleful tale of Jewish life in Java, which he described as "Jewish death," but even a Jewish death had not always been followed by a Jewish burial, as it was due to his instrumentality that a cemetery had been secured for the Jews of Sourabaya. The Government had been willing to grant a plot for this purpose for nothing, but as Jewish law (based on the procedure in connection with the Cave of Machpelah, which Abraham would not accept gratuitously) required that payment should be made, the plot was obtained for quite a nominal sum. From this fellow-traveller, as we lay on our deck-chairs watching the golden rays of the sun dapple the rippling waves, I heard some curious anecdotes about the Jews in Java, one of which seemed reminiscent of patriarchal days. A wealthy Bagdadi, who had an only grown-up daughter, had a passionate longing for a son, and, as his wife had been unable to gratify his desire, he decided, with her consent, to take into his house a non-Jewish concubine. To the reproaches and remonstrances of his friends he replied that he was acting in accordance with Biblical precedents. In due course the concubine conceived and bore him-a daughter; so he gave her 5000 gulden and she departed. Shortly afterwards his wife, after an interval of nearly twenty years, was delivered of a son.

I had no lack of entertaining company on that brief trip. The burly Danish tenor, who had a Spanish Jewess as grandmother and who sported an Italian name for professional purposes, turned out to be a relative of a Manchester Rabbi. He had sung in nearly every hall throughout the Far East and seemed an embodiment of the Wandering Jew, but without his sorrows. His companion, the sprightly violinist, had first become a musician in the Russian Army in the days before the war, but as he had not been permitted to stay in Moscow on account of being a Jew, he had shaken off the dust 
222 THE JOURNAL OF A JEWISH TRAVELLER

of his fatherland from his feet and begun to roam through all the lands of the earth. He had played in England and America, in South Africa and New Zealand; he had appeared before Maharajahs in India and before the art-loving King of Siam. One evening, in his cabin, he took out his violin and played an old Jewish folk-melody, a wistful plaintive air from the Polish Ghetto, now sad and sombre, recalling the moans of generations of suffering, the sobs of countless victims of persecution, livening up anon to a spirited and jubilant measure, and then re-echoing with the tramp of the brave hosts marching to the dawn of a brighter day..... And as he put down his bow he said pensively, "I should like to play that in Jerusalem." 


\section{CHAPTER XXVII}

\section{RANGOON}

7 HE Ekma, on which I had sailed from Singapore, reached Rangoon at dawn on the third day after leaving Penang. It was a smooth, uneventful voyage, on which I made the acquaintance at table of a Captain Browne, an airman, who had flown in General Denikin's army in the South of Russia, and whose observer had been shot down behind him on a perilous flight. The ship was to remain in port three days before continuing her trip to Calcutta, thus affording me ample time to invoke the generosity of the local Jewish community and to see the sights of the city.

I was greeted on board by the president, Mr. A. J. Cohen, and Mr. Meyer Meyer, who drove me to the house of the latter, where I was to stay during my visit. The house was a palatial residence in the suburbs, surrounded by extensive gardens, and comprising a small farmyard with cows and poultry for the household's consumption. There were thirty-six Burmese servants to look after the establishment, but their vigilance was of dubious value, as some of the denizens of the farmyard regularly strayed to other domains and were never recovered.

Immediately after breakfast I was driven back to town, to the large grocery store of Mr. Meyer in Dalhousie Street, in and around which thoroughfare are situated most of the shops and offices of the Jewish inhabitants. There are about 500 Jews altogether in Rangoon, most of whom have originated from Bagdad, and consequently they are trilingual, speaking Arabic among themselves, 
Burmese with the natives, and English with Europeans. They have the unique distinction of possessing an endowed synagogue, which was built about 1880 by the late Mr. B. Meyer, and which is maintained out of the rents derived from the adjacent shops, so that public worship is gratuitous, though hardly more popular on that account. Indeed, there is a disadvantage in this arrangement, as the community has only a Hazan to conduct its prayers and no Haham to expound their meaning-a deficiency that is bound to affect its spiritual welfare. It also has a day school, built about I9I0, and attended by I40 children, which receives a Government subvention even larger than the amount contributed by the community.

I spent the earlier part of the day in calling at the various English newspaper offices and explaining the object of my mission, and then took a gharry to the famous Schwedagon Pagoda. On reaching the outskirts of the famous shrine I was requested by an attendant to take off my shoes, so as not to profane the hallowed ground. This practice of requiring Western people to conform to the native custom was, I was told, introduced after a visit by Colonel J. C. Wedgwood, M.P., who was reported to have said that there was no justification for Europeans-or even Americans - to walk roughshod over the religious susceptibilities of the Hindu. After removing my footgear I had to walk in my socks up several hundred steps, which were fortunately arranged in several series and in an easy gradient, and which were covered all the way with coco-nut matting. The stairs were flanked on either side with little stalls and shops, at which were sold flowers and fruit, cigars and chocolates, picturepostcards, pictures of Buddha and sacrificial tapers, whilst I was jostled at every step by crowds of children, beggars and dogs. The Pagoda itself is a very large and lofty bell-shaped structure, thickly overlaid with gilt, which shone resplendent in the sun. Around it ran a wide circular promenade, which was bordered on both sides by all kinds of smaller picturesque shrines, some of 
carved wood, others containing white-painted Buddhas, and some a Buddha twenty-five feet high, whilst within them were many worshippers, especially women, either kneeling or prostrate, with flowers and lighted tapers in their hands. The place was infested with beggars, both able-bodied and crippled, the most remarkable of whom was a little brown deformed dwarf, who looked like some evil imp, holding up a little shrivelled bare leg and putting it down again, whilst calling repeatedly and incessantly in a rasping voice: " $P a-i-y a, p a-i-y a$, $p a-i-y a, S a h^{\prime} b-p a-i-y a, p a-i-y a, p a-i-y a, S a h^{\prime} b ! "$ It was a disgusting spectacle, from which I hurried away, though the raucous cry long re-echoed in my ears.

After tea I was taken to the synagogue, before which and within which was assembled an eager throng, who gazed at me with open-eyed curiosity. It was composed entirely of men and boys, many of them wearing white baggy trousers and embroidered round caps, and one or two the flowing white garb and scarlet waist-band of Bagdad. The synagogue was a large and substantially built edifice, wherein a few memorial lamps, suspended in mid-air, diffused their pale beams over the unwonted scene. I spoke from the little platform before the Ark and was listened to with close attention, but in the middle of my address one of the wealthiest members of the congregation went out to keep an appointment and was followed soon afterwards by another rich member, so that my hopes of a golden harvest began to dwindle. By the time I had finished it was getting dark, whereupon it was decided to offer up prayers immediately, and as, upon their conclusion, the congregation began to dribble out, the collection had perforce to be postponed.

But early the next morning I began to reap what I had sown. Accompanied by the president, I first called upon Mr. Sassoon E. Solomon, a spruce, alert merchant of a Western type, who headed the list with 3000 rupees, and then I was conducted to other leading Jews in the 


\section{THE JOURNAL OF A JEWISH TRAVELLER}

order of their reputed wealth-a hierarchy that is both known and punctiliously respected in every community of Eastern Jewry. My guide and counsellor during part of this tour was a Mr. Menasseh, a genial old man, who, when a sympathizer wrote down on the list "I00," immediately prompted him : "Make it ror-Mi-chael-for luck! "-a suggestion that was readily complied with : for the numerical values of that Hebrew phrase, "Who is like unto the Lord ?" amount to Ior, and the giver of this sum believes that, like the quality of mercy, it blesseth him that gives and him that receives.

There were some who contributed who had not even been present the previous day at the synagogue, and who, indeed, never entered it except under the potent spell of the Day of Atonement. One was a merchant born in London, who was married to a Burmese lady, and the other was also a merchant born in London, but married to a Japanese lady. The latter, an elderly gentleman with a merry twinkle in his eyes, had been living in the East for the last fifty years, dividing his time between Japan and India. He told me that he would not go to Palestine unless I could promise him a regular supply there of Dutch herrings and píckled. cucumbers, although he could always be sure of an abundance of olives. After reading through the message from Sir Herbert Samuel which I showed him, he remarked that the latter's brother had been his guest many years ago in Japan, meaning Sir Marcus Samuel (now Lord Bearsted), who belongs to quite another family. He also boasted of having played poker in the distant past with Lord Reading, whose arrival as Viceroy was then expected in a few weeks' time. But what impressed me most of all was a quaint AngloHebrew limerick, which he recited with gusto :

"There once was a man Reb Ephraiyim

Who fell into the mayim (water),

So they fished him out,

As dead as a trout,

And took him to the Belh Hayim (cemetery)." 
I discovered that there was a little coterie of AngloJewish bookmakers in the city, who travelled regularly between London and Rangoon. Accompanied by the president of the community I called upon one of them at his flat, on the entrance-door of which there was affixed a card announcing the hours at which he was at home. He received us in a gaudily coloured skirt, which he wore, like the natives, in place of pyjamas, and he gave us not only a friendly welcome but also a cheque. He rather astonished us by remarking that he belonged to an orthodox family in England and that his brother was the president of an important provincial synagogue, and then, in a penitent key, he mentioned that it was some years since he had been inside the local synagogue and he would like to become a member. The sentimental "bookie" was particularly anxious about what might happen to him in case he should die, although he was still under fifty and appeared quite robust.

"You must let us know in time," said the president warningly.

"Well, I can't say for the present," responded the bookmaker, " and I feel fit enough to last another twenty years. But you never can tell:"

Another interesting person whom I met was a Pittsburg Jew, who owned a sugar plantation in the Solomon Islands. He treated me to lunch, but sought exemption from contributing to the fund on the ground that he was a regular subscriber to the Zionist Organization of America. Perhaps the most interesting character of all was a fat, loquacious gentleman, whose acquaintance I made in the motor-car in which I was driven by one of the president's sons back to the wharf. He was a Mr. Fleishman, born in Sweden and resident in Alexandria, who was now travelling to Singapore and Sumatra. He told me that he had been a captain in the International Forces that had landed some eighteen years before in Crete, and related an illuminating incident in connection with that stirring event. Fearing that there would be 


\section{THE JOURNAL OF A JEWISH TRAVELLER}

an attack upon the Jewish quarter at Canea, he asked his superior, Colonel Spitzer, if he could have a battalion to protect the district. "Prenez deux bataillons!" replied the Colonel. After order and security had been established and Captain Fleishman returned, his Colonel said to him quietly: "Tell me, Fleishman, are you a Jew?"

"Yes," was the reply.

"Bon," responded the Colonel, " nous sommes frères."

That Colonel was now General Spitzer, the brave owner of twenty-four decorations. The Admiral in charge of the blockading fleet on that occasion was an Italian Jew, and the chief intelligence officer was the son of the Rabbi of Lyons.

Another episode that Mr. Fleishman related as the car raced along the dusty road beneath the setting sun was less of historic than of humorous interest. Once; when travelling at night in Italy, he found himself alone in a compartment with another man whom he regarded suspiciously, as the latter stared at him shiftily through half-open eyes. They both spent a sleepless night, uneasy about one another. The following morning Fleishman asked his fellow-traveller what town he came from, and upon receiving his reply, inquired: "Do you know there a Mr. Rosh Hashana ?1 He is a near neighbour of Mr. Yom Kippur."2

"Oh, you are also a Jew," said the suspected stranger; "and I was afraid of you all the night!"

At the wharfside I took leave of my companions and stepped into a sampan, an elongated narrow boat curled up at the stern, in order to be rowed back to the Ekma, which was anchored half a mile away. The native boatman stood behind me plying his single oar, and, after following close in the wake of some tugs for a little time, was forced to steer into the open stream. The tide advancing in full strength, our boat was lightly lifted up by the waves as though it were a mere cockle-shell, and it seemed that at
1 New Year.
2 Day of Atonement. 
any moment it might turn turtle. The sun had set suddenly, and all around me the black waters rushed along with irresistible force, swollen with menace and fury, whilst the gloomy forms of the river-craft, with their phantom lights, flitted past. Nervously I clutched hold of both sides of the boat, as though to steady it whilst it skimmed over one crest after another, and peered intently and anxiously ahead to catch sight of the ship. But though the boatman pulled with vigour it took an eternity before we made any visible progress, and the lights of the Ekma seemed still to be miles away. Suddenly a wave came bounding over the side, the sampan lurched, and the fear of a disaster brought beads of sweat to my brow. The mere tilt by another inch would have overturned the frail craft and flung me at the mercy of the onrushing stream, for even a practised swimmer would have been powerless against those turbulent waves. A feeling of alarm crept over me, a medley of emotions played havoc with my brain, whilst above all the thoughts and memories that jostled one another in those moments of tense anguish shone the happy vision of home and its dear ones. . . . Not a word could I say to the boatman, as he knew no English, and though I tried to snatch a little comfort from the reflection that he had often rowed his boat on similar tides, I could not help fearing that the swirl that night might prove too strong for him, that his nerve and cunning might fail him. Only once beforeon that reckless ride through the Rimutaka Gorge in New Zealand-had I been brought so close to the grip of death and made to realize all the grisly horror of its diabolical embrace. The words of the Psalmist rang through my brain:

"The cords of death had encompassed me, And the straits of the grave had come upon me :

I found trouble and sorrow. ...."

At last we got beyond the violent current into smoother waters, and the silent boatman, ever standing, with a 
230 THE JOURNAL OF A JEWISH TRAVELLER

few deft strokes, swung his craft along the sheltering side of the ship. There was no more grateful mortal throughout the world as I clambered up the ladder to the deck.

A couple of hours later, as I leaned over the side of the vessel and gazed at the illuminated pagodas which filled the sky with a blaze of glory, I told the chief officer of the experience that I had gone through.

"You are lucky to have got back at all," he said. "The tide is very treacherous here, and many a sampan with the people in it has gone under. Next time, mind you use the launch." 


\section{CHAPTER XXVIII}

\section{CALCUTTA}

I

$\mathrm{N}$ the second night after leaving Rangoon I stayed up to see the pilot come on board. Very few people had remained on deck, as it was close upon midnight before he was sighted and the sea was extremely rough. In the distance I perceived a small light moving over the face of the waters, which shone with dazzling brightness beneath the pitch-black clouds : slowly it glided forward, gradually growing bigger, until it revealed a boat with twenty-four native oarsmen, whose vigorous, rhythmic rowing presented an arresting picture. The boat advanced with increasing momentum, and as soon as it came alongside there quickly emerged a burly figure, clad all in white, who clambered up the rope-ladder, stepped on to the deck, and disappeared into the helmsman's cabin above. It was the pilot, whose advent signified that we were not far from Calcutta. But it was another eighteen hours before we reached the harbour, as progress in the Hoogli was slow and laborious owing to the frequent shallows.

The scenery was flat and uninspiring, the banks of the river being unrelieved by anything but drab jute mills. The Ekma had been directed to the wrong wharf by some official, and it took an hour before the error was righted and we were able to land. At the foot of the gangway I was welcomed by a portly, distinguished figure, with venerable white beard, wearing a suit of tussore silk and huge sun-helmet-the Rev. E. M. D. Cohen, Senior Minister of the Magen David Synagogue. We were soon speeding in a motor-car to the flat of 


\section{THE JOURNAL OF A JEWISH TRAVELLER}

Mr. Ezekiel A. Gubbay, a wealthy and generous bachelor, who was to be my host, and in whose quarters I was made as comfortable as in a West End mansion. From my lofty window I had a glorous view of the city, including the vast green expanse of the Maidan and the beautiful gardens of the Governor's residence.

The history of the Jewish community goes back to the end of the eighteenth century, its most prominent figure at that time having been a trader named Shalom David Cohen, who was such a favourite of the Rajah of Lucknow that he had the honour of riding with him on his elephant. The community, which numbers some 2000 souls, consists, like most of the other Jewries in the Middle and Far East, of settlers from Mesopotamia and Southern Arabia and their descendants, those from Europe numbering hardly more than a hundred. Like their brethren in Rangoon, the Jews in Calcutta are also trilingual, speaking the Arabic of their fathers with one another, Hindustani with the natives, and English with Europeans. They are mostly engaged in various branches of commerce, especially as shippers and brokers, and carry on trade with Europe and all parts of the East. The Sassoons are represented here by branches of the fraternal firms of David Sassoon and Co. and E. D. Sassoon and Co., but no member of that famous house lives in Calcutta, and the managers of both branches are non-Jews. For the most part fortune has smiled upon the community, but it also has its poor-pedlars, petty shopkeepers and miscellaneous workmen.

There are three synagogues in the city, and as each congregation is endowed with an equal sense of independence, and there are still memories of an old feud between two of them, they seldom combine for a common cause, to the detriment of communal development. The first place of worship was built by the pioneer, Shalom David Cohen, but it has long passed out of use. The oldest of the existing synagogues, styled "Neveh Shalom," was erected in Canning Street over a century ago by 
another pioneer, Ezekiel Judah Jacob. It used to derive a monthly income of 229 rupees from a neighbouring compound belonging to it, which was distributed among the poor; but the compound was acquired by Elias David Joseph Ezra, who built upon it a more imposing shrine, called the "Magen David," and compensated the "Neveh Shalom" by a permanent income from a trust fund. Why it was found necessary to have two large synagogues cheek by jowl is a question into whose merits I did not inquire too closely, as I gathered that I should be trespassing upon delicate matters of family pride and communal rivalry. The third place of worship is the Beth-El, in Pollock Street, which was first built in 1855. by Joseph Ezra and Ezekiel Judah, and rebuilt and enlarged thirty years later by Elias Shalom Gubbay.

The largest and finest of the three synagogues is the " Magen David," at which it was arranged that I should speak, and it was therefore thought prudent that I should previously call upon some of the leading members of the other congregations in order to invite their attendance. One gentleman agreed to be present only upon condition that my address was not followed by the establishment of a Zionist Society. "We don't want to be under foreign subjection," was his emphatic declaration; "what right have people in London to dictate to us ?" In vain did I point out to him that there would be no dictation, but autonomy, and that the Society would benefit the community spiritually by linking it up with the concerted efforts of the Jews in all other parts of the world for the upbuilding of the Land of Israel. Another gentleman, far more sympathetic and intelligent, observed that what Palestine needed to make it the home of a Jewish majority was an immigration of the very same number that was liberated by Moses from Egypt, namely, 600,000 .

The attendance at my address, on the evening after my arrival, betokened no small interest, but although 


\section{THE JOURNAL OF A JEWISH TRAVELLER}

I emphasized that this was the first appeal that was made to the Jews of India to participate in the fulfilment of an ancient national ideal, the response, on the whole, fell short of my expectations. There were, indeed, two donations of 5000 rupees each, but all the other sums were much smaller. Several of the offerings were ror rupees, and in one or two cases $£$ Ior, the final digit representing-for luck-the Unity of the Godhead. The Rev. Mr. Cohen himself, who presided over the gathering, gave 1352 rupees, an amount produced by the multiplication of the numerical value of the Tetragrammaton, 26, by the number of weeks in the year. The inadequate result necessitated a round of personal calls, on which I was accompanied either by Mr. Cohen or by my host, Mr. Gubbay, and which yielded a fair reward. On these excursions we would often pass the sacred cow ambling leisurely along the pavement and helping itself to vegetables or other foodstuffs from an exposed store, and meet many a devout native returning with a little brass bowl in his hand from his religious ablutions, his forehead painted with ritual marks suggestive of the underlying purpose of the phylactery.

The following afternoon I paid a visit to the house of Mr. David Ezra, the president of the "Magen David" Synagogue and the son of its founder, to whom I had previously paid my respects at his office in Ezra Street. He had unfortunately been unable to attend the meeting owing to being in mourning for his mother. I was ushered up the stairs of a sumptuous mansion to a large room on the first floor, in which the Mincha prayer was being offered up by a number of men, some in Bagdadi costume, whilst through the open doorway of an adjoining apartment came a cacophonous chorus from an animated aviary-a score of parrots, parrakeets and other birds doing their best to drown the Hebrew supplications. After the conclusion of the service a flask of rose-water was passed round, and as each person shook it he uttered aloud the benediction unto the Almighty "Who createth 
all kinds of spices." Small cups of black coffee were then served, and the ceremonial was over. In the large garden at the back of the house I was awaited by Mrs. Ezra, who invited me to stay there for tea. There were some strange pets disporting themselves there-some monkeys chained to the ground and trying to get away, storks and peacocks strutting about, whilst a staff of barefooted native servants were looking after them. And in the midst of this unwonted distraction I related to my hosts some incidents of the sufferings of the Jews in Eastern Europe and invoked their aid in the establishment of the Jewish National Home.

I had written out a report of the synagogue meeting, and took it myself to the offices of The Statesman and The Englishman in order to ensure its publication. At the office of the former paper I was directed to the assistant-editor, who was bent over his desk with his shirt-sleeves rolled up, and upon his lifting up his face I was surprised to find that it was an old acquaintanceMr. George Pilcher, whom I had known ten years before as the foreign editor of the Morning Post. An exchange of views upon the events of the last decade inevitably followed, and Mr. Pilcher invited me to have tiffin with him the next day.

2

Shortly after my arrival in Calcutta I received the following strange letter, at the head of which were printed the name "Malkicedec Bonami" and the design of a curious circular lock.

“ Hon. SiR,

I am the Man and I am come! The Greatest Treasure of the World is my life, and God is keeping me as a stowaway in Calcutta. Apart of anagrammatical references to my identity the Bible is written so that every word there is Mathematically referred to my name and whereabouts. I took up the exposition of it. I 
mastered the Heaven so that no Man on Earth ever attained $\mathrm{I} \% \mathrm{a} / \mathrm{c}$ mine. There is also the mathematical reading of the Bible for Mysticism, for which I am the first to master it. I mastered also all Sciences. My biography in short is so : I am the only son of the Rabbi of Gordon in Bialystok, Lithau, born in Wolkowysk, and married to the daughter of Rabbi Israel David Miller of Grodno. I was formerly a bookkeeper in Warsaw ; then I opened a bookshop in Wolkowysk and was agent and correspondent in the Hebrew papers. In I905 I took two of my sons with me and left Russia to see my parents in Jaffa. The Revolution broke out then, and, therefore, instead of returning home I was advised to go anywhere with them. God caught me and brought me to India on the 7th Nov., I905. . . . I was in Bombay I2 years a teacher to the big and also a schoolmaster, then German English translator to a professor of the University, and etc. and etc. I took to inventions, my first recorded in Indian Patent Office No. II//I907. Last month I registered 6 inventions.

\section{Resp. Malkicedec Bonami.}

P.S.-The Godly Plan to set up Supermen (4 Races) is with me. God shall fight the world. India shall go."

"Malkicedec Bonami," I was told, was the HebrewFrench pseudonym of a gentleman with Messianic pretensions and erratic mentality. He called once or twice to see me, but unfortunately I was out, and he therefore sent me another epistle, in which he wrote :

"I am going to make a gift to the National Funda thing in which I am, at present, rich therein : wisedom. I am the Man, I am come. Last month I registered 6 new inventions and designs in the Indian Patent Office. One of them is No. 6657 which is the discovery of a New Principle in Optics based on the transparency of the Atmosphere which is showing the Sun (the Moon) when on the Horizon much larger and less bright than when 
seen on the Zenith. You shall be able to patent it also in English Patent Office and for all the World. It is a very important discovery in Glass-Manufacture.

You shall have to pay in the Indian Patent Office (if for a term of 14 years) the Privilege Rs.Ioo in less than 3 months, else you may forfeit all.

I brought with me my Bible Book with my Mathematical Exposition, which no man on Earth could find his way therein before the time has come. I have a long tale to tell-but God shall speak for me. I am the Man. Nothing could be done before my coming to the World."

I did not accept the offer of the optical invention, as I was somewhat afraid that it might prove a liability rather than an asset, even though it came from one who emphatically declared that he was " the Man." Another proposal was brought to me by a less eccentric wellwisher of Palestine : he was the owner of a house which he wished to raffle, and promised Io per cent of the proceeds to the Palestine Restoration Fund if I would co-operate in the sale of the tickets; but as he wanted to sell tickets of a much greater aggregate value than that of the house, the idea was unacceptable.

\section{3}

Early on the Sabbath morning I went with Mr. Ezekiel Gubbay to the "Magen David" Synagogue, which we reached at half-past seven. The attendance was rather sparse, and as the Rev. Mr. Cohen, wearing a big grey tophat, carried the scroll of the Law from the Ark to the Almemar, all the worshippers rushed forward to kiss it. Nobody stood as Segan at the reading of the Law, to which I was called up as Cohen and asked to schnoder. ${ }^{1}$ Through the open windows we could see the neighbouring synagogue, the "Neveh Shalom," which was on a somewhat higher elevation, and whose congregation literally

1 To make an offering. 
238 THE JOURNAL OF A JEWISH TRAVELLER

looked down upon us. In the middle of the service a flask of rose-water was handed round : it was shaken vigorously by each worshipper, who jerked out some spray and offered up the benediction to Him "Who createth all manner of spices." I could understand the purpose of this rite in this tropical country, a purpose that was reinforced by the large electric fans overhead, which whirred away in full vigour all the time. At the conclusion of the service a poor man approached Mr. Gubbay, flung himself on the ground before him, and was about to kiss his boots as a preliminary to asking for alms, when Mr. Gubbay indignantly turned aside and compelled the man to get up: It was a sudden scene of Oriental obeisance and begging that I shall never forget.

The venerable minister then took me to the Holy Ark to show me the scrolls of the Law. The structure was different from that of all other Arks that I had seen, as when the curtain was withdrawn and the door was opened one passed into a capacious chamber with a semicircular wall, along which was built the cabinet containing the scrolls. There were over a hundred scrolls altogether (some consisting only of the Haftaroth), ${ }^{1}$ all contained in silver cases with finely wrought designs, to preserve the parchment from becoming mouldy. Both scrolls and cases had come from Bagdad and had been presented in memory of various departed members of the community. As Mr. Cohen was explaining these things to me I noticed a pious old woman, who went slowly from one scroll to the other, touching each in turn with her fingers, which she reverently brought to her lips. It was the most touching scene of religious devotion that I saw throughout Far Eastern Jewry.

On leaving the house of prayer I found that there were 2 number of motor-cars in the adjoining street, waiting to take their owners home. The Rev. Mr. Cohen had a big rickshaw. He objected to the use of a motor-car on

1 Readings from the Prophiets. 
the Sabbath on the ground that its mechanism involved the kindling of fire; but its defenders claimed that his rickshaw coolie had to work very much harder than any chauffeur.

The following morning I came to the synagogue once again, as I had convened a meeting there for the purpose of founding a Zionist Society and making a fresh appeal. At the entrance to the shrine I was struck by two large memorial tablets, one in Hebrew and the other in English, erected in honour of the founder. The Hebrew inscription was a scholarly composition, beginning with an acrostic on the name Elijah and interspersed with Biblical phrases, which recounted in grandiloquent terms his benevolence and thoughtfulness. The companion tablet in English, which was not a translation, was sufficiently quaint and characteristic to deserve reproduction:

In grateful remembrance of

\section{ELIAS DAVID JOSEPH EZRA ESQUIRE of Calcutta,}

President, rather the father of the Jewish Community, who; to orthodox principles united

a heart susceptible of all that is good.

Charitable, benevolent, humble, and indulgent,

He sympathised in the sorrows and sufferings of his fellow-creatures.

With his commanding Authoritative

Yet affable words

He restored peace in many a household. With his vast means he provided for the poor.

He lived in the estimation

and affection of Coreligionists, Who rightly appreciating his great worth, erect this Tablet

to record to posterity their gratitude

for his innumerable kind acts

in the cause of humanity. 
240 THE JOURNAL OF. A JEWISH TRAVELLER

This Magnificent Synagogue

"MAGEN DAVID"

was built at his sole expense

on a site belonging to the old synagogue

" NEVEH SHALOME"

yielding monthly Rs.229 which sum was regularly

distributed among the poor of the City.

As this income was lost in laying the foundation, he made good the loss by assigning a similar amount for this benevolent purpose in perpetuity.

He was born on the 2oth February 1830,

Died on the 3 rd February, 1886.

There was a goodly gathering in the synagogue to hear my second address, by which I hoped to augment the response that had hitherto been made. I said that I had been told to expect a Golconda among the Jews of India, that I had had visions not merely of lakhs but of crores of rupees, but that so far my dreams had been denied fulfilment. I pointed out that the prestige of Indian Jewry was at stake, and that the forthcoming arrival of a Jewish Viceroy should stimulate their generosity to an unwonted degree, if only to show their appreciation of the honour which that event reflected upon the whole of Israel. But unfortunately the richer members of the community were mostly absent, and their poorer brethren who were present were evidently tickled by my criticism. Some further gifts, however, were offered, which showed that my words had not fallen upon barren soil; and in order that the good work might be continued after my departure I thereupon founded a Society and presented it with a Zionist flag.

The rest of the day was profitably spent in further visits, concluding with dinner at the house of the Rev. E. M. D. Cohen. There was a large family gathering around the table, for my host, having married at the early age of seventeen, had been able to enjoy the 
Psalmist's ideal of " a fruitful vine " and " olive plants." There was a long succession of Bagdadi dishes, and when we came to grace I was given a white lace cap, of the style made and worn by the Jews of Cochin, which I was allowed to keep as a souvenir.

\section{4}

The following evening I had an adventure that was quite unlike any experience that I had hitherto encountered on all my travels, and as it may throw some light upon certain types of Indian Jewry it deserves, I think, some description. It was a visit that I paid to a wealthy member of the community, accompanied by Mr. Gubbay, with the object of obtaining a big donation. I was warned that I should find the conditions in his home rather Eastern, and the monition was fully justified. As our car approached the house we heard lusty shouts coming from within, whereupon Mr. Gubbay remarked: "Ah, he's in a jolly mood: it will be all right," and as we stepped out into the marble portico we heard more shouts. We were ushered by a native servant, with turbaned head and naked feet, into a wellfurnished room, where a strange sight greeted us. In the middle of the floor lay a man, barefooted, in white pyjamas, with his head resting on a pillow and his eyes closed, as though asleep. The host, a stoutish, middleaged man, in shirt and trousers, welcomed us boisterously, and then bawled to his prostrate friend to get up. The latter at first remained motionless, but upon receiving a gentle kick jumped up with alacrity. He was a younger man, slim and sallow, with black moustache, and he bowed deferentially when introduced, saying that it was a great honour to meet me. Two other persons were present-a Bagdad Jew and a young Hindu, the latter in tight white trousers and with his coat off.

Our host shouted to the Indian servant to fill our glasses and called to everybody "Cheerio!" His friend in pyjamas at once began to ask him whether he was $\mathbf{R}$ 


\section{THE JOURNAL OF A JEWISH TRAVELLER}

going to give anything to the Palestine Fund, to which he replied: “ Don't let's talk business to-night. Let's be merry! To-day I went to the synagogue to say Kaddish, ${ }^{1}$ I did my duty, and now I'm going to be merry. Bearer ! Fill up the glasses, and cheerio !" But the other was not to be put off, and continued to reproach our host, to upbraid, to plead, to coax, and then to threaten. He worked himself up to such a rage that he flung himself upon his host and bit his ear, causing him to squeak with pain. But our host, instead of retaliating, created a diversion by asking the Hindu guest to sing. The latter cleared his throat, rested his chin upon his right hand, and then began to warble-a melancholy ditty, at first in husky tones and presently in clearer and louder accents, though the melody was monotonous throughout and interwoven with the constant repetition of a sombre refrain. But the gentleman in pyjamas was deeply moved by the Hindu song. "Wonderful!" he exclaimed. "What a voice! It is the gift of God!" And he looked quite elated as he held up his right hand to command our silent attention.

Soon after this performance dinner was announced and our host insisted upon our taking another drink before entering the dining-room. His friend readily responded and also kissed him on the cheek. We then passed into a very large and lofty chamber, occupied by a long table that was decked as though for a public dinner, and seated ourselves around it in huge leather-covered arm-chairs, which were more suitable for a club-room or a legislative assembly. Our hostess wore a loose greenish gown, which hung about her portly person like a night-dress; and shortly afterwards another lady, more portly still, arrived, likewise wearing a loose flowing gown, which, as it was white, had an even closer resemblance to a night-dress. Our friend in pyjamas made no change in his attire, but took his seat with the same grace as though clad in a fashionable dress-suit.

1 Prayer in honour of a parent's memory. 
The proceedings began by our host calling upon everybody to fill his glass and then making a brief speech : " This is the proudest day in my life, for we have in our midst the distinguished Zionist Emissary. He has come to plead for the cause of Jerusalem, and I feel for Jerusalem with every fibre of my heart. At last Jerusalem is ours and will remain ours." (Shout from the guest in pyjamas: "For ever!") "Of course, for ever! I drink to Jerusalem and to the Jewish nation!"

"How much will you give?" called out the man in pyjamas.

"No business now!" replied the host.

"How much ?" came the repeated question.

"My heart is there!" responded the host, attacking the soup.

"But your money?" came the insistent inquiry in louder tones. "How much ?" And receiving no reply, the excitable guest got out of his chair, walked up to the host threateningly, and putting his arms round his neck, bawled again : "How much ?-or I shall kill you !" But instead of killing he only kissed him, and then returned to his seat, silent, though apparently meditating a fresh attack.

The dinner was constantly interrupted by the shouting and bawling of this volatile gentleman and the countershouting of the host, as though engaged in competition; yet despite repeated provocation our host preserved an even temper. The ladies remonstrated but mildly, as though accustomed to such roysterous scenes. Several times the stormy petrel rose and administered a kiss to the different men at the table, though ignoring the women, whilst I was fortunately also spared his demonstration of affection. He then begged me to deliver a speech, but seeing that our host had no desire that I should emphasize the object of my visit, I held my peace.

Upon returning to the smoking-room our host puffed at a narghile, and his wife did likewise, whilst the rest 


\section{THE JOURNAL OF A JEWISH TRAVELLER}

of us smoked cigars. Presently the gentleman in pyjamas began disporting himself in the centre of the floor, twirling round on one foot like a ballet dancer, with one hand extended upwards and the other downwards. Then he suddenly crossed arms and legs and sat down on the floor, turning round as though for applause. There was only silence, so he rose and began again to bombard our host with the question: "How much will you give?" to which the only reply vouchsafed was: "No business to-night. Take a drink." But he was not to be deterred so easily. He put both hands on the shoulders of our host, shouting "How much ?" and then, advancing them round his throat, made as if to throttle him. Our host, who was seated all the time, had to strain every nerve and muscle to shake off his passionate assailant, who retreated disconsolate. To provide a diversion I suggested that the Hindu should sing another song. The Hindu, crossing his legs and leaning his chin on his right hand, began once more to troll forth a melancholy air, with a recurring refrain in a minor key. It acted only as a further stimulus to the gentleman in pyjamas, for he again took the floor, and, striking a dignified attitude after hitching up his trousers, he placed one hand on his heart and held the other outstretched, and then poured forth a monologue in Hindustani, of which I did not understand a single word. But Mr. Gubbay listened with rapt attention and evident pleasure. "He's a poet!" he exclaimed after a time. "It's a wonderful address on the obligations of wealth, on the necessity of devoting it to a good cause before death overtakes the rich man, for he cannot take away a single pice. Naked he comes into the world, and naked he leaves it."

The poet was apparently exhausted by his declamatory effort and sat down with beads of perspiration on his brow. The hour was late, so Mr. Gubbay and I, seeing that it was useless to pursue our quest, after the failure of the physical and poetical manœuvres we had witnessed, 
decided to take our leave. Our host accompanied us to the portico to see us into the car, but scarcely had we gone a dozen yards than we heard a fresh outburst of wild incoherent shouting.

5

I had but one more day in Calcutta, and that was partly spent in visiting the two Jewish schools. The Talmud Torah Free School was in an old building, which was in a bad state of neglect and disrepair, some of the rooms being dark on account of the defective planning. There were a few hundred pupils, whose secular education was carried on up to the seventh standard under teachers who were all born in the country. As in Singapore, they were taught to translate the Hebrew Prayer Book and Bible into Arabic, the secretary explaining that there was no member of the staff who could translate into English. The children were at school all day and were given a cold lunch every day. I was told that the institution had recently received the handsome gift of 250,000 rupees from Mr. Elias Meyer, a Calcutta merchant now domiciled in London, but I didn't learn whether any part of the money had already been spent upon it. Both the building and the educational standard were in such urgent need of improvement that I hoped the full blessing of the gift was yet to be bestowed.

The other school had a somewhat higher standard, translation from Hebrew into English being taught; but the premises were in a similar state of disrepair, and some of the rooms were also dark. It was mainly a girls' school, but there were also several boys there. I was entertained by the performance of an interesting group song with action by one of the lower classes, in which both boys and girls acquitted themselves intelligently. Neither this nor the other institution was attended by the children of the richer members of the community, as they went to private schools and then were sent to Europe to finish their education. 
246 THE JOURNAL OF A JEWISH TRAVELLER

The result of my week's endeavours was to raise 50,000 rupees-only half a lakh. But though, in comparison with the contributions of other centres, I thought this but a scanty tribute, I was congratulated upon it by many sympathizers as a success. In the evening I left for Agra, en route for Delhi and Bombay. 


\section{CHAPTER XXIX}

\section{BOMBAY}

I

7 HE compartment in which I journeyed to Agra was comfortably furnished with two cosy arm-chairs and with two big couches that could be pulled out to serve as beds, and was also commodious enough to contain all my luggage, including two large trunks, whilst in the adjoining lavatory there was a lead-lined bath eighteen inches deep. My travelling companion was a Major Cook, who told me that people travelling in India had to carry their own bedding with them, and were generally accompanied by a manservant, who prepared the bed, looked after the coupe when one was in the dining-car, saw to the luggage and swept the accumulated dust out of the carriage at every stopping-place. As neither of us had a servant, the dust that flew in through the open windows, and even through the wooden shutters, was swept out at every station by a native cleaner with a big broom, although he generally raised the dust instead of laying it. At every station, too, there were Moslem and Hindu water-carriers, to supply water to their respective coreligionists, who had their own little brass bowls. The amount of water which these bowls could hold barely sufficed to wash the face, mouth and hands: a towel was dispensed with, as the skin soon dried in the sun. On arriving in Agra, after a journey of twenty-four hours, I was driven in a native carriage through gloomy roads to an hotel. Whilst on the way I had an eerie feeling 


\section{THE JOURNAL OF A JEWISH TRAVELLER}

that there was somebody behind me, and upon looking round I saw the "syce," or footman, standing mute on the footboard at the back of the carriage.

Agra is the proud possessor of some imposing and beautiful memorials of the once powerful Mogul Empire. For several hours I paced through the palaces and mosques of the ancient Fort, a vast fortified arena filled with a wonderful little world that appeals alike to the historian, the artist and the architect. I was especially struck by the use of the traditional Jewish design of the "Shield of David"-the two intersecting triangles-in the mural adornment. At the Jehangir Mahal, dating from I566, the main entrance to the Hindu Palace has two such designs on the façade, whilst there is a large wooden gate in four panels, each of which is adorned with seven "Shields of David" in columnar form, the two upper ones in each being of scroll work. This gate, which is twelve feet high and bears an Arabic inscription in Cufic characters relating to the family of Sabuk-Tagin, was brought in 1842 by the British from the tomb in Ghazni (Afghanistan) of the famous Mahmud Yamin-udDaulah of Ghazni (999-I030 C.E.). Nor did this portal alone convey a suggestion of Semitic associations, for in a carpet-factory that I visited, and where on one side of the loom sat a man calling out rapidly in Hindustani what colours should be used, and on the other were squatted a row of boys deftly weaving the respective threads into the fabric, the rapid recitation by the man and the sing-song repetition by the boys sounded like a litany in a temple and formed a fitting accompaniment to the weaving of a praying-mat.

But that which impressed me far above all else was the Taj-Mahal-a peerless structure of majestic splendour and towering beauty, faultless in symmetry and perfect in detail. It is a wonderful creation of white marble, a glorious grouping of cupolas and minarets, of slender towers and spacious terraces, approached through a long avenue of stately cypresses, which are mirrored- 
together with the whole of the exquisite vision-in the interjacent fountains lying cool and clear in their beds of marble. The Arabic inscription on the façade of the main building is just as legible at the top, twenty feet high, as it is on a level with one's eyes, owing to the ingenious increase in the size of lettering of each line in proportion to its distance from the observer. The impressive beauty of the interior awes one into silent admiration. The tombs of the Emperor Shah Jehan and of his favourite consort, to whom the entire memorial is dedicated, are, like all the other parts of the noble fabric, of white marble, richly inlaid with precious stones. The artistic workmanship and the amplitude of design of the Taj, worthily embodying the departed majesty of the Moguls, instinctively recalled to me the glories of the Temple of Solomon, but the ancient conquerors of Palestine were not as merciful as the modern conqueror of India, and thus is the Holy Land the poorest among the lands of the East in monuments of architectural grandeur.

Another all-night journey, and I was in Delhi. The hotel to which I was recommended being full, I was given a tent in the adjacent grounds, which was fully furnished like a bedroom, with electric light and an adjoining bathroom. I had but a day at my disposal, but even in that short time I was able to get a vivid impression of the memorials and monuments of the historic city. Delhi Fort, like Agra Fort, comprises handsome palaces and stately mosques, but of all the varied wonders I beheld within its walls I was moved to deepest admiration by the Imperial baths of marble, for these were encircled by tiers of glazed niches, within which, aforetime, were placed coloured lights, so that the water falling down from above reflected the variegated hues, which were further enhanced by the dazzling gems and brilliant robes of the ladies of the harem. Evidently the Mogul Emperors were æsthetes in colour as well as artists in building. But a far more impressive scene was 
that which I was permitted to witness, after removing my shoes, in the Jamma Musjid, the largest mosque in the world : a concourse of thousands of men and women, standing devoutly in serried ranks, beneath trie noonday sun, in a vast courtyard, with their éyes all fixed intently upon the priest who led in prayer on a raised platform, and whose kneelings and prostrations were immediately followed by the genuflexions of the whole congregation.

It was a day of crowded impressions, mingled with the varied emotions and reflections evoked by a visit to the towering Mutiny Memorial, by a survey of New Delhi, which is laid out on a magnificent scale as the new seat of Government, and then by a drive in the early dusk through the ancient quarter, where lie mouldering the remains of dismantled forts and ruined villages, of silent temples and deserted tombs.

Upon arriving in Bombay, after a tedious journey of thirty hours, I was welcomed by the largest crowd that had ever assembled in any station throughout my tour. Had I been the Messiah himself, I could scarce have been acclaimed with a more effusive demonstration of joy and enthusiasm. There were men, women and children of all ages, many in festive attire, and representative both of the Bagdadi as well as of the Bene Israel sections of the community. I was greeted first by Mr. Willy Tolkowsky, the acting Belgian Consul, and member of an ardent Zionist family, who introduced Mr. D. Shellim, the president of the Zionist Association. The latter spoke some words of welcome, and then, to my astonishment, placed a large garland of flowers round my neck, whilst a little girl approached and offered me a big bouquet. Scarcely had I recovered from this-to me-unwonted mark of honour than the president of the Bene Israel Society, Dr. E. Moses, advanced, and bestowed another garland round my neck whilst also tendering me a bouquet. Encircled and encumbered with all these 
• 


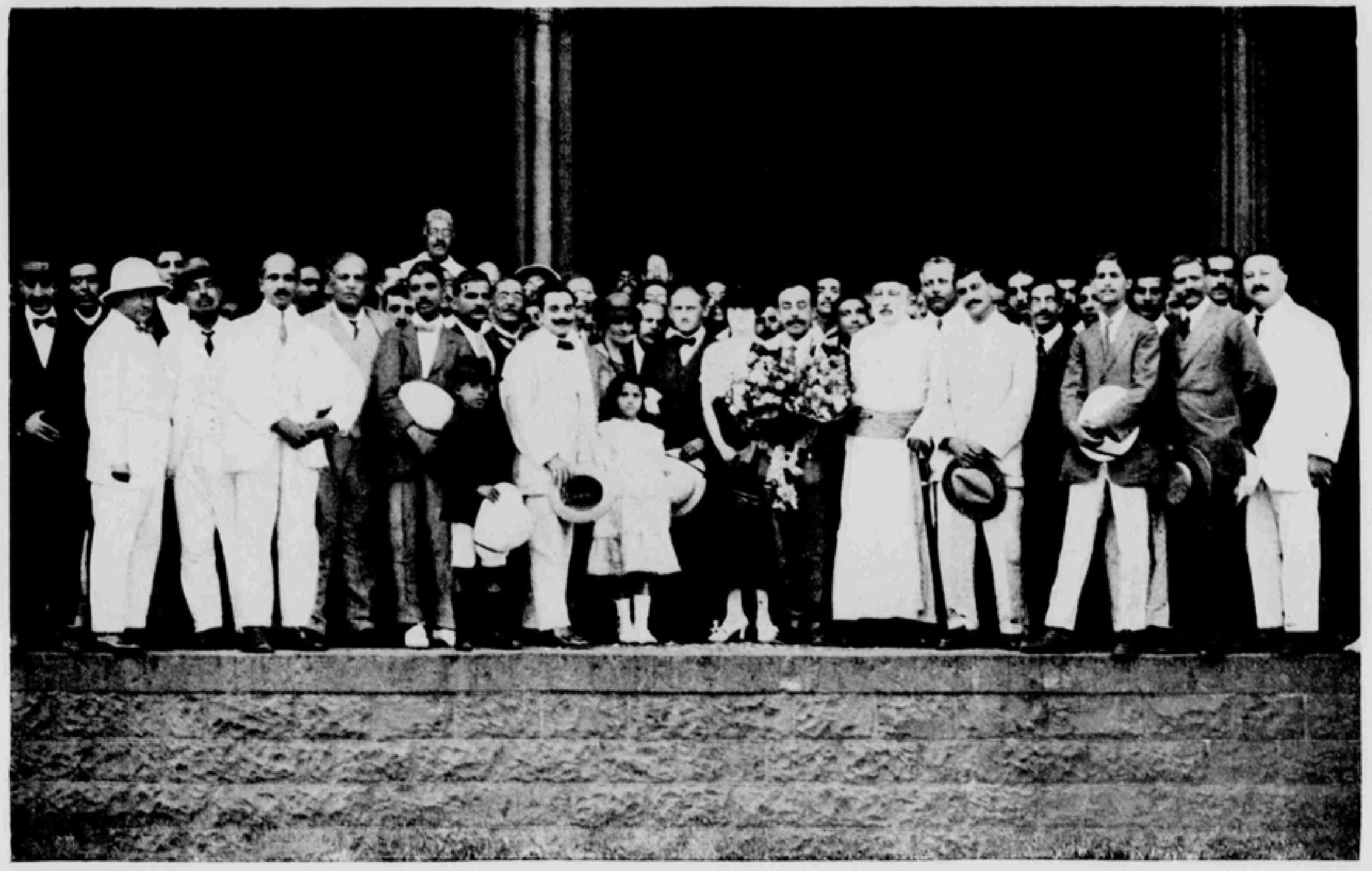


fragrant blooms, I made my way with difficulty through the jubilant throng, who grouped closely round me whilst a photographer, who had pitched his camera between the railway lines, sought to immortalize the striking scene.

A few hours later there was a gathering at the Masonic Hall, and as I entered I was greeted by a choir of boys and girls, who sang Hatikvah with a slight variation from the customary tune and with frequent repetition. The boys wore white surplices and large flat velvet hats, like that of a university provost. Mr. Shellim, who presided, addressed me constantly as "Dear brother," and after my speech, which aroused much enthusiasm, he placed round my neck a garland of silver thread which had been specially made by his wife. Then glasses of champagne were served among the elders, who, all standing, drank my health amid joyous acclaim. There could be no doubt of the sincerity of faith of those present in the dawn of a new era, but the richer members of the community betrayed their diffidence by their absence. Nor were the wealthy Jews present at the public meeting that I addressed two days later at the Jacob Sassoon Free School. This gathering, in the heart of the Jewish settlement, rather reminded me of scenes in the East End or in the Jewish quarter of a Continental city. There was a big crowd waiting for me in the school-ground, there was another crowd that blocked the stairs, whilst the third and largest crowd-noisy and excited-was already seated in the big schoolroom. There were not only men and women-some in Bagdadi costume-but scores of young children and at least a dozen infants in arms, and as it would have been impossible to make myself heard. in the joyous din I insisted that the babies should be taken out. I was at a loss to understand why there were so many juveniles, when it was explained to me that they had come in expectation of a conjuring show, which had been announced as a feature of the evening. I was at once reduced to a state of humility, but I ruthlessly 


\section{THE JOURNAL OF A JEWISH TRAVELLER}

banned the conjurers, to the undisguised disappointment even of some of the elders, and as soon as the change of programme became known there was a voluntary exodus of the youngsters. At length I was able to secure silence and give my discourse, and I was rewarded with donations to the extent of 5000 rupees. Tired out and hot, I was driven back through the swarming, sweltering native quarter to Mr. Tolkowsky's house for dinner.

In order to explain the aims of Zionism to the general public, which was prone to view them through Moslem spectacles, I arranged a meeting at the Sir Cowasji Jehangir Hall. I was anxious that the Governor, Sir George Lloyd, should take the chair, as the Governor of Hongkong had presided at a similar gathering, but he informed me that he could not do so without consulting the Council, for which, however, there was no time. But Providence provided an excellent chairman in Professor Patrick Geddes, the Director of the Department of Sociology at Bombay University. He had been my first guide in Jerusalem nine months before, where he had been working at the plans of the Hebrew University, and he rejoiced at the opportunity of being of further service to the cause. I found him in the College of Science, a building of imposing dimensions, which made me at once revise my conception of Indian seats of learning. He was busily engaged, with the help of some pupils, in packing up his multitude of papers, which were distributed over a score of tables and benches, for he was sailing for England four days later on the China, on which I had also secured a berth. As the meeting was convened at very short notice it was impossible to expect a mighty throng, but happily the audience, which half filled the great hall, contained a great number of Moslems and Parsees as well as Jews. It was difficult to speak amid the noise of the traffic, which resounded through the open doors, and the whirring of the electric fans, but the effort was not in vain, as another 5000 rupees were subscribed, including contributions from 
some non-Jews. Professor Geddes set the example of writing a cheque on the spot, and after the meeting he explained to a number of interested sympathizers his drawings and sketches of the Hebrew University, which were attractively displayed in front of the platform.

In Bombay I felt even more keenly than in Calcutta the lack of proper communal organization. Not only was there a wide gulf between the Bagdadi Jews and the Bene Israel, the former looking down upon the latter as people of an impure and inferior stock, but the Bagdadi section seemed to be without any head. Gone are the days when the Sassoons, those merchant princes, who have not only created prosperous banks and businesshouses, but have given a powerful stimulus to the commercial development of the city, were content to live in the scene of their first financial exploits. They have been lured to the greater world of the west and made their homes in London, and their passing has left the Bombay community orphaned. Their business offices, David Sassoon and Co. and E. D. Sassoon and Co., are still here as before, their affairs in the able hands of trusted directors, who also have the stewardship of the communal benefactions left by the pious founders, but the paternal solicitude shown by the former generation is scarce compensated by the flying visits of the members of the present generation. Fortunately one such visit, that of Captain E. V. Sassoon, head of E. D. Sassoon and Co., coincided with my own, with the result that after a couple of interviews I received from his firm a cheque for $£$ rooo (thus balancing the gift of a similar amount from D. Sassoon and Co. in Shanghai). It was a notable cheque, for it bore the name of the firm not only in English but also in Hebrew-a vivid reminder of the days when all its correspondence was conducted and its books were kept in the holy tongue.

The most distinguished resident Jew was Sir Sassoon David (Sassoon being a common forename among Eastern Jewry), whose commercial shrewdness had won 


\section{THE JOURNAL OF A JEWISH TRAVELLER}

him a fortune and whose princely gifts of buildings and monuments to the city had procured him a baronetcy. He was the chairman of various big companies and banks; he had been chairman of the Chamber of Commerce, and he was always to the front in every municipal undertaking. He was chosen to present the city's address of welcome to the Prince of Wales, and later to present a similar memorial to his illustrious co-religionist, the Earl of Reading, upon his arrival as Viceroy. But he turned a deaf ear to the cause I pleaded. I found him genial and talkative enough as he sat, an elderly, olivebrown figure, in a dark blue suit and white waistcoat, behind his desk in a small plain office, above which he lived, but though he expressed pleasure at seeing me, he bluntly declared that he could hold out no hope of helping. He said that it was against his conscience, his religion. I asked him to quote me a text or law to substantiate his standpoint, to which he replied that he might be wrong, but he could not at his age change his opinion. I told him that even Christians had given. "Yes, and so would I if I were a Christian," he said quizzically, " but being a Jew, I can't."

"But explain how it is that you can't, and I shall help you over your difficulty," I urged.

"Oh, you want to convert me! I don't want to be converted. I may be wrong, but I stick to my opinion."

But though, even after a second interview, I failed to obtain a cheque from this merchant prince I was given a precious little document of which he was the creator. It was unique among the literary exhibits of modern Judaism, for it was a tram ticket specially printed for the use of Jews only on Sabbaths and festivals. Riding on those sacred days is taboo for the orthodox Jews, as it necessitates the handling of money even if it does not involve any forbidden work; and hence the Jewish baronet, as chairman of the local electric tramways company, was inspired with the idea of devising the 
following ticket, which could be bought by his observant coreligionists before the days on which it was to be used:

\section{The Bombay Electric Supply \& Tramways Co.,}

ONE ANNA TICKET COUPON

Ltd.

\section{FOR JEWS ONLY.}

No.......................

(Good only for Sabbath \& Holidays.)

To be handed over to the Conductor who will issue a ticket in lieu thereof.

Initials.

C. LUCAS, Asst. Manager.

Two years later another Zionist emissary, Madame Pevsner, visited Bombay. She was destined to reap what I had sown, for Sir Sassoon David headed the list this time with a cheque for 5000 rupees.

3

The greater and the older part of the Jewish population in Bombay consists of the Bene Israel, who, owing to their obscure history and their resemblance to their Hindu neighbours, are regarded by their Bagdadi brethren as of alien stock. Their history cannot be traced back further than the middle of the eighteenth century, but their traditions and customs point to a much more ancient origin. They claim to be descended from the survivors of a band of Jews who fled from persecution in Palestine I800 years ago and who were wrecked near the Henery and Kenery Islands in the Indian Ocean fifteen miles from Cheul, once the chief trading centre between Arabia and India. The survivors are said to have been seven men and seven women, whose numbers may suggest romance 
though not necessarily fiction. The evidence in support of the antiquity of the community consists of the fact that the first generations were ignorant of the feast of Hanucah and of the destruction of the Second Temple, that they observed many rites and ceremonies current in the times of the Mishna, and that they made offerings with frankincense. One of the writers of the Bene Israel suggests that their ancestors left home about the time of the invasion of Antiochus Epiphanes (I75 B.C.), and that they came to India either through the Gulf of Suez or through the ports of Elath or Ezion-Geber, which were opened up for commerce with India by King Solomon. The Bene Israel now number some 15,000 , and the explanation they give for not having increased to a greater extent, assuming that their community is as old as they maintain, is that during the greater part of their history they were exposed to the ravages of famine, disease and persecution.

There are two reasons advanced for the name of Bene Israel. One is that these Jews, being unable to prove their lineage from the tribe of Judah, owing to their historical records having perished, adopted the name of "Children of Israel " as signifying their descent from one of the Lost Ten Tribes. The other is that they avoided the name of Jews, because it was unpopular among the Moslems, and assumed the name of Bene Israel because of the favourable use of this term in the Koran. Originally they were known by the Hindustani designation of "Shanvar Telis" or "Saturday oil-pressers," because their principal occupation was oil-pressing and Saturday was their day of rest, whilst they assumed Hindu names to avert suspicion and even adopted some local customs. They had neither scrolls of the law nor liturgy, and knew only the "Shema,"1 until, according to their tradition, there arrived in their midst in the year 1000 a religious teacher named David Rahabi, who was believed to have come from Egypt, and who taught them the

1 Deut. vi. 4-9, xi. 13-2I, and Num. xv. 37-4r. 
tenets of their faith. Thenceforth there was another great gap in their history, for it was not until early in the nineteenth century that we hear of religious leaders coming to them from Cochin.

But although timidity seems to have been one of their characteristics whilst their community was still young, they have nevertheless produced a great number of soldiers, many of whom have been distinguished for their gallantry and valour. Their military record is, indeed, illustrious. Many of them served faithfully in British Indian regiments for very long periods, even as long as forty and fifty years; several rose to the position of Native Commandant ; and many fell while fighting in the Mysore and Marathi wars, others in the Sikh, Persian and Afghan wars, and others again in the Indian Mutiny and in the Suakim and Soudan expeditions. During the second Mysore War (I780-4) several of the Bene Israel who had fought for the East India Company were taken prisoners by Tippoo's army, and were released in consequence of the intervention of Tippoo's mother, who begged her son to spare the lives of the Bene Israel spoken of in the Koran. The most distinguished of these captives was Samuel Ezekiel or Samajee Hassajee Diveker, who enlisted in I750, rose from the ranks to the position of Native Commandant of the 6th Battalion, and served under General Matthews in the second Mysore War. $\mathrm{He}$ was kept a prisoner for two years by Tippoo Sahib, and after his release, as a thankoffering unto the Almighty, built the first Bene Israel synagogue in Bombay in I796.

I found the Bene Israel animated by a keen Jewish consciousness, by a love for Jewish learning, and by a strong desire to take their share in the national task of restoring the Land of Israel. I came into close contact with them at a social gathering that they held in my honour, and saw by the way in which they were seated that they were still influenced by Oriental ideas, for they were ranged round the room in four main groups : first, the elderly men seated together, then the married women, 


\section{THE JOURNAL OF A JEWISH TRAVELLER}

next the young women, and, lastly, the young men. It was at first a little trying to carry on a conversation with one or two members of one group, whilst all the rest of the company looked on in respectful silence, and then to pass on to the other groups for the purpose of question and answer, but I soon adapted myself to the novelty of the situation. The women, who were all dressed in the same style as Hindu women, were far less talkative than their Western sisters, the only member of their group essaying to speak being an intelligent young lady who had graduated at the Cambridge University. The most loquacious were the young men, who asked many questions about the developments in Palestine and especially about the relations between Jewish nationality and the citizenship of the countries in which Jews lived. One of them, with an earnest pensive look, urged that the tendency of political thought was to eliminate nations, that there was going to be one world-family, and therefore asked: Why work for the regeneration of the Jewish nation in Palestine? I assured him that the tendency of which he spoke was unknown to the statesmen of Europe and had not the remotest bearing upon the aims of Zionism, but he received my reply with the scepticism of one convinced of his own infallibility. Our discussions were interrupted by a brief musical programme : a selection from Il Trovatore on the violin, a Marathi song about Krishna sung by a girl sitting and without accompaniment, and then a monotonous and melancholy performance on a native instrument. When conversation was resumed I learned that there were two rival tendencies among the Bene Israel, represented by the League and the Conference (their respective forms of association), the one emphasizing higher and the other elementary education. They boasted, moreover, of two different organs, The Friend of Israel and The Israelite, printed partly in English and partly in Marathi, and also of a well-compiled Year Book. At the end of an instructive evening I was garlanded, and then taken home in a car 
through sultry, dusty roads, whose pavements were already strewn with the motionless forms of scores of natives sleeping outstretched with scanty covering or none.

The following evening I addressed a public meeting of the Bene Israel at the Israelite School. There was an attendance of 500 , and the decorum was most exemplary. Dr. E. Moses, who presided, referred in his opening speech to the " colour bar" that, he said, had been raised against the Bene Israel by the other Jews in India, and inquired whether any such discrimination would be made against them in Palestine. I assured my hearers, in what was the last address of my mission, that they need not have any such fears, that they would be just as welcome as the Yemenites or any other Eastern Jews who had recently arrived in Palestine, and that their services could be utilized with advantage as engineers or skilled artisans, or in other capacities. They followed my discourse with the keenest attention, and my appeal aroused an enthusiastic response, beginning with a gift of 1000 rupees and exceeding ultimately eight times that amount, in addition to a handsome gold ring. Although not the most fruitful, it was nevertheless the finest meeting that $I$ addressed in India, and the impression of its ardour lingered gratefully in my mind as I was driven home past a native procession, in which a small idol of Krishna was being carried beneath an umbrella, with a thunderous band and flaming torches, from one temple to another.

One afternoon I paid a surprise visit to the Jacob Sassoon Free School, one of the various foundations dependent upon the bounty of the Sassoons. The first room that I entered, in a detached part of the building, contained a large class of young unruly children under the charge of a grey-bearded Haham - their Hebrew teacher. Several youngsters at once ran out of the class and looked at me with curiosity. Their doddering master was unable to restrain them, nor did he seem to understand me when I asked him where to find Mr. Shellim. I then went to another class, which was under the charge of a 
young woman, and a sharp-eared boy volunteered to guide me. We discovered Mr. Shellim in the school compound, making arrangements for the sheltering of a number of Jewish refugees who had come from Anatolia. There were some forty-five altogether-men, women, children and babies in arms, all dirty, dusty and bedraggled. They said that they had fled from the Bolsheviks, who had dispossessed them; that they had first travelled to Basrah, whence they had been sent on to Bombay; and that they were now anxious to go to Palestine. There were also a few Jews from Persia, including a Hebrew teacher and his two young sons with tousled mops. They were all in a pitiable plight and gathered round me beseechingly, appealing to me to cable to the Government in Jerusalem to send a ship to convey them to the Holy Land.

Accompanied by Mr. Shellim, I entered the main. portion of the school and met the head master, Mr. E. M. Ezekiel, a cultured and genial grey-beard, and a member of the Bene Israel, who also holds the position of Professor of Hebrew at St. Xavier's College. Under his guidance we visited all the rooms, the ages of the pupils ranging up to eighteen. I was struck by the small attendance in certain classes, whereupon Mr. Ezekiel told me that many children were absent because they were helping their parents in making preparations for the celebration of Purim, although this festival was not to take place for some days. He also said that children were often away on Friday in order to help in the Sabbath preparations, that some were even addicted to gambling, and that he had a hard struggle to make the parents send them regularly to school.

Upon emerging once more into the compound we were approached by the two Persian boys, who, under the stimulating glance of their father, at once began singing a song in Judeo-Persian for my entertainment. The proud parent told me that it was his own composition : it was a song about the restoration of Zion, in which I 
noticed in the recurring refrain the significant rhyme of "Zi-ōn" and " milli-ōn." There seemed to be countless verses, and judging by the ease and rapidity with which the boys rattled them off, to a somewhat monotonous air, I could not help thinking that they must have recited them some hundreds of times in the course of the long journey they had made since leaving home. The throng of refugees stood around with admiring looks, which only served to egg one of the boys on to quicken his rate of recitation, until I began to fear that he might lose his breath. At length the wondrous narrative came to an end, and I rewarded the boys with a couple of rupees, which were promptly annexed by their vigilant father. One of the refugees-a middle-aged man with matted beard and wild-looking eyes-was demented: he made several desperate attempts to approach me, but was forcibly held back by his companions.

Mr. Shellim showed me the tents that he had roughly fitted up for these unexpected guests, and then invited me to have tea at his home, which was situated over his tinplate works, close to the school. He there introduced me to a lady as his "Memsah'b Number One," and smilingly said that his "Memsah'b Number Two" was in the other room. His first wife, whom I saw, was a Bagdadi Jewess; his second, whom I did not see, was an Englishwoman, who had exchanged her Christian faith for Judaism a couple of years before her marriage. It was the only case of a Jew openly living with two legally wedded wives that I came across in the whole of my tour.

The following day I visited the school of the Bene Israel, which is maintained by grants from the local "Gates of Mercy" Synagogue and from the AngloJewish Association. I had a talk with the principal, a Hindu, who showed me over most of the class-rooms and speedily arranged a drill display by boys and girls, among whom I noted several non-Jewish children: and then I spent some moments with a Hebrew class, 


\section{THE JOURNAL OF A. JEWISH TRAVELLER}

which was conducted by an old Cochin Jew, whose face was of yellow parchment and whose round cap was of embroidered satin, and who had patiently initiated thousands of tender pupils into the difficulties of Hebrew reading during the last forty years. The headship of the school has since been made over to a talented Jewish young lady, Miss E. Reuben, who graduated at Cambridge. There were two other institutions of the Bene Israel, to which I was introduced. One was an orphanage that had just been erected for the accommodation of forty inmates: the cost of building had been generously provided by a member who had mortgaged his house to raise the requisite amount, whilst the cost of maintenance was to be furnished by the rents of the shops that were being installed on the ground floor. It was an establishment, the like of which was not possessed by the local Bagdadi community, and which indicated the existence of a healthy spirit of initiative and self-help. The other institution was the library and reading-room of the Israelite Brotherhood, which contained a good collection of modern Jewish books and newspapers, and which bore eloquent testimony to the desire to enter into close communion with the thought and aspirations of the children of Israel in Western lands.

But of all the things and people that I sawin Bombay by far the deepest impression was produced by two Jewish carpet-dealers from Meshed, who related a story of the persecution of their brethren in that Persian city which transported me to the days of the Spanish Inquisition. They told me that Jews had been living in Meshed for the last 200 years, and that their oppression had begun some eighty years ago in consequence of some Jews having killed a dog on a holy day of the Shiites, in the days of Nasr-eddin Shah. As a reprisal for that offence thirty-six Jews were killed on the same day, and the whole community were compelled to declare 
themselves and live as Moslems. The Shiites took effective steps to force the Jews in Meshed to observe the Shiite religion, for they built a mosque with Jewish money in the Jewish quarter, in which the Jews had at first to pray every day but later only ten nights in the year, on the festival of Moharam. These victims of Moslem fanaticism were thus obliged to live like the Marannos in the intolerant days of mediæval Spain. They have built five subterranean synagogues, in all of which they pray daily, and also a subterranean Hebrew school (Talmud Torah). The community now numbers 2500 souls (some 800 heads of families), and it has a Rabbi and several Shochetim and Mohelim. Some thirty years ago several Jews from Meshed fled to Russian Turkestan and lived at Merv, near Bokhara, until, four years ago, the Bolsheviks swooped down and plundered them, killing two of them. Thereupon the survivors, despoiled of all their possessions, fled in poverty and despair back to their brethren to seek safety and solace in the underground shrines of Meshed.

The two carpet merchants dispelled any suspicion that they might be romancing by showing me their passports, in which they were entered with Moslem names and described as of Mosiem faith, and by speaking fluent Hebrew. And one of them, at my request, and under my eyes, wrote out a brief statement in Biblical Hebrew, which is at once a record of human cruelty, misfortune and indomitable faith. The document runs as follows :

" Behold, we make known unto you in short the things that have happened to us, for we are of the forced converts of Meshed. For it is nigh upon eighty years that they have forced us to observe the faith of Islam, but in secret we are Jews and keep the Jewish religion in secret. Because we did not wish to profane our religion, many of us journeyed to Russia and there we traded in commerce, and there was no poverty in our midst. But after a time Russia became Bolshevik, and they spoiled us. We returned again to Meshed with empty hands, 
and we were afraid to reveal ourselves, not because of the Government but because of the people, for if it were known to them that we were Jews they would kill us in a moment, for they are wild and it were not possible for the Government to defend us. Now most of us desire to journey to Jerusalem, but they are unable to do so because they have become poor. And therefore we ask of you that you shall find a healing for our sufferings, for the sages have said: "Whoever restoreth the life of one in Israel is as though he had restored the whole world.' For it is a time of distress unto us. Hasten unto our help and devise according to your wisdom, so that, Heaven forbid, there shall not befall us any danger."

The carpet merchants, I was told, came periodically from Persia to Bombay with a large assortment of attractive fabrics, woven by Jewish hands, which they had little difficulty in selling. There were some with striking designs, including legendary portraits of Moses and Aaron, and also of Moses Maimonides, and when I observed that I did not think it seemly that the features of these saintly men should be exposed to being trodden upon, they smilingly assured me that those carpets were not intended to lie on the floor but to hang on the wall.

\section{5}

It was with no small feeling of relief that I boarded the China for my return to Europe, for after nine months of incessant travel over such vast distances and in such varied climes-apart from my propaganda work and money-collecting-I was not a little tired. Before leaving the wharf I was garlanded twice more, and therefore hastened up the gangway and sped to my cabin in order to divest myself of the embarrassing blooms. The ship was packed, for it was the season when officers and officials with their wives and families rushed to England for a coveted holiday. Our most distinguished passenger was the Maharaja of Patiala, in whose honour twenty-one 


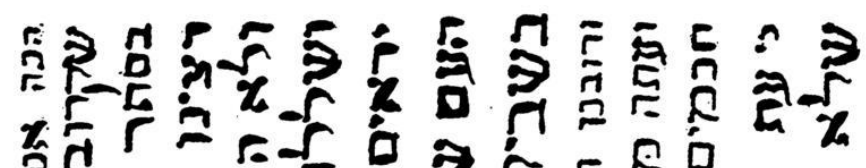

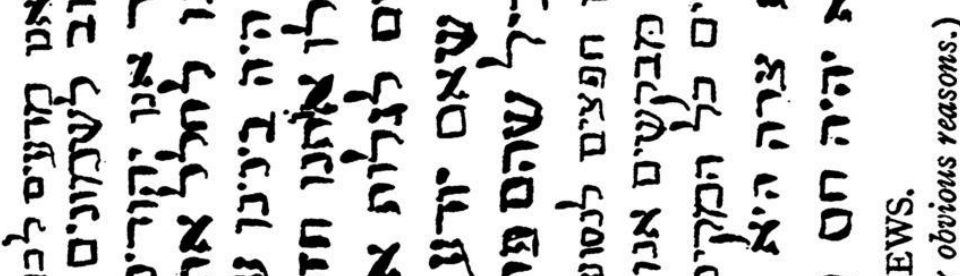

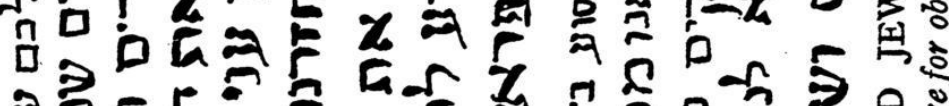

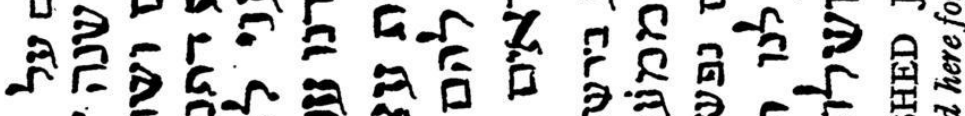

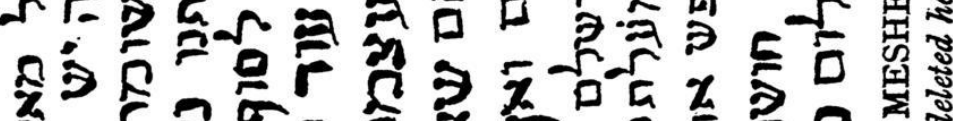

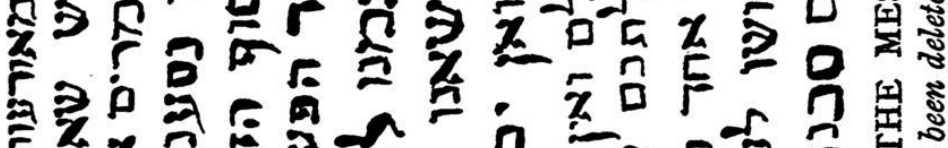

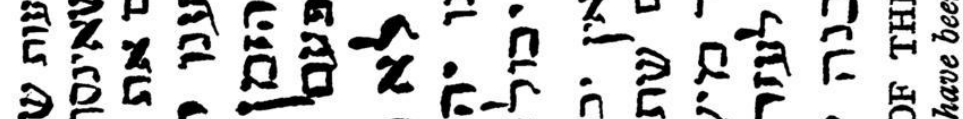

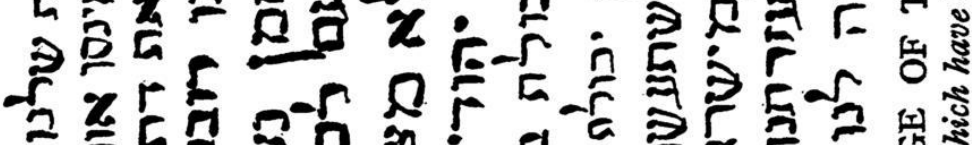
2

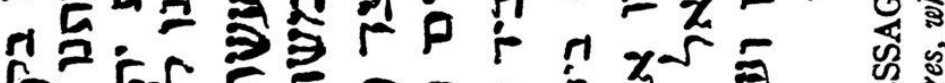
- Eor ro

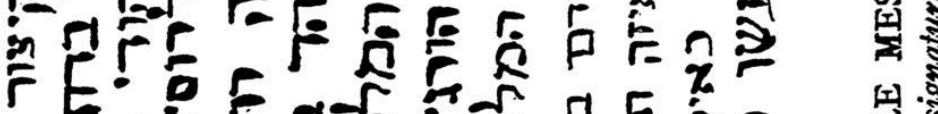

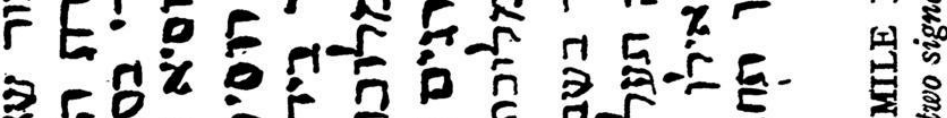

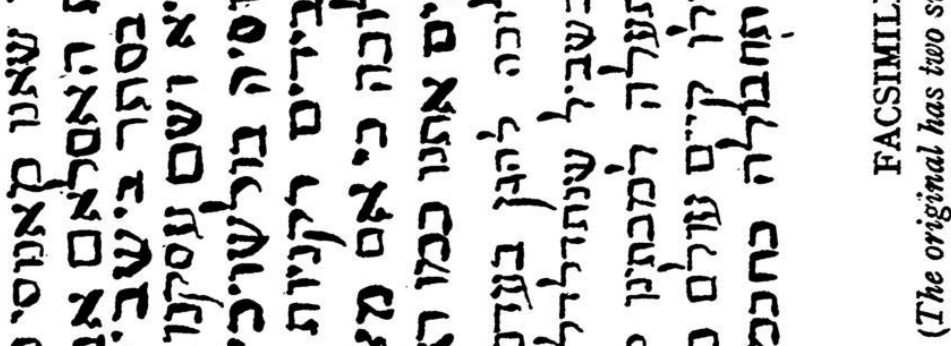

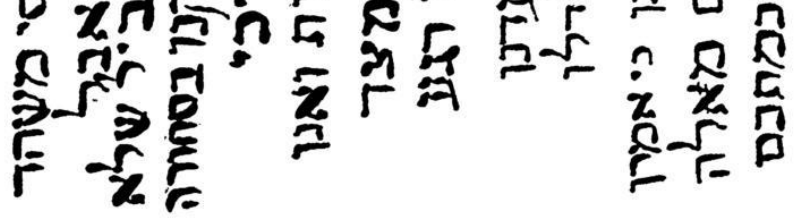


guns boomed forth as we set sail. He is a striking figure, tall, massive and bearded, with contemplative eyes, and speaks English with a most agreeable accent. He told me that he had spent several months in Palestine, where he had fought at the head of 30,000 of his troops, and he inquired with friendly interest after the progress that had been made in the country.

I had hoped that we should put in at Aden, so that I might have the opportunity of visiting the local Jewish community, whose leader, Mr. Mesa, I was told, was a man of great wealth, controlling most of the trade between the interior of Arabia and the Soudan. But unfortunately we reached Aden late at night, and halted only for a couple of hours for the purpose of taking on board the Governor of the Seychelles and one or two other passengers. A few days later, midway in the Red Sea, we passed at midnight the ship that was taking the Earl of Reading, the new Viceroy, to the scene of his administration. A message of good wishes had been signalled to him from our vessel before we retired to sleep, and the following morning, as we trooped down to breakfast, we found a cordial acknowledgment posted on the notice-board.

A day before we reached Suez, at the suggestion of Professor Geddes, who was never happy except when busy doing things and stimulating others to equal industry, I gave an address after dinner to my fellow-passengers on the subject of my mission. Many of my hearers were Government officials from India, who followed my remarks with close attention and afterwards put various questions. It was the last discourse that I held before reaching Europe, delivered in the inspiring vicinity of the Holy Land, perchance not far from the very spot where the Children of Israel crossed over in their flight from the land of bondage to the Land of Promise. 


\section{CHAPTER XXX}

\section{PALESTINE REVISITED}

I

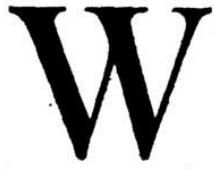

HEN I visited the Holy Land for the first time, two months after the historic decision of the Peace Conference at San Remo, that a National Home for the Jewish People shall be created in Palestine, it was still described and treated as " occupied enemy territory," though no enemy of any consequence could anywhere be seen. It was under the administration of G.H.Q. at Cairo, whence dozens of "red tabs" travelled daily in a comfortable dining-car across canal and desert to Jerusalem. The mere civilian needed a military permit to enter the country, and he had to show an unblemished record and weighty reasons, and then wait several weeks in tantalizing suspense, before he obtained the precious pass.

Within the Promised Land there brooded an air of stagnation and suppressed nervousness, tempered by a note of expectancy, for trade and commerce were paralysed by the military edict forbidding all land transactions pending the creation of the civil government. The only event that had ruffled the serene and solemn calm of the Sacred City was the violent assault made by the Arabs, in celebration of their Nebi Musa festival, upon the Jews, an outrage that cost six of them their lives and caused the imprisonment of eighteen others for the crime of self-defence. ${ }^{1}$ I saw the Jewish prisoners in their stone cells in the mediæval fortress of Acre, watched over by British soldiers with fixed bayonets-a strange inaugura-

1 April, 1920.

267 
tion of the Jewish National Home, which the British Government had promised to use its " best endeavours" to establish.

But there was a note of expectancy in the air. It could be felt from Dan to Beersheba, in the towns and villages, above all in the Jewish rural colonies, and even in the mouldy cells of the mediæval fortress of Acre. For within a few days the High Commissioner appointed by Great Britain as the Mandatory Power was due in a warship in the Jaffa harbour.

After the lapse of nine months I was in Palestine once more. I had spent the interval in visiting nearly all the Jewish communities east of Suez, from Bombay to Sourabaya, from Singapore to Harbin, from Yokohama to Sydney and from Perth to Dunedin-expounding the significance of the San Remo decision and heralding the blessings of the British Mandate. And I returned to see what changes had taken place. I found that the control of Egypt over Palestine had apparently ceased, that even the close link provided by the convenient railway bridge across the Suez Canal had been snapped, so that one had to walk across a floating wooden bridge, and that the ordinary visa at Kantara was the only permit required. But it was really an extraordinary visa, for it was written in three languages-English, Arabic and Hebrew. Therein I saw the first sign of the evolution of the Jewish National Home, for after nineteen centuries the language of King David had once again been invested with official dignity in the land of its efflorescence. And that same sign, in the days that followed, manifested itself in a multitude of forms throughout the country. Not only the written, but the spoken word too prevailed everywhere, for Hebrew had become a living tongue in Palestine even before the war. But not until now did one find Hebrew names, inscriptions and announcements printed and displayed so systematically and profusely, for wherever there was an English or Arabic legend, there too was a Hebrew equivalent-in Government buildings and on municipal 
notice-boards, in railway stations and post offices, in streets, shops and hotels, and even on the primitive motor-bus (transformed from an army lorry) which ran from the Post Office Square in Jerusalem to Government House on the Mount of Olives. Even the postage stamps and railway tickets bore a Hebrew superscription, whilst the lengthy laundry bill of the Hotel Allenby contained the names of the most fashionable and recondite articles of underwear in the language of Isaiah. And if one bought either of the two Hebrew dailies published in Jerusalem, one could find in the advertisement columns testimony enough to the up-to-date adaptability of the ancient tongue.

\section{2}

The other most striking evidence of progress, apart from the structural extensions and improvements at Ludd Junction, consisted in the groups of bronzed and brawny young Jews whom I met in different parts of the country, engaged in various kinds of outdoor labour. They were the Haluzim, or pioneers, who had come from the lands of oppression and outrage in Eastern Europe to help in the upbuilding of their ancestral country. They showed neither the bent back nor the hunted look conventionally associated with the children of the Ghetto. Their sturdy frames and fearless gait, stiffened in the wars they had fought for other nations, proclaimed them doughty builders of their own National Home. Some 4000 had arrived during the last few months, most of them after enduring the bitterest hardships and overcoming the most perplexing obstacles, from the shores of the Black Sea and the shambles of the Ukraine. They were not workmen of the common order, for many of them had been students training for doctors and lawyers, dentists or engineers, their academic career cut short by the anti-Semitic rectors of reactionary universities, and their individual ambitions all sacrificed upon the altar of national restoration. 
270 THE JOURNAL OF A JEWISH TRAVELLER

Travelling towards Ludd, the rapidly growing junction of Southern Palestine, I beheld from my carriage-window the first big group of these Haluzim, many of them bared to the waist, working like navvies-though with greater diligence-at the making of a white stone road, one of the many roads wrought by them and their comrades during the preceding months. I saw these pioneers laying a railway line to the wine-growing colonies of Rehoboth and Petach Tikvah, setting up telephone-poles between Haifa and Ludd, excavating the famous pools of King Solomon for future reservoirs, and planting trees on the spacious summit of Mount Carmel. They lived simple and laborious lives, sleeping in huts and tents, and rising with the dawn, yet rejoicing in the hardness of their lot, which they sweetened with snatches of song.

Among some of the groups there were also young women and girls, robust and tanned, who shared in the toil of their comrades and saw to their bodily comforts. In Jerusalem I met a young Jewish typist from Liverpool who chafed against the monotony of her daily work and longed to break stones for the roads, so that she might feel that she was, indeed, taking a part in the actual rebuilding of the New Judea. Nor was her case unique.

The most impressive piece of work that the pioneers had already accomplished was the creation of the little settlement at Dilb, half an hour's drive from Jerusalem. Upon my first visit I saw a score of young men and women removing stones and pulling out weeds from a rather hilly and apparently intractable tract of land, bearing remains of terraces that were 2000 and even 3000 years old. It was a tedious task, without a glimmer of promise. After nine months I found there an almost finished estate of nearly 250 acres, comprising all manner of cultivation, with the terraces rebuilt according to their original design. The hills had been planted with 120,000 forest trees-casurinas, pines, cypresses and eucalyptus. There was an acclimatization garden containing a hundred varieties of fruit-trees, amongst which predominated figs, 
peaches, apricots, cherries, plums, pears and apples, some thousands in all. There were also 20,000 vines, including the choicest types from France, Palermo and California. And there was, further, a poultry and dairy farm, with thirty beehives and sixteen head of cattle, soon to be greatly increased. All this had not been accomplished by the original group of twenty. For five months ten score pioneers had toiled at preparing the land for cultivation, constructing terraces and building a road nearly a mile long; and now there was a settlement group of forty occupying five wooden barracks, and an afforestation group of thirty living in tents. Within two or three years the entire area of Iroo acres, which belongs to the Jewish National Fund, will have been reclaimed, settled and afforested, providing a livelihood for I50 families; and, the agricultural colony once established, there will grow up around it an urban settlement, which can be fashioned after the manner of a garden city. The land has been leased for three years to the settlers, and the cost of its cultivation and development has been covered by a loan from the Zionist Commission, which, provided the estimated progress is made, they are expected to begin repaying after the third year.

The colonists themselves produced a gratifying impression of healthy and happy pioneers-conscious of the importance attaching to their undertaking, and especially to its success. I visited them one Friday afternoon, when they finished work earlier because of the incoming Sabbath, and as I stepped into one of their barracks I was greeted by the welcome fragrance of the delectable dishes baked in honour of the day of rest. Some doctors had come from Jerusalem to inquire after the health of the settlers and to investigate the question of installing a modern water supply. The Agricultural Director of the Palestine Government was also there, and we traversed a great deal of the plantation together. The scene evoked his expert approval; it aroused my sincere admiration. This infant village, nestling so pleasantly 


\section{THE JOURNAL OF A JEWISH TRAVELLER}

in a verdant valley, with its symmetrical terraces of young vines and its orderly fields of fruit-trees, is the creation of youthful pioneers who, until less than a year before, were pining away in the dismal Ghettos of intolerant Poland. Within a brief space of time they have found happiness and made the deserted plains of Judea smile again. And with the coming of myriads of their comrades from their ungrateful motherlands, what wealth of fruitful toil may they not spread around them in the unfolding future!

\section{3}

Apart from the work of the pioneers there were but few signs of progress. The broad-gauge railway from Jerusalem to Jaffa, along which the High Commissioner drove the first train, was perhaps the most notable. But other public works were still in the stage of incubation. Engineers and architects were putting their heads together and drawing up attractive plans for official inspection and approval, but even the best laid plans, one heard, would have to tarry patiently for execution. There were designs for the construction of a harbour at Jaffa, where immigrants were roughly landed in native boats, and also for the much easier development of a port at Haifa, which was blessed with a commodious bay and destined to become the chief commercial haven in the Levant. Even now some huge engines brought from Austria for a cement factory could not be landed at Jaffa and had to be conveyed further to Haifa, whence they were afterwards transported southward by rail. And then there were brilliant schemes for the utilization of the Jordan waters for an electric power station and for irrigation-schemes that had been approved and glowingly commended by the most critical engineers and scientists. But so far no steps could be taken for the realization of all these momentous and lucrative projects, because of the lack of money. The Palestine Administration intended issuing a loan for some of these under- 
takings, but not until the terms of the British Mandate had received the seal and blessing of the Council of the League of Nations could the Government address itself to this needful measure. 1

The dearth of dwellings was the burden of many a complaint upon my first visit; upon my return the complaints seemed more numerous and clamant. Houses were crowded, rents were high, settlers were multiplying, yet no attempt appeared to be made to grapple with the growing problem. In various quarters of Jerusalem there were many half-finished houses, without an upper floor, or without roof, windows or stairs, which had been begun before the war and then left derelict, to become the receptacle of refuse and the haunt of wandering cats. The completion of these houses was suspended, either because the owners had been scattered by the war, or because there was no money, or because no building could be set up before it had passed a committee that was charged with the orderly development of the city, and which seemed to reflect that, as Rome was not built in a day, Jerusalem need not be rebuilt in a year. But the principal stumbling-block was undoubtedly the lack of money. In other countries, if one possessed even half of the sum requisite for buying land or building a house, one could borrow the other half upon reasonable terms from a bank. But in this country, wherein the Jewish National Home was to be built, there was as yet no bank that could advance a mortgage. The capital of the Zionist Bank, which ignorant critics magnified beyond measure, was still very small and must be reserved for other important things. And even though a bait was held out to investors in the protection of capital from taxation for the next few years-since it was impossible to ascertain the wealth of Arab merchants and landowners, and it would obviously be unfair to tax only the

1 The mandate was formally ratified by the League of Nations on July 24th, 1922, and came into full legal operation on September 3oth, 1923. 


\section{THE JOURNAL OF A JEWISH TRAVELLER}

wealth of those who did not conceal it-there were still no tidings of an influx of gold. Of men there was no dearth: nay, there were hosts that would gladly come in endless stream, but their coming was subject to careful selection. But as for money, that wherein Jews were fabled to be richer than all other people, it trickled through very slowly and sparsely. And that was why so many grandiose conceptions, which must fire the imagination of the most sluggish, were still so remote from realization. The Technical Institute at Haifa, though almost completed on the eve of the war, still remained as it was then, without doors or windows, the wind from the sea howling through the corridors and sending up clouds of dust. The Jewish National Library was tucked away in a little building with a little insignificant door, where the librarian complained that he had no money either for binding books or for making shelves upon which to place them. And the University of Jerusalem, of which the foundation stones had been laid over three years before in a scene of impressive ceremonial, ${ }^{1}$ had not emerged an inch above the ground. Even the care of the sick and the relief of the poor were crippled through shortage of funds, and a Jewish hospital in Jaffa had to be closed.

4

If there was any phase of activity that was marked by unalloyed progress it was the activity of the schools, which hummed with the voices of young Israel freely speaking the language of ancient Israel. Love of learning, rather than the typical diligence of the modern pupil, was the quality that most distinguished the youthful students. They probably had fewer text-books than any other students in the world, for every subject was taught in Hebrew, but there were still many subjects of which text-books in Hebrew had not yet been printed, and the teacher worked out his lessons from day to day. But

1 I9r8. 
there was one subject, the geography of the Holy Land, which they did not learn merely from books and relief maps, but much more from rambles under the guidance of an enthusiastic tutor. I travelled one day with a troop of eager scholars in a train from Haifa to Semakh ; they were all equipped with knapsack and water-flask, for they were bent upon a two days' excursion. They keenly followed the descriptions and identifications that came from the lips of their master as we traversed the picturesque Valley of Esdraelon, a buzz of comment following each successive explanation. We parted company at some station before Semakh, and I continued my journey to Tiberias. But early the next morning, as I was sailing in a launch along the wonderful blue waters of the Lake back to Semakh, I could see the troop of scholars marching along the shore in the distance, in rhythm with the spirited Hebrew song of which snatches were wafted across the Lake.

I saw a larger assembly of the children of Israel on another occasion. It was in the great hall of the Jaffa High School, known as the Herzl Gymnasium, which is not only the most conspicuous building in the Jewish township of Tel Aviv but also the nerve-centre of its life. I was taken there one evening and was told that I should see something unique, something one could not see in any other part of the world, only in a Jewish nationalist centre in Palestine. And, indeed, it was unique. It was an intellectual entertainment devoted to the life and teaching of Jeremiah the Prophet, in which the arts of designing and painting, of drama, poetry and song all played their particular parts. The whitewashed walls were decked with a most abundant and varied array of drawings and pictures illustrating the principal scenes in the career of the prophet. Paintings in oil or watercolour were few, for most of the designs were in quite different media-lentils ingeniously stuck upon paper and painted over, bits of coloured glass skilfully arranged, designs in fretwork, in cloth patches of motly hue and in 
276 THE JOURNAL OF A JEWISH TRAVELLER

dried flowers, all portraying the prophet of woe in some traditional pose-writing a scroll of sad tidings or hurling a stone upon the doomied city.

The audience was made up of men and women, as well as of the scholars of both sexes who had provided these novel decorations. A dark curtain concealed a platform from the humming and ever-shifting throng, which was divided into three classes according to the price they had paid for admission. A bell rang to warn us that the performance would soon begin; it rang again to bespeak order and silence; it rang a third time and the curtain rose. One of the teachers appeared on the platform and declaimed the story of the prophet in the prophet's words, his rich reverberating voice hushing the whole assembly into pensive silence, which was broken only by the applause that burst forth at the end of the recital. The curtain descended, and when it rose again upon the tinkling of the bell, we saw a wonderful living picture, a reproduction of Lilien's " By the Waters of Babylon," in impressive grouping, of which the outstanding figure was a beautiful damsel, with drooping head, mourning for Zion. The next scene presented Jeremiah, in a monologue, eloquent with self-accusation and denunciation, all pitched in a minor key ; and after an interval appeared the King, in sombre robe of royalty, bewailing the impending doom. Again the curtain fell, and when it rose once more it revealed the simple outlines of the solitary Tomb of Rachel, with a woman draped in black, wringing her hands, whilst from the rear came the doleful notes of a Hebrew dirge. And then followed a song in jubilant strains by a choir of boys and girls, "Is Ephraim unto me a precious son?" whose rich cadence swept across the hall and stirred deep memories of the glorious past, lifting the assembly to their feet in a storm of rapturous applause.

That unrehearsed spectacle was the most impressive of the evening. It lightened up in a flash the new intellectual life now dawning in Erez Israel. It was a consolation and compensation for so much that had yet to be done. 


\section{、}


, 


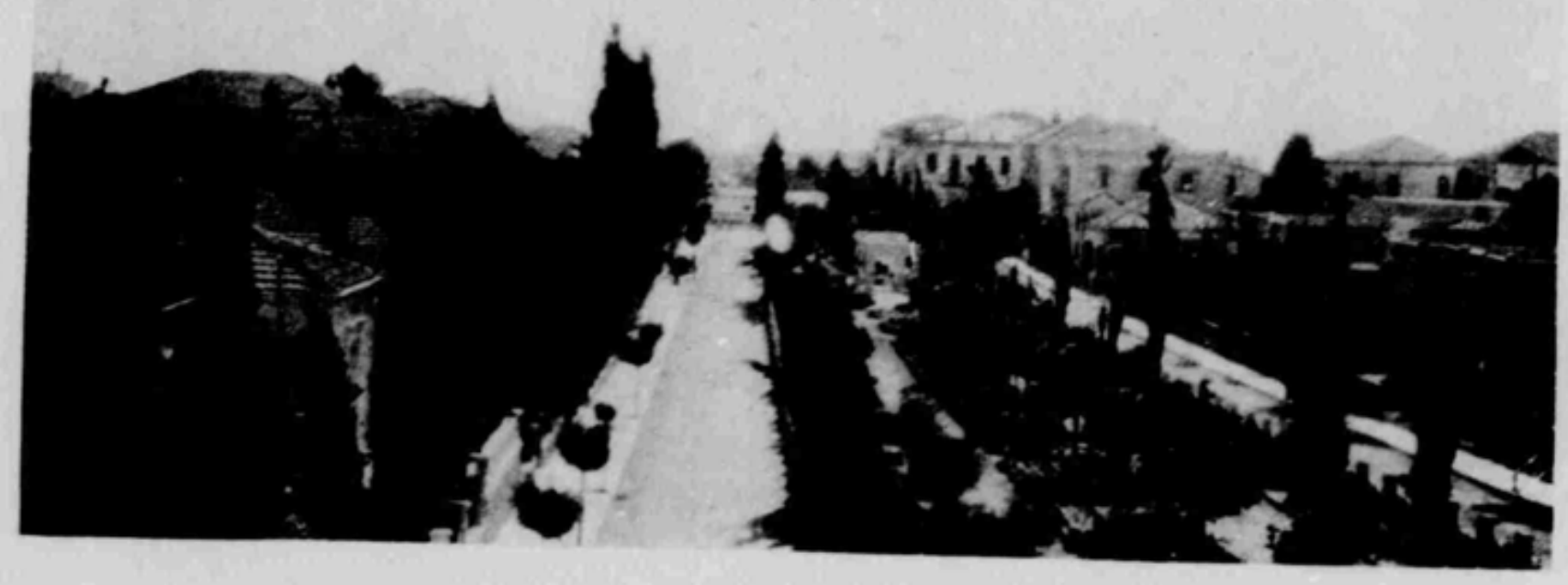

ROTHSCHILD AVENUE, TEL-AVIV

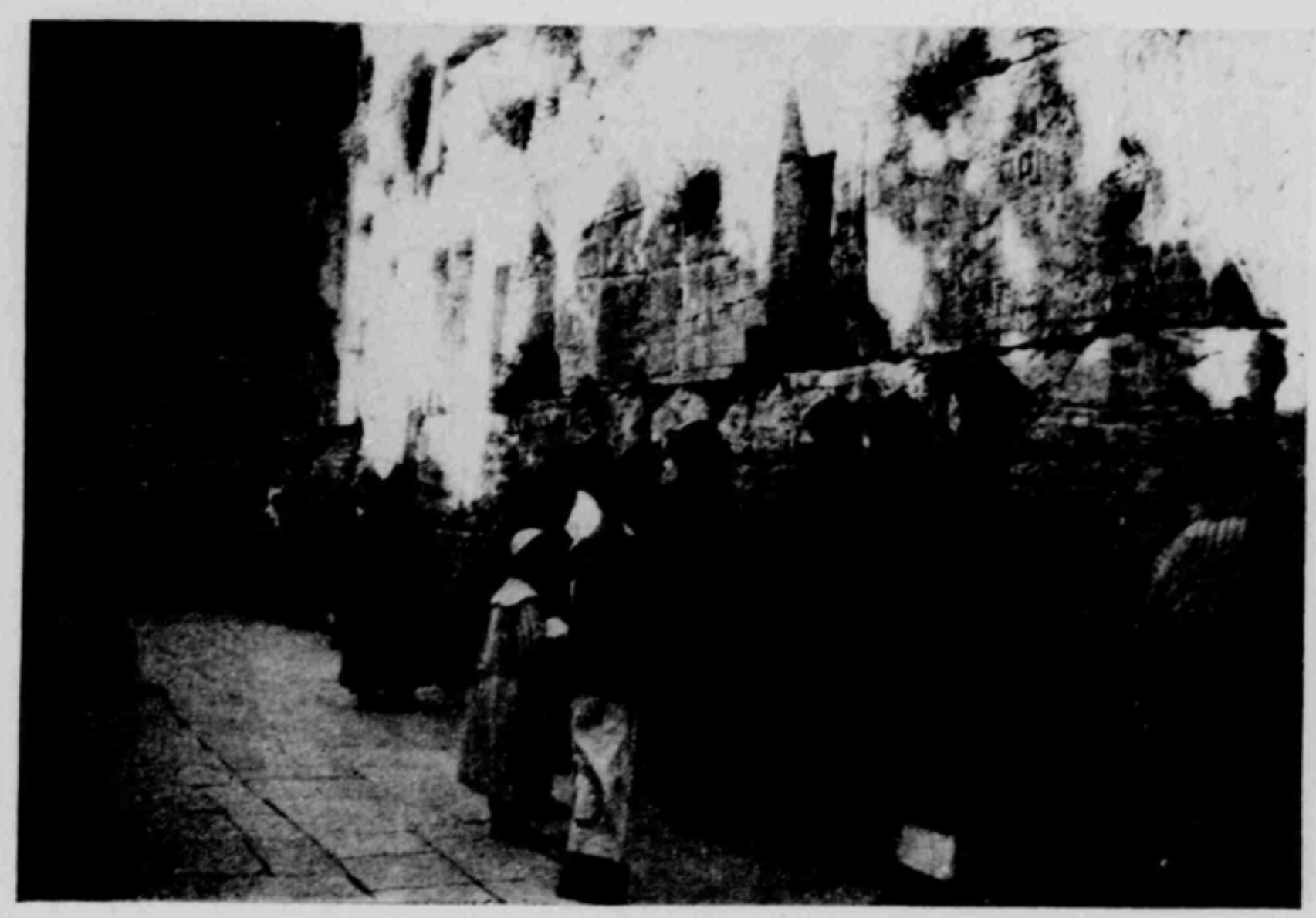

AT THE WESTERN WALL, JERUSALEM 
5

In the cafe of the Hotel Allenby-the Ritz of Jerusalem - where an orchestra discoursed lively music every afternoon, I heard a vigorous exchange of views and criticism. Some of the speakers were natives of Palestine, others were pioneers of thirty or forty years ago, others but recent arrivals from Europe or America who had come to seek openings for agricultural or industrial undertakings. All were united in pleasure at the British Mandate and at the presence of a Jew as head of the Government. But few were contented with the progress of things, though none gave utterance to despair or disappointment. What could one expect in nine brief months, especially at a time of such world-wide economic crisis? Some had indulged in beautiful dreams before they came, as though the mere fact of the British Mandate could work miracles and transform a desolate country overnight into an earthly paradise. Others spoke of the Zionist Commission as incompetent, as if its members, any more than their forefathers in Egypt thousands of years ago, could make bricks without straw. But the discerning realized that the glowing fancies by which they had been once inspired were woven of faith and hope, and that their materialization required-not charity, they scorned the idea-but national solidarity and generous sacrifice. Eastern Jewry had always been most passionate in its yearnings, but now that the day for their fulfilment had come, it found itself impoverished and impotent. Bruised, battered and almost decimated by a tornado of pogroms, it was able to sacrifice little else but itself. That was the tragedy. But what of the Western Jews, who had also prayed for nineteen centuries for the rebuilding of Zion, and who had lost but little in the war? When would they begin to make the great sacrifice? Upon their response rested not merely the salvation of Palestine, the fruition of centuries of glorious ideals and the redemption of the oppressed 
to-day, but the happiness of generations yet unborn and the opening up of a new chapter in the history of civilization.

Could all this be ? Were we not carried away by glowing phrases and perfervid emotions? An old colonist, grizzled and tanned, who had toiled for forty years in a neighbouring colony, shook his head in reproof. "When we began," he said, "we had countless difficulties -our ignorance of the land, our unfamiliarity with farming, the suspicion of our neighbours, the opposition of the authorities, the need of baksheesh, the malariabreeding swamps, our lack of machinery and of all kinds of convenience and comforts. But we plodded on. And now? Think of the forty and more flourishing colonies, which have grown up despite the antagonism of a corrupt and reactionary régime. Shall we not make much greater progress under the guidance, encouragement and protection of a liberal and enlightened Administration, and with a Jew as Governor? Money! Is that all ? God will help!" And he brushed the difficulty lightly aside as though money might rain down to-morrow like the manna of old.

But what of the Arabs? The question had remained unspoken until the last, but it seemed to offer little perplexity. " Have we not lived in peace and friendship with the Arabs for years ?" asked a planter of Rishonle-Zion. "Their whole agitation is based not upon our actual doings and strivings, but solely upon legends and slanders, upon stories that we wish to dispossess them and drive them out. The effendis are afraid of us, for they fear that their exploitation of the fellaheen will now be brought to an end, and so they stir up against us the victims of their own cupidity. Let us make clear our aims, point out the benefits we shall bring to the land and all its people, and prove there is room here for at least 4,000,000, and then the agitation will die out. But the Government must make a firm stand against our enemies, who are also its own enemies: they include 
agents of another Power who are only making trouble for themselves, and even officials of the Palestine Administration. The policy of the British Government, repeatedly and solemnly declared, is to establish a Jewish National Home in Palestine. All who are working against that are guilty of disloyalty, and should be restrained, punished or deported."

That was the dominant impression of all. Money from without, peace and goodwill within: with those few factors everything else would be possible, and the aspirations that first found utterance upon the conquest of Judea by the Emperor Titus and that had been reiterated and re-echoed endlessly ever since in every land, might yet find realization in our own day. But there was a section of Jewry who still placed little faith " in princes, in the sons of men." As their fathers had prayed through all the centuries of exile in their humble synagogues for the restoration of Zion, so they too believed that only through prayer and piety could the glorious end be won. And so they prayed, loudly and passionately, before the massive remnant of the ancient Temple wall, bedewing its grimy surface with their tears, and kissing its worn stones which shone for them with ethereal glory. To and fro they swayed and rocked, shaking their bent and aged bodies and gesticulating with outstretched hands, as though at the very footstool of the Divine Throne.

Yet among all that pious and palpitating throng there was not one of the youthful latter-day pioneers. A few were among the onlookers, curious and reverent, and one of them, with folded arms and pensive mien, was heard to say: "Let them pray! We have begun our work. But as long as they pray we know our work is not finished." 


\section{POSTSCRIPT}

WHRE years have passed since last I gazed upon the Temple wall, and in the interval, though the praying has not ceased, the labour

of restoring the country has been pursued with ever-increasing energy. Many are the developments that have taken place even before and since the ratification of the Palestine Mandate ; many are the deficiencies noted on my two visits that since have vanished. In the main the progress has been due to the influx of picked settlers and the reclaiming of the land. Chosen by virtue of physical fitness and technical ability, no less than for their zeal and devotion, from among the hosts throughout the world who have eagerly demanded admittance, some Io,000 workers have entered the country each year and been distributed to wheresoever their energies most were needed. The draining of marshes, the making of roads, the reafforesting of denuded hills, have proceeded apace. Large tracts of land have been bought and brought under cultivation. Many new farm-settlements have arisen, particularly in the Valley of Jezreel, where extensive areas, lying desolate and derelict for centuries, have been covered by smiling villages, humming with joyous activity. Settlers with means are also establishing themselves in the country in increasing numbers, and happily the relations between Jews and Arabs are perceptibly improving.

Life in the towns likewise presents an agreeable picture of beneficent development. Hundreds of houses have been built, new residential suburbs have been created, and various industrial establishments-factories, mills, workshops-have sprung into being. The founding of a Workers' Bank and of a Mortgage Bank has rendered available the credit needed for economic progress. The 
township of Tel-Aviv is now lighted by electricity, thanks to the perseverance of that genial but maligned engineer, Mr. Pinhas Rutenberg, whose greater scheme for harnessing the waters of the Jordan is at length on the eve of realization. An industrial exhibition held last spring at Tel-Aviv was a remarkable revelation even to the inhabitants of Palestine themselves. The question of a harbour is nearing decision, and the country is soon to have its own currency.

Moreover, schemes pertaining to the intellectual domain are also advancing. The Technical Institute at Haifa is now completed and open. The University of Jerusalem, thrust into the background for a time by more pressing tasks, will shortly be inaugurated as a research academy, pending the acquisition of the funds necessary for making it a teaching university. The Jewish National Library, whose cramped quarters cannot contain its daily increasing collection, is to be housed in a new building worthy of its exalted purpose. And apart from the growth of these public institutions, private enterprise has also helped to foster and forward the amenities of culture, especially in the allied realms of art and music. Exhibitions of local painters have become an annual event in the Tower of David, and Hebrew opera, which seemed such a distant fantasy when suggested to me by the Russian impresario at Semarang, has become an established feature in the social and intellectual life of the community.

There are still many problems-some political, others economic - that have to be solved, but slowly the Jewish National Home, that vague yet pregnant concept, without precedent or parallel, is being built up by the children of Israel in the land of their fathers. Slowly the dream of centuries, the vision that illumined the gloom of the Ghetto, the ideal that assuaged the sufferings of persecution, is taking shape and substance, in the hallowed phrase of Israel's liturgy, " in our own days." 


\section{INDEX}

Acre, 267-8

Actors, Yiddish, 124, 132-4

Adelaide, 44-6

Aden, 266

Agra, 247-9

Alexander, Michael Solomon, I45

Alexandria, 3,12

Allenby, Lord, 69, 89

Alston, Sir Beilby, r9r

Altson, Mr. B. H., 5I, 52

Anesaki, Prof., 152

Anglo-Jewish Association, I I9,26I

Arabic, II8, 204, 205, 223, 245

Arabs, at Ludd, Io; in Jerusalem, 14 ; plantations of, 18 ; belief in charms, 23 ; relations with Jews, 278

Argentina, Jewish farmsteads in, 18

Ashkenazim, 204-5, 207

Atonement, Day of, 59, 96, r57, I99, 226, 228

Auckland, 66-70

Audja, River, 20

Australia, soldiers of, 23, 24, 37

Austrians, 163, I84

Bagdad, II7, II8, I21, 129, I98, 201

Balfour Declaration, I6, 62, 139, I70, 178

Balfour, Lord, 16

Ballarat, 52, 97-8

Bandoeng, 213-14

Basrah, 26r

Batavia, 209-12

Beaconsfield, 98

Bearsted, Lord, 226

Bedouins, 26

Belilios, Hon. E. R., I19

Bene-Israel, 250, 255-62

Bernstein, Rev. I. A., 44

Bezalel School, I5

Blashki, Mr. Aaron, 93

Bohemia, 5

Bols, General, 23, 63
Bolsheviks, in Russia, 95, 137 ; as sailors, 154; in Siberia, I61. $172,173,176$; in Russian Turkestan, 263

Bolshevism, 48, I42, I45, I62, 170

Bombay, 108, 250-65

Bookmakers, 93-4, 227

Boryslav, 69

Boxer Riots, 186

Bradford, Lady, I45

Brisbane, 99-104

British-Israelites, 6I $-2,89$, Ior, 153,158

Buechler, Dr. A., 136

Buechler, Mr. W., 136

Budapest, rзo

Buddhas, 225

Buddhist Temples, I50, $\mathbf{I}_{52}$

Bundists, $159,169,187$

Buitenzorg, 220

Cabbala, 125

Cairo, 9, 12

Calcutta, II7, 23I-46

Cameron, Rev. Dr. A., 83

Canea, 228

Canton, $\mathrm{II7}$

Cape Guardafui, 30

Carnegie, 16

Carpathians, 5

Castleberg family, 87-8

Cecil, Lord (Robert), 36

Celebes, 106

Ceram, ro6

Ceylon, 30

Changchun, 160

Chassidim, I7I

Chesterfield, Lady, 145

Chesterton, Mr., 25

China, 252

Chinese Eastern Railway, r6r, 167

Chita, 169, I71, I75

Christchurch, $8 \mathrm{I}-3$

Clubs, in Wellington, 85 ; in Hongkong, 116, 120; in Shanghai, 132 ; in Singapore, 207 
Cochin Jews, 148, 241, 257, 262

Cocos Islands, 31

Coddrington, Miss, 197

Coen, Jan Petersen, 212

Cohen, Mr. A. J., 223 seq.

Cohen, Rev E. M. D., 231 seq.

Cohen, Rabbi Francis L., 60, 64

Cohen, Mr. George J., 63, 64

Cohen, Mr. Henry E., 59

Cohen, Mr. John J., 59

Cohen, Sir Lewis, 45

Cohen, Hon. Mark, 78

Cohen, Shalom David, 232

Colombo, 30-1, 32, 44

Colonies, agricultural, 18

Cracow, 7, 50

Crete, 227

Cyprus, 196

Czecho-Slovaks, 164

Czechs, 5

Danglow, Rev. Jacob, 53-4

David, Professor, 6I

David, Sir Sassoon, 253

David, Tower of, 281

Davidson, Sir Walter, 63

Day of Atonement, 59, 96, 157, 199

Dead Sea, 14

Delhi, 249-50

Dietrich, Mr. Max, 184

Dilb, 270-1

Disraeli, Benjamin, 80, 145

Djemal Pasha, 22, 23, 107

Drisin, Mr., 171

Dunedin, 83-4

Egypt, 9, ro, 29, 107, 184

Eisenberg, Mr., 26-7

Ekma, 207-8, 223, 229, 231

Eliot, Sir Chas., 148

Esdraelon, Valley of, 275

Etham, 29

Eucalyptus, plantations in Palestine, 20

Evseroff, Mr., 176, 180

Ezekiel, Mr. E. M., 260

Ezekiel, Samuel, 257

Ezra, Mr. David, 234

Ezra, Mr. Edward (Hongkong), II7, 118

Ezra, Mr. Edward I. (Shanghai), 128-30

Ezra, Mr. N. E. B., 124, 13r

Ezra, Mr. E. D. J. (Calcutta), 233, 239
Far Eastern Republic, 163, 170

Fenwick, Sir G., 83

Fiji Islands, 8I

Fleishman, Mr., 227

Football, in Palestine, 26

Forester, Rev. O. St. M., 145-6

Fraser, Sir Everard, 130

Freedman, Rabbi D. I., 33, 37, 39, 40

Fremantle, 32-3

Friend, Mr. J. L., 124

Fusan, $155-6$

Galicia, 4, 53, 69, 184

Galuth, 13,108

Gawler, Colonel, 46

Gaza, 9

Gechthoff, Leonid, 218

Geddes, Prof. P., 252-3, 266

Geelong, 52, 96-7

Gershevich, Mr., 186

Ghetto, 8, 269, 272, 28I

"Glaxo," 77

Goldberg, Mr. Boris, 142

Goldberg, Mr. Isaac, 142

Goldberg, Mr. Solomon, 142, 143

Goldfaden, Abraham, 133, 219

Goldman brothers, 137

Goldreich, Mr. S., 98

Goldstein, Rabbi, 70

Gordon, Hon. Mrs. E. A., 15I-4

Gordon, Mr. S., 86, 88

Gordon Memorial Hall, 183, 185-6

Graetz, 51

Green, Mr. Sol., 93

Greenberg, Mr. L. J., 151, 153

Gubbay, Mr. David, I17, I18, 119

Gubbay, Mr. Elias S., 233

Gubbay, Mr. Ezekiel A., 232, 234 , 237-8, 241 seq.

Gunson, Mr. J. H., 68

Haifa, 18, 89, 90, 272 ; Technical Institute, 274, 281

Halsted, Mr. E. I., 84

Halukah, 8, 15

Haluzim, 4, 55, 269-70

Harbin, 100, 154-5, 158, 160-81, I91

Hatikvah, 5, 100, 102, 103, 104 , $186,25 \mathrm{I}$

Hebrew, names and newspapers, 15 ; study of, 53 ; books, 130; as living tongue, 268-9

Hebrew University, 16, 17. Also under University 
Herskowitz, Mr., r57, 182

Hertzbergs, roo

Herzl, stamps of, 6 ; postcard of, 153

High Commissioner (of Palestine), 153

Hill, Sir John Gray, 17

Hindustani, 232

Hirsch, Rabbi W., I 15 , 126, 128-9

Holland, 6 ; Jews of, 2 IO-II, 220

Hongkong, 103, II 5-2I

Hughes, Rt. Hon. W. M., 56

Hunt, Mr. Horace, 68

Huxham, Hon. J., 99

Intermarriage in Australia, 4I ; in New Zealand, 81 ; in China, 130 ; in Japan, 138 ; in Java, 212,215 ; in Burma, 226

International Sleeping Car Co., I6o

Isaacs, Henry, 67

Isaacs, Justice, 52-3

Islington, Lord, 70

Israel's Messenger, I3I

Jacob, Ezekiel Judah, 233

Jaffa, 18, 19, 21, 22, 272

Jaffa Gate, 12

Japan Advertiser, $\mathrm{r}_{4} \mathrm{I}$

Japan Chronicle, I50

Japan Gazette, $\mathbf{I}_{4} \mathrm{I}$

Jerusalem, ancient city, 12 seq.; University of, 37,55 ; high school, I19; Rabbis of, I2I

Jewish National Fund, $6,203,27 x$

Jewish National Home, 29, 36 . $267,273,279,28$ r

Jewish National Library, 16,274 , 28I

Jews' College (London), 33, 54, 60

Jezreel, Valley of, 280

Joint Distribution Committee, I4I

Jordan, waters of, 272,281

Kadoorie, Sir Ellis, I I9

Kadoorie, Mr. E. S., II7, I32

Kai-Feng-Fu, Jews of, I18, 126, I52, 197

Kagan, Mr., 177, 180

Kalgoorlie, 42

Kantara, 9

Kashgar, 126

Kaufmann, Dr., 176, 191

Keesing, Mr. Maurice, 70, 87

Kerr, Mr. (Tientsin), I83, I86

Kisselhoff, Rabbi, 178
Kobe, r36-40, ${ }_{54}$

Koltchak, I6r, 166, 176

Kyoto, I 50-3 $^{-3}$

Labberton, Dr. van Hinloopen, 211

Lauder, Harry, 96-7

Lawson, Mr. John, 40

Lazar, John, 45

League of Nations, 273

Lemberg, 4, 5, 6

Lenin, 147

Levin, Rabbi, $x 71$

Levy, Hon. Daniel, 59, 61, 63, 94, 95

Library, Jewish National, I6

Lichtenstein, Dr., 2 ro

Lichtenstein, Arnoldson and Paykel, 68

Lilien, E. M., 276

Lloyd, Sir George, 252

Lobingier, Judge, I30

Louisson, Hon. Chas., 78

Lubman, Mr. David, 22-3, 25

Ludd, 10, 18, 269, 270

Lyons, Sir Joseph, 123

Mackesy, Col. C. E. R., 69

Maimonides, Moses, 264

Malaria, suppression of, 20

Malay Peninsula, 197

Malbim, 208

Manchester Grammar School, 77

Manchuria, 156, 16r, 167

Mandate for Palestine, 268, 273, 277,281

Manila, 108-14, 120

Manila Times, 112

Malkicedec Bonami, 236

Maoris, 72-5

Marathi, 258

Marannos, 263

Marks, Mr. Percy J., 65

Marks, Hon. Henry, 8I

Masel, Mr. E., 40

Massey, Right Hon. W. F., 79-80, 89

Masterton, 85,87

Mediterranean, 4, 9

Melbourne, 47-57

Melchior Treub, 209, 220

Menasseh, Mr. Ezekiel, 207-8

Mesa, Mr., 266

Meshed, Jews of, 262-4

Meshullochim, I2I

Mesopotamia, I19, 121, 124, 204

Messiah, 67, 101, 108, 202 


\section{Yexdco, 195}

Meyer, Mr. Menasseh, $190 \mathrm{seq}$.

Meyer, Mr. Meyer, 222

Meyerovitch, Mr., 25

Millions Club, 60

Milner, Lord, 79, 109

Miners, Jewish, 69

Minyan, 157, 200-1

Missionaries, 145-6, 196-7

Mitsukoshi store, 149

M'Master, Alderman, I0I

Moeraki, 89

Moiseiwitsch, Mr. Benno, 40, 64

Moguls, 248-9

Moji, 136

Monash, Sir John, 50-2

Mond, Sir Alfred, 36, 56, 109

Mongolian Desert, 122, 123

Montefiore, Jacob, 45, 58

Montefiore, Joseph, 58

Montefiore, Sir Moses, 45

Morning Post, 48, 235

Moses, Dr. E., 250, 259

Moslems, 263

Mosque of Aksa, '12

Mosque of Omar, 12

Mount Carmel, 90, 270

Mount of Olives, 14 $_{4} 269$

Mount Scopus, 16

Mount Sinai, 195-6

Mount Tarawera, 7I

Mukden, 156-9, 182

Murison, Sir William, 204

Museum, Natural History (Jerusalem), 16

Myers, Sir Arthur, 68, 82

Myers, Mr. M., 78

Nagasaki, I17, 130, 136

Nanking, 119,127

Nathan, Mr. Alfred, 66

Nathan, Mr. David, 66

Nathan, Mrs. David, 70

Nathan, Mr. Joseph, 77

Nathan, Sir Matthew, 56, 100, 115

Nationality, questions of, 52-3, $184,25^{8}$

Nebi Musa, 267

Nes-Zionah, 25

Nestorian monument, 15I-2

Newcastle (N.S.W.), 98-9

New Year, 88, 228

New Zealand, soldiers of, 69

North China Star, 183

Nullabor Plain, 43

Opera, Hebrew, 28I
Operatic company, $217 \mathrm{seq}$.

Oranges, cultivation in Palestine, 20

Orontes, 28, 33

Otago Times, 78, 82, 83

Pagoda, Schwedagon, 224

Pale of Settlement, 162

Palestine Restoration Fund, 146, 173, 237

Parkes, Sir Henry, 59

Parliament, in Melbourne, 56 ; in Sydney, 59, 95 ; in Wellington; 74,89

Passports, 5, 7

Patiala, Maharajah of, 264

Peace Conference, 29, 35, 36, 53

Pechter, Mr.,S., 65

Peking, 130

Peking Post, 192

Penang, 207-8

Persia, Jews of, 260, 262-4

Perth, 34-4I, 42

Petach-Tikvah, 19-22, 270

Pharaoh, 29

Philistines, 9

Phillips, Mr. David, 84

Phillips, P. A., 67

Pilcher, Mr. G., 235

Pinsk, 7

Plassy, 196

Plunket nursing system, 70

Pogroms, in Lemberg, 4,5 ; in Eastern Europe, 36, 64, 181, 184,187

Poland, 4; Jews of, 69, 75

Poles, 5, 53

Porter, Mr. (Harbin), 117, 178, 179

Port Said, 28, 30, 173

Prague, 172

Pressburg, 5

Prince of Wales, 45, 74, 153, 254

Prisoners-of-war, 163, 166, 172, 173, 177, 191

Pysacki, Professor, 151

Rafa, 9

Rahabi, David, 256

Reading, Lord, 226, 254, 266

Red Sea, 29-30, 266

Regine, Mr. L. S., 192

Rehoboth, 26-7, 173, 270

Reuben, Miss E., 262

Reuter, 103

Rickard, Sir Arthur, 6I

Riley, Bishop, 44

Rimutaka Gorge, 86, 88, 229 
Rishon-le-Zion, 22-5, 55, 75, 278 Rome, 12

Rothschild, Baron Edmond de, 20

Rothschild Hospital, I5

Rothschild, Lord, 36, I09

Rothschilds, 63, II7

Rotorua, 70, 72, 75

Ruhleben Camp, 68, 217

Russia, Jews of, $34,47,48,76$, I0O, I10, I12, I20, I22, I24, I25, 129,137

Rutenberg, P., 282

Salomons, Sir Julian, 59

Samson, 9

Samuel, Sir Herbert, 36, 46, 53 , $63,97,109,226$

Samuel, Sir Marcus, 226

Samuels, Sir Saul, 59

San Francisco, I4I

San Remo decision, 128, 174, 267-8

Sassoons, II7, I25, I98, 232, 253

Sassoon, David, II7

Sassoon, David, and Co., II7, I3I, 232

Sassoon, E. D., and Co., II7, 232

Sassoon, Capt. E. V., 253

Sassoon, Sir Edward, II8

Sassoon, Sir Jacob, II8, I3I

Sayers, Mr., 216

Scrolls of Law, II8-I9, 201

Seeligson, Mr. Louis, 38

Semakh, 275

Semarang, 216-19, 28I

Semenoff, I66

Seoul, 156

Sephardic Jews, II8, 124, 200

Shahmoon, Mr. E., r3I

Shanghai, 100, 116, 120, 121, 12234,175

Shellim, Mr. D., 250 seq.

Shepparton, 55, 98

Shimonoseki, $1_{54}, I_{55}, I_{5} 6$

Shippers, 232

Siam, Court of, 203 ; King of, 222

Siberia, 100, 122, 125, I30, I4I, $164,168,186,189,218$

Silverberg, Mr., I57

Sinai Desert, 9

Singapore, 108, 120, 121, 197-207, 227

Skidelsky, Mr. S., I78

Smith, Mr. McCallum, 39

Socialism, 142

Sokolow, Mr. N., 36

Solomon Islands, 227
Solomon, Pools of, 270

Solomon, Mr. M. J., 44

Solomon, Mr. Saul, K.C., 84

Solomon, Mr. Sassoon E., 225

Solomon, Mr. Sassoon J., 125, 126, 128

Solomon, Hon. V. C., 45

Soskin, Mr. Isaac, $178, \mathbf{1} 8 \mathrm{r}$

Soskin, Dr. S., 178

Sourabaya, 214-16, 221

South Sea Islands, 196

Soviets, 161,176

Spitzer, General, 228

Stout, Sir Robert, 79

Straus, Dr. Leo, 216 seq.

Stubbs, Sir R., I20

Suez Canal, 28-9, 266

Sumatra, 209, 221, 227

Sungarei River, I64

Suva, 8I

Sydney, 58-65, 91-5

Syles, Sir M., I49

Synagogues, in Jerusalem, I2; at Rishon-le-Zion, 22 ; in Melbourne, 53 ; in Sydney, 62 ; in Hongkong, 110, $118-20$; in Shanghai, 125, 127; in Nagasaki, 136 ; in Harbin, $17 x$; in Singapore, $198-9,200-x$; in Rangoon, 225 ; in Calcutta, 232 seq. $j$ in Meshed, 263

Taj-Mahal, 7I, 248-9

Talmud, 124, 203

Tango Maru, 103, 105, 108, II5

Tanin, Moise, 107

Tartar City, 190

Tasmania, 81

Tattersall's Club, 93

Tel-Aviv, 10, 19, 102, 275

Temple, 13, 219, 249, 279, 280

Temple of Heaven, $192-4$

Territorialism, 170

Teschen, 5

Tetragrammaton, 199, 234

Theatre, Yiddish, 132 ; Japanese, I49

Theomin, Mr. D., 84

Thursday Island, 106

Tiberias, 18, 82, 275

Tientsin, $1_{58}, x_{59}, x_{75}, 1_{82-8}$

Tippoo Sahib, 257

Titus, 279

Tokyo, 147-50

Toledano, Mr. T., I3I

Tolkowsky, Mr. W., 250

Tomb of Rachel, 276 
Townsville, 105

Tram ticket, 255

Tribes, the lost Ten, 67, I01, 151, 256

Trieste, 3, 5, 7, 173

Trocadero, 123

Trotsky, 147

Tsuruga, I4I, 154

Tulkeram, agricultural school at, II9

Turkestan, 126

Turks, indifferent to improvements, 20 ; fiscal system, 27

Ukraine, 187, 269

Ukrainians, 53

Ungern-Sternberg, Baron, 176

United States, Jewish farmsteads in, 19

University, Hebrew (of Jerusalem), $16,37,55,61,252,274$, 28I

Urga, 176, 19x

Viceroy (Jewish), 226, 240

Victoria, Queen, 152

Vienna, 6

Visas, 6

Vladivostok, 140, 154, 155,168 , $169,173,175,177,191$

Vogel, Sir Julius, 80, 82

Wady-el-Hanin, 25

Wailing Wall. See Western Wall

War, Great, 36, 98

Wars in India, 257

Warsaw, 7, 75, 124
Watchmen, in Jewish colonies, 21, 25

Wedgwood; Col. J. C., 224

Weigall, Sir Archibald, 45

Weizmann, Dr., 36

Wellington, 76-80

Wellington Evening Post, 77

Weltevreden, 210 seq.

Western Wall, 13

Whakarewarewa, 72

Whangpoo, 123

Wilson, President, 177

Wolf, Mr. Lucien, 83

Wolffsohn, David, 86

Wolfson, Col. J. N., 108-14

Wong, Joseph, 125-6

Woosung, 123

Wren, Mr. Jack, 44

Wright, Mr. R. A., 80

Yabroff, Mr., 137, 154

Yangtze-kiang, 123

Yemenites, 259

Yiddish, 132, 143, 159, 170, 174, $187,203,217$

Yokohama, II7, 140-7; Jewish Benevolent Society, 206

Yoshiwara, 149

Zamboanga, 107

Zeltner, Mr. M., 50

Zichron Jacob, 2I5

Zion, praying for, $15,38,187,277$, 279

Zionist Commission, 24

Zionist Executive, 16

Zionist flags, 34, 35, 103, 154, 186 


\section{Demy 8vo. pp. ix+251. 108. 6d. net}

\section{THE RUHLEBEN \\ PRISON CAMP}

BY

ISRAEL COHEN

\section{With 29 Illustrations and a Plan}

\section{EXTRACTS FROM SELECTED PRESS REVIEWS.}

"The work is wonderfully full of facts, and touches the life of the camp at many points with the practised hand of a journalist, trained to observe and report."-Times.

"It is the most moving and the most comprehensive story of Ruhleben that has appeared -a memorial of British stamina and of German arrogance which will remain for the enlightenment of our children's children."-rorksbire Post.

“Mr. Cohen's book, full of excellent photographs, and written with great fairness and good humour, is worthy to rank as the standard record of life at this famous camp."-Star.

"This is by far the fullest and most interesting account of the great internment camp on the banks of the Spree in which all British civilians of military age in the German Empire have been concentrated. . . . This book will have a permanent value as a treasury of wellarranged facts."-Morning Post.

"The strength of a case gains greatly if it is presented dispassionately, and Mr. Israel Cohen's damnatory record of Prison Life at Ruhleben is ten times the more effective by virtue of the calm, judicial spirit in which it is unrolled."-Daily Telegrapb.

"An"invaluable and permanent addition to the literature about prisoners of war." - $-\mathcal{F} e w i s b$ Cbrọicle.

"His unimpassioned record may claim to possess the value of a historic document." Glasgow Herald.

"He has written a sober and comprehensive history which will survive as a permanent document of the war when the brilliant sketches are, perhaps, forgotten."-Saturday Reviero.

"With his marvellous eye for detail and his insight into German character, Mr. Cohen was well equipped for his task; he has done it very conscientiously, carefully avoiding exaggeration and invective, and the result is intensely interesting."-Country Life.

"Perhaps the sanest, most temperate and fair-minded account we have had of the life in the notorious Ruhleben Prison Camp."-Bookman.

" He writes withcut bitterness and, to all appearances, without allowing his critical faculty to become blunted by his troubles."-Westminster Gazette.

" Mr. Cohen's book will be read with great interest from cover to cover." - The Bystander.

"He has written the best book on Ruhleben that has yet been published : no other volume gives 80 full an account of the life and tone of the camp nor 80 clear a picture of its composite elements."-Birmingbam Daily. Post.

"His vivid and entertaining volume."-Western Mail.

METHUEN \& CO., LTD., 36 Essex Street, London, W.C. 2 
Demy 8vo. pp. xiv +874. 128. 6d. net

\section{JEWISH LIFE \\ IN MODERN TIMES}

BY

ISRAEL COHEN

In One Volume, with 12 Illustrations and a Map

\section{EXTRACTS FROM SELECTED PRESS REVIEWS.}

"An extensive review of Modern Judaism, ambitious in its plan, by an able writer."-Tbe Times.

"The most compact and comprehensive work of its kind in existence, a treasury of facts and figures which should be in the hands of every student of the Jewish problem."-Tbe Nation (Mr. Israel Zangwill).

"Mr. Cohen's book is the best attempt of the kind that exists. . . . It is encyclopsedic . . a book with a theris."-Daily Nezos.

"The work of a publicist impelled to a labour of love."-Atbenaum.

"A wonderfully complete survey of the question." -Sunday Cbronicle.

"The volume will take rank as an authoritative record of facts, inferences, and opinions connected with a subject of universal interest."-Glasgoro Herald.

"It is well informed, well written, and interesting throughout." - studies.

"The best up-to-date work on the subject of the modern Jew-combining attractiveness and echolarship." -Irisb Cburcb Quarterly.

"He possesses the pen of a ready writer, and he tells his story with knowledge, warmth, and oympathy." - Hibbert fournal.

"He has achieved a notable success." - Fewisb Cbronicle.

“Mr. Israel Cohen's book is an admirable piece of work, which almost completely anowers any question on the Jewish race of the present day which an intelligent reader could fairly demand from him. It is written in a terse and distinguished style."-Nero rork Times.

"We venture to bespeak for his book a creditable place in the contemporary literature of Israel."-Literary Digest.

"This stands out conspicuously in the group of recent accounts of modern Judaism, both for its comprehensiveness and its analytic detail."-Outlook (New York).

"To say simply that he has succeeded would be to give him faint praise, unless we understand fully the difficulties with which he has had to cope." $r$ ale Reviero.

"A notable contribution to the literature of Jewish life and thought."-Menorab Fourmal.

"Its merits are very great, and for a long time to come Mr. Cohen's book will stand as the best account that has hitherto been given of perhaps the most interesting figure of modern life."-American Hebrew.

METHUEN \& CO., LTD., 36 Essex Stregt, LoNdon, W.C. 2 
"The most thrilling volume of the year."-Daily Mail.

\section{Some Experiences of a New Guinea Resident Magistrate}

By CAPT. C. A. W. MONCKTON, F.R.G.S., F.Z.S., F.R.A.I.

Wüh numerous Illustrations. Fifth Edition. Demy 8vo. \$1 1s. Od. net.

"Captain Monckton has a lively pen. He has enjoyed his life among savages . . . and his book is written with the zest of a schoolboy . . . a frank and cheerful book." -Robrrt LYND, in the Daily Nezos.

"Mr. Monckton has written a boys' book for men. In it something happens on every page. . . . It is a long book, though not a page too long."-Times Literary Supplement.

"A book of entrancing interest for boys and their fathers. It is a plain and a true one, and is stranger than fiction. The most remarkable book of travel and exploration since Stanley's 'Darkest Africa.' "-Daily Mail.

\section{Last Days in New Guinea}

Being Further Experiences of a New Guinea Magistrate

By CAPT. C. A. W. MONCKTON

Illustrated. Second Edition. Demy 8vo. 18s. net.

"One cannot think or wish for a more readable book of exploration and travel."-Morning Post.

"A most interesting and amusing book. We are glad to have the continuance of his adventures in a new book which is not-less absorbing than the first."-Spectator.

JOHN LANE THE BODLEY HEAD LTD., VIGO ST., W. I 


\section{A Tenderfoot in Colorado}

By R. B. TOWNSHEND

$A$ racy and interesting adventure in the Far West

Illustrated. Demy 8vo. 103. 6d. net.

Evening Standard.- " Here is raw. stuff of half a dozen boys' story books; yarns that bring back the thrill that we used to get out of Fenimore Cooper and Mayne Reid and Bret Harte: memories of the time when the Red Man really was a menace to the pioneer."

Daily Mail.- "An excellent account of Mr. Townshend's experiences in the West when it was really ' wild and woolly.' There are plenty of experiences in this lively book. The picture of the West in those days with its free, out-of-door life, is not an unattractive one."

Daily Tele, raph. - "Many crowded hours of glorious life."

New Witness.-"I have never read 2 better book about the Colorado country or one more admirably written."

\section{TheTenderfoot in New Mexico}

\section{By R. B. TOWNSHEND}

Illustrated. Demy 8vo. 12s. 6d. net.

Sunday Times.-"There is a charm about Mr. Townshend's sketches of wild life which makes him the intellectual comrade of Dana and 0 . Henry."

\section{Wild African Animals I Have Known}

By H.R.H. PRINCE WILLIAM OF SWEDEN

Illustrated with about 200 Nature Photographs of Wild Animals. Demy Ato. \&1 5n. net.

The feature of this book is over 200 photographs taken under the direction of Prince Wilhelm himself.

In spite of the many photographs of wild African animals that have appeared, those in this book stand out as a series apart, for, as a big game hunter, the Prince knows these wild animals and their ways even better than the professional naturalists, and, consequently, the photographs possess an interest which far outweigh any of the same kind which have appeared previously.

New Statesman.- "We have never before seen such photographs of the wild animals of Central Africa. They are far more enlightening and fascinating than hundreds of skins and tusks."

JOHN LANE THE BODLEY HEAD LTD., VIGO ST., W. . 


\section{Adventures in Bolivia}

By C. H. PRODGERS

Illustrated with sketches in colour by the Author, and with photographs. With an Introduction by R. B. CUNNINGHAME GRAHAM.

Second Edition. Demy 8vo. 12s. 6d. net.

An account of expeditions in search of Inca treasure said to have been hidden by the Jesuits, and rubber concessions in an almost unknown part of Bolivia. Told with the naiveté and directness of a man who has done things.

Daily Mail. - "Perilous journeys, strange native life, and the beautiful birds, flowers and butterfiles haunting deep tropical forests are described very delightfully in this book."

\section{Adventures in Peru}

By C. H. PRODGERS

Author of Adventures in Bolivia. Illustrated from the author's original sketches and photographs.

Demy 8vo. 12s. 6d. net.

\section{The Adventures of a Tropical} Tramp

BY HARRY L, FOSTER

Illustrated. Demy svo. 12s. 6d. net.

South American life from a new angle. One of those rare books of travel $-\mathrm{a}$ record of experiences that is fresh, vivid, and interesting.

Westminster Gazette. - "A striking series of adventures."

Daily Neros. - "An amusing, vivid story, with shrewd reflections on men and manners."

\section{My Journey Round the World}

By the late LORD NORTHCLIFFE

Edited by Cecil and St. John Harmsworth. With portrait and map.

Demy 8vo. 128. 6d. net. Third Edition.

Outlook. - "Here at last is the real Lord Northcliffe, the man himself speaking to us, with all his defects and charming qualities, his greatness and his weakness, appearing on every page. The great charm of this book is that in it one of the leading propagandists of this age tells us the unvarnished truth as he sees it, and incidentally throws a new light on his own limited but powerful personality."

JOHN LANE THE BODLEY HEAD LTD., VIGO ST., W. I 


\section{Arabella in Africa}

By Sir FRANK SWETTENHAM, G.C.M.G. Author of "Unaddressed Letters," "Also and Perhaps," etc.

With pictures by REX WHISTLER and MARY FORSTER-

KNIGHT, and sketch-map. Crown 8vo. 8s. 6d. net.

An amusing, cleverly-written account of a motor tour in North Africa, full of incident and colour, and containing incidentally much useful information for the intending traveller.

\section{Two Vagabonds in the Balkans}

By JAN GORDON and CORA J. GORDON Authors of "Poor Folk in Spain," etc. With twelve illustrations in colour and many in black and white by the authors. Royal 8vo. 12s. 6d. net.

Another delightful travel-book by the authors of "Poor Folk in Spain" and "Misadventures with a Donkey," this time about a journey in Bosnia and Servia, with characteristic illustrations.

\section{A Gringo in Mañana Land}

BY HARRY L. FOSTER

Author of "The Adventures of a Tropical Tramp," "A Beachcomber in the Orient," etc. Illustrated. Demy 8vo. 12s. 6d. net.

A racy and amusing account of adventures, revolutions, and hairbreadth escapes in Mexico, Guatemala, Salvador, Honduras and Nicaragua.

\section{In the Footsteps of Livingstone}

Being the Diaries and Travel Notes made by

\section{ALFRED DOLMAN}

Edited by John IRving, and illustrated by the author.

Demy 8vo. 12s. 6d. net

This interesting diary, which has just come to light, contains narratives of big game shooting in Africa and the conditions of that country from 1840 to 1848 , when the writer (who was a personal friend of Moffat, Livingstone, and Mrs. Livingstone) met an untimely death at the age of twenty-four.

JOHN LANE THE BODLEY HEAD LTD., VIGO ST., W. I 


\section{Chinese Lanterns}

By. GRACE THOMPSON SETON

Author of $A$ Woman Tenderfoot in Egypt, etc.

\section{Illustrated. Demy 8vo. 12s. 6d. net.}

In this book the well-known traveller-author and wife of the famous naturalist describes her many unique experiences in China, her meetings with presidents and premiers, her dangerous and exciting adventures with bandits and in revolutions, and her extraordinarily interesting observations on the education and aspirations of the Chinese women.

\section{A Woman Tenderfoot in Egypt}

\section{BY GRACE THOMPSON SETON}

Author of $A$ Woman Tenderfoot, Nimrod's Wife, etc.

With over forty Illustrations. Demy 8vo. 12s. 6d. net.

A Womare Tenderfoot in Egypt is a happy combination of intimate human stories and accurate facts. The lure of ancient Egypt, land of the Pharaohs, is contrasted with a modern Egypt struggling to throw off the shackles of the past. The story Mrs. Seton tells is of an enticing, alluring land of romance where, because they cannot trust the ever-changing sands, men's keen eyes have been trained to follow the path of the stars. Especially appealing is the vivid portrayal of the efforts of the Egyptian women, hedged in by custom and ancient laws, to secure the freedom enjoyed by European women.

\section{A Land of Opportunities By E. J. STUART \\ Illustrated. Demy 8vo. 10s. 6d. net.}

A fully illustrated account of the author's recent expedition of exploration in the Northern Territory of Australia.

\section{A Woman's Impressions of German}

\section{New Guinea By LILIAN OVERELL}

\section{Illustrated. Demy 8vo. 12s. 6d. net.}

"There was little that the writer of this unconventional book missed in these strangely primitive islands. . . Her book is strewn with picturesque anecdotes and odd little yarns. The book gives a vivid enough picture of these far-away islands, and the illustrations are abundant and well chosen."

Sunday Times.

\section{Siwa: The Oasis of Jupiter Ammon By C. DALRYMPLE BELGRAVE}

With an introduction by SiR Reginald WINGATB, G.C.B. Illustrated in colour from the author's original drawings, and from photographs.

\section{Demy 8vo. 158. net.}

A description of this wonderful and little-known desert town with its unique rock dwellings, and an account of the habits of its people.

JOHN LANE THE BODLEY HEAD LTD., VIGO ST., W. I 


\section{Unconducted Wanderers}

By ROSITA FORBES

Demy 8vo. With over 7o Illustrations from Photographs by the Author and others. 12s. 6d. net.

An extremely amusing and unconventional account of travel in the Malay States, the South Seas, China, etc., with the interest and attraction of a first-rate novel.

Evening Standard.- "Those in search of the perfect companion for 2 lazy afternoon in a hammock will find their wants admirably supplied by 'Unconducted Wanderers.' Their adventures are retailed with an unfailing humorous touch, and the scenery and occupants of these far foreign strands are painted in descriptive language, which is always vivid and at times beautiful."

\section{Poor Folk in Spain}

\section{BY JAN AND CORA GORDON}

Foolscap 4to. With coloured frontispiece and 46 Illustra-

tions in black and white by the authors. 12s. $6 \mathrm{~d}$. net.

Spectator. - "Authors of travel books are like travelling companions, and should be chosen for the same qualities: The authors of 'Poor Folk in Spain,' who are both artists and have illustrated their book themselves, have the right qualities for their task. Their book is as good as a holiday."

\section{Madrid}

By. MRS. STEUART ERSKINE

Crown 8vo. With numerous illustrations in half-tone.

78. 6d. net.

Observer.- "For a capital within two days of London, Madrid is singularly little known. Mrs. Steuart Erskine's 'Madrid,' past and present, is perhaps as useful an introduction as one could find to its history, its artistic interests, and the outlines of its contemporary life."

\section{Spanish Galicia}

By AUBREY F. G. BELL

Illustrated. Author of "The Magic of Spain,"

"In Portugal," etc. 7s. 6 d. net.

Morning Post.- " Mr. Bell has written something far more precious than a guide book. There are admirable descriptions, which remain fixed in the memory."

JOHN LANE THE BODLEY HEAD LTD., VIGO ST., W. I.

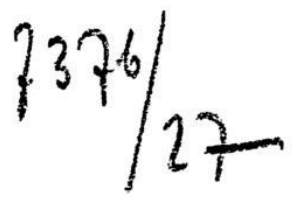



